\title{
MODIFICACÃO OBJETIVA DA DEMANDA NO PROCESSO CIVIL
}

Dissertação apresentada a Banca Examinadora do Programa de Pós-Graduação em Direito, da Faculdade de Direito da Universidade de São Paulo, como exigência parcial para a obtenção do título de Mestre em Direito, na área de concentração em Direito Processual, sob a orientação do Prof. Titular Dr. José Roberto dos Santos Bedaque.

UNIVERSIDADE DE SÃO PAULO

FACULDADE DE DIRETO

SÃO PAULO-SP

2014 
BANCA EXAMINADORA:

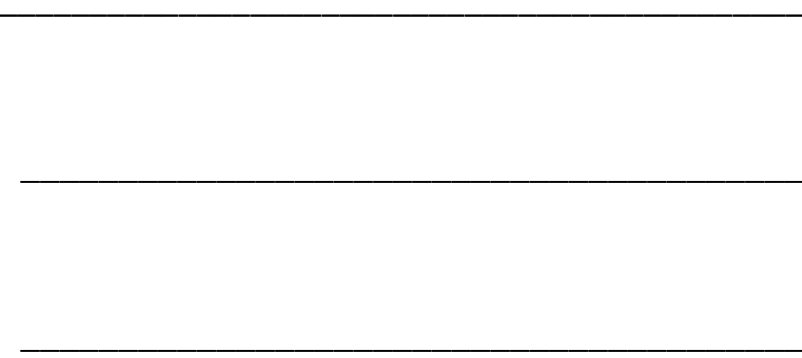


Ao Tín, sempre

Alla Shiprt, faleminderit për gjithçka 


\section{AGRADECIMENTOS}

Agradecer a todos que contribuíram para que esse trabalho se concretizasse, sem dúvida alguma, é uma tarefa impossível. Entretanto, não mencionar alguns, por outro lado, seria no mínimo ingratidão.

Por essa razão, antes de tudo, agradeço a Deus por tudo.

Agradeço também ao Professor José Roberto dos Santos Bedaque, que, mais do que me confiar uma vaga no mestrado sob sua orientação, fez despertar em mim o interesse pelo processo e pela vida acadêmica. Foram sete anos de ensinamentos que, mais que um profissional, formaram alguém extremamente interessado por esse ramo do direito.

Da mesma maneira, gostaria de dirigir minhas palavras de gratidão ao Professor Michele Taruffo, um dos maiores filósofos com quem tive o prazer de conviver. Antes mesmo de viajar, já me inspirava com suas reflexões. Abrindo as portas de seu gabinete junto à Universidade de Pavia durante cinco meses, deu todas as condições para que essa simples dissertação pudesse nascer e se desenvolver. Sem ele certamente o trabalho não teria tomado o rumo que tomou. Gostaria de agradecer, outrossim, à Dottoressa Cinzia Gamba, que me recepcionou com extrema atenção e dedicação em sua Universidade. Proporcionou-me reflexões sobre o tema escolhido e colaborou com a coleta de material. Meu muito obrigado.

Agradeço, igualmente, aos Professores Ricardo de Barros Leonel e Heitor Sica, que, com muita atenção, foram precisos em suas críticas durante a banca de qualificação. Seus apontamentos naquele momento foram fundamentais para que o trabalho tomasse o rumo correto. À Professora Susana Henriques da Costa, meu muito obrigado pelas indicações de textos e pelas ponderações. Ao professor José Rogério Cruz e Tucci, pela cultura jurídica e inspiração.

Agradeço, ademais, à minha família. À minha mãe, pelo carinho e atenção de sempre. Ao meu pai, pela força, pela ajuda e pelo suporte de todos esses anos. Aos meus irmãos, por existirem.

Agradecer a todos os amigos seria inviável. Por isso, o faço em nome de Felipe do Amaral Matos, Larissa Tunala Gaspar, Carlos Roberto Bonaretti Filho, Lia Carolina Batista Cintra e Anne Yuri Kano, que, direta ou indiretamente, colaboraram para o resultado final dessa 
dissertação. A todos os demais que não foram citados, mas que contribuíram para o desenvolvimento dessa dissertação, muito obrigado. 


\section{RESUMO}

RIGUETTI, Gabriel Felipe Roqueto. Modificação Objetiva da Demanda no Processo Civil. Dissertação (Mestrado em Direto) - Faculdade de Direito da Universidade de São Paulo, São Paulo, 2014.

O tema da modificação dos enunciados fático e jurídicos ao longo do processo é objeto de debate por parte da doutrina e da jurisprudência por mais de um século. Contudo, não obstante os vários esforços dos estudiosos, o tema ainda oferece muitas controvérsias. $\mathrm{O}$ método identificativo da demanda utilizado pela doutrina clássica parece não oferecer respostas satisfatórias aos problemas práticos. Nesse sentido, o presente trabalho buscará, por meio de uma visão epistemológica dos fatos e do direito, dar novos contornos ao instituto modificativo, interpretando-o como instrumento de atribuição de qualidade ao conjunto representativo formulado pelas partes e, com isso, igualmente, aumentar a qualidade da sentença. 


\section{RIASSUNTO}

RIGUETTI, Gabriel Felipe Roqueto. Modificazione Oggettiva della Domanda nel Processo Civile. Dissertazione (Master in Giurisprudenza) - Facoltà di Giurisprudenza dell'Università di Sao Paolo, São Paulo, 2014.

Il tema della modificazione dei enunciati fattici e giuridici nel corso del processo è oggetto di discussione nella dottrina e nella giurisprudenza da più di un secolo. Tuttavia, nonnostante i vari sforzi degli studiosi, il tema ancora offre molte controversie. Il metodo identificativo della domanda che viene utilizzato dalla dottrina classica sembra, comunque, non offrire risposte soddisfacenti ai problemi pratici.In questo senso, il presente lavoro cercherà, tramite una visione epistemologica dei fatti e del diritto, dare nuovi profili all'istituto modificativo, interpretandolo come strumento di attribuzione di qualità all'insieme rappresentativo formulato dalle parti e, con questo, altresì, alzando il livello della sentenza. 


\section{$\underline{\text { ÍNDICE }}$}

INTRODUÇÃO 3

1. A MODIFICAÇÃO DA DEMANDA E SUA ABORDAGEM ATUAL ……................................ 7

1.1. A teoria da individualição da demanda pelos três elementos ..................................................... 8

1.2. A teoria da identificação do objeto litigioso do processo (Streitgegenstand) ………............... 19

1.3. O embate substanciação x individuação e a modificação da demanda ................................... 33

1.4. Demandas heterodeterminadas $x$ autodeterminadas e a modificação .................................... 36

1.5. Conclusões parciais .......................................................................................................... 39

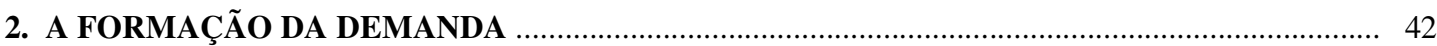

2.1. Considerações Iniciais - Retomada de Conclusões ................................................................ 42

2.2. A demanda revisitada - nova perspectiva de abordagem ..................................................... 46

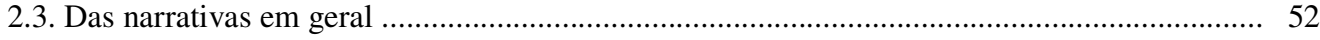

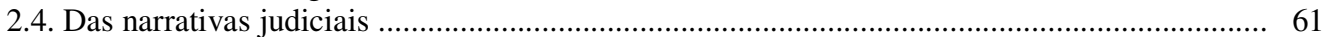

2.4.1. Das construções dos enunciados fáticos ................................................................ 62

2.4.1.1. Da incompletude e parcialidade dos fatos trazidos com o ato introdutório .. 68

2.4.1.2. O fato e sua complexidade ………………………………………….... 75

2.4.1.3. O fato e sua relevância .............................................................................. 91

2.5. Dos enunciados de direito ............................................................................................ 107

2.6. Da formação dos pedidos ....................................................................................... 113

2.7. Conclusões parciais ....................................................................................................... 127

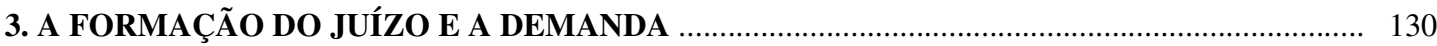

3.1. Critérios para uma decisão justa ………………………………………………………...... 131

3.2. A visão silogística da decisão ..................................................................................... 139

3.3. O juízo de fato .......................................................................................................... 144

3.3.1. Knowledge in flux e a formação da premissa de fato ........................................... 152

3.4. O juízo de direito - a individuação da norma ....................................................................... 158

3.5. O princípio dispositivo, o princípio da correlação e suas dimensões ..................................... 163

\section{A MODIFICAÇÃO DA DEMANDA - PROPOSTA DE NOVOS CONTORNOS PARA UM} INSTITUTO

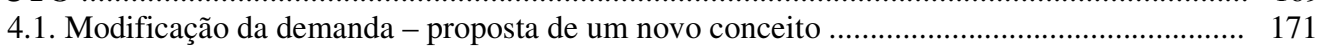

4.2. Proposta de releitura do instituto - uma nova função .......................................................... 176

4.2.1. A modificação da demanda, a verdade e a complexidade dos enunciados representativos ........................................................................................................... 180

4.2.2. A modificação da demanda, a dialética entre as partes e o justo procedimento .... 185 4.2.3. A modificação da demanda e a correta aplicação da lei ...................................... 190

4.3. Instituto modificativo e seus limites propostos ............................................................ 192

5. A MODIFICAÇÃO DA DEMANDA NO ORDENAMENTO POSTO ........................................ 198

5.1. O procedimento comum ............................................................................................... 198

5.1.1. O procedimento comum no Código de 1939 .................................................... 198

5.1.2. O procedimento do Código de 1973 ........................................................................ 200

5.1.3. O procedimento comum do Anteprojeto .......................................................... 203

5.2. O processo Coletivo .............................................................................................. 205

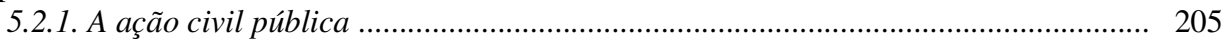

5.2.2. A ação popular .................................................................................................... 206

5.2.3. A Ação de improbidade administrativa .......................................................... 207

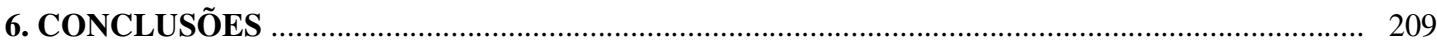

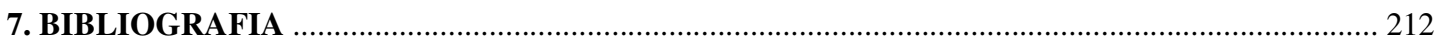




\section{INTRODUÇÃO}

O processo civil tem passado por diversas mudanças. Entretanto, alterações no decurso de seu desenvolvimento não são recentes, podendo o estudioso dessa área do direito encontrar as mais diversas sinuosidades em sua linha de evolução.

Assim, aquele que se debruça sobre obras históricas dedicadas ao processo encontra variados níveis de liberdade, seguidos de outros tantos momentos de rigidez das formas.

Contudo, a ciência processual, a despeito das notáveis marchas e contramarchas, teve uma crescente evolução. ${ }^{1}$

Dessa maneira, o processo, em épocas remotas, passou por momentos de obscurantismo, impregnado por elementos religiosos e pautado por um caráter simbólico. Não se fazia distinção entre direito processual e material.

Aos poucos, foram-se delimitando os conceitos de sua ciência, chegando a um exacerbado formalismo para justificar sua autonomia. ${ }^{2}$ Nele, a preocupação maior de seus teóricos era a afirmação do próprio processo como ciência autônoma. Em outras palavras, buscou-se definir os institutos processuais, delinear seus conceitos, fixar seus princípios. Enfim, visavam seus pensadores a fazer a nítida separação entre direito material e direito processual $^{3}$, fato que reforçou as formalidades como condão de legitimação do processo.

Inegável a importância dessa fase da vida processual, momento que pode ser apontado como nascedouro desse ramo da ciência jurídica e principal fase de amadurecimento de seus elementos intrínsecos.

\footnotetext{
${ }^{1}$ Essa também é a opinião de AlVARO DE OLIVEIRA, para quem “(...) o fio histórico da questão aponta a um ciclo ascendente, helicoidal, de evolução”, Do Formalismo no Processo Civil - proposta de um formalismovalorativo, São Paulo, 2010, p. 33.

${ }^{2}$ É por isso que se fala em fase autonomista do processo. Para melhor compreensão desse período BüLow, La teoría de las excepciones y los presupuestos procesales, Miguel Angel Rosas Lichtschein (trad.), Buenos Aires, 1964.

${ }^{3} \mathrm{Na}$ obra de BüLOW a busca pela diferenciação entre relação jurídica processual e material é latente, podendo-se até mesmo afirmar ser o núcleo central dos estudos, bem como demonstra o trecho a seguir transcrito: “(...) que el proceso es uma relación de derechos y obligaciones recíprocos, es decir, uma relación jurídica. Esta simples, pero, para el derecho científico, realidad importantíssima, desde todo punto de vista, no há sido hasta ahora debidamente pareciada ni siquiera claramente entendida. Se acostumbra a hablar, tan solo, de relaciones de derecho privado. A ésta, sin embargo, no puede ser referido el proceso", ibidem, p. 1.
} 
Entretanto, pode-se afirmar que a fase autonomista, mesmo cumprindo seu importante papel, chegou ao fim. Não se justifica mais um estudo processual sem um olhar crítico para elementos contidos fora dele. Seus efeitos, seus reflexos e sua influência na vida dos indivíduos devem ganhar notoriedade, ficando para trás a visão meramente endoprocessual.

Dessa maneira, chega-se à fase atual, baseada na ótica instrumentalista do fenômeno processual. No atual momento dessa ciência jurídica, os valores passam a aproximar novamente processo e direito material, relativizando esse binômio. Não se trata de um retrocesso científico, mas da reinterpretação dos pólos identificando uma função do segundo na atuação do primeiro.

Assim, tem-se atualmente a concepção de processo como instrumento para efetivação de um direito previsto no plano material. Tendo o Estado vedado a autotutela, teve ele que dispor de um meio para que aqueles que tivessem seus direitos subjetivos lesados pudessem reivindicar por eles. Este meio é o processo.

Destarte, diante dessa nova visão, pode-se concluir que a ciência processual deve se preocupar com elementos externos a ela. $\mathrm{O}$ resultado conseguido pelo instrumento passa a ser fundamental para seus pensadores.

Diante dessa visão, a efetividade processual ganha destaque, passando a ser um objetivo importantíssimo a ser alcançado

Logo, qualquer estudo atual sobre direito processual deve, segundo quem escreve, ser norteado pela sua natureza instrumental, sob pena de revelar-se, ao final, algo inútil e desinteressante. Suas estruturas, instituições e conceitos devem ser encarados sob a perspectiva do objetivo do processo, qual seja: por em prática as regras de direito material gerando a pacificação social. ${ }^{4}$

A ciência processual, tomada por esse ângulo, apresenta-se, pois, como meio em busca da consecução de um fim. Daí se extrai que uma visão teleológica do processo deve

\footnotetext{
${ }^{4}$ Já no prefácio de sua obra, CÂNDIDO RANGEL DINAMARCO afirma: "Este estudo pretendeu ser uma síntese das novas tendências metodológicas representadas pela bandeira da efetividade do processo, pelo destaque ao seu caráter instrumental e pela exaltação de sua missão perante a sociedade - e não mais apenas perante o direito material, como se acreditava antes”, A Instrumentalidade do Processo, São Paulo, 2009, p. 13.
} 
ser imperativamente adotada, seja para aplicação de suas regras no plano concreto, seja para a estruturação de qualquer estudo que se proponha a debater temas desse ramo. ${ }^{5}$

Por essa ótica, muito útil será a revisitação de temas antigos por meio de visões diferenciadas, tudo para possibilitar que a aplicação do direito material se dê de forma célere, justa e, conseqüentemente, efetiva ${ }^{6}$.

Nesse sentido, importante será tracejar breves linhas sobre como a doutrina em geral tem tratado o tema da modificação da demanda. O presente trabalho, dadas suas limitações naturais, deverá abordar de maneira sucinta as principais linhas de raciocínio que guiaram os debates até hoje, enumerando suas principais características - sem a pretensão, por óbvio, de exaurir seus conteúdos.

Tal exposição tem como objetivo demonstrar e explicar em quais termos a questão hoje se coloca. Isto é, a leitura histórica do instituto modificativo servirá como embasamento teórico para o entendimento dos problemas existentes e para que seja possível formular críticas que embasarão a proposta de solução.

Superada essa etapa, passará a ser realizado um estudo por uma ótica interdisciplinar dos fatos e dos direitos na esfera processual, colocando à luz elementos até então deixados de lado pela perspectiva preponderante. Como se verá, há características fundamentais dos elementos objetivos da demanda que impedem que eles sejam tomados como conceitos analiticamente definidos e prontos já com o ato introdutório do autor e contestatório do réu.

Ver-se-á que o enclausuramento dos fatos e dos pedidos é incompatível com a natureza do conjunto representativo da crise formulado pelas partes.

\footnotetext{
5 DinAmARCO, com a clareza que lhe é peculiar, assim afirma: "A tomada de consciência teleológica, incluindo especificação de todos os objetivos visados e do modo como se interagem, constitui peça importantíssima no quadro instrumentalista do processo: sem compreender sua instrumentalidade assim integralmente e apoiada nessas colunas, não se estaria dando a ela a condição de verdadeira premissa metodológica, nem seria possível extrair dela quaisquer consequiências cientificamente úteis ou aptas a propiciar a melhoria do serviço jurisdicional”, ibidem, p. 177-178.

6 "Pode-se dizer, pois, que o direito processual é a ciência que tem por escopo a construção de um método adequado à verificação sobre a existência de um direito afirmado, para conferir tutela jurisdicional àquelas situações da vida efetivamente amparadas pelo ordenamento material. Trata-se de visão do direito processual preocupada com seus resultados e com a aptidão do instrumento para alcançar seus fins". E finaliza: "Na concepção de direito processual não se pode prescindir do direito material, sob pena de transformar aquela ciência num desinteressante sistema de formalidades e prazos" Cf. José RoBERTO DOS SANTOS BEDAQUE, Direito e processo - influência do direito material sobre o processo. $4^{\mathrm{a}}$ ed. São Paulo: Malheiros, 2006, p. 14.
} 
Em seguida, entrar-se-á na questão da formação do juízo por parte do julgador. Como se poderá constatar, também esse procedimento construtivo não é algo estático, mas compreende uma série de passos complexos até que se atinjam os seus resultados, as decisões.

Em momento subseqüente, cotejando os elementos adquiridos com os raciocínios anteriores, se proporá um sistema legal no qual o instituto da modificação da demanda ganhará uma nova função: a de atribuição de qualidade à decisão, abandonando-se a visão privatista e patológica da atividade modificativa.

Em seguida, o presente trabalho trará tópico dedicado exclusivamente aos sistemas positivos nacionais, comparando-se a estrutura abstrata proposta àquelas existentes. Nesse capítulo, alguns comentários serão tecidos frente ao que disporá o novo $\mathrm{CPC}$, tomando-se para isso o anteprojeto apresentado pelo Senado e suas alterações. Aqui, buscar-se-á fazer um cotejo das atuais disposições e as proposições feitas pela comissão de juristas para o novo diploma processual, visando sempre a encontrar as eventuais conseqüências práticas da aplicabilidade da modificação na busca da efetividade processual.

Ao final, far-se-á um breve balanço de toda a análise, verificando qual a melhor técnica para se atingir os escopos do processo.

Esse é, em suma, o itinerário que será seguido. 


\section{A MODIFICAÇÃO DA DEMANDA E SUA ABORDAGEM ATUAL}

Todo trabalho que pretenda enfrentar um tema de maneira científica deve, antes de tudo, avaliar em que ponto e em quais termos o problema relativo a ele vem sendo tratado pelos estudiosos anteriores. Uma retrospectiva histórica, mais que uma mera reprodução do que já fora dito, é fundamental para que se reconheçam os avanços até então alcançados e para que se busque, por meio de uma visão crítica dos textos e fontes, avançar ainda mais em direção a melhoras e a aperfeiçoamentos quanto aos pontos ainda problemáticos.

Se assim é em âmbito geral, também o será para o ramo processual do direito, em especial no que tange à modificação da demanda, argumento bastante tormentoso que há anos vem chamando a atenção dos processualistas e, cada vez mais, parece longe de ter uma solução homogênea e satisfatória.

Por essa razão, buscar-se-á trazer aqui uma visão panorâmica dos diversos posicionamentos doutrinários, expondo as críticas a que foram submetidos e tracejando algumas outras ulteriores de cunho próprio, almejando, ao final, fazer um balancete dos pontos positivos a que se chegou.

Para iniciar, acredita-se ser fundamental fixar um ponto de partida. Não seria interessante, tampouco produtivo para o momento, começar uma abordagem do tema da modificação da demanda partindo-se de tempos imemoriais. Primeiro pela simples razão de que o autor, por limitações individuais e temporais, nada teria a acrescentar ao que até então já foi escrito. Ao contrário, diante da profundidade e da qualidade das obras produzidas até então, o hipotético retroceder aos tempos romanos, por exemplo, seria mera reprodução superficial e pálida daqueles autores, o que em nada acrescentaria para a comunidade jurídica. Desse modo, preferível remeter ao leitor aos grandes historiadores do processo civil, vez que ali poderá encontrar uma pesquisa ampla e com uma gama bibliográfica bastante vasta. ${ }^{7}$

\footnotetext{
${ }^{7}$ Duas obras na literatura jurídica nacional chamam a atenção pela profundidade, amplitude e qualidade da pesquisa histórica. São elas: CRUZ E TUCCI, A causa petendi no processo civil brasileiro, São Paulo, 2001, pp. 29 e ss., passando pelo direito visigótico, comum e hispano-lusitano (pp. 47 e ss.); e SiCA, Preclusão processual civil, São Paulo, 2008, pp. 6 e ss., destacando-se para o tema, em especial, pp. 23 e ss. Para o tema específico da modificação da demanda na literatura estrangeira, em obra recente, MARIACARLA GIORGETTI, Il principio di variabilità nell'oggetto del giudizio, Turim, 2008, pp. 47 e ss.
} 
Somado às razões acima, há ainda o fato de que a ciência processual atual, no que se refere ao tema em debate, desenvolve suas abordagens partindo de premissas e usando perspectivas oriundas de duas grandes matrizes do pensamento: uma advinda da escola alemã, que visa a encarar a modificação da demanda individualizando o Streitgegenstand, e outra muito influenciada pela escola italiana de processo, que enfrenta o argumento por meio da identificação da demanda. Logo, são os problemas dessas linhas de pensamento e seus nós teóricos que impactam diretamente o quotidiano dos operadores do direito.

Desse modo, enfrentar os principais pensadores de ambas as escolas parece ser o ponto de partida ideal para a reflexão que aqui se busca desenvolver. ${ }^{8}$

O presente capítulo, portanto, será dividido em quatro partes: a primeira dedicada aos pensadores peninsulares, partindo-se de CHIOVENDA até os escritos mais recentes; a segunda tendo como foco a escola alemã do objeto do processo; a terceira encarando as polêmicas mais conhecidas sobre o tema; e, por último, finalizando-se com uma pequena conclusão parcial sobre as reflexões mais importantes e fixando as premissas para o desenvolvimento do trabalho.

\subsection{A teoria da individualização da demanda pelos três elementos}

A doutrina e a jurisprudência brasileiras, no que tange ao objeto da modificação da demanda, têm, em grande parte, sido guiadas pelas linhas mestras da teoria da identificação da ação pelos seus três elementos: causa de pedir, pedido e partes.

Embora tenha suas origens no direito antigo, tal pensamento teve as raízes de sua teorização, da maneira como concebemos hoje, dada por um jurista italiano: GIUSEPPE ChiovendA ${ }^{9}$. Foi ele quem estruturou a teoria da identificação da demanda e deu a ela os contornos conhecidos - e muito usados - hodiernamente.

Falar da teoria chiovendiana em termos constantes e homogêneos, todavia, parece ser algo equivocado. Conforme se nota durante a evolução do seu pensamento, os três

\footnotetext{
${ }^{8}$ Apresentando mais razões para se tomar o estudo desse ponto, CANOVA, La domanda giudiziale e il suo contenuto, in Commentario al c.p.c. diretto da E. Allorio, livro II, tomo I, Torino, 1980, pp. 11-15.

${ }^{9}$ Apontam para isso GRASSO, La regola della corrispondenza tra il chiesto e il pronunciato e le nullità da 'ultra' o da 'extrapetizione', in Riv. dir. proc., 1965, pp. 387 e ss., e CANOVA, La domanda, cit. p. 15.
} 
elementos identificadores, embora tenham sido sempre o substrato de seus posicionamentos e de suas definições, não seguiram uma articulação permanente entre eles durante toda sua obra. ${ }^{10}$

Em seus escritos iniciais, CHIOVENDA põe destaque sobre aspectos processuais da causa, relegando a um segundo plano o direito material feito valer. $\mathrm{O}$ citado autor tratava tais elementos identificadores, em especial os ditos objetivos, como institutos distintos e autônomos uns dos outros ${ }^{11}$. A causa de pedir e o pedido, não obstante ambos fossem responsáveis por identificar a demanda proposta, eram enxergados como entidades independentes. Essa visão é chamada vertente dualística da teoria chiovendiana.

Tal secção entre os dois institutos causava impactos diretos no que se referia à modificação da demanda. Para essa perspectiva de análise, bastava a alteração de um único elemento, mesmo que o outro se mantivesse incólume, para que a demanda original fosse descaracterizada. Em outros termos, uma simples modificação do pedido, ainda que a causa petendi fosse integralmente mantida nos moldes originais propostos, daria origem a uma demanda diferente da primeira. $\mathrm{O}$ mesmo aconteceria se a causa de pedir tivesse seus limites alterados, mesmo que o pedido se mantivesse nos exatos termos iniciais.

Se a elaboração de CHIOVENDA quanto ao pedido teve poucas alterações ao longo dos anos, o qual, segundo suas afirmações, é composto pelo provimento requerido ao juiz (pedido imediato) e pelo bem da vida em disputa (pedido mediato), a causa petendi, dentro de sua própria obra, apresentou-se como ambígua e fonte de revisões. ${ }^{12}$

Inicialmente, alegou ser a causa de pedir um fato jurídico. Contudo, não especificou se essa definição abarcava os fatos, entendidos como acontecimentos históricos alegados pelo autor, ou se a referência era tão somente à fattispecie normativa positiva. Tal dúvida, no que tange à identificação da ação, gerava controvérsias no sentido de que, caso somente os acontecimentos naturalísticos é que compusessem o instituto, então a juridicidade era medida pela tutela jurisdicional pleiteada. Por outro lado, se a causa petendi fosse formada

${ }^{10}$ CANOva, op.ult.loc.cit.; CINZIA GAMBA, Domande senza risposta. Studi sulla modificazione della domanda nel processo civile, Padova, 2008, p. 7.

${ }^{11}$ Identificazione delle azioni. Sulla regola 'ne eat iudex ultra petita partium', in Saggi di diritto processuale civile, v. I, Milão, 1993, pp. 157-177; ID., Principios de derecho procesal civil, Jose Casáis y Santaló (trad.), tomo II, Madri, 1925, pp. 55 e ss., 77 e ss..

${ }^{12}$ Sobre os pedidos, ChIOvenda, Principios, cit., p. 73. Para as críticas, CANOvA, La domanda, cit. p. 16; GAMBA, Domande, cit. p. 8; HeINITZ, I limiti oggettivi della cosa giudicata, Padova, 1937, pp. 147 e ss.. 
pelo suporte fático normativo, a juridicidade adviria da referência a uma relação jurídica correspondente a um específico paradigma normativo. ${ }^{13}$

Em momento sucessivo, CHIOVENDA, com o intuito de clarear as coisas, mantendo a coerência com as premissas que embasavam toda a sua obra - em especial sua teoria concreta da ação e sua visão sobre a função da jurisdição -, conceituou a causa de pedir como sendo a existência de uma concreta vontade de atuação da lei e os fatos dos quais surge o interesse de agir. ${ }^{14}$

Nesse sentido, nota-se que, em uma ação condenatória, por exemplo, fundada em um contrato - fonte de uma obrigação inadimplida-, o fato constitutivo, representado pela celebração do negócio jurídico e o não cumprimento do acordado, somado à vontade do autor em atuar a lei referente às obrigações civis, comporiam a causa petendi do autor.

Desse modo, colocado o problema das ações concorrentes, em que se toma como análise a responsabilidade aquiliana e a responsabilidade contratual em um acidente de trânsito, CHIOvEnDA afirma tratar-se, segundo o conceito de causa de pedir exposto, de uma só ação. Há, segundo ele, o mesmo fato (acidente), a mesma responsabilidade de reparação dos danos causados e, portanto, a mesma demanda. A variação da fonte da obrigação (ato ilícito ou contrato) não alteraria em nada o contexto inicial. A re-propositura em caso de improcedência, pela lógica, estaria vedada. ${ }^{15}$

A coerência do raciocínio, porém, se perde quando se tenta aplicá-lo ao caso das ações constitutivas negativas. Em demandas dessa espécie, a causa de pedir seria formada pela afirmação de um direito potestativo e pelo fato que lhe deu origem. Entretanto, confrontado se o elemento identificativo era composto pelo evento naturalístico constitutivo do direito ou pela fattispecie normativa, CHIOVENDA acaba por romper a lógica anterior.

\footnotetext{
${ }^{13}$ Canova, La domanda, cit. p. 17; Gamba, Domande, cit. p. 8; HeInITIZ, Considerazioni attuali sui limiti oggettivi del giudicato, in Giur. It., 1955, parte I, p. 757.

${ }^{14}$ Chiovenda, Principios, cit., p. 74; CANOVA, La domanda, cit. p. 17.

${ }^{15}$ ChIOvenda, Identificazione delle azioni, cit., p. 168-169. Em suas palavras: "Tale è il caso dell'apparente concorso ad. es. dell'azione aquiliana colle azioni contrattuali, quando purê il vincolo obbligatorio importi diverse responsabilità (responsabiltà per colpa o senza colpa; culpa levis in abstracto o in concreto), L'azione è qui uma sola; essa tende al risarcimento dei danni ed ha per causa il fatto danoso: questo può essere qualificato dal vincolo contrattuale, ma la responsabilità è una sola, quella derivante dal fatto qualificato, e non può perseguirsi con due sucessivi giudizii, sol perchè uno si affermi la qualifica, nell' altro no".
} 
Foi-lhe proposto o problema dos vícios do consentimento, nos quais os fatos eram os mesmos, a vontade da concreta aplicação da lei também (desconstituir o negócio jurídico), mas com a alteração da fattispecie (dolo, erro, coação etc.). Para esse caso, o autor italiano afirmou que não haveria identidade entre as ações. Uma eventual improcedência de uma demanda fundada no fato $\mathrm{X}$ e qualificada como dolo, não seria a mesma que uma ulterior ação fundada no mesmo fato $\mathrm{X}$, mas entendida como erro.

Como é perceptível, a conceituação de causa de pedir como sendo o fato constitutivo mais a atuação concreta da lei, no que se refere às ações constitutivas negativas, se mostra insuficiente. ${ }^{16}$

A lógica interna da teoria chiovendiana sucumbe, outrossim, quando testada nas ações declaratória negativas. Nessa espécie, o autor da demanda não traz um fato constitutivo de seu direito. Tampouco demonstra uma vontade concreta de aplicação da lei. Em regra, o que ele faz é justamente o contrário: ele afirma uma inexistência dessa vontade legal. Assim, o autor poderia afirmar como fundamentação de sua pretensão o que bem entendesse sem que isso implicasse em alteração da ação, pois a inexistência do direito seria sempre a mesma ${ }^{17}$. Em caso de improcedência, o autor não poderia re-propor a demanda, pois a inexistência já teria sido refutada.

A parte a inversão do sentido do critério, que antes era positivo (vontade da lei) e agora passa a ser negativo (ausência dessa vontade), salta aos olhos a disparidade de tratamento existente entre réu e autor ${ }^{18}$. A inversão dos pólos da ação causa um desequilíbrio enorme entre os litigantes. No caso, se o indivíduo propusesse uma demanda declaratória positiva e essa fosse julgada improcedente, poderia ele alterar seus fundamentos e estaria afastada a coincidência. Bastaria que o novo autor trouxesse uma nova razão para que pudesse reformular o pedido de existência ou validade da mesma relação jurídica ou ainda originalidade do mesmo documento. A troca de papéis entre os sujeitos e a transformação da demanda constitutiva positiva em acertamento negativo, entretanto, confere aos envolvidos tratamentos opostos.

Se a conceituação de causa petendi não se manteve homogênea entre as diversas espécies de ação, o método de identificação da demanda, como se disse no início do tópico,

\footnotetext{
${ }^{16}$ CANOva, La domanda, cit. p. 19.

${ }^{17}$ Chiovenda, Principios, cit., p. 342.

${ }^{18}$ CANOva, La domanda, cit. pp. 19-20.
} 
também não foi constante. CHIOVENDA, em suas Instituições, abandona a autonomia dos dois elementos objetivos e amolda ambos em uma estrutura unitária, na qual a causa de pedir desenvolve uma função instrumental na definição do pedido. Com isso, ganha relevância o bem controverso e deixa-se de lado a visão puramente processual do procedimento identificativo. ${ }^{19}$

Não obstante as inúmeras críticas recebidas - das quais algumas delas puderam, ainda que resumidamente, serem aqui expostas -, sem dúvida alguma CHIOVENDA foi um dos juristas que mais influenciou os doutrinadores de seu tempo e aqueles que vieram na seqüência. A bem da verdade, sua doutrina sobre os tria eadem, até os dias de hoje, pode ser notada como premissa teórica dos mais diversos trabalhos e decisões judiciais.

No que tange à esfera doutrinária italiana, nota-se que mesmo antes de 1942, quando então o atual Codice di Procedura Civile entrou em vigor, as lições do autor em debate ecoavam entre os pensadores, quer para refutá-las quer para defendê-las.

Tratar dos pensadores 'pré-codice' individualmente, porém, seria um trabalho árduo e de utilidade questionável. Fato é que as grandes obras de destaque tomaram como referência as idéias chiovendianas, que serviam de medida para as teses ali sustentadas ${ }^{20}$. Comparar a tese criada com aquele de ChIOvEndA era, praticamente, um 'requisito de validade' dos trabalhos.

Alguns traços, todavia, ligam todas as visões e estruturações teóricas. O primeiro deles se refere à possibilidade de se adotarem idênticos critérios para solucionar problemas relativos a mais de um instituto processual; o segundo é a estruturação de uma noção de causa de pedir; o terceiro é o teste dos estudos feitos por meio da aplicação da teoria à casos práticos, principalmente com relação ao tema do concurso de ações. ${ }^{21}$

No que tange ao ponto um, a doutrina buscou responder ao seguinte questionamento: existe um único problema e uma mesma solução para os vários institutos do processo, tais como modificação da demanda, coisa julgada, conexão, litispendência,

\footnotetext{
${ }^{19}$ Observa o ponto GAMBA, Domande, cit. p. 7.

${ }^{20}$ Apenas a título exemplificativo, HeINITZ, I limiti oggettivi, cit.; MARIO BELLAVITIS, L'identificazione delle azioni, Padova, 1924, expressamente pp. 16 e ss.

${ }^{21}$ A constatação é de CANOvA, La domanda, cit. p. 21.
} 
que passam inexoravelmente pela identificação da ação, ou os problemas e soluções são particulares e individuais em cada caso $?^{22}$

Grande parte da doutrina se filiou, com maior ou menor grau, aos ensinamentos de Chiovenda, adotando a metodologia identificativa como ponto de partida para o enfrentamento dos variados nós teóricos dos institutos processuais. ${ }^{23}$

Entretanto, algumas importantes vozes começaram a pôr em xeque essa premissa discordando da linha majoritária. É o caso de MARCO TULLIO ZANZUCCHI, que defende que o pedido e a causa petendi possuem noções variáveis de acordo com o escopo de cada instituto enfrentado ${ }^{24}$. Nota-se, como é importante destacar, que o citado autor não discorda propriamente da metodologia de identificação, mas sim de que os elementos não devem ser interpretados uniformemente em suas variadas aplicabilidades. Individualizar a demanda, pois, era necessário, apenas sendo diferente a forma como isso seria feto em relação a cada instituto.

O segundo ponto que une as teorias é aquele relativo à formação de uma noção de causa de pedir. Tal elemento identificativo é o foco dos estudos desenvolvidos naquele período e alvo de inúmeras discordâncias. Se CHIOVENDA estruturou toda sua tese sobre a causa de pedir em referência aos tipos de ação, EMILIO BETTI, por seu turno, o fez embasando-se nas "razões deduzidas" pelo autor. Tal pensador atribui importância ao direito material afirmado ${ }^{25}$, defendendo que a exposição dessa razão deve abarcar tudo aquilo que for necessário para individualizar a relação jurídica.

Assim, revolvendo observações antigas ${ }^{26}$, afirmou que há relações que podem ser identificadas pela sua própria estrutura, sem que, para isso, seja necessário recorrer aos fatos dos quais se originou. Aponta como representantes dessa categoria os direitos reais que prescindem do título aquisitivo da propriedade-, os direitos de família e ainda aqueles relativos ao status das pessoas. Por seu turno, os direitos obrigacionais, os direitos

\footnotetext{
${ }^{22}$ Aponta para o fato CANOVA, ibidem, p. 22.

23 Segundo CHIOvENDA: "sempre abbiamo davanti un solo problema fondamentale, il problema della identificazione delle azioni (o identità o individiazione che dir si voglia)", Identificazioni delle azioni, cit. p. 159. Assumindo esse ponto de vista expressamente, BELLAVITIS, L'identificazione delle azioni, cit., pp. $16 \mathrm{e}$ 17; HeINITIZ, I limiti, cit., pp. 129-130;

${ }^{24}$ Nuove domande, nuove eccezioni e nuove prove in appello, Milão, 1916, em específico pp. 330 e ss.

${ }^{25}$ Ragione e azione, in Riv. dir. proc. civ., 1932, I, pp. 203 e ss. Com referência às divergências entre os dois doutrinadores, CANOVA, La domanda, cit. p. 22-23; CRUZ E TUCCI, A causa petendi, cit., p. 111-112.

${ }^{26}$ FAZZALARI, Note in tema di diritto e processo, Milão, 1957, p. 117.
} 
potestativos, bem como os direitos de sucessão hereditária dependeriam, por sua própria natureza, dos fatos constitutivos para poderem se diferenciar uns dos outros. ${ }^{27}$

Não obstante haja divergências entre o que seria a causa de pedir, BETTI mantém a metodologia identificativa da demanda para tratar os demais temas processuais. Individualizar a 'razão feita valer', portanto, é um passo fundamental, segundo sua visão, para solucionar problemas relativos à, por exemplo, modificação da demanda.

HEINITZ, após análise da doutrina existente à época, filia-se à visão unitária da identificação da demanda, definindo que a causa de pedir são todos os elementos de fato e de direito que servem para individuar o pedido ${ }^{28}$. Com uma opinião de que causa petendi $\mathrm{e}$ petitum possuem uma relação instrumental identificativa entre si, traça um conceito, segundo seus seguidores, mais amplos do que de seu antecessor. CHIOVENDA teria se expressado no sentido de que os fatos se limitariam às afirmações do autor no âmbito da relação jurídica e que seriam aptas a individualizar o direito particular argüido; HEINITZ, por seu turno, afirmava que os fatos se incluem na causa de pedir na medida em que individualiza a razão posta em juízo ${ }^{29}$. Nesse sentido, a vantagem seria que o conceito do segundo, pela sua maior amplitude, não cairia nas contradições apontadas pelas críticas feitas ao primeiro.

Importante destacar que a obra de HEINITZ, por influxos da doutrina alemã, busca, com o fim de defender o conceito de causa petendi formulado, demonstrar a procedência da teoria da individuação (estrito senso) sobre àquela denominada substanciação. Essa contenda entre uma e outra maneira de interpretar a causa de pedir será esmiuçada um pouco mais adiante. Para o momento, ocorre dizer que tal embate, até os dias atuais, causa polêmica e divide opiniões, principalmente quanto ao instituto da modificação da demanda. ${ }^{30}$

Destaca-se, porém, que o próprio autor assevera, em momento interessante de sua obra, que o fato natural não constitui um critério exauriente para definição da causa de pedir e, como conseqüência, para identificar a ação. Para ele, fundamental é o exame da fattispecie normativa. Atenua posteriormente essa visão ao alegar que, em se tratando de

\footnotetext{
${ }^{27}$ TuCCI, A causa petendi, cit. pp. 111-112.

${ }^{28}$ I limiti oggettivi, cit., p. 165 e ss.

${ }^{29}$ Botelho DE MESQUTA, A causa petendi nas ações reivindicatórias, in Ajuris, 1980, pp. 171 e ss.

${ }^{30}$ CANOva, La domanda, cit. p. 27.
} 
concurso de ações, havendo uma diversidade de fattispecie aplicáveis, resta impossível a compreensão da matéria se observada apenas uma estrutura formal da lógica jurídica. ${ }^{31}$

Há, ainda, contemporânea ao período tratado, a metodologia proposta por CARnElutTI. Segundo o autor, a demanda deveria ser identificada por meio da lide, conceito esse que permeou todo o seu trabalho. A crítica feita a esse posicionamento é o de que a lide possui uma natureza tipicamente sociológica, apresentando, pois, um conteúdo extremamente amplo e indeterminado ${ }^{32}$. Entretanto, suas exposições tiveram o mérito de introduzir uma nova perspectiva de análise da identificação da demanda, abandonando-se a visão trivial dos tria eadem e acrescentando, ainda que com certa resistência, novos conceitos para o debate. $^{33}$

Mesmo com a entrada em vigor do Codice di Procedura Civile, os problemas até então debatidos e seus reflexos na doutrina não cessaram. Os estudiosos continuaram a interpretar os institutos jurídicos processuais - e aqui vai incluído o da modificação da demanda - como um problema posterior ao da identificação da ação. Como se nota, a tendência permanece em encarar os três elementos - causa de pedir, pedido e partes como os instrumentos indispensáveis para o enfrentamento dos problemas ulteriores e específicos dos demais temas. Algumas poucas vozes destoam da grande maioria que seguia CHIOVENDA, mas eram isoladas e não conseguiram infirmar as bases da continuidade metodológica apresentada por ele. ${ }^{34}$

Não obstante a adoção do método identificativo, a doutrina que se sucedeu, e que se dedicou a definir os tais elementos, colocou em questão alguns pontos antes pacíficos. $\mathrm{O}$ conceito de pedido, até então bifurcado, é posto em dúvida ao se questionar: o pedido mediato consiste no direito para o qual se pede a tutela ou a coisa material desse objeto? ${ }^{35}$ Ainda que questionado esse conceito bidirecional, foi no campo da causa de pedir que o foco dos debates permaneceu intenso.

\footnotetext{
${ }^{31}$ HeINITZ, I limiti oggettivi, p. 117.

${ }^{32}$ CANOva, La domanda, cit. p. 29-30.

33 Os reflexos terminológicos podem ser sentido com clareza em FERRARA, Mutamento di domanda giudiziale e conversione di negozio processuale, in For. It., LXVI, 1941, pp. 624 e ss.

${ }^{34}$ Como exemplo, cita-se SAlvatore SATTA, Spunti per una teoria della domanda, in Soliloqui e Colloqui di un Giurista, Padova, 1968, pp. 327 e ss.

${ }^{35}$ Canova, La domanda, cit., p. 34.
} 
A doutrina, muito interessada em definir os limites teóricos do elemento identificativo, se separa entre aqueles que priorizam os fatos jurídicos afirmados e aqueles que defendem que prevalece a situação jurídica exposta. Mais uma vez aparece, com tons mais fortes, a divisão entre a individuação e a substanciação da demanda ${ }^{36}$. Sem fazer, muitas vezes, filiações expressas a uma ou outra corrente, os doutrinadores parecem se preocupar com a diferenciação chiovendiana das ações reais e as ações obrigacionais. É facilmente perceptível nas obras pós 1942, inclusive nas mais atuais, o esforço existente em demonstrar o que seria a causa petendi considerando as especificações de uma e outra ação ${ }^{37}$. Surgem, pois, os conceitos de ação heterodeterminada e ação autodeterminada.

Pelo impacto que o embate doutrinário entre individualização (estrito senso)/substanciação tiveram e ainda tem nos trabalhos e estudos atuais, bem como a atenção dos doutrinadores na dualidade heterodeterminação/autodeterminação, acredita-se, por bem, que seria interessante tratar criticamente esses assuntos de forma apartada, o que daria espaço para aprofundamentos.

Para o momento, entretanto, cabe ressaltar um ponto a título de observação parcial conclusiva sobre a visão italiana: não obstante tenha havido inúmeras linhas de pensamento, cada qual com a peculiaridade dada pelo seu autor, o passo identificativo da demanda parece ser um padrão. Todos os autores buscaram identificar a ação, ora com elementos de cunho mais formal, ora dando atenção aos aspectos substanciais do objeto do processo. Para tanto, faziam-se referências aos fatos e ao conteúdo jurídico desses fatos, ambos elementos que se supunham estar já no ato introdutório do autor claros e definidos. Dessa maneira, a demanda tinha sua identificação no momento da sua propositura.

Fundada nessa metodologia identificativa, naquilo que toca especificamente ao instituto da modificação da demanda, outra celeuma teórica se deu no âmbito doutrinário italiano. Foi a tentativa de diferenciar a chamada mutatio libelli daquela denominada emendatio libelli. ${ }^{38}$

\footnotetext{
${ }^{36}$ Apenas como referência bibliográfica, GIANNOZZI, La modificazione della domanda nel processo civile, Milão, 1958, pp. 35 e ss., ID., Sul mutamento di 'causa petendi', in Gir. It., parte I, Sez. II, 1964, pp. 719 e Ss..

37 Aponta para o fato, MonTESANO, L'invocazione per la prima volta in appello dell'usucapione a fondamento di un'azione di rivendica. Osservassioni in tema di 'ius novorum' $e$ di 'causa petendi', in appello, in Gir. Compl. Cass. Civ., 1948, I, p. 115 e ss,

${ }^{38}$ Apenas a título exemplificativo, para a incidência dessa dualidade e seus limites no âmbito jurisprudencial italiano, com comentários a decisões, ver: AULETTA, Ancora sul mutamento della domanda di esecuzione in
} 
Profundamente ligadas à identificação da demanda e seus elementos, a dita mutatio libelli se dava quando houvesse, por inclusão de novos fatos ou pedidos, uma completa alteração da ação inicialmente proposta, que, segundo os doutrinadores, era vedada pelo ordenamento positivo $^{39}$. A emendatio, a contrario senso, por não configurar uma demanda nova, poderia ser aceita em juízo. ${ }^{40}$

Desse modo, o grande problema passa a ser definir os limites da emendatio. Em outros termos, questiona-se a doutrina até que ponto uma alteração do conjunto fático ou do pedido deixa de ser uma mera emenda e se configura uma mudança por completo da demanda.

Em teoria, quanto ao petitum, afirma-se que qualquer modificação, seja ele referente à faceta mediata ou à imediata do instituto, geraria uma completa mudança dos limites originais da demanda ${ }^{41}$. Logo, alterar o pedido configuraria sempre uma mutatio e seria, pois, proibida.

O problema, mais uma vez, recai sobre a causa de pedir. A doutrina formulou, inicialmente, alguns padrões teóricos para diferenciar a mudança da emenda. Diz-se que haveria a mutatio quando houvesse a alteração de fatos constitutivos da demanda, fatos estes que comporiam a causa de pedir. Qualquer modificação nesse sentido causaria a mudança do elemento identificativo e, por conseqüência, da ação originária. Fatos secundários e irrelevantes, entretanto, poderiam ser objeto de variação sem que tal atividade implicasse em algo proibido. ${ }^{42}$

CORRADO FERRI, porém, constatando que o esquema tradicional era insuficiente para determinadas situações práticas, buscou ampliar os limites de variação dos fatos valorizando o plano do direito material. Tal autor propõe que os limites de vedação da

domanda di risoluzione, in Giur. It., 1950, I, 2, pp. 661-664; CONSOLO, Mutatio libelli: l'accettazione tácita o presunta e l'eccezione di domanda nuova, ovvero di un costruto giurisprudenziale incoerente, in Rev. dir. proc., 1990, pp. 620 e ss.; D'ANGELO, In tema di 'mutatio libelli' nel giudizio di primo grado, in Foro It., 1972, I, pp. 3470-3471; RotA, Dalla domanda di adempimento alla domanda di risoluzione, in Riv. dir. proc., 1990, pp. 876 e ss; Mosco, Azione per adempimento e azione di risoluzione per inadempimento, in Foro It., I, 1951, pp. 1280-1282; ENZO VULLO, Le sezioni unite si pronunciano in tema di inammissibilità della domanda nuova, rilevabilità d'ufficio del vizio e accettazione del conttraditorio, in Giur. It., 1996, I, 1, pp. 1440-1452.

${ }^{39}$ Apontando para o fenômeno, GAMBA, Domande, cit. pp. 52 e ss.

${ }^{40}$ A definição, entre tantas equivalentes nesse sentido, pode ser vista em ALDO SCHERMI, In tema di mutatio ed emendatio e di notifica delle domande nuove al contumace, in Giust. civ., parte I, 1960, p. 2125.

${ }^{41}$ GIANNOZZI, La modificazione della domanda, cit. p. 53.

${ }^{42}$ Nesse sentido, GIANNOZZI, ibidem, p. 12 e ss.; SCHERMI, In tema di mutatio, cit., pp. 2127 e ss.. 
mutatio deveriam ser vinculados ao que a jurisprudência chamava de "novo tema de pesquisa ou novo tema de decisão". 43

A evolução desse posicionamento estaria, segundo alguns estudiosos, no fato de que a vedação de alteração dos elementos abarcaria tão somente a inclusão no debate processual de novos direitos, deixando de lado o perfil processual das visões anteriores. ${ }^{44}$

Entretanto, ainda que se possa identificar uma preocupação importante com o direito material, a estrutura proposta não resolve os problemas práticos, mas tão somente os desloca da individualização da causa de pedir para a identificação do novo tema de pesquisa, conceito com limites tão abstratos e controversos quanto os demais. ${ }^{45}$

Um pensador, entretanto, pôs luz a algo que será de extrema valia ao desenvolvimento do presente trabalho. Seu nome é LUIGI MonTESANO. Questionando-se a premissa uniforme da metodologia até então usada, seu trabalho gira em torno da seguinte pergunta: estaria já a demanda e seus elementos identificados na fase de postulação ou os seus limites iriam se definindo com a dinâmica processual, isto é, com o evoluir das fases procedimentais? Conclui o autor que a identificação da ação e a exata definição da causa de pedir e do pedido era algo dinâmico ${ }^{46}$, algo muito diferente daquilo que vinha sendo aceito (muitas vezes automaticamente) até o momento. A despeito de ainda ele se vincular aos tria eadem, uma nova maneira de enfrentar a definição - ou momento de identificação - dos elementos objetivo estava posta à análise da comunidade jurídica peninsular.

A demanda não mais passa a ser identificada no ato introdutório, mas ganhava seus tons conforme o desenvolvimento processual. Embora sem consciência, o processualista em questão demonstra que os contornos da demanda e da sentença não são idênticos. Em outros termos, põe luz sobre o fato de que o juiz não é um mero verificador dos fatos, tais quais narrados pelo autor, se eles se subsumem à norma apontada em sua inicial e se, como conseqüência, o pedido formulado é ou não procedente. Tal tema será tratado

\footnotetext{
${ }^{43}$ Struttura del processo e modificazione della domanda, Padova, 1975, pp. 90 e ss.

${ }^{44}$ GAmBA, Domande, cit. p. 61; RotA, Dalla domanda di adempimento, cit. p. 907.

${ }^{45}$ Para uma análise sobre a incerteza da definição no âmbito prático jurisprudencial, GAMBA, Domande, pp. 91 e ss., em particular 110 e ss.

${ }^{46}$ Montesano, Dirito sostanziale e processo civile di cognizione nell'individuazione della domanda, in Riv. Trim. Dir. Proc. Civ., 1993, pp. 63 e ss.; ID., Limiti oggettivi di giudicato su negozi invalidi, in Riv. Dir. Proc., 1991, p. 60 e ss.
} 
pormenorizadamente mais adiante. Cabe ressaltar, todavia, que a estrutura gradual da demanda passa a ser algo importante a ser considerado no tema da modificação. ${ }^{47}$

Feita uma breve e superficial análise dos principais traços das linhas teóricas da Itália, passa-se agora à análise de como os alemães enfrentavam o tema.

\subsection{A teoria da identificação do objeto litigioso do processo (Streitgegenstand)}

A doutrina alemã, da mesma forma que aconteceu com os pensadores italianos, se propôs a enfrentar temas processuais partindo-se de uma prévia identificação. Em outras palavras, não obstante a diferença de perspectiva, os alemães se utilizaram da mesma metodologia identificativa para, só depois, enfrentar os nós teóricos dos demais institutos, tais como o da modificação da demanda, dos limites objetivos da coisa julgada, da litispendência etc.

Dessa forma, buscaram encontrar quais eram os elementos de identificação do objeto do processo (ou Streitgegenstand), e, baseando-se nos dispositivos legais da ZPO, debatiam qual era o conteúdo mínimo que deveria conter o ato introdutório do autor.

FRIEDRICH LENT, professor de Erlagen, ao tentar definir o conteúdo mínimo necessário do ato que dá início ao processo, desenvolve sua teoria sobre o Streitgegenstand vinculando-o às relações jurídicas de direito material.

Segundo seu pensamento, o objeto litigioso não é jamais constituído por um simples fato ou acontecimento, mas sim por um direito ou uma relação jurídica. ${ }^{48}$

Entretanto, como é facilmente observável na prática, tal direito (ou relação) pode ou não existir. Em outros termos, ao final do processo, pode o juiz concluir que aquela relação jurídica trazida com a demanda do autor era inexistente, ou seja, que as asserções formuladas na inicial eram infundadas.

\footnotetext{
${ }^{47}$ Para apontamentos críticos em relação ao pensamento de Mntesano, GAMBA, Domande, cit. pp. 223 e ss.

${ }^{48}$ Em suas próprias palavras: "Dobbiamo chiederci a questo punto da che cosa sia costituito l'oggetto della lite nel processo civile. Esso non è mai costituito (come spiegato supra, § $24 \mathrm{IV}$ ) da un semplice fatto od avvenimento, ma da un diritto o da um rapporto giuridico". Diritto Processuale Civile Tedesco. Il Procedimento di Cognizione, Edoardo Ricci (trad.), Nápoles, 1962, p. 149.
} 
Tal constatação, todavia, não influi no raciocínio de LENT. Para o autor em análise, o objeto do processo fundado em uma relação jurídica com ela não se confunde. Afirma o doutrinador alemão categoricamente que o Streitgegenstand é tão somente a afirmação de um direito ou de uma relação jurídica feita pelo autor, e não sua existência verdadeira e própria. O objeto é, pois, extraído de suas asserções formuladas na inicial. ${ }^{49}$

Nesse sentido, para identificar o objeto do processo, era de fundamental importância que o direito sobre o qual versava a demanda fosse claramente identificado, isto é, estivesse individualizado no ato introdutório de modo que não fosse possível confundi-lo com outro direito qualquer (ou outra relação jurídica possível).

Assim, para o processualista em análise, os fatos possuíam importância no sentido de que serviriam como elementos aptos a definir sobre qual relação jurídica (ou qual direito) o autor estaria fazendo menção naquela determinada demanda. Segundo seu entendimento, a pretensão do demandante tem sempre origem em um fato capaz individualizar a relação jurídica posta em debate.

Contudo, como o próprio autor ressalva, "non è tuttavia detto che, per l'individuazione, si debbano sempre narrare tutti $i$ fatti che sostengono la domanda; tavolta è possibile comprendere quale sia il diritto affermato anche in virtù di un'allegazione incompleta". 50

Diante disso, o que se nota é que, para LENT, o Streitgegenstand é composto tão somente pela relação jurídica afirmada pelo autor, sendo os fatos, embora não irrelevantes, apenas importantes em determinadas situações para identificar a natureza da relação material trazida a juízo. ${ }^{51}$

\footnotetext{
49 KARL HeInz Schwab, em análise do pensamento de FrIEDRICH LENT, constata que: "También él lo considera un cocepto procesal. Para acreditarlo basta su opinión de que el objeto del litigio o, como lo llama últimamente, el nódulo del objeto litigioso, no es el derecho material como tal, sino la afirmación de un derecho o de una relación jurídica". El Objeto Litigioso en el Proceso Civil, Tomas A. Banzhaf (trad.), Buenos Aires, 1968, p. 13. SCHWAB, nesse mesmo ponto do trabalho, ainda tratando da diferenciação de objeto do processo e relação jurídica na obra de LENT, afirma que esse último dizia que o objeto é direcionado ao Estado, não ao particular, como é o direito substancial em si.

${ }^{50}$ LENT. Diritto Processuale Civile Tedesco, cit. p. 150.

${ }^{51}$ Demonstrando que os fatos são importantes para identificação do objeto litigioso, LENT diz: "Si discute se l'oggetto della lite resti precisato com la semplice indicazione di ciò che si chiede - come retiene Schwab seguito ora da Rosenberg ( $\$ 88$ II, 2) - o sia necessario guardare anche al fato allegato. Da una considerazione del fatto, però, non possono prescindere nemmeno i sostentori della prima tesi”. Idem Ibidem. Em outro trecho, afirma: "Se dunque il fatto è necessario per l'individuazione dell'oggetto medesimo, ciò vuol dire che ne è una componente: ed il cambiamento dell'uno comporta il cambiamento dell'altro Diritto Processuale Civile Tedesco, cit., p. 151. Por outro lado, quanto às ações que não são de natureza
} 
Deve-se ponderar, todavia, que a individualização do direito material não se confunde, para LENT, com a qualificação jurídica dada aos fatos. Afirma ele que a primeira tem o objetivo de precisar o concreto direito feito valer na demanda, já a segunda - a qualificação - tem como escopo classificar os acontecimentos como representante de um dos tipos previstos em abstrato pela lei. A primeira atividade não necessariamente requereria o cumprimento da segunda para se efetuar a contento. ${ }^{52}$

Desse modo, para ilustrar o ponto, LENT afirma que um contrato pode ser perfeitamente individualizado pela indicação das partes que o compõe, a data de sua celebração, bem como com o apontamento de seu conteúdo, sem que seja necessário qualificá-lo como sendo de locação ou de arrendamento. ${ }^{53}$

Alerta ainda o professor de Erlangen que a atividade de identificar a relação jurídica cabe ao autor, por meio de sua demanda, ao passo que a qualificação jurídica da relação apontada é tarefa do magistrado. ${ }^{54}$

Estando, pois, o Streitgegenstand ligado tão somente à relação jurídica afirmada pelo autor, e não sendo obrigatório o apontamento da qualificação jurídica na inicial, conclui-se, pela lógica, que a alteração do fundamento legal indicado pelo requerente não altera o objeto litigioso, vigorando com largueza, pois, o princípio do iura novit curia nessa vertente do pensamento. As enunciações fáticas, por seu turno, somente poderiam ser alteradas se não descaracterizassem os direitos inicialmente afirmados.

Entretanto, tal construção teórica não passou ilesa pelas críticas.

SCHWAB, em seu trabalho sobre o Streitgegenstand, questiona duramente as assertivas do autor em tela. Inicia a análise sobre essa tese afirmando que as definições de objeto litigioso utilizadas por ela não são sempre uniformes.

Nesse ponto, diz que LENT, em seu tratado, usa algumas expressões como sendo sinônimas. Ora chama o objeto litigioso de direito ou de relação jurídica (afirmados pelo autor), ora o trata como sendo uma conseqüência jurídica. Ainda, em momento posterior,

obrigacionais, "Lent entende suficiente a afirmação de direito material deduzido para delimitar o objeto do processo nas ações atinentes aos direitos reais, sendo irrelevante o título de aquisição", TUCCI, A Causa Petendi, cit., p. 98.

${ }^{52}$ LENT. Diritto Processuale Civile Tedesco, cit., p. 151.

${ }^{53}$ Idem, Ibidem.

54 "L'atore non ha dunque alcun bisogno di presentare la sua affermazione di diritto già qualificata dal punto di vista dei concetti giuridici, né di richiamare alcun paragrafo di legge". Idem Ibidem. 
utiliza a derivação conseqüência jurídica concreta para designar o próprio Streitgegenstand. ${ }^{55}$

Ocorre, todavia, que todos esses termos não versam sobre a mesma coisa, isto é, sobre o mesmo instituto jurídico. ScHWAB, em crítica incisiva, alerta que "no debe pensarse que todo derecho material cuenta con uma consequencia jurídica que le es própria y exclusiva. Por el contrario, varios derechos materiales pueden tener una misma consequencia jurídica". 56

Para confirmar a opinião esposada no trecho acima transcrito, o crítico alemão cita exemplo relativo a um determinado sujeito que propõe uma demanda para obter a restituição de um cavalo roubado de seu estábulo. A condenação na entrega do animal seria a conseqüência jurídica, que teria fundamento em várias pretensões materiais, como a possessória ( $\$ 861$ do BGB) e/ou a petitória ( $\$$ 985, também do código civil alemão).

Logo, a oscilação quanto ao conteúdo dos conceitos seria um entrave à sustentação da tese de LENT.

Outra crítica tecida, derivada da primeira, é que consequiência jurídica estaria ligada à petição, e a relação jurídica material (ou direito) à afirmação do demandante. SCHWAB firma posição alegando que o Streitgegenstand não pode ser tanto um como o outro. ${ }^{57}$

Ao que se dessume das considerações contrárias (que não se restringem a essas expostas no presente trabalho) e dos argumentos que sustentam a tese em lume, tanto os críticos quanto o autor criticado parecem afastar-se demasiadamente das circunstâncias concretas. Todos eles formulam conceitos teóricos complexos e abstratos ${ }^{58}$ para, somente depois, tentar aplicá-los a inúmeras circunstâncias concretas variáveis (método dedutivo), mas falhando em parte das tentativas.

Por fim, ao conceituar o objeto litigioso baseando-se unicamente na alegação de um direito material (ou de uma relação jurídica) feita pelo autor, LENT condiciona os limites

\footnotetext{
${ }^{55}$ Em suas palavras: "Pero si bien el derecho material es fundamentalmente el factor central de la teoría di Lent, sus definiciones no son siempre uniformes. Al practicársele un examen más detenido surgen una serie de dudas" El Objeto Litigioso, cit. p. 15.

${ }^{56}$ Ibidem, p. 16.

57 "El objeto litigioso no puede ser tanto uno como lo otro. La petición contiene siempre, pero no es, la afirmación de un derecho. El objeto debe ser , por consiguiente, o la petición, o la afirmación de un derecho". El Objeto Litigioso, cit., p. 17.

${ }^{58}$ Luiz Guilherme MarinOni. Teoria Geral do Processo, v. I. São Paulo, 2011, p. 404.
} 
desse instituto jurídico à variação formal da peça introdutória da demanda. Em suma, a mesma crise de direito material poderia, dependendo da maneira como o autor formulasse suas alegações, ensejar ações com objetos litigiosos distintos. Essa volatilidade conceitual, todavia, é inaceitável do ponto de vista científico para seus críticos. ${ }^{59}$

Em relação à variabilidade das narrações fáticas e jurídicas, bem como da formulação do pedido, maiores considerações serão traçadas adiante. Contudo, importante notar que, para a doutrina tradicional, esse fator é algo preponderante para afastar a validade da tese de LENT, mas que, ao final e a cabo, ignorando as perspectivas epistemológicas da formulação do ato inicial, acabam por cair na própria falha apontada.

Outro autor alemão que tentou buscar um conceito de Streitgegenstand foi LEO Rosenberg, professor da Universidade de Munique. Contudo, ao tratar da obra deste doutrinador, tal como acontece com CHIOVENDA, dificilmente se poderá afirmar peremptoriamente que este ou aquele é o conceito por ele estabelecido.

Isso ocorre porque RoSENBERG, ao longo de sua produção literária jurídica, oscilou quanto à definição de objeto litigioso que entendia correta. Durante as três primeiras edições de seu Tratado de Direito Processual Civil, o autor definia a idéia de Streitgegenstand como sendo uma petição destinada a obter uma declaração, susceptível de formação de coisa julgada, de uma conseqüência jurídica, que é caracterizada pela solicitação apresentada e pelo estado de coisas exposto para fundamentá-la.

Todavia, já na quarta edição - de resto, mantida na quinta -, a definição adotada para o objeto litigioso se modifica um pouco, começando os fatos a perderem força como elemento necessário à sua composição. ROSENBERG mantém praticamente intacta a estrutura antes proposta, incluindo a expressão 'en cuanto sea necesario' antes de 'estado de cosas' 60

\footnotetext{
${ }^{59}$ Para ilustrar a inaceitabilidade desse conceito 'volátil', invoca-se exemplo trazido por SCHWAB, no qual, ao analisar o instituto da cumulação de demandas, cita um determinado sujeito que pleiteia em juízo a condenação de outro indivíduo na quantia de 1.000 marcos, fundando sua ação em compra e venda de mercadorias e na assinatura de uma confissão de dívida, por parte do comprador, relativa ao negócio entabulado: "Según la nueva teoría de LENT, en este caso hay solamente un objeto litigioso se el actor peticiona una sola condena y le es indiferente si triunfa en virtud de la pretensión material basada en el contrato de compraventa o de la basada en el reconocimiento. Pero si reclama la condena del demandado a base de ambos criterios, habría una cumulación de acciones”. El Objeto Litigioso, cit., p. 103.

${ }^{60}$ Objeto litigioso, nessa nova versão, seria "la petición dirigida a obtener la declaración, susceptible de autoridad de cosa juzgada, de una consecuencia juridica, y que es caracterizada por la solicitud presentada y, en cuanto sea necesario, por el estado de cosas expuesto para fundamentarla". Tratado de Derecho Procesal Civil, v. II, Angela Romera Vera (trad.), Buenos Aires, 1955.
} 
Já na sexta edição do mesmo Tratado, RosENBERG exclui definitivamente os fatos do conceito de Streitgegenstand ${ }^{61}$. Contudo, não obstante as oscilações em suas opiniões acima narradas, o autor traça considerações interessantes que merecem ser alvo de atenção.

Uma delas consiste no fato de o autor apontar que a Zivilprozessordnung traz três acepções para a expressão 'objeto litigioso'. A primeira delas, que pode ser observada nos $\S \S 60$ e 148, é equivalente à relação jurídica sobre a qual deve o juiz sentenciar. Assim, nas ações condenatórias, é a relação material em razão da qual o autor exige a prestação do demandado. Por outro lado, nas ações declaratórias é a relação que se deve declarar existente ou inexistente, válida ou inválida. Por último, nas demandas constitutivas, é o direito que se faz valer para a formação de outro direito. ${ }^{62}$

Outro significado de objeto litigioso adotado pela ZPO e indicado pelo jurista é equivalente à pretensão, isto é, à afirmação de um direito à prestação (em ações condenatórias), a afirmação de existência ou inexistência de uma relação jurídica (demandas declaratórias), ou ainda a afirmação de que ao autor corresponde um direito à constituição de outro direito (ações constitutivas). ${ }^{63}$

O terceiro significado apontado por ROSENBERG que preenche a expressão 'objeto litigioso' é o equivalente ao objeto da pretensão processual, ou seja, aquilo que se visa a obter com a demanda: o objeto exigido ( $\$ 268$, inciso 3 , ZPO). No caso das ações condenatórias, é aquilo que se deve dar em pagamento (dinheiro, por exemplo), enquanto nas demandas declaratórias é a relação a declarar e nas constitutivas a relação a modificar. $^{64}$

Destaca RosEnbERG que os sentidos dos termos pretensão e objeto da pretensão não equivalem àqueles trazidos pelo Código Civil alemão, o BGB. Buscando diferenciálos, afirma, por exemplo, que em direito civil se considera como objeto do direito de domínio a própria coisa, ao passo que toma como objeto das pretensões o próprio devedor e seu patrimônio. Aos direitos constitutivos materiais, portanto, faltariam os objetos. Aduz, ademais, ainda servindo-se de exemplos, que a mesma pretensão é exercida por um

\footnotetext{
${ }^{61}$ SCHWAB, El Objeto Litigioso, cit., p. 39.

${ }^{62}$ Rosenberg, Tratado de Derecho Procesal, cit., pp. 27 -28.

${ }^{63}$ ROSENBERG, op.ult.loc.cit.

${ }^{64}$ Ibidem, p. 28.
} 
cedente e um cessionário se tomado o caso pela perspectiva do direito civil, sendo, entretanto, duas pretensões distintas se avaliado pela ótica processual. ${ }^{65}$

Ante a essas observações, certo de que a pretensão da ZPO não equivale àquela trazida pelo BGB, resta ao autor determinar um conceito para pretensão processual, fundamental para aquilo que entende como objeto litigioso. Para tal tarefa, LEO ROSENBERG traça alguns apontamentos quanto aos encargos do autor e do juiz no âmbito do processo.

Quanto ao primeiro, destaca que não lhe é permitido somente a alegação de fatos, sem definir quais as conseqüências jurídicas oriunda desses acontecimentos. Em outros termos, RosenberG diz que, segundo o $§ 253$, II, inciso 2, da ZPO, não é dado ao autor expor um situação fática e esperar que o juiz, de ofício, extraia daí quaisquer conseqüências jurídicas que lhe pareçam cabíveis ${ }^{66}$. Ao contrário disso, deve o autor "pretender una consecuencia jurídica determinada (derecho o relación jurídica) como existente o inexistente; y con ello presentar una afirmación de derecho o una afirmación de consecuencia jurídica sobre la que solicita, mediante su petición, uma resolución capaz de autoridad de cosa juzgada". ${ }^{67}$

Desse modo, o relato histórico dos acontecimentos, quando necessário ${ }^{68}$, serviria como fundamento da pretensão deduzida. As conseqüências jurídicas buscadas adviriam, pois, de fatos, que lhes dariam suporte.

Não obstante esse valor dado à narrativa dos acontecimentos, LEO ROSENBERG acredita, assim como LENT, que não é necessário que o autor faça a subsunção do fato à norma abstrata prevista em lei, ou seja, não precisa a parte aplicar em sua inicial designações técnicas. Tal tarefa é atribuída pela ZPO ao juiz, que não está adstrito aos fundamentos legais apresentados pelo demandante. Vigoraria, pois, com total liberdade para esse jurista, o princípio da iura novit cúria.

${ }^{65}$ Ibidem, p. 29.

${ }^{66}$ RICARDO DE BARRos LEONEL, observando o instituto da litispendência nesta teoria, destaca a relação entre fatos e pedidos: "Rosenberg salienta sua existência na hipótese em que dois processos tenham o mesmo objeto litigioso, isto é, quando se postula determinado pedido com base em um mesmo acontecimento histórico. A diversidade da narrativa dos fatos que constituem o acontecimento importaria, desse modo, em exclusão de identidade de pretensões do mesmo modo que a diversidade de pedidos", Causa de Pedir e Pedido - O Direito Superveniente, São Paulo, 2006, p. 45.

${ }^{67}$ Rosenberg. Tratado de Derecho Procesal Civil, cit., p. 30.

${ }^{68}$ Expressão inexistente, como dito anteriormente, nas três primeiras edições do seu Tratado e suprimida a partir da sexta. 
De tais linhas cardeais desse pensamento, conclui-se que para ROSENBERG "el objeto litigioso no consiste en hechos, sino en una afirmación de derecho derivada de ellos y reclamada". ${ }^{69}$

Nota-se do exposto que o conceito do professor de Munique, embora tenha se alterado em momento posterior, traz elementos interessantes de aproximação entre fatos e conseqüências jurídicas pretendidas (pedidos), buscando priorizar elementos materiais do direito.

Entretanto, a técnica identificativa, como se viu, recai em atos narrativos do autor executados na propositura da demanda.

NIKISCH, mais um autor alemão que buscou conceituar o Streitgegenstand, tal qual ROSENBERG, variou as linhas de definição de sua teoria ao longo dos anos.

Inicialmente, afirmou que o objeto litigioso do processo era a afirmação de um direito feita pelo autor sobre a qual requer uma resolução que seja susceptível de formação de coisa julgada. ${ }^{70}$

Entretanto, tal como observou ScHWAB, o autor em questão não define o objeto litigioso como petição nos moldes de ROSENBERG, mas o faz como afirmação de um direito. Há, como é perceptível, uma alteração no pólo definidor do conceito.

Segundo a teoria de NIKISCH, "o objeto litigioso no podría ser una petición, ya por el solo hecho de que entonces seria idéntico a la acción como acto. Esa identidad no respondería a la terminologia de la ZPO, pues un giro que se encuentra en muchas disposiciones dice que una pretensión es planteada o hecha valer mediante una acción, lo que demuestra que accción y pretensión no podrían ser conceptos sinónimos".71

Em continuação, diz que a afirmação de um direito é determinada, antes de tudo, pela solicitação apresentada. É com o pedido que o autor diz sobre o quê deve o juiz se manifestar e sobre qual objeto deve ele decidir. Ao requerer uma determinada tutela com um específico conteúdo, pleiteia-se, conseqüentemente, a correspondente afirmação de um

\footnotetext{
${ }^{69}$ RosenBERG, ibidem, p. 35.

70 Aponta para o conceito SCHWAB, Objeto Litigioso, cit., p. 59.

${ }^{71}$ SCHWAB, op.ult.loc.cit.
} 
direito. Esta afirmação, por seu turno, ainda segundo seu pensamento, deverá vir destacada de tal forma que consiga distinguir a afirmação do direito de todas as outras possíveis. ${ }^{72}$

Nota-se, por essa perspectiva, que os fatos seriam responsáveis, em alguns casos, para a individualização do que configura a pretensão. Em outras situações, apenas as pretensões em si seriam suficientes para a individualização da afirmação de um direito.

Como exemplo, cita o autor uma demanda que visa ao recebimento de 1.000 marcos alemães. Caso 500 marcos sejam oriundos de um contrato de compra e venda e os outros 500 advindos de um contrato de mútuo, há aqui duas pretensões distintas e, portanto, uma cumulação de demandas.

Contudo, caso o autor apresente uma série de estados de fato, mas formule uma só pretensão, ter-se-ia, segundo ele, uma cumulação alternativa de demandas. Logo, havendo uma pluralidade de pretensões, tem-se, outrossim, uma pluralidade de demandas. Havendo uma só pretensão baseada em vários estados de fato, ter-se-ia uma cumulação alternativa. ${ }^{73}$

Desse modo, pode-se concluir que a alteração da demanda poderia ser constatada quando houvesse alteração da solicitação feita pelo autor ou quando se modificassem os estados de fato, desde que a alteração destes implicasse a alteração da 'solicitud' originária. $^{74}$

Outra teoria importante é aquela desenvolvida em conjunto por STEIN - JONAS SCHÖNKE. Sua estrutura é a que mais se distancia dos padrões estabelecidos pelas demais idéias até aqui expostas. Tais autores, em comentário ao instituto do objeto litigioso,

\footnotetext{
${ }^{72}$ Em rápida, porém precisa análise sobre o pensamento desse autor, TUCCI assim se manifesta: "Partindo, como visto, da concepção de que o objeto litigioso do processo nada mais é do que a afirmação jurídica (Rechtsbehauptung), mediante a qual o autor requer a prolação de uma decisão idônea a adquirir autoridade de coisa julgada, Nikisch reputa relevante, no processo de conhecimento de natureza condenatória e constitutiva, a exposição do fato constitutivo (Lebensvorgang; em vernáculo: acontecimento da vida, episódio da vida) para ser determinada a aludida afirmação à pretensão ao pagamento ou à modificação jurídica". E, mais adiante, adverte: "Todavia, seguindo a orientação norteadora da aludida tese da individualização, salienta que o mesmo não ocorre em se tratando de demandas de natureza real ou referentes a direitos absolutos, nas quais a respectiva situação subjetiva delineia-se suficientemente individuada pelo conteúdo do direito controvertido", A Causa Petendi, cit., pp. 97-98.

73 Traz o apontamento SCHWAB. Objeto Litigioso, cit., p. 65.

${ }^{74}$ Demonstrando em quais situações os fatos são irrelevantes, LEONEL destaca: "Se o autor afirma um direito ou relação jurídica já individualizada, estará delimitada também sua afirmação. Por isso, nas ações de declaração de um direito ou relação jurídica (exceção aos direitos de garantia), a afirmação jurídica é determinada apenas pelo pedido. A fundamentação não influencia a definição do objeto litigioso. Entretanto, nos direitos reais de garantia, será necessária a fundamentação. Isso em razão da possibilidade de multiplicidade de direitos semelhantes entre as mesmas partes, ou gravando o mesmo bem, por mais de uma obrigação ou divida", Causa de Pedir e Pedido, cit., p. 46.
} 
definem-no como sendo a petição do autor de uma pronúncia mediante sentença da conseqüência jurídica de um determinado fato-tipo material (Tatbestand). ${ }^{75}$

Por Tatbestand, entendem os doutrinadores, ser o estado de coisas sobre o qual o autor fundamenta sua demanda. Nota-se, por esse ângulo, que o conceito de objeto litigioso ora apresentado tem como tônica os fatos alegados.

Diferentemente da concepção de ROSENBERG, STEIN - JONAS - SCHÖNKE afirmam que o estado de coisas sempre será elemento fundamental, independentemente da natureza da demanda, para definir o Streitgegenstand, e não somente "quando necessário" para individualização da solicitação apresentada.

Nesse sentido, para tais juristas, haveria cumulação de demandas "tanto em decorrência da pluralidade de causas ou complexos de fatos, como da multiplicidade de pedidos" $"$. Outrossim, a modificação da demanda poderia ser constatada, segundo a definição proposta, quando houvesse modificação do complexo fático típico (Tatbestand) ou do próprio pedido originariamente formulado, ainda que o novo requerimento repouse sobre os mesmos fatos narrados.

Decorre daí que, em caso de improcedência de uma determinada demanda, basta que o autor re-proponha a ação com fundamentos fáticos distintos para afastar quaisquer óbices da coisa julgada material anterior.

SCHWAB, a despeito de não concordar com a inclusão dos fatos no conceito de objeto litigioso do processo, como se verá adiante, afirma expressamente que a teoria conjunta de STEIN - JONAS - SCHÖNKE é a única unitária dentre todas as apresentadas, independentemente se aplicada aos institutos da cumulação ou modificação de demandas, à litispendência ou à coisa julgada. Da mesma forma, o conceito mantém-se estável, segundo o crítico, sem modificações adaptativas, se testados em ações de natureza condenatória, constitutiva ou declaratória. ${ }^{77}$

Para o presente trabalho, contudo, o ponto fundamental é que, também eles, não obstante a coerência apontada, mantiveram a metodologia identificativa para

\footnotetext{
${ }^{75}$ SCHWAB. Objeto Litigioso, cit., p. 73.

${ }^{76}$ LeONel, Causa de Pedir e Pedido, cit., p. 47.

${ }^{77}$ ScHWAB. Objeto Litigioso, cit., p. 99.
} 
enfrentamento dos mais variados temas processuais, além de terem instituído como elementos de identificação as asserções contidas na inicial do autor.

SCHWAB, após tecer linhas gerais sobre as principais teorias do objeto litigioso do processo na doutrina alemã, traça limites próprios para uma definição do que seria o Streitgegenstand.

É de se ressaltar que o jurista formula seu conceito buscando evitar cair em sua mais intensa crítica quanto às demais teorias, qual seja, a variação dos limites do instituto quando aplicáveis aos temas mais sensíveis do processo. ${ }^{78}$

SCHWAB intenta, desse modo, construir uma definição que seja unitária e aplicável sem distorções a todos os tipos de demandas, sejam elas condenatórias, constitutivas ou declaratórias. E, após definir o conceito de objeto litigioso que acredita correto, testa-o à luz dos temas da cumulação da demanda, de sua modificação, da litispendência e da coisa julgada. $^{79}$

Para este autor, o Streitgegenstand teria natureza fundamentalmente processual, podendo-se defini-lo como "la petición de la resolución designada en la solicitud" ${ }^{80}$

Seguindo a formulação de BöTTICHER, que desenvolveu um conceito de objeto litigioso a partir do pedido de divórcio (Sheidungsverlagen), e ampliando-a a todas as demandas existentes, aduz o autor que os fatos não estariam incluídos no conceito de objeto litigioso, limitando-o tão somente à solicitação feita pelo demandante (Begehren des Klägers).

Assim, valendo-se de exemplificações, afirma que caso alguém reclamasse a devolução de um determinado piano com fundamento na propriedade do bem e o réu levantasse em sua defesa o fato de estar na posse do instrumento devido a um contrato de locação celebrado com o autor, poderia este, pela visão de SCHWAB, fundamentar o pleito condenatório em novo acontecimento, isto é, na extinção do negócio jurídico, pois não

\footnotetext{
78 "Para todos los demás autores, el objeto litigioso no es um concepto unitario en las distintas cleses de acciones, o es apliclable de manera no uniforme en la acumulación de acciones, la modificación de la demanda, la excepción de la litispendencia y la cosa juzgada”, Idem, Ibidem.

${ }^{79}$ LeONEL. Causa de Pedir e Pedido, cit., p. 49.

${ }^{80}$ SCHWAB, Objeto Litigioso, cit., p. 251.
} 
haveria, segundo este doutrinador, modificação do pedido (Antrag) e, por conseqüência, do objeto litigioso. $^{81}$

Do mesmo modo, cita ainda outra situação concreta em que, segundo sua visão, quase todos os autores entendem haver modificação da demanda, mas que em sua teoria isso não ocorre. É o caso de um demandante que propõe uma ação contra $\mathrm{B}$, titular de uma herança, visando à entrega de um relógio de ouro, fundando sua pretensão na transferência em vida do bem por constituição possessória ( $(930, \mathrm{BGB})$. Se o réu negar o fato constitutivo apontado, nenhum óbice haveria ao autor em modificar o fundamento para alegar ser o único herdeiro do de cujus, antigo titular do relógio. ${ }^{82}$

Nesse sentido, não havendo alteração do pedido de entrega do bem, não há alteração da demanda, já que o estado de fato não comporia, segundo SCHWAB, o Streitgegenstand.

Entretanto, em determinadas circunstâncias, os fatos teriam para o jurista a importância de tão somente identificar e individualizar as solicitações apresentadas, isso no sentido de verificação se há ou não cumulação de demandas, principalmente em ações que versam sobre obrigações em dinheiro. Assim, os acontecimentos fáticos seriam úteis para identificar se, na espécie, há uma única pretensão a um determinado valor ou se, ao invés disso, pleiteia o demandante várias vezes e a quantia postulada totaliza a soma de várias pretensões. ${ }^{83}$

Nota-se, nesse sentido, que embora os fatos tenham função atrelada ao objeto litigioso, não compõem o conceito deste, isto é, não fazem parte do Streitgegenstand.

Todavia, o encerramento do conceito de objeto litigioso apenas no Antrag não se mantém constante ao longo do desenvolvimento da tese de SCHWAB. Ao aplicar a teoria ao tema da coisa julgada, o autor contradiz sua premissa e inclui os fatos como abrangidos pela imutabilização.

LEONEL, ao analisar esse ponto da tese, aponta que, após o julgamento do caso, " $o$ centro de interesse não se encontrará mais no objeto litigioso, mas sim na decisão ou resolução do tribunal a respeito desse objeto. Esta é que passará em julgado, e na medida

${ }^{81}$ SChwAB, Ibidem, p. 148. Sobre este pensamento com o foco na causa de pedir ver TuCCI, A Causa Petendi, cit., p. 101.

${ }^{82}$ SChWAB, Objeto Litigioso, cit., p. 147.

${ }^{83}$ LeONEL. Causa de Pedir e Pedido, cit., p. 49. 
dos limites da res iudicata estará terminantemente encerrada a controvérsia", destacando que "torna-se necessário, a partir de então, identificar a essência da resolução ou decisão judicial, para que se possam compreender os limites da coisa julgada, na definição de Schwab. E no particular, fica clara sua mudança de perspectiva: a decisão encontra-se, sobretudo, no dispositivo da sentença. Mas não é só essa 'fórmula' que recebe a autoridade da res iudicata, mas sim o próprio conteúdo da determinação judicial, que deve ser complementado ou elucidado por meio da motivação". ${ }^{84}$

Assim sendo, a tão desejada uniformidade do conceito acaba por dissipar-se. Em outras palavras, se desfaz a unidade tão almejada por SCHWAB quando sua proposta é aplicada ao instituto da coisa julgada, vez que inclui ali as enunciações de fato.

Mostra-se, desse modo, insatisfatória a teoria acima descrita. Enclausurar o objeto do processo nos limites do petitum, embora bastante peculiar, não é capaz de solucionar os todos os problemas práticos a que se destina.

Outra tentativa de identificação do objeto do processo é feita por WALTER HABSCHEID, que desenvolve uma teoria que possui natureza claramente processual. Para tal autor, a definição do Streitgegenstand por meio do direito material é possível tão somente no plano teórico e abstrato, sendo, contudo, inviável sustentá-lo em concreto sem que se atente contra o sistema legal de direito civil, que prevê uma pluralidade de direitos, todos diversos entre si, com variadas condições de existência, extinção, prescrição etc. ${ }^{85}$

Desse modo, aduz que os doutrinadores devem formular seus conceitos e teorias em observância às normas postas, com obediência crítica às previsões legislativas.

Partindo dessa premissa positivista, alega que há no sistema processual alemão um dispositivo decisivo para que se possa delimitar o conceito de objeto litigioso, qual seja, o $\S 253$, número 2 , que afirma que o ato postulatório deve conter a coisa demandada (Gegenstand) e a causa que motiva a demanda (Grund).

\footnotetext{
${ }^{84}$ LEONEL. Ibidem, p. 51. No mesmo sentido, são as observações de TUCCI: "é bem de ver, outrossim, que a orientação defendida por Schwab foi secundada por inúmeros outros cultores do direito processual, que, em linhas gerais, centram no pedido o conteúdo do objeto litigioso. Mas foi também guerreada por não ter sido mantida a necessária coerência e unidade conceptual, visto que, para determinar o objeto da decisão, atingido pela coisa julgada, Schwab recorre à causa petendi”, A Causa Petendi, cit., p. 102.

85 Walter Habscheid, L'oggetto del Processo nel Diritto Processuale Civile Tedesco, Angela Loaldi (trad.), in Riv. dir. proc., 1980, p. 457.
} 
Por coisa demandada, entende HABSCHEID como sendo aquilo que o autor espera do juiz. Cita como exemplo a condenação do réu ao pagamento de 1.000 marcos, a restituição de um carro ou outro objeto qualquer, a declaração de um direito de propriedade, a anulação ou a dissolução de um matrimônio etc.

Aduz, nesse sentido, que a coisa demandada não é um direito subjetivo individuado por uma qualificação legal ${ }^{86}$, como dantes afirmado por outros doutrinadores, mas sim o fato de que o autor pretende um determinado conteúdo, uma específica quantidade de algo ou mesmo um bem definido.

A qualificação legal é tarefa do juiz, que poderá olhar para a situação posta e livremente enquadrá-la na previsão legislativa que entende cabível, ou, em caso de improcedência, reconhecer a inexistência de norma jurídica que fundamente a demanda.

No que se refere ao outro elemento do objeto litigioso - a causa motivadora (Grund) -, HABSCHEID descarta a teoria material que afirma que está no texto de lei a fundamentação da demanda. Para ele, a motivação deve ser concebida como os fatos que compõem a causa petendi do autor.

Tal definição, porém, não resolve o problema, mas traz consigo indagações ulteriores como: quais seriam os fatos que constituiriam a causa de pedir? Para o autor, a resposta seria "tutti $i$ fatti che costituiscono un rapporto di vita (einen Lebenssachverhalt)". Buscando esclarecer a afirmação, cita como exemplo uma demanda de ressarcimento de dano oriundo de um acidente ferroviário, em que os acontecimentos históricos, como a compra do bilhete, o início da viagem, o acidente, dentre outros, seriam os componentes da causa de pedir, constituída por um único estado de fato. ${ }^{87}$

Destarte, para HABSCHEID a causa é um elemento necessário da demanda, divergindo, pois, do posicionamento de SCHWAB, para quem os fatos serviriam somente para interpretar o pedido do demandante. Segundo a visão do primeiro, a lei processual alemã exige a exposição da causa não só para a individualização da demanda, mas, sobretudo, para que ela possa ser substanciada.

\footnotetext{
${ }^{86}$ HABSCHEID. ibidem, p. 458.

${ }^{87}$ HABSCHEID, ibidem, p. 461.
} 
E, nesse ponto, afirma HABSCHEID que a substanciação, alcançada por meio da exposição de fatos, possibilita ao réu, além de identificar sua pretensão, se defender dos acontecimentos que a sustentam, exercendo assim uma defesa plena.

No que se refere à possibilidade de propositura de nova demanda em caso de esquecimento por parte do autor de narrar um fato importante que sustente sua pretensão, assim se manifesta HABSCHEID: "lo stato di fatto è immutabile, non è lasciato alla disponibilità delle parti. Se dunque l'attore dimentica di far valere un fatto che rientra nell'ambito di una data causa non potrà riproporre la domanda perchè il fato sara consumato dall'autorità del giudicato". ${ }^{88}$

Como se nota, a conceituação ora em análise opta por um método positivista para a solução dos problemas práticos, método no qual a resolução das dificuldades deve ser analisada tomando como parâmetro a lei e os elementos processuais.

Diante de tudo o que foi até aqui exposto referente ao Streitgegenstand, algumas conclusões parciais podem ser tracejadas. Tal como aconteceu com a teoria dos tria eadem e a identificação da demanda, muitos conceitos relativos à individualização do objeto do processo foram elaboradas, cada qual com sua especificidade. $\mathrm{O}$ foco das atenções dos estudiosos, que ora predominava sobre os fatos ora sobre os pedidos, independentemente da linha adotada, sempre foi no ato introdutório formulado pelo autor. O objeto litigioso, conforme se viu, deveria vir delimitado já no primeiro ato do procedimento. Sem levar em conta as especificidades da formulação da petição inicial, todos os autores analisados bloqueavam o seu conteúdo da causa na fase postulatória, dando à demanda um caráter estático.

Analisada a segunda matriz de pensamento, cabe agora enfrentar as grandes polêmicas referentes ao tema da modificação, quais sejam, os embates entre individuação/substanciação, de um lado, e autodeterminação/heterodeterminação, do outro.

\subsection{O embate substanciação $x$ individuação e a modificação da demanda}

${ }^{88}$ Idem, ibidem. 
O presente tópico do trabalho buscará expor, ainda que de maneira superficial e panorâmica, uma da querelas mais citadas em termo de modificação da demanda: a teoria da substanciação em contraposição à teoria da individuação.

$\mathrm{O}$ argumento se faz importante pelo fato de que, ainda nos dias atuais, algumas sentenças encaram o instituto modificativo filiando-se a uma ou outra vertente ${ }^{89}$. A despeito da perda de oxigênio que o tensionamento teve nos últimos anos, analisar os dois posicionamentos teóricos explica-se pela relevância prática que ainda oferecem.

Antes de adentrar propriamente no embate citado, porém, vale ressaltar que ambas as teorias são destinadas a identificar quais seriam, cada uma a sua maneira, os elementos componentes da causa petendi e, como consequiência, para identificar a demanda. Em outros termos, o debate em lume só tem razão de ser se o que se busca fazer é identificar a ação. Teorias que encaram os institutos jurídicos do processo, tais como a modificação, a coisa julgada, a litispendência, sem identificar um conteúdo mínimo original, conforme se verá adiante, nem mesmo entram nessa seara de questionamentos.

Em relação ao debate em si, destaca-se que para a teoria da substanciação o fato constitutivo do direito do autor é fundamental na delimitação dos contornos da demanda. Por outro lado, a individuação dá seu enfoque no direito afirmado ${ }^{90}$. Em termos gerais, para a primeira, a demanda deve ser elaborada pelo seu autor com a descrição obrigatória dos fatos constitutivos, pois são eles os responsáveis por individualizar cada ação, ao passo que para a segunda basta que o demandante especifique qual relação jurídica é que é objeto de sua vinda ao judiciário.

No que se refere ao instituto modificativo, ambas apresentam, em tese, soluções práticas bastante divergentes. Para os seguidores da substanciação, qualquer alteração dos fatos constitutivos geraria uma modificação da causa petendi e, como conseqüência, dos limites originais da ação ${ }^{91}$. Já para os seguidores da individuação, as modificações dos

89 Apenas como exemplo dos reflexos do debate na jurisprudência brasileira, TJBA, Apl. 000068904.2010.8.05.0091, 5 Câmara Cível, Rel. Des. José Edivaldo Rocha Rotondano, j. 15/01/2013; TJPR, Apl. 1251723-2, 13 ${ }^{\mathrm{a}}$ Câmara Cível, Des. Rel. Lenice Bodstein, j. 12.11.2014; TJPR, Apl. 1181344-8, 17 Câmara Cível, Des. Rel. Lauri Caetano da Silva, j. 15/10/2014; TJPR, Apl. 1684831, 5 a Câmara Cível, Des. Rel. Domingos Ramina, j. 07/06/2005; TJRS, Apl. 70056398001, 11 a Câmara Cível, Rel. Des. Bayard Ney de Freitas Barcellos, j. 26/11/2014; TJRS, Apl. 70062106448, $18^{\text {a }}$ Câmara Cível, Rel. Des. Heleno Tregnago Saraiva, j. 20/11/2014.

${ }^{90}$ Nesse sentido, com grande referência bibliográfica, TUCCI, A causa petendi, cit. pp. 109 e ss.

${ }^{91}$ Faz referência ao fato, FAIREN GUILLÉN, La transformación de la demanda en el proceso civil, Santiago de Compostela, 1949, pp. 23 e ss. 
fatos em nada comprometeriam os contornos da demanda se porventura a relação jurídica posta à base da inicial mantivesse seus limites originários.

Outra diferença existente entre as duas vertentes do pensamento seria que, para substanciação, justamente por identificar a causa petendi por meio dos fatos constitutivos alegados, não haveria óbices futuros para a propositura de outra demanda baseada no mesmo direito. Bastaria que o autor fundamentasse sua inicial em novos acontecimentos. A individuação, por outro lado, teria como premissa a consumação dos fatos pela relação jurídica afirmada. Nesse sentido, a primeira favoreceria uma reabertura do debate e, por isso, seria menos eficaz quanto à solução completa da crise, ao passo que a segunda teria uma abrangência maior quanto aos reais limites do conflito. ${ }^{92}$

A despeito das diferenças apontadas, nota-se que ambas as teorias não são excludentes entre si. Muitos doutrinadores, inclusive, chegam a afirmar que as duas compõem as faces da mesma moeda ${ }^{93}$. Não dá pra imaginar, como é facilmente perceptível, como apontar para uma relação jurídica material sem fazer menção a fatos. Tampouco se pode narrar fatos em um cenário processual sem que a eles se dê uma roupagem jurídica. A questão é que, em termos teóricos, a diferenciação se mostra clara e possível. No âmbito prático, entretanto, jamais haverá uma demanda totalmente individuada ou integralmente substanciada, o que torna a polarização algo pouco útil.

Apontando para essa questão fato, juristas acabaram criando a expressão de que a ação deve ser "faticamente substanciada e juridicamente individualizadas"94. É de se relevar que qualquer relação jurídica é individualizada e identificada pelos fatos das quais ela se originou. Um fato sem qualquer relevância jurídica não pode ser objeto de disputa. Como se vê, a doutrina atual, por meio dos argumentos expostos, colocou em um segundo plano a disputa em análise, fazendo empalidecer a divisão estanque que até então se cria existir entre elas.

Feita essa sucinta análise, passa-se agora para a polarização demanda heterodeterminada x demanda autodeterminada.

\footnotetext{
${ }^{92}$ GIANFRANCO RICCI, 'Individuazione' o 'sostanziazione' nella riforma del processo civile, in Riv. trim. dir. proc. civ., 1995, pp. 1238; LEONEL, Causa de pedir, cit. p. 89.

${ }^{93}$ GIANNOZZI, La modificazione, cit., pp. 51 e ss.; TUCCI, A denominada 'situação substancial' como objeto do processo na obra de Fazzalari, in Repro, 1992, n. 68, p. 273.

${ }^{94}$ FAIRÉN GUILLÉN, La transformación, cit. p. 73; fazendo menção a isso, TUCCI, A causa petendi, p. 123.
} 


\subsection{Demandas heterodeterminadas $x$ autodeterminadas e a modificação}

Muito semelhante ao debate entre as teorias da substanciação e da individuação, surge na doutrina internacional, baseada em ensinamentos romanos ${ }^{95}$, a diferenciação entre demandas autodeterminadas e demandas heterodeterminadas.

Como os próprios nomes sugerem, tais classificações são referentes ao método pelo qual a ação é identificada, isto é, se dependente dos fatos constitutivos para se diferenciarem umas das outras ou se individualizam por si sós. Por outra perspectiva, a classificação apontada faz referência àquelas ações que, pelo seu próprio conteúdo do direito, podem subsistir uma única vez entre os mesmos indivíduos (autodeterminadas), e àquelas que precisam da especificação do cenário fenomênico para que possam ser reconhecidas, haja vista a possibilidade de existirem várias vezes entre os mesmos envolvidos (heterodeterminadas).

Como representante das primeiras, estariam as ações envolvendo, por exemplo, os direitos reais e os direitos reais de gozo. Como representantes das segundas, estariam as ações que envolvem direitos obrigacionais em geral.

Segundo os defensores da divisão, as ações autodeterminadas se embasam no direito de propriedade do autor, que, por só existir uma única vez, independeriam da demonstração pelo demandante do título aquisitivo para que fossem individualizadas entre as demais.

Ao propor uma ação de reivindicação de algo que é seu, o autor não teria qualquer necessidade de apontar em sua inicial por meio de qual título adquiriu aquele bem para si. A propriedade bastaria para que juiz e réu conseguissem identificar o objeto da demanda, já que estariam contemplados ali todos os títulos possíveis. ${ }^{96}$

Por outro lado, as ditas ações heterodeterminadas, por versarem sobre relações jurídicas capazes de coexistirem simultaneamente mais de uma vez entre os mesmos indivíduos, não prescindiriam da apresentação do título por parte de quem demanda em

\footnotetext{
${ }^{95}$ Apontam para o fato, LeOnEl, Causa de pedir e pedido, cit. p. 86; TUCCI, A causa petendi, cit. pp. 39 e ss.

96 TuCCI, ibidem, p. 117. Na mesma linha, CANOVA, La domanda, cit. p. 177.
} 
juízo. O título seria o fato constitutivo do direito do autor responsável por identificar que aquela relação obrigacional é aquela mesmo e não outra qualquer que verse sobre o mesmo objeto. Assim, alguém que pleiteie R \$ 1.000,00 (mil reais) em juízo deve apontar a fonte obrigacional, se um contrato $\mathrm{X}, \mathrm{Y}$ ou $\mathrm{Z}$, por exemplo, sob pena restar indefinido o objeto da demanda.

Em estudo sobre o petitum e causa petendi no processo civil, MANDRIOLI observa que as ações heterodeterminadas teriam o seu foco na causa de pedir, ao passo que as autodeterminadas o direito material apresentaria uma perspectiva dada pelo pedido. ${ }^{97}$

É justamente partindo-se da observação referida acima que algumas críticas à bifurcação teórica ora em análise, da forma como feita, devem ser traçadas. Segundo quem escreve o presente trabalho, não obstante alguns pontos fundamentais dos direitos materiais em jogo tenham sido destacados, há um erro de perspectiva por parte da maioria dos estudiosos quando vinculam o título aquisitivo às ditas ações autodeterminadas como se esse fato jurídico constituísse elemento pertencente à crise posta em juízo. Explica-se.

Ao tratar da ação reivindicatória - exemplo, de resto, usado com maior frequiência pelos doutrinadores ${ }^{98}$-, deve-se ter em mente que se trata de uma ação condenatória. Maiores especificidades sobre a relação entre a natureza da crise e a tutela pleiteada serão traçadas no capítulo seguinte. Contudo, cabe adiantar nesse momento que tais demandas visam a solucionar, em específico, crises relativas a inadimplementos, e, no exemplo dado, não é diferente. ${ }^{99}$

O que se debate nas ações reivindicatórias não é uma crise de certeza quanto ao direito de propriedade em si. Exatamente por isso o autor não precisa demonstrar por quais meios é que ele adquiriu o bem. Nesse sentido, é justamente por ele não estar debatendo a existência de um direito real seu que prescinde de trazer aos autos junto com sua inicial o título aquisitivo.

\footnotetext{
${ }^{97}$ Riflessioni in tema di petitum e di causa petendi, in Riv. dir. prc., 1984, p. 476.

${ }^{98}$ Nesse sentido, Botelho DE MesquitA, A 'causa petendi' nas ações reivindicatórias, cit. pp. 173 e ss.; TUCCI, A causa petendi na ação reivindicatória, in Ajuris, 1997, pp. 184 e ss.

${ }^{99}$ Não se está aqui, como pode parecer, defendendo qualquer tipo de idéia vinculada à tipicidade das ações. O desenvolver do trabalho mostrará isso quando tratar mais adiante da formulação dos enunciados de direito no âmbito da petição inicial. Para maiores aprofundamentos quanto ao tema, remete-se o leitor para YARSHELl, Tutela jurisdicional, São Paulo, 2006, passim.
} 
A questão debatida nessas ações é uma suposta violação de um direito subjetivo por parte de terceiros referente a um usar, um fruir e um dispor do bem pelo seu proprietário. São obrigações oponíveis erga omnes que tem como fonte a lei cível, em específico o art. 1.228., do CC, que expressamente dispõe que o proprietário tem a faculdade de usar, gozar e dispor da coisa, e o direito de reavê-la do poder de quem quer que injustamente a possua ou detenha. Desse modo, ao demonstrar sua propriedade, não precisa trazer a fonte da obrigação inadimplida e que fundamenta sua pretensão, pois essa é a própria norma positiva. Tem o encargo, isso sim, de identificar os fatos que violaram o seu direito, isto é, a chamada causa petendi passiva.

Em relação ao tema da modificação da demanda, afirmam os juristas que eventual alteração pelo autor do título aquisitivo não implicaria em mutatio. Pelas razões expostas, tal não se dá por uma eventual heterodeterminação do direito, mas sim porque a fonte obrigacional responsável por identificar a relação jurídica permanece sempre a mesma, ou seja, a lei civil. O título aquisitivo, repita-se, não faz parte da crise de inadimplemento para a qual o autor busca solução por meio de uma demanda.

Outras obrigações dessa espécie, que possuem com fontes a legislação, seguem a mesma lógica. Uma ação fundada em uma relação de trabalho e que busca ressarcimentos por danos sofridos devido à falta de segurança no ambiente laboral - obrigação essa cabível ao empregador e oriunda do art. $7^{\circ}$, XXII, da Constituição da República, e dos arts. 157, I e II, e 166, todos da CLT - não impõe ao autor o ônus da apresentação da cláusula contratual com essa previsão. Aliás, o contrato de trabalho pode até se omitir quanto à segurança ou mesmo negá-la. Para que o autor tenha êxito em seu intento basta tão somente comprovar o vínculo empregatício, da mesma forma que o proprietário deve se limitar a comprovar sua propriedade.

Eventual mudança pelo autor quanto ao dispositivo contratual, por exemplo, não modifica sua demanda, vez que a fonte que individualiza a obrigação, que é a lei, não se altera.

Por outro lado, ações que versem sobre direitos reais, mas que envolvam uma crise de certeza quanto à existência desse direito (situações, por exemplo, das ações de aquisição originária como a usucapião), os fatos constitutivos são fundamentais para a obtenção da procedência. $\mathrm{O}$ autor deverá expor em sua inicial todos os requisitos legais, tais como 
tempo, posse mansa e pacífica, dentre outros, já que requer em juízo a dissipação de uma incerteza quanto ao próprio direito. ${ }^{100}$

Nesse sentido, ainda que sem maiores aprofundamentos sobre o tema, pode-se perceber que a metodologia de identificação dos requisitos mínimos da petição inicial baseada em uma suposta heterodeterminação ou em uma autoindividuação do próprio direito pode, muitas vezes, não ser tão útil e uniforme. Vincular o instituto modificativo à aludida bifurcação, outrossim, parece não ser o método mais adequado para se tratar do tema.

Os ditos requisitos, como se verá no capítulo posterior, dependerão de elementos muito mais concretos e específicos, tais como a posição epistemológica do autor, seus objetivos ilocutórios, estratégias subjetivamente desenvolvidas por seus advogados. A modificação, por seu turno, dependerá de outros elementos que serão propostos mais adiante.

\subsection{Conclusões parciais}

Após a análise das diversas vertentes do pensamento, algumas conclusões parciais podem ser destacadas. A primeira delas é que, conforme restou demonstrado, muitas são as teorias propostas, mas que nenhuma delas apresenta solução pacífica para os temas processuais relacionados à individualização, dentre eles o da modificação da demanda. Todas elas figuraram como objetos de críticas, ora mais intensas, ora mais suaves, deixando em aberto o problema dos limites da permissão de alteração dos fatos, do direito e dos pedidos no curso do processo.

Outro ponto importante a ser ressaltado é que a grande maioria dos estudiosos filiase à idéia de que o problema passa por um só ó teórico inicial: a identificação da demanda/objeto litigioso. É exatamente nesse ponto de partida que as controvérsias aparecem. O método identificativo, quer pela versão alemã do Streitgegenstand quer pela linha italiana dos tria eadem, dependem de uma noção que parece bastante tormentosa, qual seja: definir o que seria a chamada causa de pedir (Sachverhalt) e o pedido (Antrag) e quais seus papeis para definir o que se pede em juízo. Ocorre, todavia, que cada qual

${ }^{100}$ Aponta para o fato TUCCI, A causa petendi, cit. p. 110. 
interpreta os dois elementos de uma maneira diversa, acarretando, como se viu, concepções variadas de identificação.

Não bastasse isso, não se nota, em linhas gerais, considerações sobre o que seria o fato, qual sua natureza ou mesmo como eles são aportados no âmbito processual. De uma simplificação desses elementos, parte-se direto para a função do mesmo na identificação da ação.

Talvez por essa ausência de abordagem, poucas são as vozes que questionam se tais elementos objetivos estão mesmo já definidos no ato introdutório ou se seus limites, diferentemente disso, vão ganhando cor conforme o processo vai se desenvolvendo. Para eles a demanda vem definida já com a primeira manifestação das partes. Causa de pedir e pedido ganham caráter absoluto e rígido. Em outros termos, por motivos que se verão adiante, os doutrinadores, simplesmente usando a expressão 'fatos' e 'direitos' de maneira simplificadíssima, enclausuram os eventos no ato introdutório (ou, no máximo, na fase postulatória), atribuindo ao cenário fenomênico da crise um perfil estático que, como se verá, não condiz com a dinâmica da formação do juízo e do próprio processo.

Os elementos da demanda, de meros meios informadores, passam a óbices rígidos, com contornos bastante controversos.

Ao que tudo indica, o método que prevê a identificação da demanda como passo inicial do enfrentamento dos demais institutos parece oferecer mais problemas do que soluções. Traz consigo mais dúvidas que certezas e, por isso, deve ser abandonado.

Acredita-se que a modificação de enunciados fáticos e de formulação de pedidos no curso do processo, para que se evite a insegurança causada pelas diversas teorias identificativas, deve seguir uma teorização autônoma dos demais institutos, tudo por suas peculiaridades e funções. ${ }^{101}$

\footnotetext{
${ }^{101}$ Recentes trabalhos dedicados aos institutos que normalmente são vinculados ao método da identificação da demanda vêm propondo a solução aqui adotada: abandonar a técnica identificativa. Exemplo disso é a obra de BRUNO VASCONCElos CARRILHO LOPES, Limites Objetivos e Eficácia Preclusiva da Coisa Julgada, São Paulo, 2012, passim, na qual o autor propõe, dentre outras coisas, uma solução técnica para os problemas da coisa julgada, qual seja: a extensão de seus limites objetivos aos fundamentos da decisão. Ao assim proceder, pouco importa quais são os limites do objeto do processo. Restará imutável aquilo que o juiz colocou à base de sua decisão. A tese em comento compactua perfeitamente com o conceito de modificação da demanda que será proposto adiante. Aliás, as premissas de demanda dinâmica que aqui se verá são complementares ao raciocínio de CARRILHO LOPES.
} 
O capítulo seguinte demonstrará, por perspectiva diversa da adotada pela doutrina clássica, que os fatos do processo não são acontecimentos naturalísticos como a simplificação tradicional faz crer. Ao contrário, são apenas enunciados sobre os fatos, todos construídos com fins específicos e, geralmente, com características de parcialidade e incompletude. $\mathrm{O}$ direito, roupagem jurídica dada às narrações sobre os eventos postos à base da demanda, também é estruturado de maneira subjetiva e direcionada ao vencimento a causa.

Quanto ao ponto, inclusive, acredita-se que exatamente por relegar essa subjetividade da construção da peça introdutória, altamente dependente das condições específicas de cada caso, e usando os termos fatos, direitos e pedidos como sendo algo analiticamente definido, que o número de teorias é incontável, mas que o resultado de todas elas é tão pouco satisfatório.

Enfrentar essas nuances e propor um novo método interpretativo do instituto modificativo é tarefa que se desenvolverá nos próximos capítulos que se seguem. 


\section{A FORMAÇÃO DA DEMANDA}

\subsection{Considerações Iniciais - Retomada de Conclusões.}

O capítulo anterior foi destinado à análise de como a doutrina tem tratado o tema da modificação dos fatos e do pedido no curso do processo. Como se pôde verificar, o tema não teve e não tem um tratamento homogêneo por parte dos estudiosos e, como conseqüência, dos operadores do direito.

A modificação da demanda - ou sua vedação-, como se viu, é um instituto que apresenta inúmeras incertezas e contradições, causando aos jurisdicionados insegurança jurídica, tratamento desigual a casos semelhantes, além de indefinições quanto aos limites modificativos e em que casos sua aplicação se faz possível.

Enfim, a falta de uma sistematização mínima do tema - ou, por outro lado, as inúmeras sistematizações existentes, cada uma partindo de um critério próprio e muitas vezes conflitante com os demais - gera mais problemas que soluções. ${ }^{102}$

Um dos motivos para tamanha divergência, segundo ponto de vista aqui adotado, é a própria nebulosidade dos conceitos de causa de pedir e pedido. Se o segundo apresenta menores problemas, como se viu, o primeiro, por sua vez, é fonte de grandes divergências e objeto de uma interminável discussão nos planos doutrinário e jurisprudencial. $\mathrm{O}$ conceito de causa de pedir, ao que se nota, é impreciso e indeterminado.

\footnotetext{
${ }^{102}$ Em relação às reformas do Código de Processo Civil italiano, em específico do art. 183 daquele diploma e a manutenção da diferença entre mutatio e emendatio libelli, método, como se viu, muito usado pela doutrina para tratar do tema da modificação da demanda, assim se disse: "Sfortunatamente per l'interprete, ed anche per le sorti della riforma, si tratta di un problema che non ha mai conosciuto risposte chiare e soddisfacienti, per la mutevolezza - forse inevitabile - dei criteri di volta in volta impiegati per risolverlo. Per un verso, la giurisprudenza tende a formulare la distinzione tra emendatio e mutatio in funzione dell'alterazione del complesso dei fatti allegati a base della domanda, ma questo criterio si espone a dubbi rilevanti e a soluzioni non facilmente ricunducibili ad unità. Dal canto suo, la dottrina tende tavolta a ritenere rilevante la fattispecie legale invocata, ma altre volte fa capo piuttosto alla situazione sostanziale allegata, ovvero ai fatti giuridici allegati a fondamento della domanda. Soluzioni diverse vengono inoltre prospettate a seconda che si tratti dei diritti c.d. autoindividuati e eteroindividuati. Si giunge così alla formulazione del criterio per cui si ha mera emendatio quando, pur essendo allegati nuovi fatti principali, non cambia la domanda inizialmente proposta, ma non è detto che questo criterio serva ad eliminare tutte le incertezze relative a tale nozione, e alla correlativa distinzione rispetto alla mutatio libelli", TARUFFO, La trattazione della causa, in TARUFFO (a cura di), Le riforme della giustizia civile, Torino, 2000, sec. ed., p 301.
} 
As razões para essas incertezas serão desenvolvidas adiante, não cabendo nesse momento maiores aprofundamentos. Entretanto, vale adiantar aqui algumas conclusões: toda a problemática que circunscreve o instituto da causa petendi, ao menos aos olhos de quem escreve, é fruto e conseqüência de uma abordagem equivocada da narração dos fatos e da qualificação jurídica feita pelo autor em seu ato introdutório. A metodologia de enfrentamento desses elementos é feita de forma extremamente processual e restritiva, ignorando-se alguns dados reais da confecção e criação da peça inicial, bem como a real natureza e limitações das assertivas contidas na primeira manifestação autoral.

O mesmo problema de perspectiva pode ser notado na doutrina alemã do streitgegenstand, que, não obstante as diferenças de abordagem em relação à teoria dos tria eadem, mantém uma análise processual das narrativas dos fatos e dos pedidos formulados pelo autor, existindo também aí um distanciamento da real natureza dessas assertivas.

Fala-se, tanto em uma quanto noutra maneira de identificação, em fatos, sem, contudo, maiores aprofundamentos quanto à natureza desses "fatos processuais". A doutrina clássica não se questiona, ao menos em sua esmagadora maioria, o que seria um fato. Tampouco dão a devida atenção ao que se deve entender por 'fatos' trazidos pelos indivíduos em suas manifestações no bojo do processo. Dos fatos - abstrata e superficialmente considerados -, traçam-se conceitos processuais fechados de causa de pedir, ignorando-se fatores interdisciplinares fundamentais para o enfrentamento da questão.

Acredita-se, portanto, ser um ponto fundamental para a correta interpretação do tema o abandono da visão processual das narrativas dos fatos e dos pedidos, devendo-se enfrentá-los por meio de sua real natureza epistemológica/gnosiológica, proposta de método adotado pelo trabalho.

Ademais, e adiantando aqui mais um ponto que será tratado nesse capítulo, acredita-se que outro equívoco na abordagem do tema da demanda - e de sua modificação, conseqüentemente - é o seu enclausuramento no ato introdutório, conseqüência direta da metodologia de individuação da causa pelas narrações fáticas e/ou pelos pedidos do autor, elementos estes apresentados já no primeiro ato processual como requisitos da inicial (CPC, art. 282, III e IV). ${ }^{103}$

${ }^{103}$ No mesmo sentido, com aprofundamentos, GAMBA, Domande senza risposta, cit., pp. 131 e ss. 
Como se viu alhures, a grande maioria dos estudiosos do tema se utiliza de um método de identificação da causa para, a partir daí, tratar de institutos como $a$ litispendência, a conexão, a coisa julgada e a modificação da demanda. ${ }^{104}$

Quer no pensamento de origem chiovendiana de identificação da ação, partindo-se dos elementos dos tria eadem, quer naquele de origem germânica de individualização do Streitgegenstand, aqui ambos tratados como 'doutrina clássica', o enfrentamento dos institutos processuais acima citados deve passar necessariamente pela individualização da causa, que é feita por meio das narrativas do autor quanto aos acontecimentos de fato, suas qualificações jurídicas, bem como pelos pedidos por ele formulados. Independentemente do peso que cada um dos elementos tenha dentro das diversas teorias, fato é que todos eles estão contidos no ato introdutório ${ }^{105}$. Logo, a demanda é identificada já na primeira manifestação do autor. ${ }^{106}$

A reforçar o trancamento dos limites da demanda no ato introdutório, segundo a doutrina que assim encara o tema, vêm a interpretação restritiva e privatista do princípio dispositivo, a sua vinculação direta com a demanda, além de uma visão distorcida do princípio da correlação entre pedido e decisão ${ }^{107}$. Tais elementos são, pois, com grande freqüência, usados para justificar uma suposta necessidade de individuação da causa no primeiro ato do processo.

\footnotetext{
${ }^{104}$ Aponta expressamente para a questão da necessidade de individuação da demanda DE STEFANO, Per uma teoria, cit., p. 233; CANOVA, La domanda giudiziale, cit. pp. 107-118; SCHWAB, Objeto Litigioso, cit., pp.

${ }^{105}$ Quanto ao peso de um e/ou de outro elemento na identificação da demanda/Streitgegenstand nas diversas teorias, vide capítulo anterior. Cabe ressaltar nessa senda, entretanto, que mesmo para as teorias em que o objeto litigioso do processo é identificado somente pelo pedido, a individualização é o passo inicial obrigatório, levando-se em consideração o ato introdutório do autor. Nesse sentido, vide ScHWAB, Objeto Litigioso, cit., p. 251; LeONEl, Causa de Pedir, cit., p. 49; DE STEFANO, Per uma teoria, cit. p. 231, especificamente nota 13; LENT. Diritto Processuale Civile, cit., pp. 149-150; RoSENBERG. Tratado de Derecho Procesal Civil, pp. 27-28.

106 Flach, Alteração da demanda, 2013, em dissertação de mestrado direito, Faculdade de Direito da Universidade Federel do Rio Grande do Sul, p. 55, é expresso quanto ao ponto, afirmando que "... a determinação do objeto litigioso ocorre com a introdução da demanda". Outros trabalhos acadêmicos recentes também partem da metodologia de identificação da ação/objeto do processo já no ato inicial, tais como Degenszaj, Alteração dos fatos no curso do processo, 2010, em dissertação de mestrado direito, Faculdade de Direito da Universidade de São Paulo, p. 24, e MOREIRA DOS SANTOS, A estabilização objetiva da demanda no direito brasileiro, 2014, em dissertação de mestrado direito, Faculdade de Direito da Universidade de São Paulo, passim. Ademais, na doutrina de destaque, BotelHO DE MESQUITA, a causa petendi nas ações reivindicatórias, cit., p. 140. JUNIOR AlEXANDRE MOREIRA PINTO, A causa petendi e o contraditório, São Paulo, 2007, pp. 17 e ss., em específico quanto à modificação da demanda, p. 22.

${ }^{107}$ Com manifestação expressa em relação aos citados princípios, TAPIA FERNÁNDEZ, El objeto del processo, cit. pp. 10-11 e 26; JUAN MONTERO AROCA, El proceso civil llamado 'social' como instrumento de 'justicia' autoritaria, in ID (coord), Proceso civil e ideologia. Un prefacio, una sentencia, dos cartas y quince ensayos, Valencia, 2006, pp. 141-144.
} 
Diante disso, adotando-se um sistema preclusivo rígido no que tange ao tema da modificação da demanda, o conteúdo trazido pelo autor no ato introdutório deverá manterse constante até a decisão final, não se admitindo - ou se admitindo com pouca margem de manobra (como já dito alhures, com limites de variabilidade incertos) - as chamadas alterações da causa. ${ }^{108}$

Essa metodologia, porém, ao menos pela perspectiva adotada no presente trabalho, apresenta algumas incongruências com a realidade do conflito e assume uma perspectiva extremamente processual, desvinculada, muitas vezes, do plano substancial do direito e ignorando alguns dados importantes como a natureza apenas instrumental dos institutos processuais (no caso, causa petendi e petitum).

Salvo alguns poucos autores ${ }^{109}$, doutrina e jurisprudência, além de muitos legisladores - talvez por influência daqueles, incluindo aí o brasileiro ${ }^{110}{ }^{-}$, atribuem, nesse sentido, um caráter estático à demanda no processo, caráter esse gerado por um entendimento restritivo que atribui um perfil quase que absoluto aos dois "elementos objetivos", criando assim uma metodologia que, como se verá adiante, pode trazer mais prejuízos que benefícios.

Notou-se, outrossim, no estudo desenvolvido no capítulo precedente, que o tema da modificação da demanda, em geral, é abordado por uma perspectiva privatista. Em outras palavras, tal como dito, a modificação da demanda é abordada como ato das partes, sempre encarado como artimanha de uma delas para surpreender a outra e se beneficiar disso no curso do processo.

Surpresa, chicana processual, benefício conseguido por métodos ardilosos, dentre outras expressões, são elementos que permeiam a abordagem do instituto modificativo. Como se verá no desenvolvimento deste estudo, essa perspectiva deve sim ser levada em

\footnotetext{
${ }^{108}$ Para uma análise dos possíveis sistemas a ser adotado na fase introdutória, com interessante referência ao papel do juiz em cada uma delas e a modificação dos fatos e pedidos, TARUFFO, La trattazione della causa, cit., pp. 282-285.

${ }^{109}$ E aqui, além daqueles que encararam o tema por uma perspectiva epistemológica (GAMBA, Domande senza risposta, cit. pp. 148-202; ID, Diritto societario e ruolo del giudice, Padova, 2008, passim), pode-se citar como exceção, a despeito das premissas de identificação da demanda por meio dos três elementos, LuIgi Montesano, Dirito sostanziale e processo, in Riv. Trim. Dir. Proc. Civ., 1993, pp. 63 e ss.; ID., Limiti oggettivi di giudicato su negozi invalidi, in Riv. Dir. Proc., 1991, p. 60 e ss.; ID., Invocazione per la prima volta in appello dell'usucapione a fondamento di um'azione di revindica. Osservazioni in tema di "jus novorum" e di mutamento di "causa petendi" in appello, in Giur. Compl. Cass. Civ., 1948, I, pp. 112 e ss., que adota um conceito dinâmico da demanda.

${ }^{110}$ Vide capítulo 3.
} 
consideração. Contudo, não se apresenta como ponto principal do tema, tal como faz a maioria da doutrina e da jurisprudência, transformando-a em única forma de se encarar o argumento modificativo. Tomar a patologia do instituto como regra e, a partir daí, traçar considerações sobre ele parece, pelo menos pela ótica de quem escreve, um erro crasso que induz o estudioso a relegar a um segundo plano seus pontos positivos.

A má-fé e a surpresa gerada pela modificação da demanda (pequena face patológica, repita-se, do objeto desse estudo) podem ser contornadas pela técnica processual. O instituto da modificação, entretanto, deve ganhar uma nova perspectiva de abordagem, que pode e deve ser feita em conformidade com os escopos processuais que permeiam a nova visão instrumental de processo.

Nesse sentido, o presente trabalho buscará dar nova roupagem ao instituto, abordando-o como método de atribuição de qualidade à sentença, abandonando, pois, o enfrentamento privatístico do tema.

Esse é, em suma, o plano a ser seguido nos futuros três capítulos, bem como os problemas a serem enfrentados e as direções que serão seguidas.

\subsection{A demanda revisitada - nova perspectiva e abordagem.}

Esse item do capítulo, tal como o subtítulo sugere, tratará da demanda judicial partindo-se de uma nova perspectiva, qual seja, a epistemológica. Porém, antes de adentrar no tema de maneira técnica, algumas considerações de ordem geral, ainda que superficiais, deverão ser traçadas para um correto entendimento do raciocínio que aqui se pretende desenvolver.

Nesse sentido, deve-se remeter o leitor a um momento anterior à propositura da demanda e à instauração do processo em juízo. Faz-se referência, aqui, ao momento de formação da insatisfação do indivíduo (ou de um grupo de indivíduos) em relação a uma determinada situação da vida.

Para que possa ficar claro o conceito do termo 'insatisfação' - que mais adiante receberá uma nova roupagem técnica -, far-se-á remissão, apenas com fins didáticos, a um clássico da literatura internacional, qual seja: As aventuras de Robson Crusoé, de Daniel Defoe. Tal narrativa, além de instigante, estimula a proposição, se trazida ao campo do 
direito, de inúmeras perguntas e respostas que serão úteis à análise do tema objeto do presente estudo.

Trata-se, como é sabido por muitos, de uma história na qual um jovem, na Inglaterra de 1652, rumando contra todas as expectativas dos pais, lança-se à atividade náutica a fim de realizar a travessia dos mares. Ao que interessa para o raciocínio, Robson Crusoé, após entrar para a mercancia de escravos, torna-se vítima de um naufrágio, sendo obrigado a nadar até uma ilha que se supunha deserta, na qual viverá por vinte e sete anos. Ressalta-se que, passados quinze anos do acidente náutico, Robson descobre que não estava a sós, mas convivia, ainda que sem consciência, com nativos da ilha.

Feita essa rápida e panorâmica síntese da história, mas destacando o essencial para o raciocínio que se pretende desenvolver, pode-se, agora, aproximar o personagem principal da obra ao direito, tal como fora proposto anteriormente.

Robson Crusoé, ao chegar à ilha aparentemente deserta, tinha à sua disposição todos os bens necessários à sua sobrevivência (baseando-se, claro, em uma vida simples); animais, plantas e os demais recursos do local estavam todos à sua disposição. Podia Crusoé, desse modo, dispor como bem entendesse daquilo que estava ao seu alcance. O exercício de imaginação até mesmo autoriza a pensar que se o personagem desejasse destruir toda a ilha no momento em que pisou em solo firme, mesmo que isso o prejudicasse, poderia, em termos genéricos e sem qualquer juízo moral, fazê-lo afetando diretamente tão só a si mesmo.

Porém, quando se adiciona ao desenvolvimento da história os nativos daquele local, as afirmações acima mudam de perspectiva. Robson Crusoé, agora, não mais dispõe e usufrui livremente dos bens ali presentes. Isso ocorre pelo fato de que outros indivíduos dependem, tal como ele, daqueles elementos para suas sobrevivências. Qualquer conduta, seja do personagem principal seja dos nativos, afetará diretamente a esfera de interesse dos demais.

Evidentemente que se pode imaginar situação na qual há a imposição da vontade de um (ou alguns) aos demais por meio da força, ou mesmo o fato de um (ou alguns) ignorarem a presença dos outros e agir como se sozinho estivesse. Independentemente das variações situacionais possíveis, fato é que a presença dos demais e a conseqüente relação das necessidades dos indivíduos com os bens disponíveis alteram a perspectiva das análises feitas quando Robson Crusoé encontrava-se isolado, quando estava só na ilha. 
Deixando a literatura de lado, mas utilizando o raciocínio ali desenvolvido, podemse trazer as observações para o campo do direito. Os fenômenos ali destacados não passaram despercebidos pela doutrina em geral, bem como foram objeto de estudos, em específico, pelos processualistas.

Observando a relação entre bens e necessidades, a doutrina processual clássica desenvolveu o conceito de interesse. Tal termo está relacionado diretamente com a noção de necessidade. Interesse, no sentido técnico-doutrinário ${ }^{111}$, é, pois, a relação entre uma necessidade do homem e algo apto a satisfazê-la. Esse algo se chama bem, podendo ser material ou imaterial, físico ou pertencente ao plano dos sentimentos. Logo, homem e bem são dois pólos de uma relação denominada interesse.

Quando há pluralidade de interesses e escassez do bem relativo a eles, desaguando, portanto, na impossibilidade de, simultaneamente, serem as necessidades satisfeitas - e, em geral, essa é a regra - há um conflito entre esses interesses. Nota-se, nesse sentido, que os choques de interesses dessa natureza são intrínsecos a uma sociedade ou um agrupamento de pessoas. Onde há dois ou mais indivíduos, com limitações de bens aptos a satisfazerem suas necessidades, há aí conflitos de interesses em termo técnico.

Porém, ante a essa situação, pode um indivíduo (ou conjunto de indivíduos) submeter seu interesse em favor dos demais. Em outros termos, um dos sujeitos pode abrir mão de obter o bem para satisfação de sua necessidade em favor de outrem. Podem, por outro lado, ambos (ou todos, a depender do caso) os envolvidos cederem em parte em relação a um determinado bem e equilibrar os interesses em um ponto de estabilidade. A exigência de subordinação de um interesse alheio ao interesse próprio é denominada pela doutrina como pretensão. ${ }^{112}$

Em todas as situações narradas inexistem, em tese, insatisfações dos indivíduos, estando mantido o equilíbrio social.

111 "La nozione fondamentale per lo studio del diritto è la nozione di interesse. Questa è a sua volta strettamente legata alla nozione di bisogno; interesse è appunto um rapporto tra um bisogno dell'uomo e un quid atto a soddisfarlo (...) I mezzi per la soddisfazione dei bisogni dell'uomo sono i beni. Se interesse è la situazione di un uomo favorevole al soddisfacimento di um bisogno, questa situazione si verifica dunque rispeto a un bene: uomo e bene sono i due termini del rapporto, che noi chiamiamo interesse", assim CARnelutti, Lezioni di Diritto Processuale Civile, Padova, 1931, v. I, p. 3.

112 CARnelutTI, Instituciones del proceso civil, Sentís Melendo (trad.), Buenos Aires, 1950, vol. I, p. 28. Para uma análise crítica quanto aos diversos e homogêneos usos do termo pretensão, ver: DINAMARCO, Instituições, II, cit., pp. 107-108. 
Ocorre, porém, que nem sempre um ou mais sujeitos estão dispostos a ceder em relação aos seus interesses, quer em parte deles ou em sua totalidade. Quando isso ocorre, há o que a doutrina chamou de pretensão resistida, ou, em termos mais conhecidos, de lide. ${ }^{113}$

Não cabe, pelo menos nesse momento, esmiuçar as diversas polêmicas sobre os conceitos de lide traçados pelos processualistas ${ }^{114}$. Tal debate, ainda que tangencialmente, será enfrentado em sede própria. Para o momento, porém, destaca-se o fato de que as insatisfações dos indivíduos surgem em momento anterior à propositura da demanda, como é óbvio, e são oriundas das relações entre indivíduos e indivíduos e bens, relações essas inerentes a uma sociedade ou agrupamento de pessoas. O fenômeno da insatisfação é, pois, antes de jurídico, sociológico.

Ademais, dando passos avante no que aqui se pretende desenvolver, ressalta-se o fato de que, em um cenário em que interesses estão constantemente em conflito, para que haja uma mínima possibilidade de harmonia na convivência entre os indivíduos, necessária se faz a observância de normas que definam quais interesses devem se submeter, ainda que em contrariedade à pretensão de seu titular, ao interesse alheio.

Dentre essas normas é possível encontrar aquelas de cunho social, moral, religioso, enfim, preceitos de variadas naturezas que dispõem sobre os seres e coisas, sempre com o fim de manter e/ou estabelecer a ordem. ${ }^{115}$

Algumas dessas relações entre os indivíduos, pelo objeto que possuem, são de interesse de regulamentação pelo Estado. Não cabe nessa seara entrar no debate quanto à formação das leis e suas nuances. Entretanto, o que se pode afirmar é que, por meio de sua atividade legislativa, permeada por interesses ideológicos e políticos, o Estado cria normas

${ }^{113}$ CARNELUTTI, que foi quem se ocupou com maior afinco do tema da lide, buscando limites claros à palavra de significado impreciso, diferencia a lesão da contestação do interesse, ambas hipóteses de resistência à pretensão. Desse modo, afirma que "esistere la lite quando taluno pretende la tutela di un suo interesse in contrasto con l'interesse di um altro e questi vi resiste mediante la lesione dell'interesse o mediante la contestazione della pretesa", Lite e funzione processuale, in Riv. dir. proc. civ. 1928, p. 29; ID, Instituciones, cit., p. 28.

114 Faz-se referência aqui, em especial, ao celebre debate entre CALAMANDREI, Il concetto di 'lite' nel pensiero di Francesco Carnelutti, in Rev. dir. proc. civ., 1928, pp. 3-22 (versão em espanhol El concepto di 'litis' em el pensamiento di F. Carnelutti, in Estudios sobre el proceso civil, Sentís Melendo (trad.), Buenos Aires, 1945, p. 265-294), e CARNELUTTI, Lite e funzione, cit., pp. 21-37.

115 Nas palavras GOFFREDo TELlES JUNIOR, buscando uma definição genérica de lei, afirma: "Estes princípios ou preceitos (ou "receitas") constituem as fórmulas segundo as quais os seres são dispostos, ou devem ser dispostos, para que a ordem exista. São formas abstratas, segundo as quais se realiza, em cada caso concreto, 'a unidade do múltiplo’”, Iniciação na Ciência do Direito, São Paulo, 2006, p. 31. 
que submetem alguns interesses a outros, isto é, atribui ao detentor do interesse que deve 'sobreviver' uma posição de vantagem frente àquele que teve seu interesse 'preterido'.

Essas observações de cunho geral, embora não tenham o condão (nem, tampouco, a intenção) de exaurir esse vasto tema, são suficientes para que se possa destacar a existência de um determinado grupo de regras que compõem o chamado direito material (ou, em outros termos, direito substancial). Tais regras, como já destacado, servem para regular a vida entre as pessoas em certo lugar e tempo.

Quando essas regras não são observadas pelos seus destinatários espontaneamente ${ }^{116}$, o Estado se vale de um grupo de regras e princípios "que regulam o exercício da jurisdição, da ação, da defesa e do processo"117. Desse modo, as normas que buscam colocar em prática as regras materiais, resolvendo a crise surgida nesse plano, chamam-se regras de direito processual.

O processo é, pois, um método de trabalho do Estado que tem como escopo precípuo a pacificação social, resolvendo as crises do direito material ao atribuir o bem da vida ao indivíduo titular do interesse tutelado. ${ }^{118}$

Visto isto, fazendo-se uma espécie de síntese do que foi dito até aqui, ressaltam-se elementos de grande importância. O primeiro deles é que a insatisfação dos indivíduos nasce da escassez dos bens. Há, quando um determinado bem não é capaz de satisfazer várias necessidades simultaneamente, um conflito de interesse entre os sujeitos envolvidos. Um desses interesses, segundo as normas existentes, deve ser 'sacrificado' - em sua integralidade ou em parte - em benefício do outro concorrente.

Quando um indivíduo (ou conjunto de indivíduos) acredita que seu interesse deva prevalecer e o outro concorrente se submeter (pretensão), mas a efetivação dessa crença

\footnotetext{
${ }^{116}$ Existe também o processo da chamada jurisdição voluntária ou, como prefere alguns, graciosa. Para estes casos, entende-se que o processo se presta a resolver um conflito em sentido lato, isto é, uma insatisfação não configurada como lide. Mesmo assim, consiste em situação que exige a observância das normas processuais para se atingir a efetivação no plano concreto das regras materiais.

${ }^{117}$ BEDAQUE. Direito e Processo, cit., p. 11.

118 Nas palavras de DiNAMARCO: "Processo civil é, resumidamente, técnica de solução imperativa de conflitos”, Instituições de Direito Processual Civil, v. I., São Paulo, 2009 p. 37. Cabe aqui relatar que o mesmo autor traz algumas acepções para o vocábulo processo: $\mathrm{O}$ institucional, processo como método de trabalho, além de processo como "realidade fenomenológica da experiência dos juízes e das partes em relação a cada um dos incontáveis conflitos entre pessoas ou grupos, concretamente trazidos ao Estado-juiz em busca de tutela jurisdicional”, Instituições de Direito Processual Civil, v. II, São Paulo, 2009, pp. 23-25.
} 
esbarra na conduta de resistência do titular deste último, tem-se aí, em sentido sociológico, uma insatisfação. ${ }^{119}$

Tal insatisfação, dependendo de sua natureza, pode ser solucionada pelo método de trabalho estatal chamado processo. Em outras palavras, sendo vedada, em regra, a autotutela e não havendo autocomposição, deve o indivíduo procurar o Estado para solucionar a crise. $\mathrm{O}$ ato de pedir uma solução para seus problemas práticos, em termos processuais técnicos, se chama demanda. Demandar, pois, é pedir uma tutela jurisdicional, instrumentalizada, em geral, por meio de um ato escrito chamado petição inicial. ${ }^{120}$

Disso, algumas observações devem ser destacadas: a primeira delas é que as insatisfações levadas a juízo, antes de serem jurídicas, são fenômenos sociais, nascentes de relações intersubjetivas inerentes a um agrupamento de pessoas. $\mathrm{O}$ sujeito que pretende ver seu interesse satisfeito e busca a via processual não está diretamente interessado no que ocorre em juízo, mas sim nos efeitos práticos relativos ao bem que esse método pode lhe trazer. Para o envolvido, o que realmente tem relevância é a solução favorável da crise existente em sua vida.

Ademais, tais insatisfações, como não poderiam deixar de ser, nascem, invariavelmente, de fatos. Fatos esses que podem ser eventos da natureza, ações humanas, comportamentos, condutas, enfim, qualquer acontecimento observável no plano fenomênico que tenha alguma relevância. Claro, porém, que, para que se possa utilizar o processo como método de resolução do conflito, estes fatos devem possuir relevância jurídica, aferível a posteriori por algum operador do direito ${ }^{121}$. Todavia, essa ressalva não anula a natureza sociológica primária das insatisfações e sua origem em fatos.

\footnotetext{
${ }^{119}$ Ao tratar dos reflexos das insatisfações no âmbito social, DINAMARCO afirma que "psicologicamente, às vezes a privação consumada é menos incômoda que o conflito pendente: eliminado este desaparecem as angústias inerentes ao estado de insatisfação e esta, se perdurar, estará desativada de boa parte de sua potencialidade antissocial", Instrumentalidade do processo, São Paulo, 2009, pp. 190-191.

${ }^{120}$ Diz-se, em geral, por haver no sistema métodos de demandar (pedir) oralmente (LJE, art. 14). Para aprofundamentos sobre demanda e petição inicial, ver: DINAMARCO, Instituições, II, cit. pp. 108-109.

121 A vida prática do foro mostra que não é raro indivíduos buscarem consultas de advogados e, após exporem suas insatisfações e narrarem os fatos que lhe deram origem, verificarem que aquela celeuma não passa de aborrecimentos quotidianos - termo muito usado no meio jurídico - e que não seria recomendável a propositura de uma demanda para solucioná-la. Sobre controvérsias que não deveriam ser levados a juízo, TARUfFo, Processo civil e litigiosità, in (estratto) Scritti in Onore di Mario Vellani, tomo II, pp. 803 e ss. Para uma análise sobre a relação entre advogados, clientes e fatos, ver MARIO ERNESTO KAMINKER, Reflexiones sobre hechos, pruebas, abogados y jueces, in Rev. Peruana de Derecho Procesal, jun/2002, pp. 130-133.
} 
Conclui-se disso que a roupagem jurídica da crise e dos fatos é um fator que somente será adicionado no momento da formulação do ato introdutório do processo por um profissional do direito. Tal fase será analisada pormenorizadamente adiante, não cabendo aqui maiores aprofundamentos. Destaca-se, entretanto, que o fenômeno sociológico e concreto é 'enquadrado' em moldura jurídica sem que isso o faça perder suas características iniciais. Ao contrário, a elas apenas são adicionadas novos elementos de caráter legal.

Feitas essas observações de ordem geral, pode-se passar para a análise da demanda em termos técnicos. E, para tanto, o presente estudo prosseguirá dividido em três subitens: um destinado aos fatos, o segundo destinado às qualificações jurídicas desses fatos e, por fim, aos pedidos formulados. Essa divisão se dará por duas razões: a primeira é de ordem legal, já que os dispositivos que tratam da demanda assim exigem que seja o ato introdutório (fatos e fundamentos jurídicos como requisitos da inicial); a segunda, por seu turno, é devido ao fato de que causa de pedir e petitum, chamados elementos objetivos da demanda, são os dois institutos usados pela maioria da doutrina para o tratamento do tema. Logo, fundamental rever a demanda e seus elementos por uma perspectiva diversa, mas 'paralela' com o que até aqui foi traçado. Ademais, um terceiro e último motivo relacionase com o que foi até aqui exposto: as crises são originadas dos fatos, dos acontecimentos do quotidiano dos indivíduos, e resolvidos, em grande parte, por um método estatal e jurídico chamado processo; logo, a exposição da circunstância fática fonte da insatisfação, bem como uma requisição de solução para a insatisfação manifestada justificam o método.

É o que se passa a fazer.

\subsection{Das narrativas em geral}

Como foi dito no item precedente, um dos requisitos para a propositura de uma demanda é que o autor descreva em sua peça inicial os fatos dos quais originou sua insatisfação. Viu-se, outrossim, que a estrutura dessa exigência é intrínseca ao conflito, que

sempre se origina das situações da vida quotidiana, tendo o legislador processual obedecido a uma regra lógica ao requisitar a exposição dos fatos como elemento da inicial. 
Ocorre, todavia, que a citada exigência, muitas vezes, é abordada pela doutrina de forma generalizante e superficial. Na realidade, os estudiosos do processo, ao tratarem dos fatos da demanda, preocupam-se em qualificá-los e enquadrá-los nas categorias processuais tradicionais de causa de pedir (tais como remota, próxima, ativa, passiva, fato principal, secundário etc,), deixando em um segundo plano (ou mesmo se olvidando) de uma fase precedente a esta, mas de importância fundamental, qual seja, o momento e a forma com que os fatos são 'trazidos' ao processo pelos sujeitos nele atuantes.

Em outros termos, a doutrina volta toda sua atenção e todo seu esforço no sentido de responder a questões como: qual a posição funcional do fato na demanda? Para que ele serve? Ele é apto a individuar a causa em debate ou apresenta apenas importância secundária? Qual sua importância para a pretensão do autor? Dentre tantas outras. Porém, deixa de se perguntar, por exemplo, se os fatos são mesmo fatos - entendidos como acontecimentos naturalísticos - ou apenas narrativas fáticas formuladas por alguém. Dessa maneira, não se questionam qual seriam a natureza dessas assertivas e suas peculiaridades? Como elas são formuladas e, posteriormente, 'entram' no cenário processual? ${ }^{122}$

Que as questões ora propostas são temporalmente precedentes àquelas tradicionalmente formuladas pela doutrina, não há dúvidas. Entretanto, neste momento, necessário será demonstrar que elas apresentam importância ímpar para o deslinde do trabalho e que são fundamentais para o correto enfrentamento do instituto da modificação da demanda.

Parte-se, para tanto, de uma observação que, outrossim, parece longe de questionamentos: não são fatos que são trazidos ao processo, mas narrações sobre os fatos formuladas por aqueles que agem no processo $^{123}$. No que tange ao ato introdutório, em específico, exige a lei, pois, que o autor formule suas narrativas judiciais. Em um primeiro

${ }^{122}$ Ao tratar da causa petendi, MOREIRA PINTO assim se expressa: "A causa petendi é composta pelo fato e pelo fundamento jurídico. E tendo com base estes integrantes, vem a doutrina classificando a causa de pedir em causa remota e causa próxima. A causa petendi remota engloba, normalmente, o fato constitutivo do direito do autor associado ao fato violador desse direito. Trata-se da relação fático-jurídica existente entre as partes. Por outro turno, a causa petendi próxima está representada no enquadramento da situação concreta, narrada in status assertionis", A causa de pedir e o contraditório, cit., pp. 19. No mesmo sentido, encarando fatos como dados absolutos sem questionamentos quanto a natureza dos enunciados, MILTON PAULO DE Carvalho, Pedido novo e aditamento do pedido. O art. 294 do Código de Processo Civil na sua nova redação, in Cruz e Tucci (coord.), Processo Civil - Evolução - Vinte anos de vigência, São Paulo, 1995, p. 174 e ss.

${ }^{123}$ GAMBA, Diritto societario e il ruolodel giudice, Padova, 2008, p. 400. TARUFFO, Prova (in generale), in (estratto) Digesto, vol. XVI Civile, Torino, 1997, pp. 3 e ss.; ID., Prova giuridica, in (estratto) Enc. dir., Annali, vol. I, Milano, 2007, pp. 1016 e ss. 
momento essa afirmação não parece apresentar maiores problemas. Contudo, o tema traz algumas dificuldades que devem ser enfrentadas, bem como alguns pontos importantes que devem ser ressaltados para uma correta abordagem do conteúdo das manifestações no processo.

Em primeiro lugar, deve-se aqui destacar que o termo narrativa, durante as últimas duas ou três décadas, ganhou grande relevância ${ }^{124}$, destacando-se como tema de interesse das mais diversas áreas do conhecimento, tais como a literatura, filosofia, além, é claro, das ciências jurídicas. O uso demasiado dessa palavra fez com que seus limites conceituais se tornassem nebulosos. Mais especificamente, a palavra narrativa, tomada por diversas perspectivas de estudo, ganhou um ar de vulgarização, levando o termo a um lugar comum que gera dificuldades, inclusive no que concerne ao objeto desse estudo.

Falar em narrativas exige, deste modo, algumas observações iniciais para que se possa entender qual a perspectiva que será adotada para o termo durante o desenvolvimento do raciocínio. Em outras palavras, necessária se faz a definição dos contornos que irão tornear a expressão.

Pode-se afirmar que entre as narrativas judiciais e story-tellings há uma conexão. Pode-se assumir que as histórias contadas no processo pelos sujeitos são, sem nenhum problema, narrações ${ }^{125}$. Entretanto, para tratar das narrativas judiciais, importante abandonar alguns debates que, segundo TARUFFO, atualmente são triviais e extemporâneos, tais como aqueles relativos aos ataques pós-modernos aos "Grandes Relatos" e o contraste entre "fundacionalistas" e "antifundacionalistas". ${ }^{26}$

Ademais, deve-se ressaltar que o tratamento das narrativas judiciais fazendo-se referência aos relatos quotidianos e concentrá-los no âmbito jurídico, tal como se posiciona o movimento "Direito e Literatura" ${ }^{127}$, é insuficiente para uma abordagem satisfatória e útil do argumento. ${ }^{128}$

\footnotetext{
${ }^{124}$ Para alguns autores que se dedicaram ao tema, relevância essa exagerada. Assim, TARUFFO, Narrativas Judiciales, in Revista de derecho, 2007, p. 233.

125 TARUFFO, ibidem.

${ }^{126}$ Para maiores aprofundamentos em relação ao debate citado, ver MiNDA, Postmodern Legal Movements. Law and Jurisprudence at the Century's End, New York-London, 1995, p. 161. Para algumas breves críticas, TARUFFO, Narrativas, cit., p. 234.

127 Como referência do movimento na literatura nacional, ver a obra coletiva Direito e literatura: da realidade da ficção à ficção da realidade, KARIM TRINDADE e STRECK (coord.), São Paulo, 2013, passim.
} 
Feitas essas ressalvas e afastando as visões citadas, em prosseguimento ao raciocínio que aqui se quer desenvolver, anota-se que as histórias, tanto no âmbito judicial como em esfera geral, segundo doutrina empenhada no estudo do tema, possuem duas características fundamentais, quais sejam: elas são necessárias e, ao mesmo tempo, perigosas. $^{129}$

As histórias e narrações são necessárias pelo simples fato de que é por meio delas, principalmente, que informações e 'pedaços dos acontecimentos' formam, depois de reunidos e organizados, um conjunto de suposições coerente e significativo capaz de nos dar um esquema de mundo. São, em outras palavras, elaborações interpretativas dos acontecimentos que compõem uma série de dados. Nas palavras de TARUFFO, "ellas proveen una 'heurística', esto es, un método para descubrir lo que realmente ocurrió". ${ }^{130}$

Por outro lado, sem que se faça nesse momento uma análise profunda do argumento que será tratado pormenorizadamente adiante, nota-se que as narrativas são perigosas devido ao fato de que dão ensejo à vagueza e a variabilidade, além da manipulação dos acontecimentos a depender do interesse do narrador, de seu ponto de vista, de sua interpretação do fenômeno e de seus objetivos ao traçar as narrações, do momento e do contexto em que formuladas, da capacidade técnica e de observação daquele que conta a história. Enfim, as narrações sobre os mesmos acontecimentos ficam à mercê de uma série de variáveis internas e externas.

Em um contexto judicial, tais observações são bastante relevantes, já que as narrações feitas pelas partes são necessárias (não só por exigência legal, como se viu), mas também variáveis, incompletas, fruto das interpretações dos acontecimentos pelas próprias partes e por seus advogados, confeccionadas por sujeitos interessados em defender seus

Para especificações no âmbito internacional, Minda, Postmodern, cit., 149 e ss; MARTíneZ MARTínEZ, Literatura y derecho, Ciudad de Mexico, 2010, passim.

${ }^{128}$ Em crítica incisiva ao movimento Direito e Literatura, TARUFFO afirma que embora ele tenha dado muitas luzes aos assuntos jurídicos, deu também "mucha chácara académica para la hora del cóctel. No todo lo que se dice resulta significativo, em realidad, y cuando lo es se refiere principalmente a ideas vagas y variables sobre 'narrativas jurídicas' em las que la distinción entre hechos y derechos normalmente es difusa y los 'hechos judiciales' se mezclan en una indistinta 'conversación literaria sobre el derecho'”, Narrativas, cit. p. 234.

129 TwINING, Rethinking Evidence, Exploratory Essays, Cambridge, 2006, p. 336.

${ }^{130}$ Narrativas, cit. p. 235. No mesmo sentido, exaltando o mesmo aspecto, ARTHUR KAUFMANN, Diritto $e$ linguaggio, in Filosofia del diritto ed ermeneutica, a cura di Marino, Milano, 2003, pp. 175, 177 e 178. 
pontos de vistas parciais. Ignorar esses elementos pode ser - e na maioria das vezes tem sido - um grande erro dos juristas.

As especificidades das narrativas no âmbito do processo serão tratadas no item sucessivo. Contudo, ressalta-se que tanto a necessidade quanto o perigo são características gerais aplicáveis a elas e que não devem ser olvidadas ao analisar as 'histórias' trazidas pelos sujeitos processuais. Ao encarar os fatos apresentados no processo, pois, deve se levar em conta que não se tratam de fatos em si mesmos, como fenômenos naturalísticos, mas de assertivas, narrações, histórias que, como dito, são incompletas, variáveis, parciais, frutos de interpretação do narrador.

É considerando esses pormenores que se pretende analisar os fatos na demanda.

Além disso, como se sabe, várias são as formas possíveis de narração dos fatos. Novelas, contos, autos, poemas, enfim, todas são maneiras de referir-se a acontecimentos com mais ou menos rebuscamento artístico. As que mais interessam para o trabalho são, sem dúvida, aquelas redigidas na forma de relatos históricos, pois essa é a maneira que as narrativas fáticas entram no processo. ${ }^{131}$

O tema, em uma primeira impressão, parece ser pacífico e claro, sem maiores debates. Ocorre, porém, que por trás da narração estão escondidos inúmeros aspectos epistemológicos que não são tão simples quanto parecem. Diante disso, para tratar da narrativa no processo pela perspectiva que se entende correta, deve-se, nesse momento, destacar algumas outras características típicas dos relatos em geral, aplicáveis, como não poderia deixar de ser, aos relatos judiciais formulados pelas partes. ${ }^{132}$

Nesse sentido, para facilitar a visualização das características gerais aludidas, tomase como objeto de análise um relato literário (exemplo escolhido dentre tantos outros possíveis no universo das narrativas). Nele, pode-se constatar que o narrador faz, com intuito de atribuir veracidade, coerência e realismo à sua história, menção a lugares, a situações, a personagens, enfim, a elementos que realmente possam existir ou que em

131 Para aprofundamentos sobre os complexos debates e os meandros da narratologia, ver TWINING, Rethinking Evidence, cit., pp. 6 e ss. Para um posicionamento com críticas, ver FARBER e SHERRY, Telling Stories Out of School. An Essay on Legal Narratives, in 45 Stanford Law Review, 1993, pp. 806 e ss.

${ }^{132}$ As características das quais se fala são trazidas com maiores aprofundamentos por TARUFFO, La semplice verità. Il giudice e la costruzione dei fatti, Bari, 2009, pp. 36 e ss., obra na qual o professor de Pavia, com didática clara e precisa, recorre ao conto The Broker, de John Grisham, passado em Bolonha, para destacar os elementos que aqui interessam; nesse mesmo caminho, ver ID., Considerazioni su prova e verità, in Sui Confini, Bolonha, 2002, p. 277 e ss. 
algum momento existiram. Algumas dessas asserções por ele formuladas, pois, podem encontrar reflexo na realidade material daquilo que é descrito. Por outro lado, por se tratar de uma história literária, outros enunciados fáticos podem relatar situações inexistentes, isto é, não verificáveis no plano fenomênico.

Considerando o espaço amostral dos indivíduos que conhecem a hipotética obra, há aqueles que já estiveram no local narrado ou vivenciaram as situações da história. Por seu turno, há também aqueles que nunca estiveram lá ou jamais viveram as experiências ali narradas. Os primeiros, para os fins do estudo, serão tratados como leitores informados (LI), ao passo que os segundos serão os leitores não informados (LNI). ${ }^{133}$

Partindo dessa diferenciação, nota-se que as posições dos dois tipos de leitor se distinguem quanto a alguns pontos da narrativa. O LI é capaz de, dentro da história, distinguir os relatos em três espécies epistemicamente distintas. São elas: a) os enunciados verdadeiros, que são as asserções feitas que conferem com a situação concreta da realidade; há, nessa espécie, uma compatibilidade empírica do que se narra e o que se nota no plano fenomênico; b) os enunciados falsos, porém verossímeis, que são aqueles não compatíveis com a realidade, mas relativos a fenômenos que normalmente acontecem; acontecimentos que, pela experiência humana, são observáveis com freqüência no quotidiano dos indivíduos ${ }^{134}$; e c) os enunciados falsos que não possuem a pretensão de serem verdadeiros, enunciados estes relativos a acontecimentos fantásticos, visivelmente não existentes, que servem, muitas vezes, para enriquecer o relato literário.

Entretanto, se tomada a posição epistêmica do LNI, verifica-se que ele somente é capaz de identificar enunciados verossímeis e enunciados falsos sem pretensão de serem verdadeiros. O LNI, pela sua perspectiva, não pode, por ausência de conhecimento, reconhecer os enunciados do tipo verdadeiro, além de não poderem diferenciar, dentro dos enunciados verossímeis, aqueles reais e daqueles irreais.

Pela perspectiva da lógica e da coerência da história, não há diferença entre a posição de ambos os tipos de leitores: todos os dois poderão igualmente apreciar as

\footnotetext{
${ }^{133}$ A nomenclatura é de TARUFFO, ibidem.

${ }^{134}$ Verossimilhança não se confunde com verdade. Em definição de verossimilhança, TARUFFO afirma: “In sostanza, è verossimile cio che corrisponde all'id quod plerum que accidit: se solitamente un certo evento si verifica con certe modalità in un certo giorno della settimana, è verossimile che lo stesso evento si verifichi in un futuro o si sia verificato in passato in quel giorno della settimana”, La semplice verità, cit., p. 88.
} 
narrações e os acontecimentos. Contudo, epistemicamente LNI e LI lêem a mesma narração de pontos de vistas distintos. ${ }^{135}$

Embora o assunto seja objeto de reflexões futuras, destaca-se que as posições epistemológicas acima identificadas podem ser notadas no âmbito do processo judicial. Juiz, advogados e partes, ante a crise trazida a juízo, podem ser equiparados, nos mais variados momentos processuais, aos LNI e LI. ${ }^{136}$

Outro ponto importante que se extrai da análise acima é que os enunciados falsos sem pretensão de veracidade são aceitos no mundo da literatura e da fantasia. Entretanto, o mesmo não acontece no cenário judicial. A afirmação de que "no fundo do mato-virgem nasceu Macunaíma, herói de nossa gente" é perfeitamente compreensível se lida na obra de Mário de Andrade, mas completamente estranha se encontrada no bojo de uma petição inicial.

As razões para isso são simples: ao ler Macunaíma o indivíduo suspende sua incredulidade por estar consciente de que se trata de arte, na qual não se espera que os relatos sejam verdadeiros. Aliás, suspender a incredulidade para apreciar obras artísticas pode ser essencial para um desfrute intenso. Diferentemente ocorre quando se lê relatos judiciais referentes a fatos que dão sustentação a um suposto direito, nos quais as histórias não devem ser só verossímeis, mas também verdadeiras para que atinjam os seus fins. ${ }^{137}$

\footnotetext{
135 Taruffo, Narrativas, cit. p. 237.

${ }^{136}$ Como exemplo dos impactos práticos dessas posições no âmbito processual, pode-se invocar a crítica de MiCHELE TARUFFO quanto às reformas da fase de 'trattazione della causa' pela Lei $\mathrm{n}^{\circ} 354$ de 1995 . Tal lei não alterou substancialmente o sistema precedente da audiência de trattazione (que passou não mais a ser a primeira, mas sim a segunda, haja vista a existência de uma audiência anterior de comparizione). Uma das modificações foi a exigência do comparecimento pessoal das partes - antes dependente de suas livres iniciativas ou de ordem judicial-, sob pena de o juiz, em caso de ausência de uma ou ambas as partes, poder requerer provas sem pedido dos sujeitos parciais no sentido do art. 116 do CPC italiano. Entretanto, essa exigência poderia ser mitigada por uma autorização legal na qual a parte poderia fazer-se representar por seu procurador. Surge, com isso, um grande problema referente aos "fatos do processo" e a posição epistemológica dos indivíduos: admitir que o defensor possa se submeter ao livre interrogatório no lugar de seu cliente significa admitir que seja suficiente o conhecimento apenas indireto dos acontecimentos postos à base do conflito. O advogado é, como se nota, simplesmente um LNI. O livre interrogatório - destinado a esclarecer e clarear o cenário factual - é útil tão somente se tiver como interrogado alguém que teve contato direto com os fatos, isto é, as partes, que possuem posições de LIs. No caso da exceção legal, o advogado somente poderá reproduzir o que já havia escrito, sem que possa acrescentar algo de substancial ao órgão julgador. Nesse sentido, La trattazione della causa, cit. pp. 293-294.

137 "El contexto judicial es un contexto en que la verdad empírica es necesaria; una novela es un contexto en cual la 'verdad narrativa' es simplemente algo que pertence al mundo fantástico creado por el novelista", TARUFFO, Narrativas, cit., p. 238.
} 
Não se está fazendo aqui, destaque-se, referência à obrigatoriedade ou não das partes dizerem a verdade em juízo. Esse debate, a despeito de interessante e importante, foge aos limites do presente estudo. Ao se afirmar que enunciados fantásticos não são apropriados para relatos judiciais está-se, isso sim, suscitando outro ponto epistemológico importante dos enunciados em geral, qual seja, a relação entre a sua veracidade e os efeitos dessa veracidade num determinado contexto.

No contexto judicial, como é intuitivo, busca-se apresentar fatos (rectius: enunciados sobre os fatos) que sustentem uma tese favorável ao narrador. Desse modo, aquele que narra seleciona os acontecimentos interessantes ao ponto de vista defendido e os exprime buscando uma tomada de perspectiva que lhe favoreça. Os enunciados formulados são, desse modo, apofânticos, isto é, podem ser verdadeiros ou falsos, sendo verificáveis ou não no mundo da experiência concreta ${ }^{138}$. Contudo, para que produzam os efeitos desejados e se chegue à conclusão da tese defendida, os indivíduos responsáveis pelas assertivas fáticas devem - se pretendem comportar-se racionalmente - estabelecer com a máxima certeza a veracidade daquilo que fora narrado. Desse modo é que enunciados falsos sem pretensão de serem verdadeiros não condizem como o contexto processual.

Ao se falar em contexto, surgem algumas outras breves considerações importantes sobre as narrativas em geral e seus enunciados, observações essas que também terão relevância mais adiante para o objeto desse estudo. Tais considerações referem-se ao significado da enunciação e sua relação com o contexto em que inserido, ou seja, da parte com o todo.

Quanto ao ponto, é de se destacar, por primeiro, que cada enunciado fático deverá necessariamente ser interpretado por aquele que o toma como destinatário. Entretanto, sua significação se dá dentro de um determinado contexto, podendo ela ser alterada se trasladado o enunciado a um âmbito circunstancial distinto. Ao se afirmar, por exemplo, que a bolsa de valores norte americana teve forte queda em março de 2014 (enunciado tirado aleatoriamente dentre infinitos possíveis), está-se fazendo uma assertiva na qual seu significado deve ser determinado dentro de um contexto de conhecimento sobre mercado de capitais e economia dos Estados Unidos, bem como de conhecimento técnico quanto às

${ }^{138}$ TARUFFO, Considerazioni, cit. p. 277; GAMBA, Diritto societario, cit., pp. 406, 116-117. Para relação do ato lingüístico e seu contexto, ClAUdia CAFF, Illocuzione, metacomunicazione, coinvolgimento. Problemi teorici di pragmatica linguistica, Pavia, 1990, p. 12. 
possíveis conseqüências financeiras e monetárias do evento. A mesma assertiva pode ter outro significado se colocado dentro de um contexto jurídico. Sua relevância passa a ter novos contornos se encontrada no bojo processual, agora determinada por contexto normativo-legal e possuindo conseqüências jurídicas se colocada à base de uma demanda.

Em outros termos, é do contexto dentro do qual está inserido um determinado enunciado fático que se extrai seu exato significado e relevância. Mais adiante serão traçadas considerações específicas sobre os enunciados de fato, seus significados e sua relevância dentro de um cenário processual. Porém, destaca-se desde já que, também eles, tais como quaisquer outros enunciados em geral, são context-laden. ${ }^{139}$

Somado à dificuldade interpretativa contextual acima descrita, surge outro ponto a ela relacionado que é freqüentemente destacado pela doutrina da linguagem. Trata-se das variações interpretativas pessoais que cada um faz do mesmo enunciado. Além da mudança de relevância causada por uma alteração de circunstância (de contexto), um mesmo enunciado pode ser interpretado dentro de um mesmo cenário de variadas formas, sempre a depender dos indivíduos que o lê. ${ }^{140}$

É bem verdade que essas observações não devem ser tomadas de forma extrema. Sabe-se que a linguagem se cria e se desenvolve em um âmbito interpessoal, gerando uma experiência comum que atribuí às palavras um "significado médio". Negar tal fato desaguaria fatidicamente na impossibilidade de uma comunicação mínima. Entretanto, não se pode olvidar que as interpretações dos enunciados dependem necessariamente da bagagem cultural de cada um, que podem ser mais ou menos homogêneas dentro de uma determinada comunidade.

Desse modo, verifica-se que a narração feita pelas partes dentro do processo não pode e não deve ser tida como algo unívoco. As assertivas fáticas são passíveis, pois, de diversas interpretações, que são, ainda que com pouca variação, diferentes entre si. ${ }^{141}$

\footnotetext{
${ }^{139}$ Nesse sentido, com aprofundamentos e ampla bibliografia sobre a contextualização epistemológica, ver TARUFFO, Prova (in generale), in (estrato) Digesto, vol. XVI civile, 1997, p. 4.

${ }^{140}$ KAUFMANN, Diritto e linguaggio, cit., p. 184. O autor chega a afirmar que ninguém fala ou pensa a mesma língua; não há, para ele, dois homens que lêem a mesma palavra e lhe dêem um idêntico significado. Em sentido estrito, segundo o autor, somente quem fala (ou escreve) sabe que coisa gostaria de dizer com suas palavras.

${ }^{141}$ Para KAUFMANN, ibidem, pp. 185-186, a carência de exatidão traz consigo o perigo que as coisas venham com sentidos velados ou falsificados, mas o preço da univocidade e exatidão de termos seria a rigidez da língua e sua redução a um número exíguo de sinais. A não univocidade da língua natural, por seu turno, garante a flexibilidade, a dinâmica, a riqueza, dentre outras qualidades. Para ele, portanto, a variação de
} 
Logo, a fim de ordenar o raciocínio até aqui exposto relativo às narrações em geral - aplicáveis, obviamente, às narrações processuais-, pode-se, em suma, afirmar que as narrativas possuem elementos epistemológicos e algumas características em comum, observáveis em todas as histórias. Dentre eles, destacou-se: a) que os relatos são necessários, além de perigosos por sua variabilidade e vagueza; b) as asserções fáticas podem ser verdadeiras, verossímeis ou falsas, sendo seu uso apropriado dependente do cenário em que inseridas; c) seus emissários e destinatários se encontram em posições epistêmicas distintas, posições essas que dependem do grau de conhecimento de cada um que lê ou escreve o enunciado formulado; d) os enunciados, muitas vezes, são apofânticos, isto é, passíveis de verificação se verdadeiros ou falsos; e) que seus significados e conseqüências, que muitas vezes dependem da verificação da verdade, são aferíveis dentro de um determinado contexto; são, pois, context-laden; e f) que as mesmas expressões são, na maioria das vezes, passíveis de interpretações variadas pelos sujeitos, não havendo univocidade de termos.

Destarte, falar de fatos, seja no processo seja na narração em geral, exige, como se viu, alguns cuidados. A visão e o tratamento dos enunciados - que apenas têm como objeto de narração acontecimentos do plano empírico - como se naturalísticos fossem faz com que se deixem de lado algumas características epistemológicas importantes da atividade narrativa. Do mesmo modo, tratar a chamada causa de pedir remota pela perspectiva processual, dando à expressão um conteúdo meramente formal, faz com que o estudioso ignore as vicissitudes dos enunciados, enfrentando o problema do fato no processo de maneira equivocada - ou ao menos incompleta.

Feitas essas observações de ordem geral, buscar-se-á no próximo item a aproximação de tais características da narração judicial, desenvolvendo os elementos identificados no âmbito específico do processo e da formação das asserções sobre os fatos da causa.

\subsection{Das narrativas judiciais}

interpretação dos termos é benéfica. Para SEARLE, o conteúdo interpretativo dos termos, além do domínio das regras que regem a linguagem como um todo, depende diretamente do conhecimento por parte do intérprete das condutas (altamente complejas) do grupo falante - condutas estas sobre as quais recaem as regras gramaticais, semânticas etc -, demonstrando que bagagens culturais diferentes induzem interpretações também distintas, Speech Acts: An Essay in the Philosophy of Language, Cambridge, 1969, tradi esp.: Actos de habla, Ensayos de filosofia del linguaje, Luis M. Valdés Villanueva (trad.), Barcelona, 1994, pp. 22 e ss.. 


\subsubsection{Da construção dos enunciados fáticos}

A questão da relatividade dos enunciados e do contexto em que inseridos - nesse item, o contexto processual - requer maiores clareamentos. Os enunciados, tal como diz a doutrina $^{142}$, não são jamais um dado em si mesmo. Ao contrário, deve-se ter em mente ao analisá-los que foram confeccionados por alguém em uma determinada situação específica, muitas vezes com um objetivo bem definido.

Desse modo, repetindo o que já fora dito alhures e que possui importância crucial para o presente trabalho, não são fatos que são trazidos aos processos e apresentados como suporte de uma demanda. São, isso sim, enunciados fáticos e jurídicos. Tais enunciados, como se pode facilmente perceber, são frutos de uma construção por parte do sujeito que o formula. Essa construção passa por diversas e complexas fases e operações, sendo o enunciado, portanto, somente o resultado final desse procedimento construtivo.

As operações referidas acima, segundo divisão feita por MiCHELE TARUFFO ${ }^{143}$, e adotada aqui em sua integralidade, podem ser agrupadas em algumas espécies.

A primeira delas é a chamada construção seletiva. Diante das inúmeras maneiras de decompor um acontecimento, da inegável complexidade da realidade e dos infinitos pontos de vista que uma determinada circunstância pode ser enfrentada, o narrador, para a construção de seus enunciados fáticos, faz uma seleção daquilo que entende como sendo relevante. Em outras palavras, frente ao que SUSAN HAACK chama de pluralidade de descrições verdadeiras da realidade ${ }^{144}$ - e, por outro lado, um sem número de possibilidade de formulações de enunciados falsos-, o indivíduo narrador faz escolhas a ponto de excluir de sua narração aquilo que não tem qualquer relevância segundo seu critério.

No âmbito das narrações processuais, dois são os critérios de seleção usados pelos agentes processuais, em especial pelo autor, pelo réu e pelo juiz. São eles: a relevância

${ }^{142}$ TARUFFO, Considerazioni, cit., p. 280.

${ }^{143}$ Ibidem, pp. 280-285.

${ }^{144}$ Manifesto of a passionate moderate. Unfashionable Essays, Chicago-Londres, 1998, p. 157; no mesmo sentido, TARUFFO, La semplice verità, cit. p. 197; na doutrina nacional, ainda que superficialmente, TESHEINER, Elementos da ação, in Revista Ajuris, Porto Alegre, nov. 1994, pp. 108 -135, visto em http://www.abdpc.org.br/abdpc/artigos/Jos\%C3\%A9\%20M\%20Tesheiner(5)\%20-formatado.pdf 
jurídica e a relevância lógica dos fatos. A primeira faz referência à qualificação do fato segundo a norma que se toma como referência para a decisão. Por se tratar de um contexto jurídico regulado por normas jurídicas, no qual o objetivo é a aplicação da lei, é o direito que informa a relevância de um determinado fato. ${ }^{145}$

As normas possuem o que a doutrina alemã chama de abstrakte Tatbestand, que equivaleria para os italianos à chamada fattispecie legal ${ }^{146}$. É justamente ela que dirá qual a perspectiva e qual o fato são importantes para a narração, além de apontar, por reverso, o que deverá ser excluído dos enunciados por não terem relevância para a aplicação dessa mesma norma. Entre os inúmeros enunciados fáticos possíveis, seleciona-se aquele que atribui ao fato a qualidade de juridicamente relevante segundo a norma que se entende aplicável (faz-se aqui referência ao que a doutrina chama de fatos jurídicos, principais, constitutivos, materiais etc).

Deixando de lado os debates sobre as dificuldades em se definir e individualizar a abstrakte Tatbestand, bem como ignorando, nesse momento, as intermináveis críticas ao pensamento silogístico do juízo de fato, assuntos que serão tratados mais adiante nesse mesmo capítulo, ressalta-se, por ora, que os narradores constroem seus enunciados levando em conta a relevância ou irrelevância jurídica de um determinado fato, relevância essa, repita-se, apurada por meio das normas que ele acredita serem aplicáveis ao caso.

Ademais, a construção seletiva pode dar-se pela perspectiva lógica de um acontecimento dentro da narrativa. Assim, um determinado fato que não está inserido na fattispecie legal adotada pelo narrador - e, portanto, não tem relevância jurídica direta pode ser, por seu turno, importante para se comprovar a veracidade de um fato tido como principal. A relevância lógica caracteriza fatos que não são juridicamente relevantes segundo a norma escolhida, mas que, entretanto, entram no processo de modo que das suas comprovações deriva a conclusão da verdade ou da falsidade de um fato dito constitutivo. O enunciado selecionado atribui relevância ao fato pela simples questão de ele constituir premissa necessária para a conclusão se um fato principal ocorreu ou não (fala-se, pois, do

${ }^{145}$ Ibidem, p. 281; ID., La prueba de los hechos, Ferrer Beltrán (trad.), Madrid, 2005, pp. 96-105 e 119-128; GAMBA, Domande senza risposta, cit., pp. 188-189; IRTI, Rilevanza giuridica (voce), in Noviss. Dig. It., vol. XV, Torino, 1957, pp. 1094-1112; MAIORCA, Fatto giuridico - fattispecie (voce), in Noviss. Dig. It., vol. VII, Torino, 1957, pp. 111-133; CATAUdELlA, Fattispecie e fatto. I. Fattispecie (voce), Enc. dir., vol. XIV, Milão, 1967, pp. 926-941; FALZEA, Fattispecie e fatto. II. Fatto giuridico (voce), Enc. dir., vol. XVI, 1967, pp. 941-950.

146 No Brasil, a doutrina usa o termo suporte fático da norma. Nesse sentido, JUNQUEIRA DE AZEVEDO, Negócio jurídico - existência, validade e eficácia, São Paulo, 2002, p. 23. 
que a doutrina costuma denominar fatos secundários, indiciários, simples, circunstanciais etc.). ${ }^{147}$

Além dessas duas espécies de fatos, há uma terceira, muitas vezes esquecida pela doutrina, que são os fatos irrelevantes. É possível que a parte (advogado) construa enunciados sobre acontecimentos que não estão contidos na fattispecie da norma e tampouco servem logicamente para comprovar a veracidade daqueles acontecimentos tidos como principais. Não apresentam, dentro da tese do narrador, qualquer relevância, quer jurídica, quer lógica ${ }^{148}$. Embora irrelevantes, se objeto de um ato enunciativo, comporá o conjunto fático processual.

Assim, pode-se dizer que o autor da narração faz uma seleção de fatos e de perspectivas destacando-se a relevância jurídica e lógica daquilo que lhe interessa, não tendo a intenção, portanto, de narrar os acontecimentos da forma mais completa e imparcial.

Uma segunda espécie de construção a que se pode fazer referência é a chamada construção semântica dos enunciados fáticos. Como entidades lingüísticas que são, dotadas de certo significado, os enunciados devem, como é óbvio, seguir as regras que regem uma determinada língua (regras gramaticais, semânticas, sintáticas etc.). Entretanto, ainda que haja um 'código' a ser seguido, o indivíduo que narra tem a liberdade para fazer escolhas quanto à forma de se expressar. Ou seja, ele pode buscar com os termos escolhidos uma maior eficácia para exprimir o significado do enunciado. Diante disso, ressalta-se, uma vez mais, que um mesmo fato pode ser narrado de infinitas maneiras, sempre a depender das escolhas feitas pelo autor do enunciado.

Entre as várias escolhas de formas lingüísticas que podem ser adotadas, uma, segundo a doutrina, chama a atenção no cenário processual. É a variação entre os termos narrativos e valorativos, ambos relativos a um fato. Como é notória, uma mesma referência empírica pode ser tomada predominantemente por uma perspectiva narrativa ou então por uma perspectiva na qual a valoração se sobressai. A significação do enunciado

${ }^{147}$ TARUFFO, Considerazioni, cit., p. 281; GAMBA, Diritto Societario, cit., pp. 404-405.

148 TARUFFO, ao analisar os fatos irrelevantes, afirma que eles podem ou não serem objetos de descrição no processo. Desse modo, tais fatos poderiam encontrar-se dentro ou fora do âmbito judicial, diferenciado-se, pois, pelo fato de que aqueles não alegados (ausentes no processo) estariam tendencialmente “'más allá del horizonte' de los hechos que el juez toma en consideración” para decisão, La prueba de los hechos, cit. p. 124 , nota 114 . 
referente a um mesmo acontecimento muda, pois, se se quer exprimir descrições ou valorações sobre o fato. ${ }^{149}$

No âmbito do processo, o impacto de uma escolha valorativa ou descritiva é imenso. Apenas a título de exemplo, destaca-se que a prova de um enunciado descritivo é perfeitamente aceitável. O mesmo não acontece quando se trata de provas sobre a valoração dada a um acontecimento. Assim, o mesmo fato, se narrado de uma forma ou de outra, pode apresentar graus variáveis de dificuldade de prova.

Como exemplo do que fora dito, pode-se pensar em dois enunciados sobre o mesmo evento, que são: a) o carro X estava em altíssima velocidade; e b) o carro X estava a uma velocidade de $60 \mathrm{~km} / \mathrm{h}$, acima, portanto, do limite permitido. A primeira asserção possui um cunho subjetivo bastante elevado, ao passo que a segunda é objetivamente definida. Em se tratando de objetos de prova, dificilmente se poderá aferir se $60 \mathrm{~km} / \mathrm{h}$ são ou não enquadráveis na expressão "altíssima velocidade". Sua significação é relativa e dependente do cenário em que formulado e daquele que interpreta ${ }^{150}$. Porém, é possível constatar se o carro estava a $60 \mathrm{~km} / \mathrm{h}$ e se essa velocidade ultrapassa o limite permitido.

Ademais, uma terceira categoria é chamada de construção categorial ou cultural do enunciado factual. Segundo TARUFFO, cada enunciado relativo à conexão entre acontecimentos implica o uso de categorias de interpretação da realidade em função das quais essas conexões vêm constituídas, alterando seu significado se porventura se alterar a categoria empregada. Assim, ainda segundo o mesmo autor, uma coisa é usar a categoria de 'causa' e outra bem diferente é usar a categoria de 'probabilidade' para afirmar que X é conseqüência de $\mathrm{Y}^{151}$

A construção categorial dos enunciados, pois, depende e varia de acordo com os pressupostos éticos, políticos, de costume, religioso etc., adotados pelo narrador, pressupostos estes que desenvolvem uma função relevante ao determinar a modalidade pelo qual um fato é descrito. Narrar que a intervenção cirúrgica feita por um médico, p.

\footnotetext{
149 TARUFFO, Considerazioni, cit., pp. 281-282; para aprofundamentos sobre enunciado de fato e enunciado de valor, PUTNAM, Razón, verdad y historia, Jose Miguel Esteban (trad.), Madrid, 1988, pp. 132.

${ }^{150} 60 \mathrm{~km} / \mathrm{h}$ podem ser uma velocidade "altíssima", por exemplo, se considerados em um condomínio fechado cheio de crianças brincando na rua. Porém, em uma auto-estrada, esses mesmos $60 \mathrm{~km} / \mathrm{h}$ podem ser extremamente lentos.

${ }^{151}$ TARUFFO, Considerazioni, cit., pp. 281-282.
} 
ex., é causa de uma infecção hospitalar é diferente de dizer que essa mesma intervenção, provavelmente, causou a infecção.

Mais uma vez se nota que um mesmo acontecimento pode ser descrito de variadas formas, tudo a depender dos pressupostos categoriais adotados pelo narrador.

Por fim, a quarta espécie de construção dos enunciados é a dita social. Muitos acontecimentos não possuem uma base empírica predominante, tratando-se daquilo que a doutrina chama de fatos institucionais. São fatos que não se determinam em função de algo materialmente perceptível como o som, a imagem, o calor etc., mas sim do contexto social que os envolvem e os definem ${ }^{152}$. Muitos são os exemplos referentes a estes fatos e não caberia aqui uma listagem exaustiva. Contudo, algumas referências parecem ser úteis para esclarecimento do conceito.

O dinheiro só é dinheiro - e não um pedaço de papel colorido - por uma questão institucional. No exemplo acima usado, as transações realizadas na bolsa de valores de Nova York são consideradas existentes no mundo financeiro. Uma relação sexual com pessoa terceira que não o cônjuge só é adultério dentro de um cenário legal e religioso (em uma sociedade em que essa relação é comum e aceita, sem que se receba qualquer reprovação social ou legal, não há a produção dos mesmos efeitos caso considerado em uma sociedade permeada pela religiosidade, inexistindo assim a roupagem social chamada 'adultério'). Trazendo para um cenário mais palpável, uma declaração de vontade só se configura um negócio jurídico se houver ali o que a doutrina chama de circunstâncias negociais, ou seja, um cenário institucional apto a reconhecê-lo como tal. Um homem que diz a seu mordomo: "passe minha roupa", embora esteja declarando sua vontade livremente, não está celebrando qualquer negócio jurídico que seja. Um caçador que atira em uma presa com o pensamento de que a lei lhe atribui a propriedade da caça não está, outrossim, concluindo um negócio jurídico. Em outras palavras, mesmo agindo ansiando os efeitos legais da caça, faltam as condições negociais ao caçador para que o ato seja tido como negócio jurídico. ${ }^{153}$

\footnotetext{
${ }^{152}$ Ibidem, p. 283. Sobre fatos brutos e fatos institucionais na linguagem, ver SEARLE, Actos de habla, cit., pp. 58 e ss.

153 Nesse sentido, para maiores aprofundamentos e críticas quanto às teorias objetiva e voluntarista do negócio jurídico, ver JUNQUEIRA DE AZEVEDO, Negócio jurídico, cit., pp. 1-22.
} 
Não obstante a larga base empírica dos últimos exemplos, nota-se que há algo a mais para que ganhem a dimensão de relevância social e jurídica. Esse algo é justamente o contexto social que envolve e define certo fato.

Desse modo, percebe-se que a construção de um enunciado fático pode variar quanto ao grau empírico ou institucional. Pode-se atribuir maior ou menor 'empiricidade' ou 'institucionalidade' a depender da forma como se narra. Ademais, a construção do enunciado depende, igualmente, da 'carga' social do narrador. $\mathrm{O}$ autor das asserções sobre um acontecimento constrói sua narrativa baseado na sua visão institucional do fato (muçulmanos e católicos enfrentam, por exemplo, de maneiras diversas a monogamia).

Em apertadíssima síntese, buscou-se demonstrar nesse item do trabalho, ainda que brevemente, que cada enunciado sobre um determinado fato é fruto de um complexo processo de construção realizado pelo narrador. Sobre um mesmo acontecimento podem ser formulados infinitos enunciados verdadeiros, bem como um sem número de enunciados falsos, tudo a depender do processo construtivo (seletivo, semântico, categorial e social) daquele que está encarregado de narrar o ocorrido.

Destarte, parece equivocado, se ignorados esses elementos epistemológicos até aqui expostos, falar em 'fatos do processo' (ou causa de pedir remota, como querem alguns). O fato de não considerar as vicissitudes do procedimento de 'entrada' dos fatos no âmbito processual implica, em regra, em uma simplificação inaceitável, capaz de trazer uma visão distorcida e embaraçada dos fatos que estão à base do direito em jogo. Como se buscou demonstrar, tratar a causa de pedir relativa aos fatos como um fato em si e não como um enunciado referente a um acontecimento ignora as inúmeras variações das construções da narrativa.

A causa petendi, como dito anteriormente, é tomada por uma perspectiva processual e simplista. É encarada pela doutrina - atentando-se para as variedades do conceito já expostas - como os fatos limitados pelas alegações (fáticas e jurídicas) do autor feitas na petição inicial, sem que se façam maiores aprofundamentos sobre a questão. Há, ao assim interpretar a causa de pedir, um esquecimento quanto aos aspectos da 'passagem' dos acontecimentos do plano fenomênico para o âmbito escrito do processo, olvidando-se, pois, de elementos fundamentais desse procedimento de construção das asserções. Apenas abrindo um parêntese, crê-se, até mesmo, que essa maneira simplória de tratar o tema é que 
faz com que cada autor adote um conceito distinto de causa de pedir e, a partir daí, conclua suas análises antagonicamente aos estudiosos precedentes.

Desse modo, pode-se pensar na seguinte situação: um mesmo acontecimento, narrado por diferentes advogados ${ }^{154}$ - e, portanto, com enunciados construídos diversamente - poderia originar causas de pedir distintas, o que é inaceitável ao se pensar que a insatisfação dos indivíduos e a necessidade de tutela de direitos são as mesmas.

Assim sendo, crê-se que o tema deve ser tomado pela perspectiva ora apresentada. Ao se falar em 'fatos no processo', deve-se levar em conta todas as nuances acima descritas, sob pena de se incorrer em uma simplificação que causa mais problemas que soluções.

Dito isso e destacados alguns pontos que se tinham por fundamentais, pode-se agora desenvolver a análise proposta sobre os 'fatos' no âmbito judicial. É o que se passa a fazer no item subseqüente do trabalho.

\subsubsection{Da incompletude e parcialidade dos fatos trazidos com o ato introdutório}

O presente tópico do estudo busca analisar os fatos trazidos com a inicial. Antes disso, porém, alguns elementos já expostos devem ser retomados. Ainda que soe repetitivo o discurso, crê-se que o destaque desses pontos seja fundamental para o desenvolvimento do raciocínio que se pretende traçar.

Como dito alhures, não são fatos que são apresentados no processo como fundamentos de uma pretensão. A parte que vem a juízo em busca de uma tutela jurisdicional de um pretenso direito seu formula, isso sim, em seu ato introdutório, enunciados sobre os fatos. Esses enunciados, por motivos que já foram deduzidos e que

\footnotetext{
${ }^{154}$ Diante do que foi até exposto, cabe sobre o ponto algumas observações. O advogado, responsável por formular os enunciados de fato, está, ao receber o cliente em seu escritório, na posição de um leitor não informado (LNI) sobre os acontecimentos. Ele, em regra, não presenciou o que realmente aconteceu para a formação da insatisfação de seu potencial cliente. Logo, o 'material' por ele recebido para iniciar seu trabalho é também uma narração, fruto de escolhas feitas pelo indivíduo que o procura, passível de todas as observações críticas feitas até então. A partir disso, o operador do direito formula, por meio de todo o procedimento construtivo exposto, as asserções que serão apresentadas em juízo, isto é, que comporão a demanda. Em relação à variabilidade das narrações e a atribuição de importância ao fato descrito, destacando o mesmo fator de diversidade aqui apontado, ver TARUFFO, La prueba de los hechos, cit. p. 124.
} 
continuarão a ser desenvolvidos ao longo deste estudo, jamais representam a realidade em sua integralidade.

Segundo uma análise conduzida por um perfil epistemológico, um fato não é e nunca foi uma entidade simples e homogênea que pode ser definido exaustivamente com um enunciado elementar do tipo ' $\mathrm{x}$ '. Ao contrário disso, os acontecimentos da vida são compostos por uma série de circunstâncias, tais como tempo, espaço, temperatura, pressão, cor, som, comportamento dos envolvidos, que em conjunto formam o fato ${ }^{155}$. Dessa maneira, um fato comporta inúmeras descrições possíveis, tomado pelos mais variados ângulos de observação, sendo destacados pelo narrador os aspectos que mais chamaram sua atenção (ou que mais coadunam com seus interesses narrativos).

Analisando esses meandros da matéria, a doutrina que encara os fatos pela perspectiva epistemológica aponta para a possibilidade de um determinado fato ser decomposto em duas direções: uma qualitativa e outra quantitativa. ${ }^{156}$

A decomposição qualitativa é aquela na qual se individualizam aspectos distintos do mesmo fato. Descreve-se, pois, inúmeros 'pedaços' do acontecimento em questão. Em um acidente, por exemplo, pode-se descrever a velocidade do automóvel, sua cor, o número de sua placa, se o condutor estava embriagado etc. Tal decomposição é potencializada caso se inclua aí o fenômeno conhecido na ciência como roto-translação, conceito que indica uma série de operações mediante as quais o mesmo objeto é observado por diversos pontos de vista. ${ }^{157}$

A decomposição quantitativa, por seu turno, é aquela na qual um acontecimento é analisado em seus detalhes, em sua precisão. Utilizando-se o mesmo exemplo do acidente, o fato pode ser decomposto descrevendo-se o automóvel pelo funcionamento do seu motor, seguido de uma descrição de cada uma de suas peças, especificando-se a narrativa até se atingir níveis moleculares. ${ }^{158}$

A pertinência quanto a uma maior ou menor especificação depende do cenário no qual está inserida a descrição do fato.

\footnotetext{
${ }^{155}$ Tais observações são de GAMBA, Domande senza risposta, cit. p. 163.

156 TARUFFO, La prueba de los hechos, cit., pp. 93 e 95.

${ }^{157}$ Idem, ibidem; ademais, para uma análise feita em âmbito distinto do judicial, ver: TORALDO DI FRANCIA, Le cose e i loro nomi, Bari, 1986, pp. 27 e ss.

${ }^{158}$ O exemplo é de TARUFFO, La prueba de los hechos, p. 94.
} 
Como se pode notar, a combinação de ambas as possíveis decomposições, que não possui limites teóricos, pode facilmente portar a idéia de que não há nenhuma descrição adequada e exauriente de um fato. Ao contrário disso, infinitas são as possíveis narrações sensatas e verdadeiras em relação a um determinado acontecimento. ${ }^{159}$

Os fatos, portanto, são entidades complexas que podem ser descritas por inúmeras formas, todas elas verdadeiras e coerentes. Do mesmo modo, podem-se formular infinitas descrições falsas sobre o mesmo acontecimento. O fato é, pois, pela perspectiva aqui adotada, algo muito distinto daquele fenômeno reduzido e simplificado invocado pela doutrina processual, de caráter preciso, definido, nítido e integral. ${ }^{160}$

Desse modo, uma narração, pela sua própria natureza, por uma característica que lhe é intrínseca, não é capaz de reproduzir, por mais fidedigna que seja, qualquer acontecimento de forma exauriente e completa.

Somando-se a isso, deve-se destacar que, no âmbito de um processo, não é o próprio envolvido que busca retratar os acontecimentos. $\mathrm{O}$ indivíduo que possui uma insatisfação narra sua situação a um profissional, que será responsável por confeccionar a peça escrita que dará início ao processo (excetuando-se raras exceções legais previstas pelo sistema, tal como aquela prevista pela Lei ${ }^{\circ}$ 9.099/95).

Nesse sentido, as narrativas processuais serão geralmente formuladas por advogados, e não pela própria parte. Em outros termos, as asserções contidas na inicial e que fundamentarão a demanda serão obra de um indivíduo que não presenciou os acontecimentos, mas teve conhecimento deles tão só por meio das narrações de um dos envolvidos. ${ }^{161}$

Ademais, importante notar que os advogados, ao escreverem a peça introdutória, o fazem visando ao convencimento do juiz. Desse modo, não têm como objetivo precípuo o esclarecimento da verdade e a correta aplicação da lei, tampouco buscam a justa decisão. Tracejam as suas 'histórias' processuais, como se pode imaginar, com tons de argumentos

\footnotetext{
${ }^{159}$ Fenômeno já tratado anteriormente com indicação bibliográfica na nota 37.

${ }^{160}$ Essa mesma crítica é feita por TARUFFO, que afirma que "la idea de sentido común según la cual de todo fato existe una descripción objetiva y apropiada parece, pues, evidentemente inaceptabile, no sobre la base de aproximaciones subjetivistas, sino porque los niveles de análisis de la misma situación pueden ser muy distintos (in teoría: ilimitadamente)", La prueba de los hechos, cit., p. 94; no mesmo sentido, GAMBA, Domande senza risposta, cit., p. 164.

${ }^{161}$ Os impactos disso no processo foram expostos, com exemplos, na nota 34 desse capítulo.
} 
racionais, utilizam técnicas para destacar informações e pontos relevantes à tese por eles sustentada, ressaltam apenas os fatos que julgam importantes. As narrações feitas pelos advogados, portanto, tendem a ser incompletas e parciais, tudo como conseqüência de uma manipulação consciente dos fatos orientada sempre a vencer o caso. ${ }^{162}$

Não cabem nessa senda maiores aprofundamentos quanto ao debate que versa sobre o dever dos advogados de dizer a verdade no processo e os limites da atuação e da ética profissional do operador do direito ${ }^{163}$. Deixando de lado as inúmeras divergências que o argumento apresenta, certo é que as previsões legais trazidas pelos arts. 14, I, e 17, II, ambos do CPC de 1973, que dispõem que os advogados estão obrigados a expor os fatos em juízo conforme a verdade e a eles é vedado alterar a verdade dos fatos, respectivamente, não significam que os enunciados devem ser verdadeiros. Caso contrário, todos aqueles que não conseguissem comprovar o fato alegado - ou que tivessem uma prova contrária às suas alegações - deveriam ser condenados por litigância de má-fé, o que não se pode aceitar.

Ademais, tampouco tais dispositivos legais obrigam o advogado a expor toda a verdade. Em outras palavras, parece indefensável qualquer posicionamento no sentido de que o código, por meio dos artigos apontados, teria instituído um dever aos patronos de trazerem a integralidade dos fatos conhecidos ao processo. Primeiro pela simples razão de que a exigência prática desse dever não seria de fácil alcance, já que dificilmente se pode aferir qual a extensão e a profundidade do conhecimento do patrono ao se formular a demanda. Ademais, porque um raciocínio assim defende que a parte (rectius: seu advogado) esteja obrigada a trazer em meio a sua tese todos os acontecimentos e provas, inclusive aqueles que são contrários à sua própria pretensão.

Diante dessas afirmações, confrontadas com algumas alegações anteriores de que no cenário processual a verdade dos enunciados é fundamental para que haja o efeito jurídico invocado, o leitor pode ficar com uma sensação de contra senso, isto é, de incoerência entre o que foi dito. Explica-se.

\footnotetext{
${ }^{162}$ Nesse mesmo sentido, com referência aos sistemas inglês e alemão, TARUFFO, Narrativas, cit. pp. 243244, para quem 'las narraciones de los abogados tienden a incluir una manipulación de los hechos, orientada a ganar el caso'. Para uma análise quanto às mentiras trazidas pelos advogados, ver COLOMA CORREA, Vamos a contar mentiras tralará..., O de límite a los dichos de los abogados, in Rev. de Derecho, Universidad Austral de Chile, XIX, n. 2, 2006, pp. 27-52.

${ }^{163}$ Sobre o tema, com referências bibliográficas, ver CIPRIANI, L'avvocato e la verità, in Yarshell e Moraes (coord.), Estudos em homenagem à professora Ada Paellegrini Grinover, São Paulo, 2005, pp. 821-826.
} 
É de se notar que as alegações formuladas pelos advogados, explícita ou implicitamente, pretendem ser verdadeiras. Não haveria sentido algum se um advogado invocasse um fato material e, na seqüência, afirmasse que ele é falso. Ou, por outro lado, fizesse uma afirmação visivelmente falsa, sem qualquer pretensão de ser verdadeira, tal como "no fundo do mato-virgem nasceu Macunaíma, herói de nossa gente".

Assim sendo, a pretensão de veracidade, como demonstrado, é típica das narrações dos advogados ${ }^{164}$. Isso, entretanto, não significa que elas são verdadeiras. Afirmar que algo pretende ser verdadeiro não equivale a dizer que é efetivamente verdade o que se afirmou. As histórias dos advogados acerca de um determinado acontecimento nada mais são que histórias hipotéticas relativas ao fato e passíveis, portanto, de averiguação (são, como se disse, apofânticas). Se os enunciados por eles formulados são verdadeiros ou falsos é matéria para um momento posterior à confecção da narração. Somente se poderá constatar a veracidade ou falsidade das narrativas durante o curso do processo e no momento da decisão final. ${ }^{165}$

Em termos técnicos, tomando como referência a teoria dos atos da fala, as narrações dos advogados pertencem aos chamados atos ilocutórios. Esta categoria de atos é caracterizada por enunciados que visam à formulação de uma proposição verdadeira, descrevendo um fato com uma direção de ajuste palavra-mundo ${ }^{166}$.

Logo, diante dessas características, há nas histórias processuais somente uma potencial veracidade. Como conseqüência, por outra perspectiva, há, outrossim, uma potencial falsidade do que fora narrado e posto à base da petição inicial.

No âmbito do processo judicial, outro elemento funcional ilocutório pode ser destacado. Como já referido anteriormente, os advogados buscam vencer a demanda por

\footnotetext{
${ }^{164}$ Assim, ver TARUFFO, La semplice verità, cit., pp. 43 e, especificamente, p. 47: "quando un avvocato allega dei fatti, implicitamente o esplicitamente afferma che questi fatti sono veri". Em momento mais específico, afirma o mesmo autor: "En realidad, se trata sólo de conjecturas acerca de la situació: los hechos concretos son únicamente alegados, es decir, 'afirmados' como verdaderos, pero no han sido todavía 'determinados' como verdaderos. Las operaciones recién descritas son útiles precisamente para estabelecer qué hechos deben ser probados em juicio para que la controversia pueda ser decidida según aquella norma específica", La prueba de los hechos, cit. p. 122.

165 TARUFFO, Narrativas, cit. p. 246; GAMBA, Domande senza risposta, cit. pp. 161-162.

${ }^{166}$ Idem, Ibidem. Para maiores aprofundamentos sobre os atos ilocutórios, com referência a inúmeras teorias sobre o conceito de ato ilocutório, ver CLAUDIA CAFFI, Illocuzione, metacomunicazione, coinvolgimento, cit., pp. 11-18. Com interessante ponderação sobre atos ilocutórios e a digressão no discurso escrito e oral, ver OLIVEIRA ANDRADE, A digressão como estratégia discursiva na produção de textos orais e escritos, in ABRALIN, 14, 1993, pp. 425-434.
} 
meio do convencimento do julgador. Desse modo, as histórias são construídas com o fim de persuadir o juiz. Por essa perspectiva, destaca-se outra finalidade ilocutória do ato, qual seja, a característica diretiva da asserção, dirigida a sustentar uma tese e um pedido que poderá ser concedido ou negado. ${ }^{167}$

Outro fator importante que aqui se pode destacar, ainda relativo às enunciações fáticas feita pelos advogados, é aquele relativo ao ônus probatório. Como é sabido, o ônus de provar a veracidade de um determinado enunciado é daquele que faz a afirmação, salvo se houver alguma disposição legal em contrário, algumas presunções legais oriundas da experiência ou, ainda, se o tribunal estabelecer uma distribuição dos ônus diversa daquela prevista em lei. Desse modo, ao formular uma narração judicial, o advogado, em tese, leva em conta quais fatos são passíveis de prova, as dificuldades em realizar essas provas, bem como a viabilidade da demonstração do acontecimento. Logo, se se conclui previamente que aquele fato é fundamental para a sustentação da tese escolhida, mas que sua comprovação é impossível, muito provavelmente a tese será alterada e o fato 'escondido', ou seja, deixado de lado. ${ }^{168}$

Os objetivos dos sujeitos envolvidos e seus comportamentos remetem, ainda, a outro conceito de fundamental importância na confecção dos enunciados fáticos, conceito este que pertence às ciências sociais, mais especificamente à sociologia. NORBERT ELIAS, em estudo sobre o comportamento dos indivíduos ante a consciência da realidade, fala em dois conceitos: o de envolvimento e o de destaque. ${ }^{169}$

Destaque se refere à conduta daqueles que não possuem interesse específico ao observar a realidade. Como conseqüência, há uma tendência em serem objetivos nas suas reconstruções dos acontecimentos. Envolvimento, por outro lado, faz referência ao comportamento de pessoas que possuem determinado interesse nos acontecimentos, isto é, estão envolvidos com a realidade que observam. O reflexo desse envolvimento é a premente tendência de uma reconstrução parcial dos fenômenos condicionada àquele interesse. Tais conceitos são perfeitamente transmutáveis ao âmbito processual, no qual as

\footnotetext{
${ }^{167}$ TARUFFO, La semplice verità, cit. p. 46.

${ }^{168}$ Para interessantes observações quanto à relação entre ônus da prova - comportamento das partes, ver YARSHELl, Antecipação da prova sem o requisito da urgência e direito autônomo à prova, São Paulo, 2009, p. 65 e ss.. No mesmo sentido das afirmações do texto, TARUFFO, Narrativas, cit., p. 247.

${ }^{169}$ Coinvolgimento e distacco. Saggi di sociologia della conoscenza, Bologna, 1988, pp. 89-143.
} 
partes, autor e réu, são 'coinvolte', ao passo que juízes, testemunhas, peritos etc. são, em tese, destacados. ${ }^{170}$

O autor, como se pode ver, não expõe por meio de seu ato introdutório todos os fatos, visando a uma decisão justa e fundada sobre a mais fiel reprodução da realidade. Ao contrário, busca, isso sim, uma decisão que lhe favoreça, que lhe conceda o bem da vida em disputa. Desse modo, posiciona os fatos de maneira a convencer o juiz da sua versão e de sua tese, fazendo um recorte direcionado dos acontecimentos observáveis no plano fenomênico.

Diante de tudo o que fora exposto até o momento, uma conclusão parece evidente: as narrativas trazidas com a petição inicial, responsáveis por introduzir a demanda em juízo descrevendo a insatisfação do autor, são subjetivas, incompletas e parciais, além de potencialmente falsas, quer pela natureza intrínseca ao método descritivo, que jamais são capazes de reproduzir em sua integralidade os acontecimentos do mundo, quer pela posição epistemológica e pelos objetivos ilocutórios das partes envolvidas, que possuem posições sociológicas e epistêmicas de envolvimento. ${ }^{171}$

Assim, o material sobre o qual deverá incidir a decisão (isto é, a crise exposta em juízo e para a qual se pede uma solução) não vem, diferentemente do que defende a doutrina majoritária, pronto e identificado no ato introdutório. Os fatos, componentes da chamada causa de pedir remota, não estão descritos em sua integralidade e de maneira imparcial, com delimitação clara e completa, o que impossibilita dizer, já no primeiro momento, quais seriam as reais dimensões da crise ali exposta.

Como se verá mais adiante, a clarificação das dimensões exatas do conflito é algo dinâmico, algo que se desenvolve durante todo o processo. Bloquear os fatos da demanda

170 Idem, p. 19; GAMBA, Domande senza risposta, cit., p. 154; ID., Diritto societario, cit. pp. 408-409; TARUFFO, Elementi per un'analisi del giudizio di fatto, in Sui Confini, Bologna, 2002, p. 240 e ss.. Para uma análise dos efeitos do envolvimento e do destaque na modalidade de expressão e sobre a lingüística, CAFFI, Illocuzione, metacomunicazione, coinvolgimento, cit., pp. 67 e ss.

${ }^{171}$ GAMBA, Domande senza risposta, cit., p. 164; TARUFFO, Elementi per un'analisi, cit., p. 241.; TWINING, Rethinking Evidence, cit., pp. 295. Nota-se, porém, que a doutrina clássica, ao tratar do ato introdutório, acaba por não levar em consideração essas características, tratando o fato como algo 'bruto' e determinado, como o evento em si capaz de ser exaurido por meio do ato narrativo. Nesse sentido, DINAMARCO assim afirma: "Daí a inépcia de uma petição inicial à qual falte, entre outros elementos essenciais, a causa de pedir deduzida de modo claro e com inteireza em relação aos fatos relevantes para a constituição de direito", Ônus de afirmar e causa petendi - Os documentos indispensáveis à propositura da demanda - Ônus de afirmar e ônus de impugnação específica (CPC, art. 302) - Pedido determinado e sentença líquida - Confissões de dívida como declarações de vontade constitutivas - Honorários advocatícios, in Revista Forense, Rio de Janeiro, jan/mar 1998, p. 234. 
(rectius: formulações sobre os fatos feitas pelas partes) no ato introdutório, com pequenas margens para variações, tudo por um equívoco de perspectiva, parece, ao menos diante do que até aqui se expôs, um obstáculo para a correta solução da crise.

Antes de adentrar no tema da relação entre demanda/cenário fático do conflito /sentença-solução justa, far-se-á algumas outras considerações sobre os enunciados de fatos no processo, destacando-se os aspectos de sua relevância e complexidade, ressaltando-se, no mesmo sentido do que fora até aqui exposto, a parcialidade e incompletude das narrativas processuais.

\subsubsection{O fato e sua complexidade}

Retomando o que já fora dito inúmeras vezes anteriormente, a demanda introduzida pelo autor por meio da petição inicial se sustenta não sobre fatos - acontecimentos naturalísticos e simplificados -, mas sim se apóia em enunciados sobre os fatos, isto é, sobre hipóteses formuladas pelo autor relativas aos acontecimentos da vida, enunciados que possuem uma série de peculiaridades e especificidades.

Tais enunciados são frutos de um processo de construção realizado pelo indivíduo insatisfeito (ou melhor, por seu advogado), apresentando, deste modo, um caráter incompleto e parcial da realidade ${ }^{172}$, além de uma potencial falsidade das alegações. Não cabe neste momento do trabalho desenvolver maiores considerações sobre o impacto dessas características do 'conjunto fático' inicialmente proposto sobre a decisão final do juiz. Tal tema será objeto de atenção mais adiante. É pertinente nesse momento, todavia, traçar algumas observações sobre a complexidade dos fatos e sua relação com o âmbito processual.

Normalmente, ao tratar dos fatos no processo, parte da doutrina e da jurisprudência faz uma simplificação inaceitável, geradora de inúmeros problemas, tratando-os como algo ‘bruto', como um acontecimento empírico ${ }^{173}$. Quando muito, generalizam e tratam o termo

\footnotetext{
${ }^{172}$ Os motivos da incompletude e parcialidade foram objetos dos itens anteriores.

${ }^{173}$ Como foi dito, não há propriamente um questionamento por parte da doutrina processual tida aqui por 'clássica' quanto ao que seriam os fatos do processo, qual a sua natureza etc. Sem o enfrentamento do que são os fatos no processo, partem diretamente às classificações dos mesmos. Os 'fatos', pois, são tratados como algo definido, com delimitação clara e simples, o que gera as dificuldades que se tem buscado apontar.
} 
‘fato' fazendo referência a acontecimentos cuja estrutura é extremamente simples. Em outros termos, toma-se como modelo de fato um evento precisamente situado entre coordenadas espaço-temporais muito bem determinadas.

É bem verdade que se pode pensar em estruturas factuais simples que seguem o seguinte esquema: fato X, ocorrido no momento M e local L. Alguns fatos, como se nota, são passíveis de uma descrição simplificada capaz de identificar e individualizar o acontecimento que se toma como objeto da narração. No contexto processual, são facilmente conformáveis com a norma tida como aplicável, ou seja, facilmente individualizáveis no substrato fático normativo, bem como apresentam pequenas dificuldade como objetos de narração processual, já que apenas alguns poucos enunciados, embora não capazes de reconstituir o acontecimento em sua integralidade - como dito alhures -, são suficientes para destacar os aspectos importantes do evento que identificam a crise para a qual se pede a tutela.

Desse modo, pode-se trazer como exemplos, dentre tantos outros possíveis, um acidente de trânsito, um descumprimento de uma cláusula contratual, um inadimplemento de um contrato de compra e venda etc. Ainda assim, e levando em consideração que um fato, em suas possíveis descrições, pode ser decomposto em duas direções - qualitativa e quantitativa -, pode-se pensar em uma situação processual na qual um acontecimento inicialmente tido como simples pelo narrador (ou melhor, pelo advogado do autor ou do réu) tenha que ter sua descrição alterada devido a um contexto posterior.

Para deixar mais claro o que aqui se busca desenvolver, tomar-se-á como objeto de análise o caso do acidente de trânsito, podendo-se, todavia, transpor o raciocínio aos demais exemplos de fatos simples acima trazidos.

Na situação proposta, pode-se pensar em um indivíduo que pleiteie indenização por ter sido atropelado por um ônibus. Segundo a estrutura da obrigação por ato ilícito, sua descrição pode ser reduzida ao esquema fato $\mathrm{X}$, local $\mathrm{L}$ e momento $\mathrm{M}$, por culpa/imprudência/imperícia do condutor/empresa. A descrição inicial pode ser feita com maiores ou menores especificidades, tudo a depender da decomposição redacional feita pelo interessado. O autor (rectius: seu advogado) formula seus enunciados sobre o evento de maneira simplificada, crendo serem suficientes as bases espaciais e temporais unitárias expostas na inicial. Contudo, a depender do desenrolar do processo, pode ser que o narrador tenha que decompor o acidente em vários outros acontecimentos menores, como, 
p. ex., a falha mecânica do freio do veículo, originada por uma ausência de revisão por parte da empresa proprietária do ônibus, agravada pela velocidade com que o veículo se movia etc..

Logo, a descrição que a priori apresentava-se como simples teve que ser alterada, decompondo-se o evento inicialmente tomado como unitário, tanto qualitativa quanto quantitativamente, em diversos outros 'mini-fatos'. 174

Ademais, a simplicidade do esquema descrito nem sempre se faz presente. São freqüentes os casos nos quais o fato não é específico, claro, bem delimitado quanto às coordenadas de tempo e de espaço. Esses fatos são denominados 'complexos' 175 e apresentam uma série de dificuldades no que tange ao âmbito processual. Antes de aprofundar qualquer consideração sobre os problemas do tema, alguns pontos sobre a 'complexidade' deverão ser relevados a título de premissa.

Segundo TARUFFO, duas são as acepções que se podem atribuir à expressão "fatos complexos".

A primeira delas é aquela relativa ao fato composto por diversas e distintas 'partes'. Um contrato, por exemplo, pode apresentar várias cláusulas importantes para um determinado caso. Da mesma forma, um acidente, se encarado pela dinâmica pela qual se produziu, pode ser tido como um "fato complexo", tal como referido acima. Muitos outros exemplos poderiam ser dados, mas os dois acima são suficientes para a compreensão desse sentido do termo 'fato complexo'. ${ }^{176}$

A segunda dimensão de complexidade é relacionada à duração no tempo. A posse, por exemplo, só será elemento de aquisição originária de propriedade de imóvel, para os fins do art. 1.238 do Código Civil, se, e somente se, for prolongada sem interrupção, nem

\footnotetext{
${ }^{174}$ Não bastasse a hipótese aventada, o fato simples ainda pode apresentar complexidades quando tratar-se de um fato não material, mas psíquico. Não se trata aqui das situações nas quais o fato se equipara para fins legais e processuais à sua externalização, como, por exemplo, a vontade e a declaração de vontade em um negócio jurídico. Nesse caso, basta o autor invocar o acontecimento material (assinatura do instrumento) e o fato psíquico estará contemplado. Entretanto, como aponta a doutrina, há fatos psíquicos em que a sua enunciação simples não basta: necessário será narrar, outrossim, fatos indiretos dos quais se possa inferir o conteúdo da esfera psíquica do sujeito, tornando o evento que era narrável inicialmente por uma estrutura simples em algo mais complexo. Para aprofundamentos sobre fatos psíquicos, ver TARUFFO, La prueba de los hechos, cit. pp. 159 e ss.

${ }^{175}$ Sobre a distinção entre fato simples e fato complexo, ver MAIORCA, cit., p. 125.

176 TARUFFO, em La prueba de los hechos, cit., p. 144, cita ainda uma negociação em que as partes possuem posições divergentes, além da redação de um balancete, dentre outros.
} 
oposição, por quinze anos. Um direito só estará prescrito após, dentre outros requisitos, a passagem do tempo. ${ }^{177}$

Como se nota, as duas acepções não são excludentes entre si. Ao contrário, muitos fatos são complexos por apresentarem ambos os fatores conjuntamente. Aliás, quanto mais 'pedaços' compuserem um fato e quanto mais duradouro ele for, mais complexo ele será. Há aí uma relação direta de proporcionalidade. É fácil pensar em um acontecimento que, simultaneamente, seja composto por vários 'fatos simples' e que se prolongue no tempo, tal como a execução de um negócio jurídico com boa-fé, a educação de filhos, a administração de uma empresa etc. Aliás, freqüentemente se nota comportamentos ou atividades da vida quotidiana que são desenvolvidas ao longo de um lapso temporal razoável e, justamente por isso, são compostos por inúmeros 'pedaços' que podem ser destacados em uma narração.

Feitas essas observações, pode-se perceber que um fato qualificado como complexo é dificilmente - se não impossível - identificável e individualizável com precisão analítica em sua inteireza. Retomando o que fora dito alhures, a atividade descritiva, independentemente se tiver como objeto um fato simples ou complexo, jamais será exauriente, completa, capaz de cobrir todos os meandros do acontecimento. Disse-se, outrossim, que se pode formular várias enunciações distintas entre si, todas, porém, verdadeiras. Quando se trata de um fato complexo, entretanto, por razões óbvias, é necessário que o narrador realize uma atividade enunciativa muito mais completa para que o evento possa ser identificável com clareza razoável.

A dificuldade apontada tem reflexos diretos na formação da petição inicial, assim como influencia as narrativas defensivas do réu e, mais adiante, a narração feita pelo juiz em sua sentença como fundamentação da decisão. No que diz respeito às partes e suas manifestações iniciais - ato introdutório e contestação, além, claro, da reconvenção -, surgem questionamentos como: é necessário que se narre todos os 'pedaços' componentes do fato complexo? Quais partes desses fatos devem ser objeto de narração? Quais são os momentos, se considerados fatos que se protraem no tempo, mais importantes? Devem-se buscar narrações que abranjam todas as 'fatias' de acontecimento durante todo o período? Enfim, questões como essas - além de várias outras imagináveis - aparecem sempre que uma narração for confeccionada, inclusive se referente a fatos simples. Contudo, como é

${ }^{177}$ Ibidem, pp. 144-145. 
intuitivo, ganham relevo em se tratando de um fato complexo que deva ser enunciado e posto à base de uma petição introdutória. Em um processo cheio de preclusões, deixar de narrar pedaços e momentos importantes de um fato complexo pode ser crucial para que, ao final, advenha uma derrota.

Dentro de um contexto processual, como já afirmado, são as normas que determinam quais fatos devem ser apresentados e quais poderão ser deixados de lado. Ocorre, todavia, que a complexidade apontada, em ambas as perspectivas, dificultam a individualização daquilo que compõe o suporte fático normativo. Em outras palavras, a complexidade de um fato, por sua extensão e profundidade, dificulta o procedimento interpretativo do operador do direito. No que tange às partes, a dificuldade está em saber quais aspectos do fato complexo deverão ser destacados para que a norma escolhida possa ser aplicada. Quanto ao juiz, a adversidade está em identificar quais os aspectos é que deverão ser provados para que haja uma correta solução do caso submetido à sua análise.

Maiores aprofundamentos quanto à identificação da fattispecie e os problemas que o tema apresenta deverão ser trazidos no tópico seguinte sobre a relevância dos fatos no processo. Para o momento, todavia, é possível afirmar que, diante das dificuldades de identificação com precisão analítica dos fatos complexos, a norma e seu suporte fático ajudam a identificar alguns de seus aspectos que seriam, em tese, relevantes e destacáveis e, como tais, devem ser objeto de atenção pelos narradores envolvidos e pelo juiz. ${ }^{178}$

Assim, toma-se como exemplo a chamada convivência intolerável entre cônjuges. Embora o Código Civil de 2002 tenha abandonado o princípio da culpa como requisito para obtenção do divórcio, o exemplo é bastante usado pela doutrina clássica e, no que tange à modificação da demanda, é fonte de inúmeras divergências, além de ser bastante elucidativo quanto ao que aqui se quer fazer claro.

É intuitivo pensar que não cabia ao autor da ação de divórcio narrar todos os comportamentos de seu cônjuge que, segundo ele, tornariam sua convivência intolerável. Para que pudesse obter a tutela constitutiva negativa pleiteada, bastava que apenas alguns eventos idôneos a demonstrar a intolerabilidade fossem descritos e provados ${ }^{179}$. Importante

\footnotetext{
${ }^{178}$ Ibidem, p. 145.

179 A parte as já citadas limitações intrínsecas do ato enunciativo quanto à completude dos fatos, resta evidente que uma descrição exauriente de uma convivência intolerável exigiria um trabalho sobre humano, de resto impossível, principalmente se se tratar de uma narração em prosa, como ocorre no processo.
} 
notar, portanto, que o fato "convivência intolerável" "180, de caráter complexo, não obstante não 'entrasse' por completo no processo, mas tivesse tão somente alguns aspectos destacados no âmbito da petição inicial, estava por inteiro contido na base de sustentação das demandas formuladas. Em outras palavras, a insatisfação de um dos cônjuges, por razões óbvias, não advinha apenas dos eventos ou comportamentos enunciados por ele no bojo do processo, mas de todas as condutas e fatos que, ao longo de um lapso temporal considerável, corroeram a base do matrimônio, de resto, impossíveis, como já afirmado, de serem narrados à exaustão. ${ }^{181}$

Como se pode concluir com facilidade, se o autor narrasse dois ou três acontecimentos como fundamento de sua pretensão constitutiva, já estaria cumprida a exigência legal do código de processo. Entretanto, para clarear a ideia, é possível pensar que os enunciados de fatos isolados, descolados do substrato fático existente, potencialmente poderiam não ser suficientes para, sozinhos, destruírem uma convivência harmônica. Somente o conjunto de condutas e comportamentos, dentre eles aqueles deixados de fora do processo, é que tornariam a vivência insustentável. ${ }^{182}$

Diante dessas observações, cabe nesse momento abrir um parêntese para analisar como a doutrina clássica encara o caso tomado como exemplo. Em primeiro lugar, nota-se que todas as nuances da atividade enunciativa são deixadas de lado por parte dos processualistas ao tratarem dos fatos no processo. Desse modo, em geral, as peculiaridades das limitações redacionais e a impossibilidade de se formularem enunciados fáticos

\footnotetext{
${ }^{180}$ A convivência é um fato contínuo, que se protrai no tempo. Um fato porque se encontra no plano fenomênico. Se protrai no tempo por não se poder reduzi-la a uma estrutura de coordenada temporal específica definida como T. Fazendo-se uma analogia com a matemática, a convivência é uma reta, composta por um sem número (infinitos) de pontos equiparáveis às frações temporais. Um ponto não é capaz de definir a reta, tal qual um acontecimento da vida não pode definir uma convivência. Para aprofundamentos, TARUFFO; Considerazioni sul prova e verità, cit., pp. 280 e ss..

181 Quanto ao fenômeno da indivisibilidade de alguns fatos complexos, com maiores e mais profundas exemplificações, TARUFFO, La prueba de los hechos, cit., pp. 146 e ss. Pela perspectiva clássica da doutrina, chegando a conclusões opostas, DinAMARCO, Ônus de afirmar, cit. p. 225, diz: "de um lado, o juiz não pode levar em conta fatos não alegados na petição inicial (art. 128) e esta será inepta se não alegar todos os fatos dos quais depende a constituição do direito alegado pelo autor”. Porém, pela ótica epistemológica, nenhum fato, nem mesmo os simples, podem ser narrados em sua inteireza; tampouco os fatos complexos podem ser enunciados em todos os seus componentes mini-fatos.

${ }^{182}$ É possível pensar em uma situação em que um único fato pudesse tornar a convivência intolerável. Uma traição, por exemplo, dentro de um determinado contexto religioso, poderia ser suficiente para criar uma instabilidade intolerável. Nesse caso, a identificação dos fatos seria simples e sem maiores problemas. O que se busca mostrar, entretanto, é que na maioria dos casos é um conjunto de acontecimentos, protraídos no tempo, que formam a causa da vontade de um dos cônjuges em se divorciar. Conjunto esse, contudo, impossível de ser reproduzido em sua inteireza em uma peça processual por meio de narrações.
} 
exaurientes sobre os acontecimentos da vida não são levadas em consideração. Assim sendo, a doutrina majoritária reduz o instituto da causa de pedir às alegações do autor (para ser preciso, de seu advogado ${ }^{183}$. No que se refere aos fatos complexos, isso gera inúmeros problemas e contradições, pois se abandona a totalidade do fato posto à base da crise para qual se pede solução considerando-se tão somente os aspectos expostos no ato introdutório.

É de se destacar que não se está tratando aqui do embate da chamada lide integral e lide parcial, referida por CARNELUTTI. Tampouco são pertinentes as críticas formuladas por CALMANDREI sobre a inexistência dessa dualidade, tendo em vista que, segundo ele, somente aquilo que fosse introduzido no processo pelo autor é que comporia a lide, sendo, pois, todas as lides completas ${ }^{184}$. Isso pelo simples fato de que, também ele, ignorou toda a perspectiva epistemológica dos enunciados fáticos, suas limitações e restrições, bem como realizou a simplificação dos fatos como sendo uma entidade simples e bem delimitada. Todas as especificidades do ato narrativo que aqui se busca destacar eram, portanto, ignoradas pelo processualista italiano citado.

No caso da ação de divórcio invocada, aduz-se, em geral, que se o autor fundasse sua demanda em convivência intolerável, alegando, por exemplo, que o marido alcoolizava-se e, por isso, cometia violências diariamente, não poderia em momento posterior alterar seu conjunto descritivo para embasar o pedido constitutivo negativo em violação dos deveres do casamento, mesmo que restasse comprovado nos autos que um dos cônjuges tivesse praticado adultério. Por outro lado, atenuando a rigidez do posicionamento, mas mantendo a coerência interna do raciocínio e as premissas iniciais adotadas, defendem os pensadores clássicos que o autor, caso não obtivesse a procedência da demanda original proposta, poderia re-propor a ação de divórcio fundada na violação dos deveres conjugais por adultério, sem que o cônjuge pudesse alegar existência de coisa

\footnotetext{
${ }^{183}$ Parte da doutrina é expressa em adotar um conceito de causa petendi restrito aos estritos limites das alegações do autor, isto é, aos limites do ato formal narrativo. Nesse sentido, em recente estudo, GIAN FRANCO RICCI, Questioni controverse in tema di onere della prova, in Riv. dir. proc., 2014, n.2, pp.321 e ss.. Outros estudiosos, por seu turno, ampliam o conceito e tratam a causa de pedir como o fato trazido pelo autor, fato este tido com 'bruto' e analiticamente delimitado, podendo-se considerar também elementos não contidos na narração, mas sempre limitados ao acontecimento individualizado e deduzido em juízo. Entretanto, relegando a um segundo plano a complexidade de alguns tipos de fatos, somente estaria circunscrito à causa petendi os aspectos (pedaços) destacados pelo autor na inicial, isto é, as facetas eleitas por ele componentes do acontecimento complexo. Nesse sentido: BARBOSA MOREIRA, Considerações sobre a causa de pedir na ação rescisória, in Temas de Direito Processual, 4a Série, São Paulo, 1989, p. 211; DINAMARCO, Ônus de afirmar, cit., pp. 224-225.

${ }^{184}$ Litis y proceso, cit., pp. 286 e ss.
} 
julgada, vez que as causas de pedir das duas ações seriam diversas e, conseqüentemente, as demandas distintas. ${ }^{185}$

O posicionamento, primeiramente, vincula o instituto da modificação da demanda à técnica de individualização da ação por meio dos três requisitos clássicos - frise-se: já contidos no ato introdutório do autor-, quais sejam: causa petendi, petitum e partes, como faz grande parte da doutrina. Em segundo lugar, considera como causa de pedir da demanda tão somente o fato narrado pelo autor em sua petição inicial, bem como definitiva a qualificação jurídica feita por ele próprio (leia-se, seu advogado) nessa mesma peça processual. No caso, os fatos da embriaguez e da violência, qualificados como responsáveis pela convivência intolerável, são imutáveis ao longo do processo. ${ }^{186}$

É de se notar, abrindo-se aqui um parêntese, que a qualificação jurídica e a identificação da fattispecie normativa possuem, segundo a visão clássica, caráter ontológico, e não semântico. Um estudo mais aprofundado quanto à identificação do suporte fático normativo será traçado no tópico seguinte. Contudo, pode-se adiantar aqui que a individualização da abstrakte Tatbestand é uma atividade interpretativa, e que por isso, não obstante siga parâmetros e regras, possui certa variabilidade e mobilidade, apresentando também ela um caráter dinâmico, visão contrária à noção estática apresentada pela visão clássica.

Retomando, o raciocínio desenvolvido pelos processualistas tidos como clássicos, é bem verdade, apresenta uma enorme coerência interna, tal como já dito. Ademais, a autorização de nova propositura parece ser o elemento de equilíbrio que atribui justiça ao caso dos cônjuges (seria inaceitável perpetuar um matrimônio não desejado por um de seus membros por formalidades e preclusões processuais, sendo que o direito material do autor havia sido comprovado naquela primeira ação). Porém, era uma exigência demasiadamente pesada obrigar o autor, que já havia de certa forma demonstrado razões suficientes para

\footnotetext{
${ }^{185}$ Fazendo referência a esse raciocínio, CRUZ E TUCCI, A causa petendi no processo civil, cit., pp. 224-226.

${ }^{186}$ Nota-se, pois, que todas as especificidades e limitações do ato narrativo são relegadas a um segundo plano pelos estudiosos do processo. A complexidade dos acontecimentos e as posições epistemológicas do ato enunciativo são substituídas por conceitos meramente processuais, dotados de um artificialismo e simplificações que mais geram problemas do que soluções. No caso da ação de divórcio, os acontecimentos da vida são tomados como algo analiticamente delimitado, claro e absoluto, se consubstanciado em uma causa de pedir simples, se referido a um "evento" unitário, ou causa de pedir composta, se narrados vários fenômenos. As construções e desconstruções feitas pela narrativa, bem como suas limitações intrínsecas, não são consideradas. Fazendo menção à doutrina clássica e apontando os reflexos na jurisprudência, CRUZ E TUCCI, ibidem, p. 194.
} 
obter o divórcio, a arcar com todos os ônus e obrigações de uma improcedência, bem como mantê-lo em um status civil - com todas as conseqüências daí advindas - até que pudesse obter em outra ação a tutela almejada. ${ }^{187}$

Contudo, segundo o que se expôs até aqui no trabalho, é possível trazer como fator de análise a natureza complexa da "convivência intolerável" e sua integralidade à base da demanda, as limitações naturais do ato enunciativo, a impossibilidade da descrição exauriente de toda uma convivência, a natureza parcial e incompleta do ato introdutório, bem como, muitas vezes acontece, o potencial posicionamento epistemológico de desconhecimento da integralidade do fato por parte do narrador, o que acarretaria ao caso em lume uma solução distinta daquela proposta.

Tomado pela perspectiva aqui adotada, o adultério seria encarado como apenas um dos eventos, dentre inúmeros outros, componentes da convivência entre cônjuges, ou seja, ele seria tido como apenas uma parte do fato complexo alegado. Além disso, dentro de um determinado contexto, a relação sexual com terceiros pode causar, e geralmente causa, uma intolerabilidade entre marido e mulher, o que, nessa circunstância, manteria inclusive a qualificação jurídica tal como originariamente proposta (de resto, vale lembrar, também provisória). ${ }^{188}$

Em conclusão parcial, pode-se afirmar que, seja por violação dos deveres conjugais, seja por convivência intolerável entre os cônjuges, a crise de direito material e a insatisfação de um dos sujeitos é sempre a mesma, variando tão só a estratégia redacional e

${ }^{187}$ É de se ressaltar mais uma vez que o raciocínio clássico exposto é internamente, de fato, muito coerente. Se se adota como causa de pedir tão só a face do fato complexo exposta pelo autor, e essa é responsável pela identificação da demanda, então sua alteração gera, fatidicamente, sua modificação. Logo, se essa ação é julgada improcedente, basta que se altere a faceta fática do fato complexo (e, portanto, toda a demanda) para que se saia dos limites objetivos da coisa julgada anterior. Contudo, ao que parece, não obstante se resolvam os problemas de lógica interna, isto é, de técnica processual, a solução parece relegar a um segundo plano de importância a insatisfação dos sujeitos, que, mesmo tendo tido o direito comprovado, deverão manter-se na condição da crise existente antes da propositura da demanda, tendo sido o processo, pois, incapaz de atingir o seu fim. A reforma da legislação da Itália do ano de 2009, país no qual também essa visão de causa de pedir predomina, em busca de um equilíbrio entre formalidades e justiça, flexibilizou o regime preclusivo e, seguindo julgados da Corte de Cassação, afastou a obrigação dos cônjuges em se apresentarem diante do presidente da fase introdutória com todas as demandas já necessariamente propostas. Em outros termos, o legislador peninsular autorizou as partes a, gradativamente, alegarem os fatos que dão suporte às suas pretensões e, nesse sentido, a identificação da demanda passou não mais a se dar na primeira manifestação dos envolvidos. Para aprofundamentos quanto às modificações nesse rito, ver LuISO, La nuova fase introduttiva del processo di separazione e diverzio, in Il giusto processo civile, ano 1, n. 3, 2006, pp. 41 e ss, especificamente sobre o ponto, p. 47.

${ }^{188}$ Apontando o caráter provisório da qualificação jurídica contida na inicial e sendo ela mera sugestão das partes ao juízo, DINAMARCO, Instituições, cit. p. 132. 
processual daquele que confeccionou a peça introdutória. Condicionar a decisão do caso, isto é, a procedência ou improcedência da demanda, à redação da peça inicial (de caráter extremamente variável), ao menos aos olhos de quem escreve e diante dos inúmeros elementos epistemológicos até aqui expostos, parece uma técnica equivocada.

A fim de deixar claro o que se defende, invocar-se-á outro caso simbólico, bastante usado pela doutrina e portador de inúmeras controvérsias quando se trata do tema da modificação da demanda, sendo também ele referente a um fato complexo. Trata-se, nesse sentido, dos casos nos quais a administração de sociedades empresárias reside como fato posto à base do litígio apresentado pelo autor.

Tal como a convivência, a administração de uma empresa (ou qualquer administração de outra natureza) constitui uma atividade composta de inúmeros comportamentos e condutas diluídos ao longo de um lapso temporal. Como é intuitivo, uma administração não se faz por meio de um único ato ou alguns atos isolados, mas por uma seqüência permanente de atos combinados que formam um conjunto chamado administração. Nesse sentido, tal atividade é considerada como um 'fato complexo', que pode ser decomposta em um sem número de 'mini-fatos' simples, mas que só será administração se considerada em sua inteireza. ${ }^{189}$

Logo, pensando em uma demanda na qual o substrato da insatisfação seja os deveres do administrador ${ }^{190}$, que, no exercício de suas funções, deve ter o cuidado e a diligência que todo homem ativo e probo costuma empregar na administração de seus próprios negócios (art. 1011 do CC), intuitivo concluir que o autor não deverá narrar em sua peça introdutória todos os seus atos e condutas existentes durante o período em que administrou a empresa para que sua inicial seja aceita, tampouco deverá provar que todos eles foram permeados pela probidade e diligência exigidas em lei para que obtenha uma sentença favorável.

Por outro lado, se tomada como objeto de análise uma ação de dissolução parcial de sociedade, cumulada com pedido de exclusão do sócio administrador, o autor deverá em seu ato introdutório do processo apontar quais condutas configurariam uma suposta

\footnotetext{
${ }^{189}$ Nesse mesmo sentido, TARUFFO, La prueba de los hechos, cit., pp. 145-146; GAMBA, Diritto societario, cit., pp. 425 e ss.

${ }^{190}$ Reconvenção, por exemplo, proposta por um sócio para reconhecimento de sua atuação com probidade na atividade administrativa e sua conseqüente manutenção na administração da empresa ante a ação de dissolução parcial de sociedade empresária combinada com pedido de exclusão de sócio administrador.
} 
temeridade de gestão - ou, para usar o termo da doutrina clássica, deverá indicar quais os fatos comporiam a chamada causa petendi passiva. Nesse exemplo proposto, é possível pensar em uma situação na qual um ato isolado configure em si a justa causa prevista em lei para a exclusão do sócio e para que dê azo à dissolução parcial da sociedade empresária. Um único desfalque milionário no caixa da empresa para benefício individual do administrador, por exemplo, é um acontecimento facilmente subsumível à fattispecie do art. 1.030 do Código Civil como sendo autorizativo da exclusão do autor da conduta. Nesses casos simples, não há maiores dificuldades para que os sujeitos do processo, seja em seus atos enunciativos parciais seja para a fundamentação da sentença, identifiquem quais acontecimentos devem ser descritos e provados.

Contudo, como a experiência costuma demonstrar, casos que envolvem a administração empresária são permeados por uma enorme complexidade, não sendo, pois, redutíveis ao esquema simplificado de fato $\mathrm{X}$, momento $\mathrm{M}$, local $\mathrm{L}$.

Nesse sentido, os tribunais e parte da doutrina têm freqüentemente entendido que o Código Civil atual, ao regulamentar a dissolução parcial societária e a exclusão de sócio administrador, previu que não basta o mero rompimento da chamada affectio societatis, mas a condução da pessoa jurídica deve apresentar condutas que configurem a dita justa causa, tida como "o não-cumprimento ou a impossibilidade de o sócio adimplir seus deveres essenciais, inviabilizando ou colocando em risco a continuidade da própria atividade social". 191

Assim sendo, ao se tratar de um fato complexo, não individualizável analiticamente em coordenadas temporais e espaciais, surgem os problemas enunciativos já expostos. Da mesma maneira que na ação de divórcio, ao usar como substrato fático da crise o não cumprimento pelo sócio dos seus deveres essenciais, o autor não deve trazer todos os acontecimentos existentes (como já dito, algo impossível) a fim de que sua demanda possa ser aceita, tampouco deverá provar todas as condutas inidôneas do administrador para que a ação seja procedente. Basta que o indivíduo insatisfeito enuncie em sua inicial alguns

\footnotetext{
${ }^{191}$ FRANÇA e ADAMEK, Affectio societatis: um conceito jurídico superado no moderno direito societário pelo conceito de fim social, in Revista de Direito Mercantil Industrial, Econômico e Financeiro, 2008, v. 149-150, pp. 108 e ss.. No mesmo sentido, STJ, REsp n ${ }^{\circ}$ 1.129.222-PR, Terceira Turma, Rel. Min. Nancy Andrighi, j. 28.06.2011; TJSP, Apl. 0045715-81.2007.8.26.0564, 9 ${ }^{\text {a }}$ Câmara de Direito Privado, Rel. Des. Piva Rodrigues, j. 19.08.2014, DJe. 22.08.2014; TJSP, AI 2040543-60.2013.8.26.0000, $1^{\text {a }}$ Câmara Reservada de Direito Empresarial, Rel. Des. Alexandre Marcondes, j. 20.03.2014, DJe. 28.03.2014; TJSP, Apl. 994.03.036131-4, 8 Câmara de Direito Privado, Rel. Des. Caetano Lagrasta, j. 03.02.2010, DJe. 12.02.2010.
} 
fatos capazes de comprovar que a administração exercida pelo sócio administrador apresentava temeridade e trazia riscos à vida econômica da pessoa jurídica, os quais, segundo o art. 1.030 do CC, configurariam falta grave no cumprimento das obrigações.

Não obstante a entrada seletiva dos acontecimentos por meio das atividades enunciativas no âmbito do processo, importante notar que a crise exposta - e para qual se pede uma solução - tem em sua base um 'fato complexo' impossível de ser descrito em sua integralidade, mas que é fundamental ser compreendido em sua máxima extensão e profundidade para a correta decisão. Não é apenas pelo fato $\mathrm{X}$ ou pelo acontecimento $\mathrm{Y}$, em geral, que os autores de uma demanda de dissolução parcial estão insatisfeitos. A insatisfação advém de toda uma administração temerária, isto é, é oriunda de todo o conjunto de comportamentos e condutas do administrador durante os anos.

Aliás, quanto ao ponto - que será aprofundado mais adiante -, é importante notar que, em muitos casos, por uma visão permeada pelas diretrizes clássicas de abordagem do tema, os tribunais têm dado decisões que não são capazes, ainda que comprovado o direito da parte, de solucionar a questão posta pelos sujeitos insatisfeitos, tudo pela simples razão formal de restrição do conceito de causa de pedir aos 'mini-fatos' alegados pelo autor, deixando de lado as peculiaridades do ato enunciativo e a incapacidade intrínseca de se narrar à exaustão o fato complexo.

Apenas a título exemplificativo, trar-se-á à baila para análise um caso julgado pelo Egrégio Tribunal de Justiça de São Paulo ${ }^{192}$, no qual um dos administradores, sócio proprietário de $50 \%$ das quotas sociais de uma sociedade limitada, e a própria empresa propõem ação de dissolução parcial, cumulada com pedido de exclusão de sócio, em face da outra administradora, ex-esposa do autor e proprietária dos $50 \%$ das quotas restantes, tudo sob a alegação de que ela, ré, cometera fatos graves que levaram à quebra da affectio societatis. Tais condutas seriam, em síntese: a) a administração da sociedade exclusivamente pelo sócio até o divórcio do casal, momento no qual a sócia começou a se interessar pela empresa; b) recontratação de funcionários que foram demitidos pelo autor tão só com a intenção de afrontá-lo e dificultar suas atividades administrativas; c) alteração pela ré de várias determinações feitas por ele, autor, sem seu prévio consentimento; e d) contratação por ela, sócia, também sem a anuência de seu ex-marido, de uma segunda

${ }^{192}$ Apl. 9000025-65.2011.8.26.0100, $1^{\text {a }}$ Câmara Reservada de Direito Empresarial, Rel. Des. Francisco Loureiro, j. 04.07.2013, DJe. 12.07.2013. 
equipe de vendas. Pleiteou, pois, a dissolução da sociedade e a exclusão de sua ex-mulher dos seus quadros empresários.

A ré, de sua parte, contestou a demanda dos autores e, contra eles, propôs reconvenção fundando-se no fato de que são inverídicas as alegações do sócio de que ela não participava da administração da empresa antes do divórcio, fato que, segundo sua visão, configuraria falta grave a ponto de autorizar a exclusão do sócio.

A demanda foi julgada procedente em primeira instância, ao passo que a reconvenção teve julgamento de improcedência pelo juízo de primeiro grau. Houve interposição de recurso de apelação pela ré, que alegou, dentre outras coisas: a) sempre administrou a empresa, ainda que atuando em departamento diverso daquele de seu exmarido; b) que o sócio visava à exclusão da ré tão só para dilapidar o patrimônio da empresa; e, em caráter inovatório, c) que uma auditoria realizada por empresa terceira em setembro de 2011 constatou a existência de sonegação físcal da ordem de $\mathrm{R} \$$ 17.013.447,49, referentes a declarações de imposto de renda, bem como houve desfalque no caixa da empresa em mais de onze milhões de reais pela ausência de escrituração da saída de cheques neste montante. Pleiteou, assim, a reforma integral da sentença para julgar improcedente a ação dos apelados e procedente a sua reconvenção.

O órgão julgador, na linha do voto do condutor, entendeu que o recurso comportava parcial provimento. No que tange à ação de dissolução de sociedade proposta pelo sócio e pela sociedade, os magistrados de segunda instância entenderam que a sócia comprovou que exerceu a atividade administrativa muito antes do divórcio, ainda que em setor diferente de seu ex-marido (ele na área financeira, ela na comercial), bem como que as condutas imputadas à ré pelo seu ex-cônjuge na inicial não seriam capazes de se conformar ao conceito de justa causa trazido pelo Código Civil, já que, também ela, segundo o contrato social, tinha o poder de administrar a empresa. Nesse sentido, reformou-se a sentença para julgar improcedente a demanda dos autores.

No mesmo sentido da decisão monocrática, os julgadores, naquilo que concerne à reconvenção, entenderam que o simples fato de o sócio imputar condutas temerárias à apelante, mesmo sendo as afirmações inverídicas, não consubstanciaria justa causa para a dissolução da sociedade empresária, bem como não comportaria a exclusão de seu exmarido dos quadros sociais. 
Entretanto, e esse é o ponto que interessa ao presente estudo, o acórdão consignou que as acusações feitas pela ré ao autor-apelado (teria ele sonegado $\mathrm{R} \$ 17.013 .447,49$, bem como teria desfalcado o caixa da empresa em mais de onze milhões de reais pela ausência de escrituração da saída de cheques) seriam, em tese, aptas à procedência da reconvenção, bem como reconheceu expressamente que não haveria óbices formais para se juntar em grau de apelação novos documentos comprobatórios das condutas temerárias do apelado (laudos feitos por empresas terceiras que constatavam a sonegação), vez que há previsão autorizativa nesse sentido no código de processo (art. 397) e que estaria configurada a justa causa para a falta de juntada no momento da propositura da reconvenção (documentos produzidos em momento posterior). Não obstante isso, os desembargadores julgaram improcedentes os pedidos formulados na peça reconvencional.

E isso foi feito, segundo eles, pois "a ré inova na causa de pedir de sua reconvenção em momento no qual as regras de estabilização da demanda presentes no ordenamento processual não mais admitem uma ampliação dos fundamentos de fato e de direito e do objeto da lide ${ }^{\# 193}$. Em outros termos, manteve-se a sociedade com sua configuração e administração originária, tal como o vínculo societário entre os litigantes insatisfeitos, tudo porque a demanda estava estabilizada e não comportava alterações na dita causa de pedir remota. Ressalta-se que o julgado ignorou a natureza complexa do fato, bem como não considerou que, estando excluída da administração financeira da empresa, a ré, autora da reconvenção, possuía uma posição epistemológica de 'leitora não informada' - usando aqui a terminologia já referida - quanto à integralidade das circunstâncias de fato existentes, o que a impediria de traçar enunciações mais precisas quanto ao cenário fático no momento da propositura da ação reconvencional. ${ }^{194}$

\footnotetext{
${ }^{193}$ Destaca-se que os apelados tiveram oportunidade de se manifestarem em relação aos documentos em suas contra-razões de apelação, tendo sido a eles garantido o contraditório, mas que, segundo se extrai do relatório do acórdão, os laudos e documentos não foram impugnados.

${ }^{194}$ Quanto ao ponto, inclusive, o caso traz ainda um agravante. Em geral, o 'leitor não informado' pode aumentar seu grau de conhecimento quanto às circunstâncias de fato por inúmeros meios, tanto extrajudiciais quanto judiciais (ação de exibição de documentos, art. 844, produção antecipada de provas, art. 846, ambos do CPC, por exemplo). Entretanto, em situação especial, a ré havia tão somente o prazo de 15 dias contados a partir da citação para propor sua reconvenção (art. 299, CPC). Logo, sem tempo hábil para se aprofundar quanto aos limites da temeridade da administração, foi obrigada a confeccionar sua demanda de forma genérica.
} 
A parte uma visão doutrinária alargada do conceito de direito superveniente ${ }^{195}$, que, de certa forma, poderia ser capaz, por si só, de resolver o caso com maior justiça e aderência à realidade do conflito, nota-se que a interpretação epistemológica de 'fato complexo' pode conferir ao caso uma decisão mais justa. ${ }^{196}$

Em ambos os exemplos pode-se notar uma constante extensíveis às mais diversas situações que envolvem demandas fundadas em fatos da mesma espécie: a complexidade do fato, por sua própria natureza, permanece em grande parte fora do processo, tendo em vista as inúmeras limitações dos atos enunciativos e das posições epistemológicas dos sujeitos processuais. Entretanto, o fato complexo está como pressuposto e constitui a base ou substrato (background) sobre o qual se funda a controvérsia, não podendo ser ignorado em seus limites externos pelo julgador, sob pena de se incidir no fenômeno indesejado da “indiferença da decisão" quanto à realidade crise. ${ }^{197}$

Para os fins do presente trabalho, de tudo o que fora dito, deve se destacar que há uma limitação na abordagem dos fatos complexos feita pela perspectiva tradicional, dita aqui clássica, que restringe o conceito de causa de pedir apenas às faces alegadas e destacadas pelas partes em suas manifestações processuais. Em outras palavras, a causa petendi exposta na petição inicial se limita tão somente às partes destacadas de forma parcial e incompleta pelo autor, deixando de lado toda complexidade existente do

\footnotetext{
195 Estudo aprofundado, com ampla indicação bibliográfica, relacionando direito superveniente à eficácia jurídica superveniente ou dedução superveniente, LEONEL, Causa de pedir e pedido: o direito superveniente, cit. pp. 231 e ss. e pp. 250 e ss.

${ }^{196}$ Evidentemente que o laudo trazido pela autora da reconvenção, por si só, não seria um fator irrefutável de procedência da demanda. Poderia perfeitamente o órgão-julgador, ao analisá-lo, concluir pela sua insuficiência probatória. Contudo, o ponto-chave que interessa ao trabalho é que, no caso em análise, o meio de prova não foi sequer analisado. Os juízes nem mesmo se propuseram a fazer um juízo de fato quanto ao 'pedaço' do evento complexo alegado pela apelante, tudo por uma única razão: tomando como componente da causa de pedir um acontecimento isolado (que, destaque-se, por si só jamais seria real motivo de insatisfação da sócia), portanto, com limites restritos, entenderam que a demanda estava estabilizada, o que inviabilizaria tomar em consideração outros fatos, mesmo que eles fossem epistemologicamente componentes da mesma gestão temerária alegada e potencialmente pudessem alterar o sentido do julgamento da causa. Favorável à tese aqui defendida, mas por outros argumentos, COSTANZO M. CEA, Le nuove prove in appello, in Giusto Processo Civile, n. 3, 2006, pp. 103 e ss.. Em sentido contrário ao da conclusão aqui exposta fundando-se em pretensa quebra de imparcialidade do juiz, ver CIVININI, Poteri del giudice e delle parti nel processo ordinario di cognizione. Rilevo ufficioso delle questioni e contraddittorio, in Foro it., parte V, p. 7.

${ }^{197}$ O tema da 'indiferença da decisão' será objeto de análise pormenorizada mais adiante. Contudo, quanto à necessidade de se levar em consideração o substrato fático que restara fora dos limites processuais, sob pena de um descolamento da decisão quanto aos reais limites do conflito, ver: ENRIQUES, Do Corporate Law Judges Matter? Some Evidence from Milan, in European Business Organization Law Review, 2002, pp. 765 e ss; GAMBA, Diritto societario, cit., pp. 115, 157 e ss.; TARUFFO, Idee per una teoria della decisione giusta, in Sui Confini, Bolonha, 2002, pp. 226 e ss..
} 
substrato fenomênico posto à base da crise. A razão dessa redução conceitual pode ser atribuída a uma interpretação restritiva do princípio dispositivo e do princípio da correlação entre pedido e sentença. Maiores aprofundamentos quanto a eles serão traçados em sede própria. Contudo, parece inegável o fato de que essa maneira de encarar os fatos complexos causa, com maior ou menor grau, uma incoerência no plano substancial.

Todavia, levando-se em consideração aspectos geralmente abandonados pela doutrina e jurisprudência, é possível perceber que os conflitos trazidos ao judiciário, em geral, apresentam complexidade muito maior do que aquela enclausurada no ato introdutório. Isso pelas razões já expostas: limitação intrínseca das narrativas ao reproduzir os acontecimentos do plano concreto, parcialidade na produção dos enunciados e na estruturação da peça inicial, caráter provisório e incompleto da peça introdutória e filtragem parcial pelas normas de apenas alguns aspectos dos fatos complexos.

Ressalta-se que essa distância existente entre os atos processuais e o cenário em que se insere a crise entre os sujeitos gera, de certa forma, um descolamento entre a decisão e a insatisfação, desaguando, muitas vezes, no fenômeno da 'demanda sem resposta'. Um processo que visa a resultados, isto é, que busca a justiça da decisão, exige uma nova abordagem dos fatos complexos no âmbito do processo, tudo a fim de aproximar as condições reais do substrato fático da representação enunciativa processual feita pelas partes, impactando, com isso, diretamente no conteúdo da sentença.

Entretanto, afirma-se que essa aproximação não pode se dar de forma alargada, ignorando-se o sistema posto. Princípios e regras do processo devem ser observados. O tema dos limites do instituto da modificação da demanda será objeto de estudo em tópico seqüente. Todavia, quanto ao tema, é de se destacar que para que uma face do fato complexo possa ser levada em consideração pelo juiz em sua decisão, obrigatoriamente ela deve ter sido objeto de alguma enunciação no processo. Em outras palavras, os 'mini-fatos' - componentes do acontecimento complexo - devem estar presentes no conjunto de enunciados fáticos sobre o qual o juiz pode se manifestar, conjunto esse formado por enunciações feitas não só pelas partes, mas também por testemunhas, peritos ou mesmo advindas de documentos juntados aos autos ${ }^{198}$. O mini-acontecimento, pois, deve ser objeto de um enunciado qualquer formulado dentro do processo.

${ }^{198}$ Para aprofundamentos quanto à formação do conjunto de enunciados que serão objeto do juízo de fato do juiz, ver: TARUFFO, Elementi per um'analisi, cit., pp. 246 e ss; GAMBA, Diritto societario, cit. pp. 400 e ss. 
Destarte, é possível adiantar que não cabe ao juiz formular ex officio enunciados hipotéticos sobre fatos (simples ou complexo) ou destacar faces componentes dos fatos por sua livre e espontânea vontade. O código de processo veda essa atividade, salvos algumas raras exceções, de enunciação originária por parte do julgador.

Feitas essas observações, conclui-se que os fatos, tidos como acontecimentos concretos, possuem em si uma complexidade que não podem ser reproduzidas em sua inteireza no processo. Limitações intrínsecas ao ato redacional e à atividade enunciativa impedem que todas as nuances dos eventos sejam trazidas para análise do julgador, nuances essas que podem, em tese, ser fundamentais para julgamento do caso. Somando-se a isso o posicionamento de envolvimento das partes, pode-se concluir que o ato introdutório, tal qual o ato inicial de defesa, possuem caráter parcial e incompleto, além de possuir elementos potencialmente falsos, que devem ser levados em consideração pelos processualistas.

Dito isso, pode-se, nesse momento, prosseguir com o raciocínio e destacar alguns outros elementos que são fundamentais para o tema em debate, elementos epistemológicos referentes aos fatos no processo e sua relevância nesse âmbito geral, na petição inicial e peças de defesa, bem com para o conjunto de representação enunciativa advindo das partes e demais sujeitos que nele atuam.

\subsubsection{O fato e sua relevância}

O presente item do texto é destinado a tratar da relevância que os fatos possuem dentro do contexto processual, em específico, a relevância dada a alguns fatos pelo autor (leia-se: seu advogado) durante a formulação da petição inicial, e pelo réu em sua contestação, tema que já foi superficialmente abordado anteriormente, bem como a relevância dada a alguns acontecimentos dentro da decisão - tema que será aqui tratado somente de forma introdutória e desenvolvido em item específico mais adiante -, tudo com o foco na potencial variabilidade dessa importância ao longo do processo.

Como se verá, os fatos podem ter sua importância alterada com o desenvolvimento processual, o que aponta para uma 'provisoriedade' e 'instabilidade' da estrutura dos fatos da demanda montada no ato introdutório pelo autor e no ato defensivo pelo réu. Nesse 
sentido, corroborando o que fora dito em momento precedente, a demanda não possui um caráter estático. Os limites da crise sobre a qual o juiz deve se manifestar não são expostos com certeza e determinação já nas manifestações iniciais das partes. Os recortes da realidade feitos pelos advogados conforme os níveis de relevância dos fatos podem - e geralmente são - mais um fator dinâmico da demanda.

Antes, entretanto, importante retomar algumas observações que foram feitas no capítulo anterior destinado à análise das visões da doutrina clássica e da jurisprudência quanto aos critérios e limites aceitos para a modificação dos fatos e pedidos no curso do processo.

Como se viu, parte dos processualistas, tanto no Brasil como no exterior, crê que a modificação dos elementos objetivos da demanda é autorizada se - e somente se - tal atividade não implicar em uma mutatio libelli. Em outros termos, a alteração dos fatos e dos pedidos é permitida dentro dos limites da assim denominada emendatio libelli.

Deixando de lado os pormenores dos critérios diferenciadores entre uma e outra categoria - tema já desenvolvido anteriormente -, ressalta-se que a doutrina, seguida pelos tribunais, freqüentemente coloca como pilar de sustentação entre a mudança e a mera emenda da demanda os fatos constitutivos (principais) alegados pelo autor. Tais fatos, segundo a visão tradicional, não poderiam ser objeto da atividade modificativa, quer pelas partes quer pelo juiz, ao passo que os ditos fatos secundários (indiciários) seriam livremente modificáveis pelos sujeitos do processo. Isso seria possível pelo motivo de que estes não comporiam a causa de pedir do autor. Já aqueles, por outro lado, seriam os responsáveis por formar a causa petendi e, conseqüentemente, identificar a demanda: alterá-los, pois, implicaria obrigatoriamente na mudança da causa de pedir e, como seqüência, da demanda inicialmente proposta.

Partindo de uma análise simplória e superficial dos fatos, essa visão tradicional parte de um pressuposto silogístico da individualização dos fatos postos à base da decisão. Para ela, o autor expõe os acontecimentos fáticos e a eles atribui uma consequiência jurídica contida em uma determinada norma. O réu, por sua vez, além das demais defesas possíveis ${ }^{199}$, apresentaria fatos impeditivos, modificativos ou extintivos do direito buscado. O juiz, por seu turno, após a fase instrutória, verificaria quais fatos foram provados e, a

${ }^{199}$ Para as várias formas de defesa, ver: COMOGLIO, FERRI, TARUFFo, Lezioni sul processo civile, Bologna, 2011, v. I, p. 297 e ss. 
depender da conclusão, proferiria uma sentença que diria se a norma é ou não aplicável ao caso concreto.

Ocorre, porém, que o juízo de fato e a correspondente aplicação da norma constitui operação bem mais complexa que isso, sendo fruto de um processo decisório que será tratado adiante. $\mathrm{O}$ que importa ressaltar por ora é que essa perspectiva impõe um caráter estático ao critério de relevância dos fatos. Para os seguidores desse raciocínio, os fatos tidos pelo autor como principais - repita-se, tomados por um critério normativo fruto de uma escolha parcial e ilocutória do sujeito envolvido - serão sempre principais e, desse modo, aqueles tidos por secundários serão sempre secundários, o que, como se verá, não corresponde à realidade.

Essa visão silogística, não obstante tenha apontado que o critério de relevância em um contexto processual se dá por meio da norma, é passível de inúmeras críticas, que serão desenvolvidas a seguir ${ }^{200}$. Contudo, cabe aqui ressaltar que tal pensamento é responsável por uma drástica redução da função e da capacidade representativa da decisão, bem como ignora o complexo processo decisório e construtivo das premissas maiores e menores realizado pelo juiz, atribuindo um caráter estático à relevância factual ao longo do processo, algo incompatível com o que realmente acontece.

Em prosseguimento, falou-se alhures que uma das espécies de construção dos enunciados fáticos é aquela que foi chamada de seletiva, isto é, a construção na qual o narrador escolhe alguns acontecimentos de acordo com a relevância que eles possuem dentro de sua narrativa. No âmbito de um processo, o critério utilizado para afirmar que algo é ou não é relevante advém da norma. É a norma jurídica que funciona como standard para que se defina um fato como importante ou não.

Foi dito, outrossim, que as normas possuem em sua estrutura um suporte fático normativo, também chamado de fattispecie ou ainda abstrakte Tatbestand. É justamente essa previsão abstrata de um acontecimento e a imposição de efeitos jurídicos a ele que atribui a um fato a relevância. Baseado na norma que interessa ao cliente, o advogado seleciona os fatos que serão destacados em seus enunciados.

Entretanto, enganam-se aqueles que acreditam que o tema, da maneira como foi exposto, não apresenta qualquer problema ulterior. Em primeiro lugar, deve-se questionar

${ }^{200}$ Apenas a título introdutório, por todos: TARUFFO, La motivación de la sentencia civil, Madrid, 2011, pp. 151-168. 
como tais normas são eleitas pelos narradores, isto é, pelos advogados. Ademais, a simples afirmação de que os fatos relevantes são aqueles previstos pelas normas, tal como muitas vezes a doutrina trata o assunto, não resolve o imbróglio, já que várias são as formas como elas, as normas, configuram suas premissas fáticas, não havendo nada mais discutível e confuso que a ideia simplória de que há uma definição simples, clara e unitária do que constitui o fato previsto pelas leis. ${ }^{201}$

Com relação ao primeiro ponto levantado, relativo à escolha da norma, deve-se, primeiramente, fazer referência ao fato de que o CPC brasileiro exige - exigência essa, de resto, existente na maioria dos códigos processuais ${ }^{202}$ - que o autor exponha em sua inicial o fundamento jurídico de sua demanda.

Sabe-se que o advogado do autor não pode simplesmente expor os fatos como seu cliente lhe passara e requisitar o bem da vida. Deve, isso sim, fazer remissão a institutos jurídicos, demonstrar que a situação concreta encaixa-se em uma determinada previsão normativa, que as conseqüências jurídicas ali abstratamente previstas se aplicam ao caso e, só então, requisitar a tutela jurisdicional que, em tese, seria apta a resolver o litígio.

Porém, muitas vezes a doutrina relega a um segundo plano ou mesmo nem sequer enfrenta o problema relativo à escolha da norma por parte do advogado. Os debates que abrangem o juízo de fato pelo órgão julgador serão tratados adiante. Porém, alguns pontos que lá serão usados devem ser aqui antecipados, já que tanto aquele processo decisório quanto a atribuição pela parte de relevância a um acontecimento apresentam algumas semelhanças.

O advogado, num primeiro momento, recebe por meio de relatos do cliente um cenário de acontecimentos no qual se originou uma insatisfação. Estes fatos narrados são interpretados pelo operador do direito e, a partir daí, surge um enquadramento legal provisório, fruto de uma análise superficial do que lhe fora apresentado. Após essa recepção, o defensor técnico irá analisar o caso com mais profundidade, fará um estudo

\footnotetext{
201 Tais observações são feitas por TARUFFO, La prueba de los hechos, cit., p. 93,

${ }^{202}$ Não cabe aqui elencar os artigos de diversos códigos estrangeiros. Tal atividade, além de repetitiva e enfadonha, não traria qualquer benefício ao trabalho. Contudo, apenas para que se faça menção a comentários doutrinários sobre a exigência do chamado fundamento jurídico no ato introdutório, ver: KAMINKER, Reflexiones sobre hechos, cit., p. 131, na Argentina; TARUFFO, Elementi per um'analisi, cit. pp. 237 e ss., na Itália; PICO I JunOY, Modificación de la demanda, cit. p. 25, na Espanha; JoLOWICZ, The parties, the judge and the facts of the case, in Studi in Onore di Vottorio Denti, v. II, Padova, 1994, pp. 233 e ss. para dados de França e Inglaterra.
} 
mais atento dos documentos, realizará pesquisas jurisprudenciais a fim averiguar se a tese traçada prospera nos tribunais ou se está fada ao fracasso devido à solidificação de um entendimento contrário. Feito isso, aquela primeira sugestão de enquadramento normativo pode se manter ou, em situações adversas, alterar-se para outro que se entende mais pertinente. $^{203}$

Definida a norma que será invocada como suporte da pretensão do autor, o advogado volta ao cenário fático e, a partir daí, os seleciona de acordo com a fattispecie ali prevista. Recorta a realidade (construção seletiva) a ponto de excluir aquilo que não favorece a sua tese e exalta os acontecimentos que dão suporte ao que está sendo defendido $^{204}$. A diferença entre essa seleção de fatos e aquela realizada pelo juiz está na posição epistemológica de ambos: no primeiro caso há um envolvimento no qual o advogado não seleciona a norma que entende correta, tampouco os fatos que são verdadeiros buscando-se com eles uma completude do cenário factual. Ao contrário, suas escolhas se baseiam em um interesse e estão previamente direcionadas a sustentar a pretensão de seu cliente, dando à peça inicial o caráter já apontado de incompletude e parcialidade $^{205}$. O julgador, entretanto, por sua posição de destaque, faz a construção das premissas maior e menor de maneira imparcial, baseando-se em um cenário fático verdadeiro e em uma correta aplicação da lei.

O mesmo autor realiza, outrossim, construções seletivas de enunciados fáticos relativos a acontecimentos secundários, isto é, que não se encontram na fattispecie legal, mas que são logicamente relevantes para que se possa aferir a veracidade de um fato tido como principal. Mais uma vez é de se notar que o enquadramento desses acontecimentos como sendo secundários, ou logicamente importantes, é fruto de um processo complexo de

\footnotetext{
${ }^{203}$ Nem todas as demandas surgem dessa maneira, vale aqui ressaltar. Existem aquelas nas quais uma tese jurídica é consolidada por um tribunal, tese essa que abrange as circunstâncias fáticas vividas por inúmeras pessoas. Nessa espécie de demanda, inverte-se a ordem dos fatores: primeiro vem a tese, depois as pessoas, baseando-se nela, analisam se sua condição enquadra-se ali. Citam-se como exemplos dessas ações aquelas relacionadas ao Plano Collor, ao Plano Verão, ao recálculo do benefício da sexta-parte e do adicional por tempo de serviço, dentre tantas outras.

${ }^{204}$ Retratando o que aqui se disse e fazendo referência a uma atividade transcendente do advogado, ver KAMINKER, Reflexiones sobre hechos, cit., p. 130-131. Referindo-se à parcialidade da escolha da norma, GAMBA, Diritto societario, cit. pp. 404, 411.

${ }^{205}$ Sobre o ponto é possível destacar situações interessantes. A vida prática do foro demonstra que em alguns casos os advogados, não obstante a pouca aceitação de sua tese por parte da jurisprudência, buscam julgados, ainda que raros, dos mais variados tribunais como recurso argumentativo de sua peça, buscando dar sustentabilidade ao que ali se defende. Ainda que equivocado o enquadramento do fato à norma, o interesse $\mathrm{e}$ parcialidade se sobressaem e a subsunção forçada é mantida.
} 
escolhas por parte dos advogados do autor sempre permeados pelas posições epistemológicas de parcialidade e interesse.

Pode-se imaginar, outrossim, como já dito, além dos acontecimentos principais e secundários, fatos que são objeto de descrição, mas que não apresentam de início qualquer relevância para a solução do caso, quer jurídica quer logicamente. Em outros termos, são enunciados sobre fatos que compõem o conjunto narrativo da inicial, mas que não integram acontecimentos constitutivos ou indiciários, não desempenhando nenhum papel no que tange à prova e ao convencimento do órgão julgador segundo a linha traçada pelo operador do direito. Contudo, mesmo não se enquadrando às categorias geralmente destacadas pela doutrina clássica, os fatos irrelevantes, aos olhos de quem escreve, devem ser levados em consideração para a solução do caso, pois compõem o conjunto histórico da insatisfação e, portanto, não devem ser excluídos das análises.

Ademais, é de se notar que o mesmo processo de construção seletiva é realizado pelo réu ${ }^{206}$. Ele, em posição defensiva, formula enunciados fáticos principais, secundários e irrelevantes. Porém, a relevância dos fenômenos é, dessa vez, direcionados a barrar a tese contida na inicial, sustentar uma tese de defesa ou mesmo apoiar uma pretensão reconvencional. Independentemente da estratégia por ele adotada, as mesmas observações feitas acima quanto ao autor servem para o réu: os enquadramentos fatos/normas são hipotéticos, não passando de sugestões, além de serem parciais, incompletos e potencialmente provisórios. ${ }^{207}$

Destaca-se, igualmente, que a formulação de enunciados se dá em um contexto dialético. Logo, a hipótese inicial proposta pelas partes pode, de acordo com a contraposta proposição, necessitar de alterações e ajustes. Tais observações valem, inclusive, para a norma escolhida pelos narradores, influindo também na posição de importância dada a um fato.

Somado a isso, vale lembrar que as atividades das partes são influenciadas igualmente pela atividade do juiz, que pode relevar de ofício (sempre promovendo o contraditório entre os sujeitos processuais) fatos principais (exceções) ou secundários, indicar às partes conclusões que podem ser tiradas sobre fatos constitutivos a partir dos

\footnotetext{
${ }^{206}$ Todos os outros processos de construção são realizados tanto pelo réu como pelo autor. Para o presente tópico da dissertação, o seletivo é o que importa pelo critério de relevância dos fatos.

207 Nesse mesmo sentido, GAMBA, Diritto societario, cit. pp. 405-406, 411 e ss.; ID., Domande senza risposta, cit., pp. 176 e ss.; TARUFFO, Elementi per um'analisi, cit., pp. 242 e ss..
} 
fatos indiciários ${ }^{208}$, bem como apontar para fatos irrelevantes que são potencialmente enquadráveis em outra categoria de importância ante a possibilidade de um reenquadramento normativo. ${ }^{209}$

Os temas e debates relativos à obrigatoriedade e vinculação do juiz aos fundamentos jurídicos da demanda serão objeto de análise em sede específica e futura. Para o momento, basta apontar que o princípio iuria novit curia vige mesmo em sistemas tidos como liberais e defensores ferrenhos do princípio dispositivo ${ }^{210}$, autorizando o juiz a reenquadrar os fatos em uma nova norma e, assim, alterar o suporte fático proposto e a relevância factual dentro do processo. ${ }^{211}$

Como se vê, não há aqui como vincular a possibilidade de modificação dos fatos ao critério de relevância, salvo, evidentemente, se se parte de uma premissa simplificada e estática da estrutura processual, típica de uma visão silogística da aplicação do direito ${ }^{212}$. O

${ }^{208}$ Ibidem, p. 406. Para maiores aprofundamentos quanto à possibilidade de o juiz relevar de ofício alguns fatos, ver: ID., L'integrazione dell'art. 101 C.P.C., il contraddittorio sulle questioni rilevate d'ufficio e la 'scommessa aperta' dell'ordinamento processuale, in TARUFFO (diretto da), Il processo riformato, Bologna, 2010, pp. 65-179, em especial pp. 71-87; CHIARLONI, Questioni rilevabili d'ufficio, diritto di difesa e 'formalismo delle garanzie', in Riv. trim. dir. proc. civ., 1987, p. 569 e ss.; CivinINI, Poteri del giudice e delle parti, cit., pp. 1 e ss.; CORSINI, Rilevabilità di ufficio della nullità contrattuale, principio della domanda e poteri del giudice, in Riv. dir. civ., 2004, pp. 667 e ss.; DENTI, Questioni rilevabili d'ufficio e contraddittorio, in Riv. dir. proc., 1968, pp. 217 e ss.; GRASSO, La pronuncia d'ufficio, Milano, 1967, pp. 43 e ss.; LuISO, Questione rilevata di ufficio e contraddittorio: uma sentenza 'rivoluzionaria'?, in Giust. civ., 2002, pp. 1612-1615.

209 Nesse mesmo sentido, fazendo referência à norma como diretriz de relevância e destacando que a alteração desse critério normativo altera, outrossim, a importância dos enunciados dentro da colheita da prova, em específico da testemunha, ver JeROME FrAnk, Law and the Modern Mind, Nova York., 1930, p. 116.

${ }^{210}$ Como exemplo e por todos, Berzosa Francos, Demanda, 'causa petendi' y objeto del proceso, Salamanca, 1984, pp. 47-53. Para aprofundamentos sobre a dinâmica do processo e a alteração da relevância durante seu curso, com ilustrativa comparação do processo com o jogo de xadrez, CSABA VARGA, The Noncognitive Character of the Judicial Establishment of Facts, in Legal System and Practical Reason, n. 15. Stutgart, 1991, ed. Hans-Joachim Koch \& Ulfrid Neumann (Stuttgart: Franz Steiner Verlag Stuttgart 1994), pp. 230-239.

211 Expressamente nesse sentido, DINAMARCO, Instituições, II, cit., p. 132. No mesmo sentido, mas justificando a possibilidade de modificação da qualificação jurídica em uma possível adoção pelo CPC da teoria da substanciação, ver: CinTra, Dinamarco e Grinover, Teoria Geral do Processo, São Paulo, 2000. pp. 260-261. Quanto à modificação do nomen juris dos fatos alegados pelas partes, FERRI, Stuttura del processo, cit. p. 89.

${ }^{212}$ São expressivas as palavras de TARUFFO sobre a definição da relevância do fato no âmbito do processo, que aqui se encaixam perfeitamente: "È infatti nel rapporto dinamico tra norma e fatto, che si instaura concretamente in funzione della decisione sul caso concreto, che avviene la determinazione del fatto giuridicamente rilevante. Ciò implica che tale determinazione sia il risultato di attività interpretative ed ermeneutiche complesse, e di una concatenazione di giudizi e di valutazioni: la 'costruzione del caso' procede per gradi, e l'individuazione delle premesse di fatto e di diritto della decisione non è che il momento finale di un procedimento articolato in vari momenti”, Prova (in generale), cit. p. 9; ID., La prueba de los hechos, cit. p. 124. Na mesma obra, apontando para situações em que heuristicamente há dificuldades para se definir se um fato é secundário ou principal, o autor corrobora a tese de que a relevância do fato não é algo 
processo possui como característica intrínseca a dinamicidade, característica essa que reflete diretamente na importância dos enunciados fáticos formulados pelas partes. ${ }^{213}$

Ademais, e entrando nesse momento no segundo nó problemático do tema da relevância, a afirmação de que a divisão entre fato principal (constitutivo, jurídico etc.) e secundário (indiciário, simples...) se dá de acordo com a fattispecie normativa não soluciona o problema como um todo, conforme já apontado. Ao contrário, traz com ela novas dificuldades, tais como a necessidade de identificação do suporte fático normativo e da forma de delimitação da abstrakte Tatbestand pelas normas. Ocorre, porém, que uma rápida análise do sistema positivo brasileiro é suficiente para concluir que, em absoluto, não é clara a maneira como as normas individualizam os fatos que elas próprias qualificam como jurídicos e, conseqüentemente, relevantes. ${ }^{214}$

estático, simples e determinado a priori. Com a sensibilidade que lhe é peculiar, questiona-se se o evento que constitui o início e o fim dos vinte anos de posse são fatos principais ou secundários, uma vez que somente logicamente conseguem apontar para uma duração intermediária do evento. Ao final, conclui que as classes principais e secundárias somente são aplicáveis aos fatos simples, apresentando inúmeras complicações em se tratando de fato complexo. Nesse sentido, ver pp. 127-128. No mesmo sentido, JolowiCZ, The parties, cit. pp. 236-237.

${ }^{213}$ Nesse sentido, a qualificação principal-secundário-irrelevante pode ser alterada ao longo do processo. É de se notar que inclusive os fatos irrelevantes, que tinham grau zero de importância no ato parcial introdutório (e também parcial defensivo), compõem uma categoria móvel, isto é, dinâmica. Cabe destacar aqui que algumas circunstâncias que inicialmente são tidas como desimportantes nas manifestações iniciais das partes somente o são por uma simples razão: os narradores as consideram pressupostos óbvios e as assumem como base normal dos fatos. Tais circunstâncias, em outras palavras, são tidas como background do acontecimento. Nesse sentido, por exemplo, todo fato narrado pelas partes tem em si uma temperatura e uma pressão que, se não forem objetos de enunciados, serão consideradas 'normais' e irrelevantes para o caso. Ocorre, porém, que eventuais anormalidades nesses elementos circunstanciais podem ser desconhecidas por parte do narrador, mas fundamentais para a solução da crise se descobertas. Basta colocá-las em debate para que mudem de categoria de importância. Em uma situação hipotética processual, pode-se pensar em uma perícia que detecte uma pressão elevada ou diminuta, uma temperatura destoante daquela que seria razoável (ideal), enfim, circunstâncias que poderiam influenciar diretamente a decisão e preencher por completo a fattispecie normativa. Nesse caso, de irrelevante (background fático), o acontecimento passa a ser principal. Nesse mesmo sentido, com aprofundamentos, TARUFFO, La prueba de los hechos, pp. 126-127. Entretanto, reconhece-se que essa visão não é pacífica. Em sentido contrário, GIAN FRANCO RICCI, Questioni controverse, passim. Para este autor, que possui raciocínio parecido com o de grande parte da doutrina, "le parti possono provare solo i fatti da esse allegati. Non è amessa prova su fatti non allegati, ancorchè risultanti per altre vie dagli atti del procedimento (ad. es. per effetto della testimonianza di um terzo)", p. 323. Para ele, que desconsidera as características epistemológicas aqui destacadas, "La questione è delicata, ma non incrina certo l'onere delle allegazioni. Per esempio, se un teste riferisce che il credito invocato dall' attore è stato già pagato mentre il convenuto si è limitato a dire che esso si è prescritto, il giudice, ancorchè convinto della veridicità dell'affermazione del teste, non potrebbe respingere la domanda per intervenuto pagamento. Infatti, pur se l'intervenuto pagamento costituice circostanza rilevabile d'ufficio dal giudice, il suo potere incontra un limite nella mancata allegazione del fatto ad opera della parte", p. 324. Igualmente, em análise do direito espanhol, SANCHIS CRESPO, Aproximación a la prueba en el nuevo proceso civil español, in Rev. Peruana de Derecho Procesal, jun/2002, p. 271.

214 Apontando tal problema, TARUFFO, La prueba de los hechos, p. 105; no mesmo sentido, apontando para dificuldade de identificação, por motivos diversos dos aqui expostos, IRTI, La crisi della fattispecie, in Rev. dir. proc., 2014, II, pp. 36 e ss.. 
Parte da doutrina, ao analisar o problema, indica que os enunciados normativos possuem um aspecto descritivo, também chamado de frástico, e outro que o qualifica juridicamente, atribuindo ao fato ali descrito conseqüências jurídicas. Segundo TARUFFO, para essa fração doutrinária “se trataría de un hecho 'histórico' o 'bruto' que la norma selecciona en el momento en que le atribuye relevancia jurídica; ese hecho representaría la prótasis de la norma, es decir, aquello que debe probarse para que sea posible aplicar justamente la norma al caso". 215

Haveria, então, uma descrição de um determinado acontecimento (conceitos frásticos) e sua qualificação jurídica (conceitos qualificativos), seguidas de uma imposição de conseqüência.

O esquema traçado por essa linha doutrinária e descrito acima parece, em um primeiro momento, claro e satisfatório. Contudo, se analisado de forma mais profunda, revela inúmeras dificuldades que devem ser aqui brevemente encaradas.

Tal como fora dito anteriormente para as construções das narrações pelas partes, nas leis, o fato não é dado como um acontecimento naturalístico, isto é, como um dado empírico perceptível pelos sentidos humanos ou um evento do plano fenomênico. Ao contrário, tal como ocorre com a petição inicial, por exemplo, os fatos em uma dada norma são apenas objetos de descrições, de enunciações, e, portanto, não são objetiva e rigidamente determinados, nem tampouco um dado em absoluto, mas sim fruto de construções lingüísticas e conceituais ${ }^{216}$, o que põe em xeque o conceito descritivo tal como posto.

Quanto a isso, inclusive, cabem aqui algumas considerações de ordem crítica. O fato de a doutrina não avançar na análise sobre o suporte fático normativo, estacionando o raciocínio no tracejar de uma estrutura abstrata da norma (suporte fático/ qualificação jurídica/ conseqüência jurídica), segundo quem escreve, é fator de incertezas e confusões.

A simplificação descrita causa a impressão aos operadores do direito de que a norma apresentará sempre uma estrutura assim definida: "se acontece $X$, está-se diante de $\mathrm{Y}$ e, então, a conseqüência $\mathrm{Z}$ deve ser observada", no qual X é um acontecimento - um

215 Ibidem, p. 106. Para aprofundamentos sobre conceitos frásticos e conceitos qualificatórios, ver SCARPELLI, Contributo alla semantica del linguaggio normativo, Milano, 1985, p. 123 e ss, apud TARUFFO, Ibidem.

${ }^{216}$ Idem, Ibidem. 
dado empírico-, Y é uma qualificação jurídica - uma definição do fato como instituto do direito - e Z uma consequiência prevista a este acontecimento. ${ }^{217}$

Ocorre, todavia, que ao se deparar com as circunstâncias da prática jurídica em um cenário processual, o operador constata, por primeiro, que nem os fatos são simples como idealizados (e como foi visto em momento precedente desse trabalho), nem a norma, muitas vezes, o descreve de maneira clara e objetiva. Com essa incompatibilidade, surgem dificuldades na atividade de subsunção fato/norma e nascem as inseguranças conhecidas.

Ademais, tal como já discorrido, a definição de um determinado fato só se dá dentro de um determinado contexto, isto é, sua definição é culture-laden ou value-laden ${ }^{218}$. Desse modo, estando o enunciado contido em uma norma, deve sua definição, necessariamente, ser dada em um contexto legal ou jurídico. Entretanto, embora verdadeiras, essas afirmações não resolvem o problema como um todo, além de induzir a conclusões precipitadas. Baseando-se no fato de que é o contexto normativo que determina o fato, parte da doutrina defende que o suporte fático é dado somente se analisado nesse contexto. A correta definição do suposto fático, pois, se daria somente por meio das categorias jurídicas pela norma descritas.

Retirando do ordenamento um exemplo aleatório dentre tantos possíveis, vê-se que em alguns casos é exatamente isso que ocorre. O instituto da coação, regrado pelo art. 151 do Código Civil, não traz, como se nota de sua redação, descrições de fatos 'brutos', entendidos como dados empíricos, mas, ao contrário disso, estrutura um instituto no qual fatos podem ser enquadrados. Devido a isso, parte da doutrina crê que a dimensão concreta dos acontecimentos não importa para a definição dos limites do suporte fático ${ }^{219}$, mas, ao contrário disso, são os contornos jurídicos abertos do instituto que definiriam a fattispecie.

A parte os pontos negativos e positivos dessas interpretações doutrinárias acima descritas, fato é que elas não são suficientes para resolver o problema da identificação da

\footnotetext{
${ }^{217}$ Há de se notar, inclusive, que a simplificação estrutural apontada induz e suscita debates vinculados à identificação da demanda que, como se viu, não prosperam. Uns, segundo se constatou, dizem que a causa de pedir tem como elemento tão somente a qualificação jurídica dos fatos dada pela norma invocada. Outros, por outro lado, afirmam que os fatos como dados empíricos é que devem prevalecer como elemento identificador. Ocorre, todavia, que a fattispecie normativa é construída por enunciados que deverão ser interpretados, conforme se verá adiante, não sendo algo clara e objetivamente definida.

${ }^{218}$ PUTMAM, Razón, verdad y historia, cit., pp. 132

219 As mesmas considerações feitas na nota 79 retro servem para o momento do raciocínio. A interpretação radical de que os dados empíricos pouco importam para a identificação da protesis normativa acarreta erros de perspectiva e influencia a criação de teorias muitas vezes descoladas da realidade processual.
} 
abstrakte Tatbestand e, conseqüentemente, da individuação dos fatos relevantes no cenário processual. Há, como é facilmente encontrável, normas em que o fato ou conduta não se individualiza em face de institutos jurídicos, mas sim em descrições de eventos abstratamente previstos. $^{220}$

Quanto ao ponto, destaca-se, por primeiro, que o problema parece não residir no plano ontológico, isto é, não se refere à existência material ou não dos acontecimentos. Ao contrário disso, ao que parece, o nó da questão está no plano semântico, já que o que se busca é a individualização dos significados das normas. É sobre a linguagem contida no enunciado normativo e sua estrutura que se encontra a possibilidade de individualizar os fatos 'puros' ou a necessidade de recorrer aos institutos (categorias) jurídicos ${ }^{221}$. A identificação do suporte fático é, pois, fruto de um processo interpretativo.

Transportar o problema de um plano (ontológico) para outro (semântico), todavia, traz consigo alguns novos problemas. Afirmar que a individualização da fattispecie é fruto de interpretação não é uma solução satisfatória, não obstante arraste o problema pro âmbito correto do debate. Parece, isso sim, relegar esses problemas à casuística, motivo pelo qual se deve aqui traçar algumas observações, ainda que superficiais, para aclarar o raciocínio.

O primeiro problema dessa transposição a ser enfrentado - considerando que agora o operador do direito deverá interpretar o que seria o fato normativo - diz respeito à vagueza da linguagem utilizada em geral pelas normas e em específico pela parte normativa destinada a individualizar a fattispecie. Seria recomendável, ou mesmo ideal, se as normas fossem redigidas com um linguajar claro e preciso, definindo objetivamente o suporte fático normativo. Deixando de lado a impossibilidade concreta de uma precisão absoluta $^{222}$, as normas, geralmente, vêm expressadas por meio de termos vagos e

\footnotetext{
${ }^{220}$ No âmbito penal, essa é a regra, pois os tipos descrevem condutas e comportamentos dos indivíduos tidos como antijurídicos. Matar alguém, subtrair coisa alheia móvel, dentre tantos outros são acontecimentos que se individualizam independentemente de conceitos do direito. Na esfera cível, por seu turno, pode-se tomar como exemplo o art. $2^{\circ}$ do Código Civil, no qual se prevê que "a personalidade civil da pessoa começa do nascimento com vida (...)".

${ }^{221}$ Todas essas observações são de TARUFFO, La prueba, cit. pp. 107-108. Para aprofundamentos e definições relativos ao significado hilético (material) e o significado interpretativo das normas, ver: WRÓBLEWSKI, Legal language and legal interpretation, in Law and Philosophy, n. 4, 1985, pp. 240-241.

${ }^{222}$ KAUFMAnN, Diritto e linguaggio, cit., p. 184 e ss; remissão à nota 40. Nesse mesmo sentido, JEROME FRANK, What Courts Do in Fact, in Illinois Law Review 26, I, 1932, p. 645.
} 
genéricos. Essa vagueza, como é intuitivo, depende da linguagem adotada pelo legislador. $^{223}$

Destarte, a identificação dos fatos individualizados na abstrakte Tatbestand depende, em primeiro lugar, de uma redução da vagueza normativa, redução essa que será mais simples se a linguagem for simples, clara e determinada, e mais complexa se a linguagem adotada for obscura, aberta, variável e complicada. Em outras palavras, individuar o suporte fático normativo é fruto de um processo interpretativo, que terá menores oscilações quando a vagueza dos termos for pequena, dando menor azo à interpretações discricionárias. ${ }^{224}$

A segunda ordem de problemas ao ser transpor a identificação da fattispecie do plano ontológico para o interpretativo se encontra no fato de que não há uma distinção clara entre uma linguagem ordinária e uma linguagem jurídica. É possível perceber em um rápido olhar para o ordenamento que, muitas vezes, o legislador insere na norma termos e expressões pertencentes ao linguajar comum, abdicando do uso de expressões jurídicas para aquele mesmo objeto. Em outros termos, usa-se na redação da regra um termo atécnico para descrever algo que possui um termo institucional-jurídico. Segundo TARUFFO, isso ocorre principalmente no que tange ao suposto fático, tratando-se de um dado histórico e culturalmente contingente, relacionado muitas vezes com a menor difusão de termo técnico-jurídico do que aquele usado na comunicação cotidiana, o qual tem seu sentido muito mais claro e objetivo ${ }^{225}$. Ademais, em especial no que tange ao Brasil, o legislador, em muitos casos, não possui formação técnica a ponto de conhecer o termo

\footnotetext{
${ }^{223}$ TARUFFO, com a clareza que lhe é peculiar, assim exemplifica: "resulta intuitivo que una norma que hable de 'automóviles' es más especifica y menos vaga que una norma que hable de 'vehículos', pero - más allá del hecho de que obviamente tienen distintos campos de aplicación - ambas normas siguem siendo (en distintos grados) vagas (quedando, por ejemplo, por determinar si, y en qué casos, una ambulancia es un automóvil y si, y en qué casos, un cochecito para niños es um vehículo", La prueba de los hechos, cit., pp. 108-109.

224 Tratando da vagueza normativa e a função interpretativa do juiz, CINZIA GAMBA assim se expressa: "Pertanto, in seede di applicazione, all'elevato grado di vaghezza che caratterizza la fattispecie normativa corrisponde um proporzionale ampiamento dei poteri del giudice: si afferma che il legislatore, ricorrendo agli standards, delega la competenza dell'individualizzazione del caso concreto all'organo che è chiamato ad applicare il diritto", Diritto societario, cit. p 422. O raciocínio é perfeitamente aplicável à formulação das narrações pelos advogados das partes: quanto maior à vagueza normativa, maior será a atividade interpretativa do operador do direito, sendo também maior à variabilidade com que uma mesma crise seja exposta em juízo.

${ }^{225}$ TARUFFO, La prueba de los hechos, cit., pp. 109-110. Para WRÓBLEWSKI, destaca-se, a "legal language is treated as a sub-type of natural language. It shares with natural languange several relevant semantic and pragmatic features, such as fuzziness, contextuality of meaning and viability as an instrument of communication”, Legal Language, cit., p. 240.
} 
jurídico para aquele determinado objeto de descrição, ou seja, ele ignora a acepção institucional do fato, adotando em seus projetos legislativos a linguagem habitual. $\mathrm{O}$ termo vulgar, pois, deverá ser tomado pela ótica jurídica.

Quanto ao ponto, porém, deve-se ressaltar que dificilmente uma expressão comum, ao entrar no contexto normativo, manterá seu significado originário puro - ou, mais especificamente, extrajurídico ${ }^{226}$. Freqüentemente ela irá assumir um significado contextual jurídico ainda que diferente do termo ideal (técnico) para a definição daquilo que se quer descrever.

Aliás, sobre isso, imprescindível aqui a abertura de parênteses para deixar claro o seguinte: ao se referir à linguagem comum e à linguagem jurídica não se está, em absoluto, adotando a idéia de que o direito possa ser constituído por um linguajar autônomo, independente da linguagem comum. Seria fora de propósito afirmar que esta prescinde daquele $^{227}$. Tampouco se está afirmando que o significado jurídico de um termo não possui nenhuma relação com o significado adotado na linguagem vulgar. $\mathrm{O}$ que se quer fazer compreender é que o transladar de uma expressão de um contexto para o outro altera em maior ou menor medida o seu significado original, o que é relevante quando se trata de interpretação.

Feita essa ressalva, e prosseguindo com o raciocínio, há também a possibilidade de um mesmo termo ter dois significados, um jurídico e um 'vulgar'. Diferentemente da situação precedente, em que se tratava de dois termos para definir um único objeto, aqui se tem dois objetos definidos por apenas um termo. A expressão "parente", por exemplo, é freqüentemente usada no dia a dia com um sentido extremamente amplo, ao passo que no Código Civil é empregada com significação técnica e restrita. O sentido que se deve adotar, pois, é sempre o técnico, podendo-se utilizar das acepções comuns (pouco freqüientes, frise-se) somente quando inexistir uma significação jurídica. ${ }^{228}$

${ }^{226}$ Idem, ibidem.

227 Para maiores aprofundamentos, por todos, com ampla bibliografia: LAZZARO, Diritto e linguaggio comune, in Riv. trim. proc. civ., 1981, p. 140.

228 As duas situações, entretanto, podem ser manipuladas pelas partes no sentido de sustentar a tese defendida. Por suas posições de envolvimento, podem construir seus enunciados atribuindo aos suportes fáticos normativos conteúdos comuns quando o ideal seria interpretá-los tecnicamente. Ademais, podem as partes atribuir sentidos vulgares às normas e esconder as acepções jurídicas existentes. Se algum impacto positivo essas construções terão somente a casuística irá dizer. Entretanto, em busca da vitória no processo, independentemente da justiça da decisão, a fattispecie normativa poderá ser preenchida com os mais variados significados. Pode-se pensar, outrossim, em uma situação que não é incomum no quotidiano forense: 
Importante destacar, entretanto, que, embora as observações acima sugiram um parâmetro mínimo de interpretação e pontue fatores importantes da estrutura da norma, elas não são suficientes para solucionar os problemas propostos. As significações de termos, se absoluta ou jurídica, dependerá da relação contingente existente em um determinado local e tempo, bem como em uma determinada cultura jurídica, entre linguagem jurídica e linguagem comum ${ }^{229}$, o que aponta para uma variabilidade grande quanto à definição correta e definitiva da fattispecie normativa, bem como, conseqüentemente, da definição dos fatos tidos por constitutivos e secundários.

Crê-se, ademais, ser importante relevar um último aspecto quanto ao suporte fático normativo. Embora pareça evidente e diretamente dedutível das observações anteriormente traçadas, é fundamental destacar que ao falar do suporte fático normativo não se está fazendo referência tão só ao fato em seu estado 'puro', 'bruto', objetivamente definido. Ao contrário, também ao usar linguajar jurídico, trazendo à sua base 'fatos jurídicos' (entendidos como aqueles que necessitam de conceitos jurídicos para definição de seu significado), faz-se menção a fatos, a "ocurrencias del mundo extrajurídico cuya verificación es, en todo caso, condición para la aplicación de la norma al caso concreto". 230

Tal questão é importante para o objeto do trabalho devido ao fato de que, como visto, parte da doutrina crê que a modificação fática pode dar-se somente quanto aos acontecimentos puros, mas não quanto à sua relação jurídica (teoria da individuação). Contudo, ao que parece, a abordagem é dada pela perspectiva ontológica, ainda que inconscientemente. Como se viu, em algumas situações, parece bastante difícil identificar o limite entre o que seria um fato puro e um fato jurídico, principalmente se a temática for abordada pela perspectiva semântica, que parece ser a mais correta. Como se procurou mostrar, uma descrição fática dificilmente terá como objeto um fato 'puro' (ou com

advogados, por alguma deficiência técnica de compreensão, fazem interpretações equivocadas das normas e seus suportes de fato, atribuindo a eles significações que não condizem com o conteúdo jurídico idealizado. Consciente ou inconscientemente, a individualização da fattispecie é variável e pode ser alterada no curso processual pelos sujeitos atuantes.

${ }^{229}$ TARUFFO, La prueba de los hechos, cit. p. 111.

${ }^{230}$ Idem, ibidem. Em continuação, aclarando o que aqui se pretende fazer entender, TARUFFO exemplifica: "que el daño sea un concepto jurídico no excluye que determinadas circunstancias deban ser verificadas para que alguien tenga derecho al ressarcimiento; del mismo modo, se puede sostener que no detenerse ante una señal de 'stop' es un hecho law-laden, pero esto no impide que lo que se castiga sea um comportamiento material. La mayoría de edad es un estatus jurídico, pero éste existe únicamente respecto de aquellos que nacieron antes de una determinada fecha”. 
significado definido somente pela linguagem habitual). Por outro lado, os fatos jurídicos não possuem significação autônoma, desvinculada daquele 'sentido vulgar'. Isso dificulta, pois, a aplicação desses critérios para delimitar até que ponto a atividade modificativa pode ou não ser exercida.

Como se nota, a individuação da abstrakte Tatbestand, se tomada pela ótica simplificativa tradicional, parece ser facilmente individualizável. Porém, ao ser utilizada em situações concretas, aquela visão parece ter sua utilidade bastante reduzida. Por outro lado, se a atividade identificativa da fattispecie depende de métodos interpretativos, que parecem ser ideais para o enfrentamento da questão, então a conclusão lógica é que há uma potencial variabilidade também naquilo que concerne ao fato apontado pela norma como sendo pressuposto para sua aplicação.

Destarte, trançando-se uma síntese do que foi exposto e estruturando uma pequena conclusão do tópico, vê-se que a importância do fato dado pelo autor em sua inicial, bem como a relevância fática atribuída pelo réu em sua contestação, é apenas sugestiva e possui caráter provisório, pois: a) a escolha normativa pelas partes (e, então, os fatos principais de acordo com a fattispecie da norma) é feita partindo-se de uma posição epistemológica parcial e interessada, ao passo que o juiz, livre para alterar a norma segundo o princípio iuria novit curia, 'escolhe' a regra aplicável segundo posições epistemológicas de destacamento $^{231}$; b) o cenário dialético processual exige, muitas vezes, uma mudança de comportamento dos sujeitos processuais, induzindo-os a alterar o critério de relevância inicialmente proposto ${ }^{232}$; e c) a individuação do suporte fático normativo não é algo objetivo, simples e unitário, tal como se concluiu por uma análise ontológica, mas sim apresenta critérios de determinação extremamente variáveis, fruto da interpretação dos agentes do processo, o que afasta o caráter rígido de sua individuação. ${ }^{233}$

Logo, encarar a demanda como algo determinado e claro desde a primeira manifestação das partes, dando a ela um caráter estático, parece, mais uma vez, ao menos

${ }^{231}$ Expressamente quanto ao caráter provisório da importância dos fatos no processo em um cenário de prova, TARUFFO afirma: "Va peraltro sottolineato che tutte queste qualificazioni sono relative, nel caso concreto, ala determinazione del contesto di decisione e dalla fattispecie normativa che viene impiegata come criterio giuridico di qualificazione dei fatti: qualunque variazione a questo proposito, o l'adozione di schemi di decisione diversi (ad es. a seconda che si tratti dell'autore, del convenuto o del giudice), implica mutamenti nel contesto di decisione, e quindi variazioni relative a ciò che realmente può costituire oggetto di prova nel singolo caso", Prova (in generale), cit. pp. 9-10.

${ }^{232}$ Vide nota 89 , no qual um fato irrelevante se torna principal.

233 Ibidem, p. 113. 
segundo o que se viu, um equívoco que acarreta mais problemas que benefícios. No que tange ao objeto de estudo, condicionar a modificação da demanda à relevância ou à irrelevância atribuída pelas partes aos fatos em suas manifestações iniciais pode não só não solucionar as questões mais difíceis - como parece ser o caso quando se analisa a doutrina clássica-, mas também portar inúmeros novos imbróglios oriundos de uma perspectiva equivocada. Essa visão, como é de fácil percepção, funda-se em uma interpretação da causa de pedir - quer remota quer próxima - fundamentalmente processual, descolada da real natureza das narrações processuais e ignora as nuances epistemológicas importantes que aqui se tem buscado apontar.

Desse modo, o instituto modificativo não pode e não deve ser atrelado aos chamados fatos secundários, sendo vedada sua aplicação ao chamado fato constitutivo do direito do autor (ou, como preferem alguns, principal, jurídico etc.). A dinamicidade com que os fatos transitam dentro das categorias acima descritas, da inicial à sentença, torna difícil - senão impossível - delimitar o que pode ou não ser modificado ao longo do curso do processo.

Ademais, ressalta-se que a possibilidade de modificação da relevância por parte dos sujeitos parciais do processo, pode favorecer uma maior compreensão da crise por parte dos interlocutores responsáveis pela decisão do caso, isto é, os juízes, contribuindo para que eles possam tomar ciência dos reais limites da insatisfação sobre a qual devem se manifestar, dando à sentença uma maior qualidade e, conseqüentemente, solucionando a crise com maior justiça.

Em relação ao fenômeno da indiferença quanto à realidade fática pelos julgadores e seu impacto na justiça da decisão, maiores considerações serão traçadas adiante em tópico próprio. Entretanto, é intuitivo concluir que o abandono de fatos que ganham relevância no curso do processo, isto é, que saem de uma categoria e entram em outra, quer por uma nova interpretação do suporte fático da norma, quer pelo fato de o juiz se utilizar dos poderes advindos da iuria novit curia ou ainda pelas alterações de estratégias comportamentais das partes oriundas do procedimento em contraditório, causa um descolamento da decisão quanto à realidade da crise.

Destarte, a vedação a mudanças de relevância dos fatos por parte dos sujeitos processuais gera, em certos casos, uma decisão descolada do substrato fático da insatisfação e, como conseqüência, uma sentença potencialmente injusta, incapaz de 
resolver o conflito posto diante do Estado-juiz. A modificação pode, ainda que feita no âmbito da importância dos fatos, contribuir para uma sentença com maior qualidade, tema a ser desenvolvido a seguir.

Não bastasse isso, nota-se que relevância dos fatos, diferentemente do que vem sendo dito pela doutrina e jurisprudência, não pode ser o termo de ajuste do instituto da modificação demanda. Ao contrário, assim como todos os enunciados fáticos, por serem parciais, incompletos, fruto de uma construção direcionada dos acontecimentos, a importância dada a alguns acontecimentos objetos das narrações das partes nada mais é do que um indicativo dos limites da crise, não possuindo, desse modo, caráter absoluto e definitivo.

\subsection{Dos enunciados de direito - a escolha da norma na demanda}

O presente tópico do trabalho destina-se a analisar como as normas e institutos jurídicos são apresentados nas manifestações dos sujeitos atuantes no processo. Em outras palavras, buscar-se-á avaliar como os enunciados sobre os acontecimentos da vida - fatos componentes da insatisfação do autor - se revestem com roupagem jurídica apta a sustentar uma pretensão em juízo.

Algumas noções introdutórias sobre as escolhas das normas por parte dos advogados das partes - que, em geral, são os responsáveis técnicos pela formação do ato introdutório - foram traçadas no item anterior destinado à relevância dos fatos. Nesse momento, pois, cabem algumas reflexões mais aprofundadas sobre essas escolhas e os impactos que elas possuem dentro do processo e na resolução da crise apresentada em juízo.

Foi dito no tópico precedente que a apresentação dos fundamentos de direito, requisito do ato introdutório trazido pelo código (art. 282, III), é fruto de um processo de construção e escolhas parciais e interessadas dos defensores das partes. Como fora ali explanado, não podem os advogados simplesmente narrar os acontecimentos do plano fenomênico que originaram a crise de insatisfação de seus clientes. Devem, isso sim, fazer remissões a institutos jurídicos, a normas, a entendimentos interpretativos jurisprudenciais para, só depois, pleitear a tutela que entendem apta, em consonância com a estruturação da 
tese, a atribuir o bem da vida àqueles que os contrataram. Devem os advogados, em outros termos, recobrir suas enunciações fáticas com uma roupagem jurídica.

Importante destacar, ademais, outra observação já feita anteriormente e que possui grande utilidade para o enfrentamento da formação do ato introdutório: os defensores das partes, em regra, recebem de seus clientes relatos dos eventos que geraram a crise para a qual se busca uma solução, relatos estes que deverão ser reproduzidos estrategicamente no capítulo que, em geral, é denominado "dos fatos", além de uma série de documentos, indicação de eventuais testemunhas, bem como outros materiais das mais variadas espécies que comprovariam as narrativas trazidas pelo sujeito insatisfeito.

É de se notar que, normalmente, o advogado, logo após esse primeiro contato com o caso, já possui uma pré-formação de uma possível estrutura jurídica que poderá ser aplicada na defesa daquele que o procurou. O profissional do direito, por sua própria formação técnica e experiência prática forense, consegue, com maior ou menor grau, visualizar possíveis regras do ordenamento posto e eventuais teses de defesa que poderão revestir os acontecimentos componentes da crise. Da mesma forma, poderá já em um primeiro momento concluir se a insatisfação daquele indivíduo não possui qualquer amparo no direito, consubstanciando suas narrações em meros aborrecimentos do dia a dia.

Há casos em que a conclusão sobre o risco da ação exige que o advogado analise o material trazido pelo cliente de maneira mais atenta, tudo a fim de que possa tomar conhecimento mais profundo do que realmente aconteceu, para, só então, possa dar seu parecer sobre o caso. Nessas circunstâncias, é somente em momento sucessivo ao da análise dos documentos que seu grau epistêmico de conhecimento estará maduro para um posicionamento, ou seja, terá aprofundado sua ciência e obtido alguns dados mais precisos quanto à insatisfação ${ }^{234}$. Em relação a esses dois pontos levantados, alguns elementos epistemológicos importantes devem ser destacados.

Em primeiro lugar, nota-se que os advogados, em um momento inicial - e só neste primeiro momento-, agem como desinteressados quanto à sorte do conflito. Para analisar a viabilidade da propositura de uma ação em defesa da pretensão de seu cliente, o profissional do direito deve, ainda que por um pequeno instante, afastar-se dos interesses

\footnotetext{
${ }^{234}$ Maiores aprofundamentos sobre o conceito de grau epistêmico de conhecimento serão traçados adiante. Porém, desde já se atribui a expressão a GärDENFORS, Knowledge in flux: modeling the dynamics of epistemic states, Cambridge, 1988, pp. 9 e ss.
} 
envolvidos a fim de verificar se aquela insatisfação tem ou não amparo no ordenamento. Contudo, tal afastamento é tão somente consultivo e exigido para que ele passe com segurança técnica a situação jurídica ao seu potencial patrocinado ${ }^{235}$. Ainda sim, mesmo que se conclua pela inviabilidade de êxito processual, pode-se, sem qualquer restrição ética, defendê-lo em juízo se assim desejar o indivíduo insatisfeito e estiver de acordo o operador do direito. ${ }^{236}$

Além disso, pode-se extrair do que foi dito que o advogado tem posição epistemológica de leitor não informado (LNI) em relação ao conflito. Ele não teve contato direto com os acontecimentos. Logo, seu conhecimento quanto aos limites da crise se forma baseando-se em relatos feitos por um dos sujeitos envolvidos, isto é, sobre asserções que nada mais são do que frutos de um procedimento interpretativo e de construção da realidade feitos por um indivíduo 'coinvolto', ou seja, sobre narrações feitas baseadas em um ponto de vista interessado e parcial dos eventos. Nesse sentido, as características já abordadas de parcialidade, incompletude e potencial falsidade dos relatos permeiam o material inicial sobre o qual o advogado deverá trabalhar.

Aceito o patrocínio do caso, o advogado passa então a agir direcionadamente, isto é, de forma a defender uma tese que, ao final, traga ao seu cliente o bem da vida desejado e, se possível, dissolva a crise da maneira como ele, sujeito insatisfeito, anseia.

Assim como acontece com os LNIs em geral, os advogados, em momento inicial, somente conseguem identificar no conjunto narrativo trazido pelo potencial cliente

\footnotetext{
${ }^{235}$ Esse momento de afastamento epistemológico do advogado é expressamente previsto pelo Código de Ética e Disciplina da Ordem dos Advogados do Brasil, que em seu art. $8^{\circ}$ dispõe que "o advogado deve informar o cliente, de forma clara e inequívoca, quanto a eventuais riscos da sua pretensão, e das conseqüências que poderão advir da demanda". Nesse mesmo sentido, TED-OAB/SP, Proc. E-2.211/00, Turma de Ética Profissional, Rel. Dr. Carlos Aurélio Mota de Souza, j. 14.09.2000. Para aprofundamentos e comentários sobre esse dever, ver NALINI, Ética Geral e Profissional. São Paulo, 2009, p. 404.

${ }^{236}$ Quanto ao afastamento momentâneo, algumas observações devem ser traçadas. Ainda que haja essa análise neutra da crise, há elementos que fazem com que eles, os advogados, não sejam imparciais na acepção pura do termo (e nem assim devem ser). Os defensores podem ter relações interpessoais privadas com os clientes (amigos, parentes etc.) sem que isso prejudique suas atividades. Ademais, pode-se pensar nos valores envolvidos, em eventual interesse acadêmico pela causa, no desafio da defesa, na confluência ideologia e direito defendido etc.. Há, outrossim, casos expressos em que, mesmo contrários ao direito, um advogado deve atuar em defesa de uma das parte: o direito penal é rico em exemplos. O CPC, por seu turno, em seu art. 302, parágrafo único, prevê a negativa geral como situação típica em que, não obstante o advogado não tenha sido contratado, deve defender um dos litigantes. A parte tudo isso, a própria natureza dessa função exige envolvimento mínimo com o escopo de defesa, que, por si só, tem como presunção um envolvimento parcial e direcionado de seu comportamento. Não obstante todas essas situações e elementos apontados, em regra, há um afastamento epistemológico mínimo que seja em relação ao caso, ainda que por um lapso temporal pequeno.
} 
enunciados de dois tipos, os verossímeis e os falsos sem intenção de serem verdadeiros (que, destaque-se, dificilmente estarão presentes, haja vista os objetivo ilocutórios do narrador e o contexto pré-jurídico em que inseridos). Justamente por essa razão, a estrutura jurídica formulada por eles, advogados, nesse momento não possui caráter definitivo, mas sim apresentam alto grau de variabilidade.

Entretanto, ao analisar o material trazido pelo indivíduo, os defensores farão um juízo de valor sobre os enunciados de fato, podendo identificar dentro do conjunto assertivo alguns enunciados do tipo verdadeiro, bem como poderá concluir pela falsidade de outros. Haverá, outrossim, enunciados sem qualquer amparo ou relação com a documentação aportada, os quais se manterão na categoria dos enunciados verossímeis.

Desse modo, havendo um grau epistemológico de conhecimento mais elevado, isto é, conhecendo mais a fundo os reais limites da insatisfação, os advogados, por meio de seu conhecimento técnico, poderão enquadrar os acontecimentos em institutos jurídicos que lhes pareçam cabíveis e - isso é importante - que favoreçam os interesses de seus clientes. Fundamental notar quanto ao ponto levantado, pois, que os defensores fazem um juízo de fato não buscando a correta roupagem jurídica dos eventos e a justa aplicação da lei. Ao contrário, a análise dos fatos narrados tem como objetivo precípuo a possível sustentação de um enquadramento normativo parcial e interessado.

Feito isso, os patronos buscarão verificar se o enquadramento feito se sustenta ou não na visão dos Tribunais. É comum na prática forense a pesquisa jurisprudencial com intuito de confirmar a viabilidade da tese escolhida. Após esse estudo jurisprudencial, com um cenário de conhecimento mais delimitado e profundo, poderão os advogados, então, retraçar os limites da tese inicialmente estruturada, modificá-la parcialmente, ou então buscarem uma nova montagem jurídica para a defesa de seu cliente. Nos dois últimos casos, o procedimento construtivo de escolhas será reproduzido em sua parcialidade ou integralidade, respectivamente.

Definida a roupagem jurídica dos fatos, subsumidos os enunciados fáticos em institutos do direito e estruturada a tese defensiva dos interesses dos clientes, passam então os patronos a redigir a peça introdutória. Nesse momento, começa todo o procedimento construtivo narrativo descrito anteriormente. Os patronos das partes, com intuito de redigir o ato introdutório da forma mais eficaz a convencer o juiz - segundo seus critérios, é claro , realizam as construções seletivas dos acontecimentos de acordo com a norma escolhida, 
'escondendo' aquilo que não tem relevo para a tese e destacando os eventos tidos como mais importantes. Realizam, outrossim, a construção semântica dos enunciados, direcionando os termos e expressões a demonstrar que a subsunção dos fatos às normas está correta, assim como buscando convencer o juiz de que seu cliente possui o direito ao bem da vida ${ }^{237}$. Da mesma maneira, constroem enunciados categoriais e culturais, todos com um único intuito: vencer a causa.

Concluído todo o processo construtivo dos enunciados fáticos e jurídicos do ato introdutório, pode-se dizer que a insatisfação sociológica do indivíduo ganha contornos novos, contornos estes de crise jurídica. $\mathrm{O}$ advogado, após toda sua construção, expõe ao juiz um problema de resistência de um direito relativo a um bem da vida, que, segundo sua versão, pertence ao seu cliente. A insatisfação, pois, torna-se uma crise de direito material.

Do que foi dito, dois pontos chamam a atenção.

O primeiro deles é que a escolha da norma e a roupagem jurídica dos fatos são atividades que pertencem à área de incumbência dos advogados e operadores do direito. Em geral, são eles que introduzem elementos de direito ao conflito. São eles, em regra, que qualificam os acontecimentos segundo as normas e institutos vigentes. Toda essa roupagem, portanto, não faz parte do conflito sociológico originário; toda essa carapaça jurídica é adicionada à crise somente no momento de sua entrada no âmbito jurídico. Os fundamentos de direito são, nesse sentido, extrínsecos à insatisfação. ${ }^{238}$

Ademais, deve-se destacar que a dita roupagem é fruto de uma interpretação dos enunciados de fatos e dos documentos pelos advogados. Logo, possuem alto teor de subjetividade. Nesse sentido, pode variar de acordo com o profissional escolhido, o que confere aos elementos jurídicos inseridos na crise, portanto, um mero caráter de sugestão. $^{239}$

\footnotetext{
${ }^{237}$ Para fins de aprofundamento sobre a variabilidade dos termos, DERRIDA, em interessante estudo sob a ótica filosófica desconstrutivista, analisando a oposição entre ato falado e ato escrito, busca estipular técnicas capazes de identificar razões para a eleição de um determinado termo em detrimento de outro em um argumento, texto, etc.. Ver: Of Grammatology, Gayatri Chakravorty Spivak (trad.), Baltimore, 1997, pp. 27, 30 e ss.

${ }^{238}$ A crise existe antes de vir ao judiciário, tal qual o desejo de sua solução. Destarte, para se verificar um conflito, pois, independe diretamente da roupagem jurídica adotada. Nesse sentido, GAmBA, Diritto societario, cit. pp. 404, 411.

${ }^{239}$ DINAMARCO, Instituições, cit. p. 132. Apontando para o caráter meramente sugestivo da formulação dos enunciados jurídicos, tratando da norma e sua estrutura como mero do juiz, ver: JEROME FRANK, Law and the Modern Mind, cit., p. 167; ID., What Courts do in Fact, cit., p. 761.
} 
Além disso, recorda-se que toda a construção advocatícia não é calcada em um juízo de certeza, mas de parcial segurança quanto aos acontecimentos dos fatos. Em outras palavras, os defensores constroem a tese jurídica fundados em alguns enunciados verdadeiros, mas também em vários outros apenas verossímeis, que, ao final, podem apresentar-se como falsos e comprometerem a estrutura pensada.

Não bastasse isso, ainda deve-se ressaltar que toda formulação da tese e as subsunções dos enunciados factuais às normas e institutos são feitas partindo-se de uma posição epistemológica de interesse, parcialidade e envolvimento.

Disso tudo, dessume-se que advogados podem se equivocar na formulação dos enunciados de direito. Quer por interpretação equivocada da situação, quer por uma incompletude e potencial falsidade inerente ao conjunto dos enunciados sobre os quais eles trabalham, ou ainda por deficiência técnica, fato é que um 'erro de cálculo jurídico' é perfeitamente possível na elaboração da definição dos limites de direito da crise sociológica.

Logo, configura-se um equívoco da visão clássica, ao menos pela ótica adotada, afirmar que os fundamentos jurídicos trazidos com a inicial seriam capazes de identificar a demanda. Não parece correto, tudo por um erro de perspectiva, dizer que a estruturação da tese de direito, ou seja, que a roupagem jurídica da crise sociológica, por todas as observações feitas acima, possa, sempre e incondicionalmente, definir a causa de pedir e, conseqüentemente, individualizar a demanda já no ato introdutório. Por esse ângulo, qualquer modificação das qualificações jurídica dos fatos feitas na inicial seria, em absoluto, uma alteração da ação originariamente proposta, o que não se pode aceitar pela vigência do princípio iuria novit curia.

Da mesma forma, conforme sugere a metodologia tradicional, a aplicação dos demais institutos processuais, que segundo ela são dependentes dessa prévia individualização da ação, tais como a coisa julgada, a litispendência e a conexão, estariam sujeitas a elementos subjetivamente construídos, variáveis, parciais e incompletos, o que, como se viu, causa mais problemas que soluções.

Destarte, cabe concluir que também a qualificação jurídica não é um elemento absoluto, capaz de já na fase postulatória identificar definitivamente a extensão da crise e da insatisfação do autor. É, ao contrário disso, um requisito de natureza instrumental, responsável por, em conjunto com os demais, começar a introduzir informações e dados ao 
órgão julgador, que, até aquele momento de propositura, ignorava por completo os dados da realidade intersubjetiva conflituosa.

Diferentemente do caráter absoluto dado pela doutrina clássica, os enunciados com as qualificações jurídicas, pois, tem mero caráter informativo, isto é, são, por todas as características de provisoriedade expostas, veiculadores de dados quanto à insatisfação social entre indivíduos, a qual deverá receber depois de maturada uma solução definitiva conforme o ordenamento. Essa é, portanto, a visão que se crê correta sobre a exigência legal, considerando-a como algo informativo, instrumental e não absoluto.

Feitas essas observações, passa-se, no item subseqüente, à análise dos pedidos da demanda, tema umbilicalmente ligado com as noções até aqui expostas.

\subsection{Da formulação dos pedidos}

Neste momento do trabalho, tendo já discorrido sobre os enunciados de fatos e de direito, far-se-á uma superficial análise sobre a formulação dos pedidos no processo, outro requisito da petição inicial trazida pelo código. Tal como em momentos precedentes, a abordagem do tema será feita por uma perspectiva diversa daquela pela qual, em regra, a doutrina tida como clássica enfrenta o assunto, sempre buscando colocar luzes sobre problemas que são normalmente relegados a um segundo plano.

Se a causa de pedir oferece problemas evidentes - sendo, como se viu, objeto de intermináveis debates doutrinários-, os pedidos, por outro lado, parecem ser algo menos tormentoso. Os estudiosos apontam que, depois de introduzida a crise por meio de relatos fáticos e jurídicos, o autor deverá requerer ao juiz a(s) tutela(s) jurisdicional(is) que ele acredita ser(em) apta(s) a resolver o conflito e atribuir-lhe, como seqüência, o bem da vida em disputa.

Assim sendo, a doutrina, de maneira mais homogênea, costuma apontar que um pedido formulado pelo autor na inicial não é jamais unidirecional, mas sim bifronte. Em outros termos, o autor formula um pedido imediato, consubstanciado na tutela jurisdicional 
compreendida como adequada à resolução do problema introduzido em juízo, além de um pedido de ordem mediata, que constitui exatamente o bem da vida por ele pretendido. ${ }^{240}$

Essas mesmas características podem ser notadas em pedidos do réu em eventual reconvenção ou até mesmo em pedidos declaratórios incidentais.

Entretanto, não obstante a justa identificação da bidirecionalidade do instituto, a doutrina costuma não enfrentar o tema da formação desses mesmos pedidos, bem como deixam de lado o momento de decisão do advogado sobre quais tutelas serão requeridas, questões estas que precedem a análise da natureza da direcionalidade da medida pleiteada. Enganam-se, porém, aqueles que acreditam que o tema não suscita reflexões importantes. Sobre este ponto, pois, crê-se que algumas considerações adicionais devem ser feitas.

Para tanto, invoca-se algo que já fora dito quanto se tratou da formulação dos enunciados jurídicos nos atos processuais: não são as partes que estruturam os pedidos, mas sim seus advogados. Por tratar-se de um elemento técnico, é incumbência dos defensores identificarem a insatisfação de seus clientes, revestirem-nas com os institutos jurídicos e normas do ordenamento e, posteriormente, formularem os pedidos de tutelas jurisdicionais corretas para aquela determinada situação. Ao autor cabe apenas e tão somente dizer qual o bem da vida é que deseja. O ponto é importante e merece algumas reflexões ulteriores.

Disse-se em momento precedente que os advogados, após estudarem o caso, criarão com base em normas estrategicamente escolhidas uma tese jurídica pela qual buscarão convencer o juiz a atribuir ao seu cliente o bem da vida por ele desejado. A tese referida e que irá sustentar a pretensão de seu cliente nada mais é do que uma roupagem técnica dada ao conflito sociológico. Os profissionais selecionam os fatos importantes mediante a escolha de normas e institutos que entendem aplicáveis ao caso, formulando assim os enunciados fáticos e jurídicos que comporão a inicial (ou reconvenção, por exemplo). Depois disso, os advogados deverão formular os pedidos por meio dos quais solicita uma tutela jurídica que, segundo toda a construção e as escolhas anteriormente feitas por ele,

\footnotetext{
${ }^{240}$ Por todos: "Esse pedido, entretanto, não é único, mas sim bifronte. Subdivide-se em pedido imediato e pedido mediato. O pedido imediato é a tutela jurisdicional requerida pelo autor ao Poder Judiciário, que é apta a solucionar a crise de direito material que lhe é apresentada (tutelas de conhecimento, cautelares, executivas etc.). O pedido mediato, por seu turno, é o próprio bem da vida que o autor pretende lhe seja concedido, segundo normas de direito material previamente traçadas pelo legislador". HENRIQUES DA COSTA, O Processo Coletivo na Defesa do Patrimônio Público e da Moralidade Administrativa, São Paulo, 2009, pp. 141-142.
} 
seja capaz de resolver a crise exposta à apreciação do juiz. Tecnicamente, é a natureza do problema substancial - dada pela construção técnica e subjetiva do conflito - que define e reclama um determinado tipo específico de tutela jurisdicional. ${ }^{241}$

Desse modo, o advogado do autor - ou do eventual réu-reconvinte - deverá, de acordo com as escolhas técnicas feitas por ele ao construir os enunciados jurídicos, analisar a crise de direito material existente e, dentre as tutelas possíveis, escolher o remédio apto a resolver o problema por ele proposto. Por óbvio, uma insatisfação poderá apresentar uma série de crises das mais variadas naturezas - tudo a depender da forma como o operador do direito revestiu o conflito-, levando-o a pleitear mais de uma tutela.

Quanto ao ponto, vale ressaltar, importante seria que o advogado, em debate com o cliente, explicitasse qual a tese escolhida, quais os fatos selecionados, além de quais institutos jurídicos foram usados para envolver a crise, delimitando e identificando em conjunto quais as tutelas que deverão ser requeridas. Nessa hipótese, a abrangência da decisão do juiz seria delimitada em comum acordo com o cliente.

Para aclarar o que se quer fazer entender, toma-se como exemplo um hipotético negócio jurídico, o qual teve como declarante da vontade alguém com fundado temor de dano iminente e considerável à sua pessoa, à sua família, ou aos seus bens. Instado a cumprir a obrigação pela contra parte, o paciente, pretendendo não arcar com a obrigação ali prevista, procura um advogado que, dentre o cenário fático contado pelo sujeito, destacará os acontecimentos mais relevantes para a configuração do instituto da coação, formulando seus enunciados fáticos e jurídicos orientados a convencer o juiz de que o indivíduo declarante, seu cliente, não deve cumprir aquilo que foi avençado e que está sendo exigido pelo outro contratante. Nesse cenário, ideal que o operador do direito formule os pedidos de tutela em consonância com os limites da insatisfação de seu cliente, que, no caso proposto, pode ser com todo o contrato ou tão somente com a fonte da obrigação exigida. A depender da situação, os pedidos serão mais ou menos abrangentes.

Destarte, em síntese do que fora dito até aqui, o advogado formula os pedidos de acordo com os limites da insatisfação de seu cliente, a qual foi revestida com a tese jurídica

\footnotetext{
${ }^{241}$ Essa também parece ser a visão de BEDAQUE. Em suas palavras: "Não parece correto, todavia, afirmar seja a tutela jurisdicional pleiteada o elemento a determinar a natureza do interesse deduzido em juízo. Ao contrário, é o tipo de direito que determina a espécie de tutela", Direito e Processo - influência do direito material sobre o processo, São Paulo 2006, p. 40. No mesmo sentido, Proto PISANI, I Diritti e le Tutele, Napoli, 2008, pp. 54-55.
} 
criada por ele próprio e que, a depender do que fora estruturado, requererá um determinado tipo específico de tutela.

Antes de adentrar nos problemas que o tema suscita, algumas considerações de ordem técnica e teórica deverão ser traçadas. Cabe analisar, portanto, individualmente cada uma das tutelas jurisdicionais de conhecimento e seus efeitos jurídicos, iniciando-se pela tutela declaratória, passando-se em seguida à constitutiva e, posteriormente, à condenatória. $^{242}$

Afirmou-se em momento anterior que a insatisfação dos sujeitos é revestida pelos seus advogados com uma roupagem jurídica - fruto de uma construção com envolvimento de uma tese defensiva dos interesses de seus clientes -, que adquire, pois, contornos e nuances de crise de direito material no momento de entrada no âmbito processual. Cada crise tem como apta à sua resolução uma determinada tutela.

Notam-se, segundo os critérios adotados pela doutrina ternária, que três são as naturezas das crises existentes nas relações substanciais. São elas: a) a crise de incerteza; b) uma resistência quanto ao exercício e efetivação de um direito potestativo; e c) uma crise de inadimplemento. Cada uma dessas crises é resolvida por uma determinada tutela jurisdicional, que pode ser a 'meramente' declaratória, a constitutiva ou a condenatória, respectivamente.

A tutela (meramente) declaratória visa a eliminar uma crise de incerteza quanto a uma determinada relação jurídica material. ANGELO FALZEA, em trabalho dedicado à temática geral, tanto no âmbito processual como na esfera dos negócios jurídicos, diz ser a

\footnotetext{
${ }^{242}$ Não se desconhece a corrente doutrinária, capitaneada no Brasil por PONTES DE MIRANDA, influenciado pela doutrina alemã, com grande reverberação entre os doutrinadores gaúchos, que dividem as tutelas jurisdicionais em cinco categorias: a) meramente declaratória; b) constitutiva; c) condenatória; d mandamental; e e) executiva lato senso. Entretanto, acredita-se que o critério de classificação utilizado por essa doutrina, denominada de quinaria, não é homogêneo, vez que mistura a natureza da crise de direito material com a forma de cumprimento e efetivação da sentença. Por essa razão, adota-se na integralidade a crítica feita por BARBOSA MOREIRA, que, alertando sobre os perigos e inconvenientes de uma classificação por meio de critérios heterogêneos, afirma: "Permita-me temperar com uma pitada de humor a aridez desta palestra. Em interessante ensaio de processualista italiano, colhe-se a informação de que, numa velha enciclopédia chinesa, os animais se viam distribuídos nas seguintes quatorze classes: $1^{\mathrm{a}}$ ) pertencentes ao imperador; $2^{\mathrm{a}}$ ) embalsamados; $3^{\mathrm{a}}$ ) amestrados; $4^{\mathrm{a}}$ ) bacorinhos; $5^{\mathrm{a}}$ ) sereias; $6^{\mathrm{a}}$ ) fabulosos; $7^{\mathrm{a}}$ ) cães vagabundos; $8^{\mathrm{a}}$ ) incluídos nesta classificação; $9^{\mathrm{a}}$ ) que se agitam como loucos; $10^{\mathrm{a}}$ ) inumeráveis; $11^{\mathrm{a}}$ ) desenhados com pincel finíssimo de pelo de camelo; $12^{\mathrm{a}}$ ) etc.; $13^{\mathrm{a}}$ ) que quebram o vaso; $14^{\mathrm{a}}$ ) que de longe parecem moscas. $\mathrm{O}$ caso pode ser anedótico; nem por isso deixa de ser útil para alertar-nos , ao mesmo tempo, contra o perigo de misturar critérios e de exagerar na respectiva dosagem. Convém ter presente esse pitoresco exemplo todas as vezes que nos sentirmos tentados a dar rédea solta ao nosso animus classificandi, antes que ele tome o freio nos dentes e se transforme em cego e obsessivo furor classificandi". Questões Velhas e Novas em Matéria de Classificação das Sentenças in Temas de Direito Processual - oitava série, São Paulo, 2004, p. 142.
} 
declaração uma denotação de um processo subjetivo ativamente orientado em direção a uma situação de espírito de certeza. O mesmo autor define certeza como uma modalidade da consciência: "la conoscenza dei fenomeni della realtà in noi e fuori di noi può essere più o meno problematica: certezza è conoscenza non problematica di um qualunque fenomeno che perciò appare al soggeto come fenômeno reale, suscettibile di formare il contenuto di uma affermazione vera". ${ }^{243}$

Desse modo, declaração é o ponto último de um processo subjetivo evolutivo, que se inicia com a dúvida quanto a uma determinada realidade e alcança ao final o estado de certeza, base para a emissão da declaração.

Esse raciocínio de ordem geral pode ser transplantado ao fenômeno do processo jurisdicional. Se no plano do direito material houver dúvida referente à existência, à validade, à originalidade de um documento ${ }^{244}$, isto é, existir qualquer crise ligada a uma situação de incerteza, positiva ou negativa, poderá o advogado do indivíduo insatisfeito requerer uma tutela declaratória para sanar este problema.

Esta demanda, por meio de sua fase instrutória, fará com que a realidade subjetivamente existente no espírito do juiz quanto a uma relação jurídica alegada - que no início restringe-se às alegações contidas na petição inicial e aos fatos narrados pelo advogado do autor - torne-se coerente com a realidade existente "fuori" dele, estando nesse momento pronto para proferir uma declaração quanto ao ponto duvidoso, atribuindo ou negando certeza à situação posta em debate.

Assim, a crise é afastada, tal como a insatisfação dos litigantes, como o mero declarar do juiz, que, pela imperatividade estatal que possui, impõe a atribuição de certeza quanto à relação jurídica duvidosa. ${ }^{245}$

Desse modo, a tutela jurisdicional declaratória, negativa ou positiva, tem como efeito jurídico próprio a eliminação da dúvida quanto a uma determinada situação. Ao

\footnotetext{
${ }^{243}$ Accertamento in Enc. dir., vol. I, Milano, 1968, p. 206.

${ }^{244} \mathrm{Ou}$, pelo viés negativo, de inexistência, invalidade, não originalidade etc.

${ }^{245}$ Nesse sentido: "cioè a quelle ipotesi in cui l'attore si limita a domandare al giudice di dichiarare se un determinato diritto esiste o no esiste, e il bisogno di tutela giurisdizionale è soddisfatto dalla sola autorità di cosa giudicata, dalla sola immutabilità dell' accertamento contenutto nella sentenza in tutti futuri giudizi tra le stesse parti (o i loro eredi e aventi causa) nei quali il diritto accertato sia dedotto come petitum o come elemento della fattispecie di un diverso diritto che a sua volta costituisce il petitum". Proto PISANI, Tutela di Mero Accertamento in I Diritti e le Tutele, Napoli, 2008, p. 43.
} 
declarar a forma como deve ser encarada, elimina-se a crise de direito material atribuindolhe certeza, que deverá ser levada em conta nas relações entre as partes envolvidas.

Muitos são os efeitos existentes dessa tutela, tanto de natureza prática como jurídica $^{246}$. Narrá-los, contudo, além de ser uma atividade enfadonha, fugiria do propósito do presente trabalho. Todavia, destaca-se que por ser destinada a eliminar uma dúvida existente quanto a uma determinada situação jurídica, a tutela declaratória é dotada de eficácia ex tunc. Isso por uma razão lógica: o juiz se manifestará sobre uma situação já presente. Não a modificará, criará ou a extinguirá, apenas e tão somente dará certeza a um estado de dúvida sobre algo existente ou inexistente, válido ou inválido etc.

A outra crise de direito material que se fez referência foi aquela ligada à efetivação de um direito potestativo. Tal direito consubstancia-se em uma formulação poder-sujeição. Poder ao titular do direito de exigir algo; sujeição de alguém que nada poderá fazer para que aquele direito se efetive. Há uma submissão de um indivíduo frente ao desejo do titular do direito, nada importando sua vontade para a criação, extinção ou modificação de uma situação jurídica que o envolva. ${ }^{247}$

É justamente para dar efetividade a um direito potestativo que a tutela constitutiva se destina. Logo, se a insatisfação de um sujeito é revestida por seu advogado como sendo um direito dessa natureza, deverá ele requerer, se se busca um comportamento coerente, uma tutela dessa espécie. ${ }^{248}$

No âmbito do direito nacional, percebe-se que o código de processo não possui normas que prevêem expressamente uma ação constitutiva. Entretanto, a existência das

\footnotetext{
246 Traçando apontamentos da doutrina italiana, ANGElo FALZEA diz que, em geral, três são os efeitos jurídicos apontados pelos estudiosos: um constitutivo, um declaratório e um preclusivo. O citado autor refuta o primeiro e fica com os dois últimos. Para maiores aprofundamentos, ver: Accertamento, cit., pp. 205-219.

${ }^{247}$ Essas são as palavras de CAIO MÁRIO DA SILVA PEREIRA: "Direitos Potestativos. Entre as outras situações jurídicas que o ordenamento reconhece estão aquelas que podem ser expressas pela formulação podersujeição: poder do titular do direito de um lado, sujeição de alguém para com o exercício do direito de outrem. Esta situação se diferencia da anterior porque, neste caso, não há dever, mas apenas submissão à manifestação unilateral do titular do direito, embora a manifestação atinja a esfera jurídica do outro, constituindo, modificando ou extinguindo uma situação jurídica subjetiva”, Instituições de Direito Civil, I, Rio de Janeiro, 2008, p. 37.

248 ANDREA PROTO PISANI, em estudo destinado à análise das tutelas constitutivas, traz crítica bastante interessante quanto ao regramento italiano. Segundo ele, o artigo 2.908 do código civil peninsular, que prevê que a autoridade judiciária poderá, nos casos previstos em lei, constituir, modificar ou extinguir relações jurídicas entre as partes, consubstancia-se em uma exceção do sistema. Lá, a norma geral e abstrata não dita a disciplina dos interesses em conflito, relegando à autonomia privada ou ao poder administrativo tal regulamentação. Nesse sentido, La Tutela Costitutiva in I Diritti e le Tutele, cit., p. 125.
} 
tutelas dessa natureza pode ser extraída da sistemática geral constitucional e do princípio da inafastabilidade da jurisdição (art. 5º inciso XXXV, da Constituição da República). ${ }^{249}$

Aqui, semelhantemente ao que ocorre em outros países, a autonomia privada é a grande responsável por fixar direitos potestativos entre os sujeitos. Exemplo disso, dentre outros, são as cláusulas rescisórias por inadimplemento contratual. Em caso de uma das partes não adimplir sua obrigação, poderá a outra rescindir o negócio ainda que a primeira desejar permanecer com a relação incólume.

A crise no plano do direito material, nesses casos, se dá em duas circunstâncias: a) quando o sujeito que anseia a extinção, criação ou modificação de uma situação encontra resistência de outrem, que, em geral, é quem deveria se sujeitar à sua vontade, porém não o faz; ou b) quando a própria lei impede que o indivíduo faça as alterações situacionais espontaneamente, ainda que aquele que tenha que se sujeitar ao seu interesse não apresente óbices. No primeiro caso, está-se diante das ações constitutivas voluntárias, ao passo que no segundo têm-se as constitutivas necessárias. ${ }^{250}$

Nota-se, nesse sentido, que os efeitos jurídicos próprios dessa tutela são: a) o reconhecimento de um direito potestativo ao autor (momento declaratório) e a extinção, criação ou modificação de uma situação (momento constitutivo). Há, portanto, dois momentos lógicos da tutela, o reconhecimento e a posterior alteração no mundo jurídico relacional, sendo o segundo necessariamente dependente do primeiro. ${ }^{251}$

Tais quais as tutelas declaratórias, as constitutivas não necessitam de atos futuros para se concretizarem. Não é necessário, por óbvio, atos de expropriação ou mesmo de execução para a satisfação integral da pretensão do autor.

Contudo, diferentemente das tutelas declaratórias, a eficácia das constitutivas é, via de regra, ex nunc ${ }^{252}$, isto é, projeta seus efeitos para o futuro. Isso ocorre por motivos

\footnotetext{
249 Nesse mesmo sentido, CÂNDIDO RANGEl DinAMARCO afirma: "Em momento algum o Código de Processo Civil faz qualquer alusão genérica e ampla à tutela constitutiva ou às sentenças dessa ordem. Inferese o direito àquelas e a estas, diretamente, da garantia da ação como cobertura geral dos direitos, sem a qual estes ficariam expostos à não efetividade e portanto o acesso à justiça estaria comprometido", Instituições de Direito Processual Civil, III, São Paulo, 2009, p. 254.

${ }^{250}$ Ibidem, p. 255.

${ }^{251}$ Ibidem, p. 257.

${ }^{252}$ Utilizou-se a expressão "via de regra" porque o código civil, por exemplo, traz casos atípicos, pois passíveis de serem resolvidos por tutelas constitutivas (anulação de negócio jurídico) que, entretanto, projetam seus efeitos para o passado (art. 182, CC).
} 
lógicos: se o que se quer é justamente modificar, criar ou extinguir alguma relação, querse, ao final e a cabo, alterar as circunstâncias pré-existentes. A insatisfação é justamente com o estado originário das coisas, pretendendo o advogado do autor com as alterações da situação inicial atribuir-lhe o bem da vida. ${ }^{253}$

Destarte, a tutela constitutiva, em síntese, possui como efeitos jurídicos próprios o reconhecimento de um direito potestativo e a criação, alteração ou extinção de situações jurídicas no plano material, projetando seus efeitos para o futuro.

Por fim, a tutela condenatória, ao longo de todo o tempo, naquilo que tange à sua estrutura, é tratada por um viés predominantemente endoprocessual. Mais precisamente, a doutrina tem identificado como um de seus principais efeitos a produção de um título executivo judicial apto a abrir a fase executória (antigo processo de execução) com o objetivo de satisfazer a pretensão do credor, vencedor da demanda condenatória.

Na Itália, segundo informações de ANDREA PROTO PISANI, a doutrina costuma apontar três elementos que diferenciam a tutela jurisdicional condenatória daquela denominada meramente declaratória. Esses elementos consistiriam na aptidão da tutela de condenação em: a) constituir título executivo nos moldes do art. 474, nº 1 , do Código de Processo Civil italiano; b) constituir título para a inscrição de hipoteca judicial tal como dispõe o art. 2.818 do mesmo diploma; e c) substituir a prescrição ordinária pela eventual originária prescrição mais breve, no sentido indicado pelo art. 2.953 do CPC peninsular. ${ }^{254}$

Dando relevância também à formação de um título que possibilite a abertura da execução, CÂNDIDO RANGEL DINAMARCO aponta que as sentenças condenatórias possuem dois momentos lógicos que compõem sua estrutura, são eles: a) uma declaração como toda sentença de mérito; e b) a "criação de condições para que a execução passe a ser admissível no caso, isto é, para que ela venha a ser a via adequada para o titular do

253 Nesse mesmo sentido, LIEBMAN assim se posiciona: "Sabe-se que, segundo autorizada doutrina, a atividade exercida pelo juiz, ao prolatar uma sentença constitutiva, não é diversa daquela que exerce quando faz uma simples declaração e que os efeitos constitutivos se seguem, por força de lei, à própria declaração. Não me parece, contudo, aceitável essa concepção, visto considerar que na prolação da sentença constitutiva a atividade do juiz se dirige propriamente à produção de uma alteração jurídica. A ideia mesma de uma declaração com efeitos constitutivos parece-me contraditória, porque a operação com que se aplica uma norma ao caso concreto só se pode considerar atividade de declaração enquanto sejam os seus efeitos meramente declaratórios, isto é, enquanto consistam em fixar as relações jurídicas tais quais eram precedentemente e não em modificá-las", Eficácia e Autoridade da Sentença, Alfredo Buzaid e Benvindo Aires (trad.), Rio de Janeiro, 1984, p. 26.

${ }^{254}$ Tutela di Condanna in I Diritti e le Tutele, cit., p. 73. 
direito buscar sua satisfação" ${ }^{\text {255 }}$, segundo momento esse que a distingue das demais sentenças.

Inobstante a grande autoridade dos mencionados autores, eleitos por esse trabalho para representarem grande parte dos doutrinadores quanto ao ponto tratado - sejam eles brasileiros ou estrangeiros - justamente pela coerência e sensibilidade com que construíram toda sua obra e com que tratam o processo, pede-se licença para deles discordar, ou, por outro lado, para adotar outra perspectiva.

Acredita-se, com todo respeito, que a visão ali externada relega, ainda que momentaneamente, a insatisfação do indivíduo e a formulação da crise de direito material e, por conseqüência, a própria relação jurídica material invocada pela parte-, a um segundo plano $^{256}$. Entretanto, segundo a perspectiva aqui adotada, a análise da tutela jurisdicional deverá ser tomada pela a crise existente e seus efeitos após sua resolução.

E para tanto, como já dito anteriormente, faz-se alusão ao inadimplemento, crise passível de resolução por meio da tutela aqui tratada. Para um correto entendimento do objeto de estudo deste tópico, esse conceito de direito material deverá ser examinado com atenção, sob pena de se cair na própria crítica aqui trazida: abandono do direito substancial.

Inadimplemento, como a intuição aponta, pressupõe uma relação obrigacional que tenha como fonte ou um ato jurídico não-negocial (como, por exemplo, atos jurídicos stricto senso, atos ilícitos, abusos de direito etc.) ou os negócios jurídicos (bilaterais ou unilaterais $)^{257}$, que devem ser existentes, válidos e eficazes. Isto é, não se pode falar em inadimplemento sem obrigação, e esta sem uma fonte. Assim, havendo uma obrigação não cumprida - seja voluntaria ou involuntariamente - tem-se o inadimplemento. ${ }^{258}$

Não bastasse isso, para que haja inadimplência por parte do devedor, imprescindível a obrigação ser exigível. Assim, para se demonstrar a inexistência do

${ }^{255}$ Instituições, III, cit., p. 234.

${ }^{256}$ Quanto ao primeiro autor, cabe notar que a própria obra aqui citada inicia tratando da relação entre direito material e direito processual. Em relação a Cândido Rangel Dinamarco e sua obra, bastam as palavras de MICHELE TARUFFO: “Traggo questa sintetica definizione dall'opera più importante in matéria di strumentalità e finalità del processo, ossia Dinamarco, A instrumentalidade do Processo (...)", Il processo Civile di Civil Law e di Common Law: Aspetti Fondamentale in Sui Limiti, Bologna: Il Mulino, 2002, p. 95. Logo, definitivamente, não se afirma aqui que tais autores não se atentem ao direito material, o que seria um absurdo e uma injustiça por parte do autor do presente trabalho.

${ }^{257}$ ORLANDO GOMES, Obrigações, Rio de Janeiro: Forense, 2008, p. 38

${ }^{258}$ Nas palavras de Orlando Gomes: "Verifica-se o inadimplemento, no sentido estreito do vocábulo, quando o devedor não cumpre a obrigação, voluntária ou involuntariamente", Obrigações, cit., p. 173. 
inadimplemento ante a uma relação obrigacional existente e válida, porém inexigível, fazse referência às obrigações naturais ou imperfeitas, que podem ser conceituadas como "obrigação sem sanção, sem ação para se fazer exigível"259. Assim, não basta existir a obrigação. Para que se possa cobrá-la é imprescindível que ela seja exigível.

Nesse sentido, as tutelas condenatórias buscam eliminar as crises de inadimplemento. Uma ação que pleiteia uma tutela dessa natureza, para que tenha um desfecho de procedência, deve trazer ao processo como revestimento jurídico da insatisfação uma obrigação tida por inadimplida, que pode ser de dar, fazer ou não fazer.

Destarte, a título de elucidação, se um autor formula um pedido de tutela condenatória fundado em uma obrigação natural, a ação deverá, certamente, ser julgada improcedente. Entretanto, apenas como exercício de raciocínio, poder-se-ia pensar que se o mesmo autor formulasse pedido declaratório de existência da mesma relação obrigacional, a ação, diferentemente do exemplo anterior, deveria ser julgada procedente, pois a obrigação existe e é válida, somente não sendo exigível.

O mesmo se diga de obrigações com outras fontes que não a negocial. Em casos de ato ilícito, por exemplo, estando prescrito o dever de indenizar, não poderá ser concedida a tutela de condenação, mas a relação obrigacional permanece existente, somente tendo perdido sua exigibilidade (art. 189, do CC). ${ }^{260}$

Ante à exposição anterior, pode-se notar um destaque dado ao elemento "inadimplemento" para a concessão da tutela condenatória.

Assim, para que possa ser concedida, uma tutela condenatória deverá, obrigatoriamente, reconhecer a existência do inadimplemento da obrigação trazida pelo autor. Esse é, pois, segundo a visão adotada, o caráter diferenciador das tutelas de condenação.

Aliás, cabe aqui uma observação: a fase de execução se dá justamente em função de uma característica dessa relação obrigacional inadimplida, qual seja, sua exigibilidade, somada a um efeito jurídico secundário da sentença condenatória, isto é, a capacidade de ser título executivo, característica atribuída por lei. Assim, a criação de condições para

\footnotetext{
${ }^{259}$ CAIO MÁRIO DA SILVA PEREIRA, Instituições, cit., p. 28.

${ }^{260}$ Sendo, dessa maneira, apta a tutela declaratória de existência da dívida. Se há ou não utilidade uma tutela desse gênero para as relações factuais entre indivíduos, isso é tema para ser analisado em momento posterior. O que se busca afirmar é que o ordenamento, segundo sua estrutura, autoriza tecnicamente esse raciocínio.
} 
execução, antes de ser um segundo momento lógico da sentença, é um reflexo da exeqüibilidade da obrigação reconhecidamente inadimplida. Tanto é assim que os processos executórios fundados em títulos extrajudiciais serão integralmente satisfativos se a obrigação plasmada no título tiver exigibilidade, independentemente de uma tutela condenatória previamente concedida. Em caso de inexistência dessa característica (exigibilidade), dever-se-á extinguir o feito executivo.

Em suma, a tutela jurisdicional condenatória visa a eliminar a crise de inadimplemento existente no plano material. Para tanto, deve reconhecer na obrigação exposta pelo advogado do autor uma característica específica, qual seja, a inadimplência (que pressupõe uma obrigação exeqüível), reconhecimento esse que faz da sentença condenatória um título apto a iniciar a execução, momento em que o bem da vida será entregue a quem tem direito.

Ademais, e por fim, cabe pontuar que justamente devido à própria natureza da crise em debate, a satisfação do detentor do direito, diferentemente das tutelas declaratórias e constitutivas, não é imediata. Como se trata de um inadimplemento de uma obrigação, um dar, um fazer ou um não fazer restou não realizado por parte de quem deveria cumpri-la. E, para que isso ocorra, além do reconhecimento da situação de inadimplemento relativo a uma obrigação exigível - que pode influenciar um adimplemento espontâneo -, deve-se, por óbvio, em caso de resistência, lançar mãos de atos imperativos executórios.

Exatamente por isso é que se diz que as tutelas condenatórias possuem limitação funcional de sua eficácia ${ }^{261}$, pois, como tutela de conhecimento, somente poderá reconhecer o não cumprimento de uma obrigação, que, se exigível, autorizará a execução. Ela em si, contudo, não tem a capacidade de atribuir o bem da vida ao credor, titular do direito e solucionar as insatisfações. Nota-se, portanto, que não há a satisfação da pretensão do autor apenas com os efeitos jurídicos próprios da tutela condenatória (reconhecimento do inadimplemento), necessitando de algo a mais.

Diante dessas observações, algumas conclusões podem ser traçadas. A primeira delas é que tanto o enquadramento jurídico quanto os pedidos, elementos interligados entre

\footnotetext{
261 Apontando para essa limitação devido à natureza do problema, CÂNDIDO DINAMARCO afirma: "Essa limitação funcional da eficácia da tutela jurisdicional condenatória é associada ao próprio modo-de-ser da crise jurídica que lhe dá fundamento. Se o que falta é o inadimplemento da obrigação, ou seja, a prestação com que o obrigado entregaria o bem ou realizaria o fazer devido, uma simples sentença não teria o poder de produzir no mundo das coisas essa modificação prática”, Instituições, III, cit., pp. 235-236.
} 
si, não são originários da insatisfação oriunda das relações intersubjetivas dos indivíduos. São, isso sim, requisitos técnicos incorporados ao problema sociológico no momento de entrada no processo, tal como requer o Código de Processo Civil, atividade essa, em geral, de incumbência dos advogados. A atribuição de roupagem jurídica aos fatos da insatisfação, entretanto, é fruto de uma interpretação por parte dos operadores do direito dos relatos do sujeito insatisfeito, bem como dos documentos e demais materiais por ele apresentado. Logo, a tese de defesa tem caráter parcial e subjetivo, sendo ela calcada em asserções que podem ser verdadeiras, verossímeis e potencialmente falsas, o que lhe atribui um importante caráter de variabilidade.

Os pedidos de tutela jurisdicionais são, outrossim, incumbência dos procuradores das partes e, como se disse, vinculados à tese e à estrutura jurídica por eles próprios formulados. Dessa maneira, também eles são variáveis de acordo com o entendimento daquele que os formularam.

Justamente por essa variabilidade é que se entende ser equivocada a visão doutrinária e jurisprudencial que atribui ao pedido o caráter de elemento absoluto de identificação da demanda ${ }^{262}$. Diferentemente disso, crê-se, pela perspectiva até aqui adotada, que os pedidos, tais quais os enunciados de fato e de direito, são elementos que possuem a função instrumental de aporte de informações sobre a insatisfação dos indivíduos. Desse modo, possuem um caráter meramente indicativo, sem que haja, obrigatoriamente, uma vinculação dos limites da crise sociológica à natureza da tutela formulada.

É bem verdade que as observações feitas não podem ser levadas a um ponto extremo e aplicáveis sem quaisquer restrições. Em um sistema no qual o princípio dispositivo do direito material é a baliza regente, não se pode, livre de qualquer cautela, admitir que o juiz ignore por completo o pedido formulado na inicial. Algumas ulteriores observações quanto a esse princípio serão traçadas em momento oportuno. Contudo, o que se busca demonstrar é que até mesmo ele, o petitum, não é absoluto e restritivo, tal como em geral é apontado.

Não são raros os casos em que o julgador afasta o pedido tal como formulado e atribui à parte uma tutela apta a resolver a crise em seus reais limites. É possível imaginar

${ }^{262}$ Como já citado, ScHWAB, Objeto litigioso, cit. passim. 
situações nas quais as tutelas requeridas - quer por equívocos redacionais, por deficiências técnicas do operador do direito ou por qualquer outro motivo - não são as mais adequadas para solucionar a crise material (e, conseqüentemente, sociológica) conforme a situação exposta e delimitada ao longo do processo, cabendo ao órgão julgador 'ajustar' a natureza no momento da sentença. Em outras palavras, podem-se verificar casos em que, a despeito de a tese jurídica construída pelo advogado exigir um determinado tipo de tutela, ele formula o pedido requerendo um provimento jurisdicional não adequado, isto é, diferente daquele apto a solucionar aquela determinada crise de direito material. Os juízes, como se nota na prática, relevam o equívoco e atribuem, de acordo com a natureza da crise, a tutela ajustada.

Quanto ao ponto em debate, pode-se fazer remissão a alguns exemplos. O quotidiano forense mostra que inúmeras ações são propostas não só com o nomen iuris equivocado, como as ditas ações revisionais de contrato bancário cumuladas com repetição de indébito, mas também com pedidos notoriamente equivocados. Nessas ações, nota-se que o indivíduo insatisfeito procura um advogado por acreditar que o valor a ser pago às instituições financeiras, comparado ao valor que teve à sua disposição, é desequilibrado e desproporcional. Com certa freqüência, o advogado, a parte as inúmeras taxas tidas por ele como ilegais, formula um pedido de revisão contratual, que nada mais é que uma tutela constitutiva, cumulando-a com o pedido condenatório de devolução de parte dos valores pagos, tomando como fundamento para tanto a vedação pelo ordenamento jurídico da prática de anatocismo, que, em regra, é previsto pelo contrato.

Ora, se a construção da roupagem jurídica da insatisfação fosse considerada em seus estreitos limites, a correta interpretação do caso exigiria, ao contrário do que de fato acontece, uma tutela declaratória de nulidade, uma vez que, de acordo com os fundamentos jurídicos, o objeto da cláusula que autoriza a cobrança de juros sobre juros é ilícito e, portanto, a obrigação seria nula, não produzindo, pois, quaisquer efeitos (Código Civil, art. 166, II). A anulabilidade do dispositivo contratual, consistente na revisão de suas cláusulas, não ensejaria, por outro lado, a requerida repetição do indébito (tutela condenatória), já que o negócio, até então, teria produzido seus regulares efeitos e só após a sentença desconstitutiva é que os veria cessados (CC, art. 177). A cumulação entre repetição do indébito (condenação) e anulabilidade (constitutiva negativa, no caso) ensejaria a inépcia 
da inicial, pois incompatíveis os pedidos entre si à luz do ordenamento material civil, ensejando com isso a extinção do feito. ${ }^{263}$

Entretanto, no caso em análise, a crise de direito material e a insatisfação do autor são facilmente compreensíveis independentemente da atecnia apontada. Tanto o órgão julgador quanto a instituição financeira ré conseguem extrair os limites mínimos daquilo que o devedor deseja, bem como qual a natureza jurídica que fora atribuída aos fatos pelo advogado do autor. O pedido, da maneira como formulado, passa a ser quase que irrelevante para que se compreenda o que quer o sujeito insatisfeito. ${ }^{264}$

Logo, conclui-se que também o pedido, se analisado pela ótica epistemológica de sua formação, não é um elemento absoluto, claramente definido e necessariamente responsável por identificar os limites da crise apresentada em juízo já na petição inicial, visão essa que bloqueia durante todo o processo o material posto sob análise do juiz nas asserções parciais, incompletas e potencialmente falsas. ${ }^{265}$

Ao contrário, o pedido, tais quais os demais enunciados das partes, possuem todas as características epistemológicas dos atos produzidos por pessoas envolvidas, devendo ser

\footnotetext{
${ }^{263}$ Tais ações, por já haver entendimento solidificado nos tribunais quanto ao tema, são, em geral, julgadas improcedentes. Ocorre, porém, que a simples apreciação do mérito por parte dos juízes demonstra que a atecnia dos pedidos foi afastada. Nesse sentido: TJSP, 22 ${ }^{\text {a }}$ Câmara de Direito Privado, Apelação 001064608.2013.8.26.0554, Rel. Des. Hélio Nogueira, j. 30.10.2014; TJSP, $15^{\text {a }}$ Câmara de Direito Privado, Apelação 3000662-22.2013.8.26.0368, Rel. Des. Coelho Mendes, j. 28.10.2014; TJSP, $22^{\mathrm{a}}$ Câmara de Direito Privado, Apelação $\mathrm{n}^{\circ}$ 9217875-31.2009.8.26.0000, Rel. Des. Fabio Tabosa, j. 10.10.2013. Outras poucas vezes, quando julgadas procedentes, a devolução das quantias pagas (restituição do indébito) é indicativa de que o entendimento foi no sentido de que a cláusula contratual que prevê o anatocismo é nula, não anulável, tal como geralmente requerido. Por fim, muitos julgadores se utilizam, percebendo-se do equívoco técnico do operador do direito, expressões como "dita ação revisional", "alegada revisão contratual", dentre outras, apontando para o fato de serem ações declaratórias de nulidade. É o que se nota: TJSP, $22^{\text {a }}$ Câmara de Direito Privado, Apelação 0008773-29.2012.8.26.0482, Rel. Des. Fabio Tabosa, j. 14.03.2013; TJSP, $22^{a}$ Câmara de Direito Privado, Apelação 0000429-06.2012.8.26.0047, Rel. Des. Fabio Tabosa, j. 06.12.2012.
}

${ }^{264}$ Por uma perspectiva clássica, CRISANTO MANDRIOLI, em estudo destinado à análise dos pedidos e das causas de pedir no processo, já havia apontado para um esquema pendular de identificação da crise, relativizando o caráter absoluto dado aos dois institutos na técnica de identificação da ação (Riflessioni in tema di 'petitum' e di 'causa petendi', in Rev. dir. proc., 1984, 3, pp. 465 e ss. Ocorre, porém, que ainda que luzes tenham sido postas sobre a relatividade do pedido e da causa petendi, a metodologia da identificação da ação usada pelo autor mantinha tais elementos restritos aos atos iniciais das partes.

265 Expressamente, o Superior Tribunal de Justiça aceitou a chamada interpretação lógico-sistemática do pedido, ignorando-o em sua acepção redacional e atribuindo o que realmente se desejava. Nesse sentido de pedido como informador, assim se manifestou o Ministro Relator: "a obrigatória adstrição do julgador ao pedido expressamente formulado pelo autor pode ser mitigada em observância dos brocardos da 'mihi factum dabo tibi ius' (dá-me os fatos que te darei o direito) e 'iura novit curia"', STJ, REsp 1197476, Terceira Turma Julgadora, Rel. Ministro Ricardo Villas Bôas Cueva, DJe 10/10/2014. Na mesma linha, "o pedido não é apenas o que foi requerido em um capítulo específico ao final da petição inicial, mas, sim, o que se pretende com a instauração da demanda, sendo extraído de interpretação lógico-sistemática da inicial como um todo" STJ, AgRg no REsp 1284020, Segunda Turma Julgadora, Rel. Ministro Humberto Martins, , DJe 06/03/2014. 
tomado apenas e tão somente como portador de informações sobre a crise, tendo como função trazer ao juiz informações sobre aquilo que se busca resolver no plano fenomênico entre os envolvidos.

Vistas essas características das formações dos atos introdutórios e das primeiras manifestações das partes, crê-se ser possível, embora algumas rasas observações já tenham sido traçadas, avançar no estudo e verificar qual o impacto dessas limitações na formação da decisão e, conseqüentemente, na resolução da crise material, objetivo máximo de todo o método de trabalho estatal chamado processo.

\subsection{Conclusões parciais}

Diante de tudo que foi exposto até aqui, algumas conclusões parciais sobre a formulação dos enunciados fáticos e jurídicos, bem como sobre os pedidos, podem ser traçadas.

A primeira delas, partindo-se da visão epistemológica que se adotou, é que os enunciados de fato são fruto de um processo de escolhas adotadas, em geral, pelos advogados das partes, que, de acordo com uma posição subjetiva e interessada, "recorta a realidade" conforme os interesses de seu cliente e em consonância com a tese jurídica por ele estruturada. Ademais, toda essa construção baseia-se em relatos e documentos parciais, o que pode ou ser compatível ou não com a realidade do conflito. Logo, os enunciados fáticos, ao final e a cabo, são parciais, incompletos, fruto de uma construção direcionada dos acontecimentos e potencialmente falsos.

Justamente por essas características, as razões de fato (ou causa de pedir remota) formuladas em um ato introdutório relativas à mesma insatisfação são variáveis de acordo com quem as formula. Em outros termos, os enunciados referentes aos acontecimentos da vida podem ser, se redigidos por um ou outro advogado, distintos entre si ainda que façam menção ao mesmo conflito no plano fenomênico.

É por esse cunho subjetivo e variável dos enunciados de fato que se crê que a definição de causa de pedir seja tão difícil, bem como seja imprecisa a identificação da demanda já com o ato introdutório (consequiência de se usar a causa petendi como elemento identificador trazido nas asserções dos advogados na primeira manifestação 
processual). Como conseqüência lógica, acredita-se, da mesma maneira, equivocada a metodologia de vinculação do instituto da modificação da demanda àquela identificação prévia. Talvez por essa variação e subjetividade da peça introdutória é que os limites do instituto sejam tão nebulosos e sua fixação tão tormentosa entre doutrina e jurisprudência.

Da mesma forma, a estruturação da tese jurídica e a formulação dos enunciados "de direito", que são a roupagem técnica dos fatos dada pelos advogados, não passam de uma interpretação subjetiva e interessada dos acontecimentos feita por cada operador do direito. Nesse sentido, a vestimenta jurídica dos fatos pode, a depender do caso, variar conforme se contrate este ou aquele advogado. A estratégia oscila a depender de quem faz a leitura dos fatos, de sua interpretação, de sua capacidade técnica etc..

Além disso, destaca-se que os patronos dos sujeitos não visam à correta aplicação da lei diante dos acontecimentos a eles apresentados. Ao contrário, buscam convencer o juiz de aplicar as normas mais favoráveis ao seu cliente. Também por essa perspectiva a roupagem de direito atribuída aos eventos são parciais e variáveis, sendo uma imprecisa baliza de identificação de demanda e um conturbado pendão para aplicação do instituto da modificação da demanda.

Por fim, os pedidos de tutela jurisdicional, como se viu, são condicionados pela estrutura jurídica dada à insatisfação dos indivíduos. Se aquelas são variáveis, o mesmo se pode dizer do petitum. Ademais, também conforme exposto, em algumas situações de atecnia ou errônea interpretação dos institutos, eles podem ser formulados equivocadamente, o que não compromete a real natureza do conflito e afasta o caráter absoluto de elemento identificador que muitas vezes a doutrina atribui a eles, demonstrando que também a requisição de tutela é, igualmente aos demais elementos, algo variável e relativa.

Assim, pode-se verificar que todas essas formulações, a despeito de todas essas características, possuem o objetivo de portarem consigo dados e informações relativos a uma insatisfação. Tais conteúdos informativos servirão para que o órgão julgador tome ciência de algo existente fora do processo, ou seja, saia de seu estado epistemológico de conhecimento zero e, evolutivamente, possa compreender o que realmente ocorreu (ou irá ocorrer) e decida com justiça o conflito. 
Os capítulos sucessivos do trabalho, nessa linha, tratarão desse processo evolutivo e da função do instituto modificativo como elemento atribuidor de qualidade à sentença diante do cenário relativo, parcial e subjetivo da fase introdutória. 


\section{A FORMAÇÃO DO JUÍZO E A DEMANDA}

Como foi dito nos capítulos anteriores, o sujeito insatisfeito vem a juízo para pedir uma tutela jurisdicional que atribua a ele o bem da vida capaz de satisfazer suas necessidades. Esse 'pedido', no sentido técnico da palavra, chama-se demanda. ${ }^{266}$

Para que o juiz possa responder se dará ou não a tutela pleiteada, deverá analisar as razões e teses que, segundo o advogado do autor, sustentariam a pretensão trazida a juízo. Ocorre, porém, que, como visto, a demanda é formulada sempre partindo de posições epistemológicas que fazem do ato apenas uma representação parcial, interessada, incompleta e potencialmente falsa da realidade do conflito, além de variável de acordo com as escolhas do sujeito responsável pela sua formulação.

Como é intuitivo, tais características do ato de demandar têm impacto direto sobre a formação do juízo em relação ao problema apresentado e, conseqüentemente, sobre a decisão do órgão julgador. Isso porque qualquer tomada de posição precisa ter diante de si, seja em um âmbito processual ou na vida quotidiana (se se busca, por óbvio, agir coerentemente), um cenário completo e verdadeiro do problema. Caso haja uma incongruência entre a percepção daquele que decide e a realidade fenomênica, há, outrossim, uma enorme possibilidade de que o posicionamento adotado seja equivocado quanto aos padrões decisórios corretos. Os critérios para uma decisão justa serão tratados logo adiante. Porém, parece ser evidente que a correta compreensão dos limites do problema é fundamental para uma tomada de decisão também acertada.

Ademais, é de se destacar que, no tange ao método de trabalho chamado processo, que tem como balizas de funcionamento os chamados princípios da correlação, da ação e dispositivo, o responsável pela decisão possui limitações ulteriores àquelas intrínsecas a todo e qualquer método científico de pesquisa. O juiz, a despeito das limitações da formulação da demanda, não pode buscar a todo custo o conhecimento sobre os reais limites da crise existente no plano concreto. Isso se deve à imposição de restrições por aqueles preceitos principiológicos, fato que tenciona e dificulta ainda mais a relação entre o problema e a sua correta solução.

\footnotetext{
${ }^{266}$ Nesse sentido, com críticas e observações sobre os diversos (e equivocados) sentidos dados à expressão demanda pelo Código de Processo Civil brasileiro de 1973, ver: DinAMARCO, Instituições, II, cit., pp. 109 e ss.
} 
É buscando justamente enfrentar essa problemática relação entre demanda limitada e necessidade de uma sentença justa que o presente tópico se desenvolverá, sempre pautando o trabalho pela visão filosófica e epistemológica, iniciando-se pelo aprofundamento dos requisitos para uma tutela jurisdicional justa.

\subsection{Critérios para uma decisão justa}

Quando se fala em decisão judicial, pensa-se, ainda que indiretamente, em uma decisão fundada em justiça. Um método que visa à solução de crises surgidas no âmago de uma sociedade deve, ao final e a cabo, desaguar em uma sentença que pacifique o conflito com justiça. Pensar, pois, nas decisões do Poder Judiciário não é pensar em qualquer decisão casual ou arbitrária, mas sim fazer referência a um ato decisório formulado segundo padrões justos.

As afirmações feitas acima, a despeito de óbvias, trazem consigo alguns problemas ulteriores que devem ser enfrentados. O primeiro deles é a própria definição da palavra justiça. É possível verificar ao longo do arco histórico filosófico da sociedade ocidental diferenças, por exemplo, entre justiça distributiva e justiça corretiva, substancial e formal, política, social, legal e natural, dentre tantas outras. Dizer que o juiz deverá resolver o caso de maneira justa é algo abstrato e pouco útil, não significando nada em específico - ou significando o que bem entender o interlocutor. Deve-se, pois, em um primeiro momento, preencher a expressão com um sentido que se tomará como premissa do raciocínio.

Ademais, é sabido que inúmeros são os critérios de atribuição de justiça. É possível verificar diferenças, por exemplo, entre a justiça segundo a qual se toma como pendão a necessidade de cada um e aquela justiça que leva em consideração o mérito de cada qual; há diferenças, igualmente, entre os dois critérios citados e aquela justiça que considera os sentimentos dos indivíduos ${ }^{267}$ ou até mesmo um padrão justo segundo crenças divinas ou o estado de caráter dos envolvidos.

Contudo, a despeito da importância filosófica das inúmeras formulações de justiças e seus padrões, ao que tudo indica, nos moldes apontados, não parecem ser os mais

267 Apontando nesse mesmo sentido, TARUFFO, Idee per una teoria della decisione giusta, in Sui Limiti, Bolonha, 2002, p. 219. 
adequados para mesurar se uma decisão judiciária é ou não justa. Seja pela vagueza ou até mesmo pela generalidade, a aplicação desses critérios e conceitos no âmbito de um processo parece ser algo bastante difícil, senão impossível. Não é comum imaginar uma decisão jurídica na qual o juiz atribua um bem a alguém conforme as suas necessidades ou seus méritos, ou então conforme seu caráter ou suas crenças sobrenaturais. Algo mais restrito e seguro deve ser o critério para o cenário processual.

Nesse sentido, é possível afirmar que, no âmbito jurídico em análise, o pendão que atribui justiça a uma decisão é a correta aplicação da lei. Em outros termos, uma sentença será justa se - e somente se - o órgão julgador aplicar corretamente as previsões do direito positivo ao caso concreto. Tais asserções, conforme observa TARUFFO, poderiam ser alvo de críticas no sentido de que consistiriam em uma redução da justiça à lei, bem como de um direito mais amplo ao direito positivo vigente em determinado momento e local ${ }^{268}$. Todavia, ao se afirmar que a lei é um critério de justiça, diferentemente do que possa parecer, não se está, por certo, dizendo que ele é o único e suficiente critério. Ao se adicionar novos elementos, evita-se o reducionismo positivista criticado e podem-se suprir as deficiências das teorias de um legalismo radical ${ }^{269}$. Contudo, parece ser imprescindível que em um cenário jurídico a correta aplicação da lei seja um dos pendões de atribuição de justiça às decisões.

Há na doutrina, outrossim, autores que, pela dificuldade apontada em se identificar critérios que atribuam justiça substancial a uma decisão, criaram um conceito de justiça meramente procedimental ${ }^{270}$. O procedimento justo, segundo eles, seria o único critério para se aferir se uma sentença é ou não justa. Seguindo o itinerário formal à risca, a justiça do ato decisório seria uma conseqüência lógica desse cumprimento das formalidades. Ocorre, entretanto, que tal visão não resolve o problema, mas tão somente o transfere a momentos anteriores ao do ato decisório. Ao invés de definir quais são os critérios para uma decisão justa, perquirem-se, agora, quais são os elementos capazes de definir um

\footnotetext{
${ }^{268}$ Ibidem, p. 220.

${ }^{269}$ Para argumentos favoráveis à equiparação de Direito/Norma, Justiça/Norma, ver KELSEN, Teoria pura do direito, João Baptista Machado (trad.), São Paulo, 1999, passim.

${ }^{270}$ Para aprofundamento, LuHMANN, Legitimação pelo procedimento, Maria da Conceição Côrte-Real (trad.), Brasília, 1980, pp. 53 e ss. Em um cenário atual dos debates doutrinários, essa parece ser a linha adotada, por exemplo, por CORREIA DE MENDONÇA, Virus autoritario e processo civil, in Il Giusto Processo Civile, I, JanMar, 2008, pp. 115 e ss., em específico pp. 120-121.
} 
procedimento como sendo justo. Deve-se, segundo essa visão, fixar os parâmetros de justiça procedimental, isto é, das próprias formalidades a serem observadas.

Ademais, não bastasse a insuficiência apontada, essa visão possui uma notória redução da justiça a um contexto formal, deixando-se de lado o conteúdo verdadeiro e próprio do ato de decidir. ${ }^{271}$

Diante do que foi até aqui exposto, poder-se-ia pensar que a definição de justiça e de seus critérios é algo complicadíssimo, senão impossível, e que não deveria consumir o tempo dos estudiosos, vez que essa é uma empreitada fadada ao fracasso. Não obstante o ceticismo apontado, parte da doutrina se dedicou com afinco ao tema, chegando-se, pelo menos aos olhos de quem escreve, a uma estruturação bastante satisfatória e útil que será usada para o desenvolvimento do presente trabalho ${ }^{272}$. Antes, porém, de definir o que seria decisão justa e quais seriam seus critérios, fundamental tracejar algumas observações que servirão como premissas do raciocínio.

Como foi dito anteriormente, um sujeito insatisfeito traz ao órgão julgador estatal um problema para o qual deseja uma solução. Requer (isto é, demanda) ao Estado um determinado bem da vida que, quer por razões de resistência de outrem ou mesmo de vedação legal, não está em sua esfera de alcance para o seu desfrute. O juiz, diante da crise exposta, pode resolver o caso de inúmeras maneiras; pode, como é facilmente perceptível, dar várias soluções diferentes para o imbróglio.

Tais possibilidades se dão devido às seguintes razões: com o andar procedimental, o juiz poderá comprovar se uma asserção fática feita por um dos envolvidos é ou não verdadeira; se existem ou não provas relativas a uma narração fenomenológica; se a versão A do autor, $\mathrm{B}$ do réu, $\mathrm{C}$ de um terceiro ou ainda $\mathrm{D}$ formulada por ele própria é a que irá prevalecer. Isso significa dizer que sobre cada enunciado fático há pelo menos duas opções de escolha, podendo essa gama aumentar de acordo com a complexidade do fato narrado.

O mesmo fenômeno ocorre quanto à decisão sobre o direito a ser aplicado. Há um enorme leque de normas que poderão ser usadas para aquela situação concreta, bem como outras tantas possibilidades de interpretação da redação normativa eleita pelo julgador. Combinando-se entre si as possibilidades de acertamento de fato e de direito existentes,

${ }^{271}$ Tais observações são de TARUFFO, Idee, cit., p. 221.

${ }^{272} \mathrm{Na}$ doutrina nacional, por todos: RENZO CAVANI, 'Decisão Justa': mero slogan?, in RePro, v. 236, 2014, p. 119 e ss. No cenário internacional, TARUFFO, Idee, cit., p. 219 e ss. 
nota-se que o juiz tem diante de si muito mais que uma única opção para solucionar o conflito.

Destarte, para o presente trabalho, decisão justa é aquela que corresponde, dentre todas as opções existentes, à melhor escolha possível ${ }^{273}$. É bem verdade que a definição retro, se analisada isoladamente, está longe de ser satisfatória. Nota-se que ela não é analiticamente definida, mas intimamente dependente do cenário em que inserida. Em outros termos, a definição proposta não é absoluta, mas relativa às possibilidades existentes dentro do contexto processual concreto. $\mathrm{O}$ número das possibilidades de decisão e a melhor escolha dentre elas, pois, depende umbilicalmente do conjunto de asserções de fato e de direito formuladas no bojo do processo. ${ }^{274}$

Ora, do raciocínio acima exposto, podem-se extrair algumas observações importantíssimas: quanto melhor e mais completa for a formulação da demanda - e também das defesas -, maiores serão as possibilidades de escolha por parte do julgador, aumentando conseqüentemente as condições de se obter a melhor decisão possível e, portanto, mais justa para aquele específico caso concreto. Ocorre, porém, que tanto os atos introdutórios dos autores como as defesas dos réus, em geral, são parciais, interessadas, potencialmente falsas e destinadas à vitória da contenda, tudo devido às posições epistemológicas que cada um apresenta diante da crise e do processo. ${ }^{275}$

Essa relação de tensão, como se verá adiante, pode ser amenizada por meio do instituto da modificação da demanda nos moldes que serão propostos. Tal tema será desenvolvido em sede própria. Por ora, cabe voltar ao objeto do item e tracejar quais seriam então os requisitos para que se possa atingir a decisão com justiça, isto é, quais seriam os padrões que o juiz deverá observar para escolher a melhor decisão para a crise.

O primeiro requisito apresentado pela doutrina é aquele relativo à correção e justeza da escolha e da interpretação do juiz quanto à regra jurídica aplicável ao caso concreto ${ }^{276}$. Parece intuitivo dizer que é inviável apontar como justa uma sentença que se baseia em uma interpretação equivocada dos termos normativos, bem como não se pode conceber

\footnotetext{
${ }^{273}$ Ibidem, p. 223.

${ }^{274}$ Idem, Ibidem.

${ }^{275}$ Para uma análise sobre características da demanda e a decisão justa, ver GAMBA, Domande, cit. pp. 157 e ss.

${ }^{276}$ TARUFFO, Idee, cit., p. 224
} 
sem qualquer inquietação uma decisão calcada sobre uma escolha errônea da regra para a solução de um determinado conflito. ${ }^{277}$

Ocorre, todavia, que a simples escolha correta da norma e sua apropriada interpretação não são suficientes, assim isoladamente, para atribuir justiça à escolha da solução da crise. Basta, por exemplo, pensar em situações nas quais dois ou apenas um desses elementos se fazem presentes, mas a compreensão dos acontecimentos de fato está em desacordo com a realidade. Em casos em que o juiz se equivoca quanto à veracidade ou à falsidade de um acontecimento, há grandes chances de que a escolha da norma aplicável seja também equivocada, pouco importando uma exata interpretação de seus termos. Ademais, como já fora demonstrado no capítulo precedente, uma definição incompleta do dos fatos pode favorecer a criação de um cenário insuficiente para a compreensão dos reais limites da crise e, dentro dessa área restrita e parcial do conflito, a norma mais ajustada para sua solução não seja assim considerada caso houvesse uma ampliação dos fenômenos envolvidos. Basta pensar no exemplo já utilizado da ação de divórcio fundada em convivência insustentável e o adultério superveniente, bem como da gestão temerária da empresa e balancetes extemporaneamente juntados aos autos. ${ }^{278}$

Logo, o segundo requisito fundamental é o acertamento verdadeiro e mais completo possível dos acontecimentos, buscando, nessa linha de pensamento, uma representação fática menos incompleta e mais abrangente dos eventos concretos (lembrando que a completude, por todas as razões narratológicas já expostas, é inalcançável).

Por fim, um terceiro e último requisito é que a decisão deve ser fruto de um procedimento justo, que dê as melhores condições possíveis para que o contexto fático seja completo (ou mais próximo possível da completude), que se possa aferir sua veracidade, bem como possibilite ao julgador escolher a correta norma jurídica ao caso e favoreça sua boa interpretação. É possível pensar que um processo conduzido sem o contraditório compromete a formação do conjunto de enunciados fáticos e de formulações jurídicas, dificulta a produção das provas, compromete a definição completa e verdadeira da representação da realidade, tudo influindo na escolha normativa. Pode-se concluir,

\footnotetext{
${ }^{277}$ Para algumas observações mais aprofundadas sobre alguns padrões de correção da interpretação da lei, em específico quanto à identificação do suporte fático normativo, ver capítulo anterior, item 2.4.1.3. "Os fatos e sua relevância", parte final.

${ }^{278} \mathrm{O}$ tema foi desenvolvido com maior profundidade no item 2.4.1.2. Os fatos e sua complexidade, desse trabalho.
} 
portanto, que também esse requisito deve estar presente para que a sentença seja dotada de justiça.

De tudo que foi dito até aqui, dois pontos parecem ser relevantes: o primeiro é que todos os critérios deverão estar presentes conjuntamente. Somente da combinação dos três é que se poderá formatar um esquema de valoração que possibilite determinar se e quando a decisão é justa ${ }^{279}$. Além disso, nota-se que não são critérios analiticamente definidos, mas se tratam de elementos abstratos e gerais. Todos eles dependem do cenário em que inserido, do caminho e exigências procedimentais específicas do caso, da possibilidade ou não de comprovação dos enunciados etc. Os critérios, tal qual aponta TARUFFO, não são absolutos no sentido de definirem se o ato decisório é justo ou injusto, sim ou não, positivo ou negativo. Ao contrário, são observáveis em escala gradativa, na qual se afere se aquele é o critério mais ou menos justo dentro daquela específica situação processual ${ }^{280}$. A sentença emanada de um processo, nesse sentido, poderá ter sua justiça mesurada em escalas, sendo ela mais ou menos justa, muito ou pouco injusta, sempre se baseando nas possibilidades existentes no caso concreto.

Em uma visão simbólica, o grau de justiça estaria entre dois extremos: a sentença perfeita, fundada na melhor escolha possível dentre todas existentes e imagináveis, e aquela fundada na pior seleção, havendo um espectro infinito de inúmeras outras "medidas" entre esses dois pontos terminais. Para clarear o que se afirmou, algumas considerações adicionais deverão ser traçadas.

Como dito anteriormente, juiz e partes elegem as normas aplicáveis ao caso concreto de acordo com suas posições epistemológicas. Em relação aos litigantes, não se exige que eles façam suas escolhas baseadas na correta aplicação normativa aos fatos; tampouco que eles interpretem os termos legais da melhor maneira possível. Por suas posições diante do conflito, os advogados dos envolvidos escolhem e interpretam a norma de acordo com os interesses de seus clientes. Não devem buscar, conforme abordado alhures, a aplicação justa do direito e a correção de seus termos, mas sim deve revestir o conflito da maneira mais apropriada à tese jurídica estruturada. $\mathrm{O}$ juiz, por seu turno, deverá, diante dos fatos acertados, escolher a norma que entende ser a mais correta para

\footnotetext{
${ }^{279}$ TARUFFO, Idee, cit., p. 224.

${ }^{280}$ Ibidem, pp. 226-227.
} 
aquela determinada situação. A interpretação da lei, não obstante seja variada e múltipla, deverá ser aceitável e de acordo com os institutos jurídicos e as orientações dos tribunais.

Desse modo, diante de um determinado caso, várias poderão ser as normas aplicáveis com aceitação razoável. Será mais justa a sentença em que os conceitos e teorias do direito forem os mais adequados. Da mesma forma, será mais justa a sentença que tiver a interpretação mais coerente. Contudo, algumas das demais decisões possíveis não deixam de apresentar facetas de justiça, portando tão somente um grau menor dessa característica. $^{281}$

A correta decisão, entretanto, depende de fatores extras. Um juiz, sempre que deva julgar um caso posto diante de si, formula antes de emitir o ato decisório um juízo de fato, que consiste em acertar a veracidade dos enunciados sobre os acontecimentos do plano concreto. Sobre as conclusões tiradas após a fase instrutória é que o julgador irá decidir o conflito conforme o direito, isto é, irá escolher e interpretar as normas do ordenamento posto. Há, pois, uma relação de interdependência entre os requisitos apontados. É de se perceber, portanto, que o cenário fático definido condicionará a correta escolha normativa.

A comprovação da verdade ou falsidade das alegações que formam a representação da realidade no processo, como se percebe, é um requisito essencial para o julgamento racional $^{282}$. Ocorre, porém, que para alcançar a verdade dos enunciados deve-se, como é intuitivo, utilizar-se de meios de provas científicos, isto é, de métodos capazes de aferir com validade e confiabilidade se algo ocorreu ou não ${ }^{283}$. Não se pode conceber uma sentença baseada em um juízo de fato extraído de uma leitura da borra de café ou de qualquer resposta sobrenatural sobre a ocorrência ou não das narrações ${ }^{284}$. Sentenças desse

\footnotetext{
${ }^{281}$ É bem verdade que esse conceito de sentença justa traz consigo um problema adicional: até que ponto uma interpretação normativa é ou não aceitável? Qual o limite dessa aceitação e, conseqüentemente, para que uma sentença seja considerada como justa? Tais pontos nebulosos não passaram batidos pela doutrina que se dedicou ao tema. Para aprofundamento, ver TARUFFO, Idee, cit. pp. 227 e ss.

${ }^{282}$ Sobre o conceito de verdade e a decisão da verdade, ver, respectivamente, TARUFFO, La semplice verità, cit. pp. 74 e ss. e 193 e ss.

${ }^{283}$ Para um desenvolvimento do tema da má ciência e da boa ciência em matéria probatória, ver TARUFFO, Prova scientifica (diritto processuale civile), in Enc. Dir., annali II, I, (estratto), pp. 968 e ss.; ID., La prova scientifica nel processo civile, in (estratto) Riv. trim. dir. proc. civ., 2005, pp. 1079 e ss.; CENTONZE, Scienza 'spazzatura' e scienza 'corrotta' nella attestazioni e valutazioni dei consulenti tecnici nel processo penale, in Riv. it. dir. proc. pen., 2001, pp. 1232 e ss.

284 As asserções podem parecer absurdas. Contudo, casos de usos de métodos sobrenaturais podem ser constatados no cenário jurídico internacional. Segundo a mídia, "Gualberto Cusi, magistrado da Corte Constitucional (da Bolívia), revelou a uma emissora de televisão de seu país como resolve casos difíceis. "Quando o caso é complexo, jogo um punhado de folhas de coca em uma manta", explica. Dependendo de
} 
tipo, muito provavelmente, poderiam ser baseadas em falsos enunciados e, como conseqüência, serem injustas.

Entretanto, excluindo-se tais casos extremos, podem-se notar no quotidiano forense métodos mais ou menos confiáveis e técnicos para a aferição da verdade, mas todos considerados idôneos e aceitáveis. Pode-se pensar, por exemplo, no sistema ABO sangüíneo e o exame de DNA para investigação de paternidade. Há décadas, um processo que tivesse o primeiro como método jurídico de aferição da verdade seria considerado o mais adequado e, portanto, a decisão que se fundasse nas conclusões do laudo seria a mais justa. Hoje, porém, a resposta poderia ser diferente ante o cenário tecnológico à disposição do Poder Judiciário.

Além disso, ainda referente à correta definição do cenário fático do conflito, devese ressaltar que a completude de seus limites é algo importante, principalmente se se trata de um caso no qual há fatos complexos. Como se viu, pode-se ter uma decisão que verificou com precisão as asserções contidas no bojo do processo antes da estabilização da demanda. Com o desenvolver do procedimento, novas enunciações poderão ser adicionadas, enunciações essas fundamentais para que o caso seja julgado de maneira diversa. O abandono dessa completude gera uma decisão justa para uma interpretação restritiva do sistema preclusivo, do conceito da causa de pedir e para uma visão liberal desse método de trabalho ${ }^{285}$. Contudo, não é a mais apropriada, segundo a visão aqui adotada, para a solução correta do conflito. Logo, a justiça é, além de gradual, também contextual.

Por fim, pode-se notar que a descoberta da verdade e seus métodos, bem como a conseqüente correção na aplicação da lei, dependem umbilicalmente do procedimento a ser adotado para a resolução da crise. Um rito que não respeita o contraditório e a ampla defesa, por exemplo, dificilmente conseguirá atingir um cenário narrativo próximo do completo. Como conseqüência, a sentença daí originada também poderá não ser justa ou ser menos justa.

como elas caem, revela-se o veredicto. "Na coca, sai!", disse". Notícia acessada em 19.03.2012 em http://m.estadao.com.br/noticias/impresso,a-justica-da-coca-na-bolivia,849944.htm.

${ }^{285}$ Para aprofundamentos sobre a visão liberal e a visão filosófica de processo e seu impacto em matéria de prova dos fatos, ver, para o primeiro, CIPRIANI, L'autoritarismo processuale e le prove documentali, in Il Giusto Processo, I, Jan-Mar, 2007, pp. 289 e ss., e para o segundo, TARUFFO, Poteri probatori delle parti e del giudice in Europa, in Riv. trim. dir. proc. civ., 2006, pp. 451 e ss. 
O procedimento, pois, deverá favorecer o alcance dos outros dois requisitos, sob pena de somente ser possível obter um leque de escolhas de decisão limitado e, nesse sentido, uma justiça da decisão restrita e potencialmente distante daquela ideal em outro cenário procedimental. ${ }^{286}$

No que se refere ao sistema preclusivo ideal e às formalidades que se têm por adequadas, maiores considerações e aprofundamentos serão traçados adiante em sede própria destinada ao instituto da modificação da demanda. Cabe ressaltar aqui, porém, no que tange ao tema do trabalho, que parte da doutrina e da jurisprudência, permeada por uma visão silogística da decisão judicial (muitas vezes, premissa de raciocínio adotada inconscientemente), tem atribuído a alguns princípios, que naturalmente apresentam limitações ao método de pesquisa da verdade, interpretações extremamente restritas e prejudiciais à justiça da decisão, vez que ampliam o formalismo do procedimento e, com isso, comprometem a ampliação da capacidade da reprodução enunciativa dos limites reais da crise. O princípio dispositivo e o da correlação, por exemplo, são tomados por ângulos bastante agudos, trazendo ao processo maiores problemas do que soluções.

Por essa razão, uma revisão desses institutos processuais deverá ser estruturada antes de se prosseguir com o presente estudo, tudo visando a dar a máxima potencialidade ao método para se alcançar os requisitos propostos e a máxima justiça do ato decisório.

\subsection{A visão silogística da decisão}

O presente tópico do trabalho, como se deduz das afirmações feitas no item anterior, se justifica pelo fato de que a teoria da identificação da demanda - aqui tida como clássica ou tradicional - parte de uma premissa que faz uma correspondência direta (ainda que inconsciente) entre os três elementos identificativos (partes, causa de pedir e pedido) $\mathrm{e}$ um modelo silogístico do raciocínio do julgador.

\footnotetext{
${ }^{286}$ No cenário positivo atual, por exemplo, é possível pensar em procedimentos legais não aptos à resolução de casos complexos. Segundo parte da doutrina (por todos, THEODORO JUNIOR, Curso de direito processual civil, III, Rio de Janeiro, 2000, pp. 436), o rito previsto pela Lei 9.099/95 e instituído para solução das ditas pequenas causas, não obstante permita a prova técnica, não comporta a realização da perícia nos moldes previstos pelo CPC. Logo, a parte qualquer debate sobre o tema, o leque de possibilidades de acertamento correto dos fatos diminui bastante, diminuindo, outrossim, as chances de uma correta aplicação e interpretação da lei, bem como de uma sentença mais justa para casos que apresentem maiores complexidades.
} 
Conforme se nota de trabalhos que se destinaram a enfrentar temas processuais que, em regra, são tidos como dependentes de identificação prévia da ação, a demanda refletiria, segundo essa linha de pensamento, a própria estrutura do juízo jurídico ${ }^{287}$. Afirma-se que o procedimento lógico do julgamento da causa possui um conteúdo rígido e meta-positivo inafastável, sendo ele o resultado de uma série de inúmeros outros juízos menores consistentes: a) na verificação de um fato; b) na existência no ordenamento de uma regra idônea a subsumi-lo (busca e primeira interpretação da norma); c) na análise dos efeitos que a lei atribui em abstrato à fattispecie (segunda interpretação da norma); d) nos efeitos atribuídos aos fatos acertados e subsumidos na regra escolhida e interpretada; e e) na observação dos limites referentes a dois ou mais sujeitos. ${ }^{288}$

Havendo o Código de Processo Civil previsto em seu art. $2^{\circ}$ que nenhum juiz prestará a tutela jurisdicional senão quando a parte ou o interessado a requerer, nos casos e forma legais, ou seja, tendo o diploma processual instituído o chamado princípio da ação (ou estabelecendo como base do sistema a inércia da jurisdição), conclui parte da doutrina e da jurisprudência que cabe às partes, mais especificamente ao autor, definir quais são os fatos a serem verificados, a apontar uma norma cabível ao caso concreto, a indicar quais efeitos que a lei atribui à fattispecie normativa, a requerer uma tutela apta a atribuir a ele o bem da vida em disputa, além, claro, de identificar contra quem requer essa tutela. ${ }^{289}$

A corroborar o pensamento descrito, estaria a previsão legal do art. 282 do CPC, que traz o conteúdo mínimo do ato introdutório, exigindo do autor, dentre outras coisas, que exponha o fato e os fundamentos jurídicos do pedido (inciso III), além, é claro, do próprio pedido com as suas especificações (inciso IV). Surge desse raciocínio, pois, a idéia de demanda como projeto de sentença, na qual a estruturação do ato introdutório seria análoga à da decisão. ${ }^{290}$

${ }^{287}$ EDUARDO GRASSO, La regola della corrispondenza tra il chiesto e il pronunciato e la nullità da ultra e da extrapetizione, in Riv. dir. proc., 1965, p. 392.

${ }^{288}$ GRASSO, op.ult.loc.cit.

${ }^{289}$ Idem, Ibidem, que aponta o art. 2.907 do Codice Civile e 99 do Codice di Procedura Civile como fundamentos legais equiparáveis ao art. $2^{\circ}$ do CPC brasileiro.

${ }^{290}$ Nesse sentido, CARnelutTI, Diritto e processo, Napoli, 1958, p. 171. Como se viu, a linha de raciocínio não está de todo equivocada. Ocorre, porém, que as alegações feitas, em geral, são simplificações extremadas do fenômeno de formação do ato introdutório e do processo decisório do juiz. Não se levam em consideração, por exemplo, as posições epistemológicas do sujeito e a natureza restritiva, parcial e potencialmente falsa do ato enunciativo e narratológico. As peculiaridades da formação da inicial e defesa foram tratadas no capítulo anterior. As vicissitudes da atividade judicante será objeto desse capítulo do trabalho. 
Por outro ângulo, essa linha de pensamento tem como fundo o fato de que o autor, responsável pela propositura da ação, apresenta os fatos, as qualificações jurídicas e os pedidos, definindo com isso o objeto litigioso e/ou identificando a sua demanda, o que é imposto ao juiz e à parte contrária. Ao juiz tão somente caberia analisar a existência ou não dos fatos alegados, a subsunção ou não dos acontecimentos acertados à norma proposta, e, ao final, atribuir ou não a tutela pleiteada ${ }^{291}$. Tal atividade seria um processo silogístico mecânico, para o qual as premissas maiores, menores e conclusões já estariam prontas no ato introdutório. $^{292}$

Do que foi dito até aqui, podem-se ressaltar alguns pontos importantes. Em regra, tal pensamento toma como sinônimas - ou com conteúdo bastante próximo - três expressões: princípio dispositivo, inércia da jurisdição e princípio da ação. A vedação à atribuição de tutela pelo judiciário sem requerimento da parte interessada é ampliado aos demais "elementos objetivos identificadores", tudo por acreditar, pautados por uma premissa silogística, que a estrutura da demanda é igual à da decisão. Surge o conceito alargado de princípio da correspondência entre a demanda e o juízo, intimamente ligado ao princípio dispositivo, equiparado (ou confundível) com a inércia jurisdicional inicial.

A doutrina tradicional, em outros termos, baseando-se no fato de que a demanda identificada pelos seus três elementos - deve ser proposta pelo interessado, afirma que a causa de pedir e o pedido de tutela jurisdicional, todos componentes em maior ou menor escala do objeto litigioso (algo disponível e pertencente à parte), sejam exclusividade do autor pelo dito princípio dispositivo. Não podendo o juiz julgar além, fora ou aquém do que fora demandado, devendo respeitar os limites da ação, pautando-se por uma premissa silogística da aplicação do direito, em que a estrutura da demanda e do raciocínio da formação da decisão judicial são iguais, estende-se a inércia jurisdicional à análise dos fatos, fundamentos jurídicos e pedidos. Aprofundamentos quanto aos elementos principiológicos, seus limites e suas extensões, serão tratados em tópico futuro. Para o

\footnotetext{
${ }^{291}$ Em exposição sobre a delimitação do objeto litigioso e sua vinculação no âmbito do processo penal, ANDRES DE LA OLIVA SANTOS assim afirma: "Destacan por su importancia intrínseca y por su relevancia en cuanto a la vinculación los seguientes puntos: el hecho objeto de acusación, la persona de los acusados y la calificación jurídica formulada por los acusadores, a la que se anuda una concreta petición de pena o penas", Disponibilidad del objeto, conformidad del imputado y vinculación del Tribunal a las pretenciones em el proceso penal, in (estrato) Revista General de Derecho, Out-Nov, 1992, p. 9861.

292 Analisando criticamente essa relação, GAMBA, Domande senza risposta, cit., p. 36 e 37.
} 
momento, entretanto, cabem algumas críticas quanto à premissa silogística desse raciocínio.

Quanto ao ponto, é de se destacar que somente dentro de um silogismo se pode aceitar que as premissas maiores e menores estejam prontas, acabadas e analiticamente definidas no ato introdutório. Somente em uma linha de raciocínio em que a decisão judiciária consiste na mera verificação automática da aplicação ou não de normas sugeridas pelo autor aos fatos por ele alegados é que se pode ter como perfeitos e acabados os elementos da petição inicial. Mais do que isso: é somente pensando silogisticamente que a causa de pedir e pedido, bem como o cenário fático e jurídico sobre os quais o juiz poderá se manifestar, possui um caráter rígido e delimitado já na primeira manifestação das partes.

Ocorre, todavia, que é justamente essa a grande crítica recebida pela escola silogística do direito. Tal modelo, como é reconhecido até mesmo pelos seus seguidores, realiza uma simplificação distante da realidade, fazendo-se uma síntese extremada de um complexo processo de raciocínio do juiz. Alguns autores, assumindo a incapacidade do modelo proposto, configuraram entorno do 'silogismo final' uma cadeia de 'silogismos instrumentais' (Hilfsyllogismen), sendo aquele o resultado desses. ${ }^{293}$

Não obstante as várias correntes silogísticas existentes, observa-se que o modelo de juízo se mantém sempre com o mesmo módulo lógico-estrutural, variando tão somente de um mero silogismo a um poli-silogismo concatenado. ${ }^{294}$

Tal visão, como não poderia deixar de ser, sofreu intensas críticas fundadas em duas grandes linhas de argumentos: a da falsidade e a da falta de completude da teoria silogística.

A falsidade da representação consistiria, em suma, em afirmar que a atividade decisória do juiz não apresenta uma natureza lógico-racional. Essa negação originou as diversas teorias chamadas irracionalistas ${ }^{295}$, que puseram luz sobre elementos do processo decisório que não se encontram nessa estrutura. Contudo, o fato de que o silogismo não

${ }^{293}$ RosenBERG-SCHWAB, Zivilprozessrecht, Munique, 1969, p. 686, apud TARUFFO, La motivación, cit. p. 152.

294 Tais observações são de TARUFFO, op.ult.loc.cit.

295 Várias podem ser as linhas irracionalistas. Para um apontamento com bibliografia extensa sobre o irracionalismo psicológico, irracionalismo filosófico-axiológico e anti-racionalismo, ver TARUFFO, ibidem, pp. 106-109. 
contempla fenômenos psíquicos, epistemológicos e filosóficos do raciocínio judicial não faz dele algo imprestável e sem qualquer validade.

Reconhecendo traços de utilidade - ainda que reduzidos - da escola silogística, parte dos estudiosos passou a interpretá-la apenas como incompleta, e não falsa. Afirmouse que o silogismo pecava por não conseguir expressar a atividade criativa do juiz, mas tão somente sua estrutura formal do raciocínio. Disse-se, em outra vertente, que o modelo criticado não levava em conta os traços voluntaristas da decisão, mas apenas os cognoscíveis. $^{296}$

Nessa linhagem de análise, chegou-se à tese de que o silogismo judicial não alcançava em sua representação todo o processo do juízo, mas representa apenas "el iter que sigue el juez para deducir la decisión a partir de las premissas de hecho y de derecho, pero no comprende la actividad esencial con la cual el juez llega a fijar dichas premisas,"297.

Para o objeto do presente trabalho, ressalta-se que as críticas à escola silogística expuseram à luz um problema bastante importante, mas olvidado por parte dos estudiosos: as premissas maiores e menores, isto é, as premissas de fato e de direito que fundamentam a decisão não estão prontas e acabadas com a demanda, não sendo a atividade do órgão julgador restrita a realizar o encaixe dos acontecimentos à fattispecie normativa e dela extrair suas consequiências jurídicas. Ao contrário, tais premissas deverão ser construídas ao longo do processo. Cabe destacar aqui, nesse sentido, que o caráter estático dado pelo fundo silogístico, que ampara a teoria da identificação da demanda e a rigidez dos requisitos da inicial, cai por terra, ganhando a ação um caráter dinâmico compatível com a realidade processual.

A dinamicidade apontada é uma característica intrínseca ao processo decisório. Enclausurar a área de cognição do juiz - frise-se, por erro de perspectiva ou de premissa, como se acredita ser - no ato introdutório e nas manifestações iniciais dos envolvidos, atribuindo à demanda um caráter estático e rígido, é um fator de equívoco em grande parte dos estudos.

\footnotetext{
${ }^{296}$ Expressando-se assim, FAZZALARI, La giurisdizione volontari - Profilo sistemático. Padua, 1953, pp. 134 e ss.

${ }^{297}$ TARUFFO, La motivación, cit., p. 154.
} 
A criação das premissas de fato e de direito pelo julgador, momento fundamental do processo decisório, é algo intrinsecamente dinâmico, como se verá especificamente no tópico subseqüente. Enrijecê-lo, pois, tal como ocorre com o silogismo, faz com que as premissas sejam potencialmente deficientes e, como se viu, cause a injustiça da decisão. Tais temas serão abordados adiante. Porém, nesse momento, essencial será tracejar algumas linhas mais destacadas no que tange à construção do juízo de fato e de direito por parte do órgão julgador.

\subsection{O juízo de fato}

O tópico precedente do trabalho buscou demonstrar como não é (ou, como expressamente se posicionou, como é em parte) a estrutura do raciocínio do juiz e a aplicação da lei ao caso concreto. Cabe, nesse momento, pois, por uma perspectiva positiva, demonstrar como, então, se dá a formação do convencimento do órgão julgador, a construção das premissas de fato e de direito, bem como a extração das conseqüências jurídicas (único momento silogístico de todo o fenômeno) por parte de quem julga.

Como fora dito no item anterior, a teoria silogística não representa por inteiro o complexo processo decisório do juiz e a aplicação do direito ao conflito posto à resolução. Ao contrário disso, o silogismo é apenas o iter que ele segue para deduzir a decisão após as fixações das premissas maiores e menores. É, portanto, apenas um pequeno momento daquela atividade decisória. Assim sendo, mister será identificar, ainda que superficialmente e sem pretensão de exaurir o tema, como o julgador faz seu juízo de fato e escolhe as normas a serem aplicadas, isto é, como ele constrói as premissas a serem usadas para se chegar a essa decisão.

Antes de adentrar propriamente no tema proposto, algumas conceituações deverão ser aprofundadas a fim de que os termos possam ter seus significados definidos.

A palavra juízo, segundo se nota no quotidiano forense, é utilizada em pelo menos duas acepções distintas, porém relacionadas. A primeira delas é como sinônimo de processo, tal como em 'juízo de primeiro grau', 'levar algo a juízo', dentre outras. A segunda, e esse é o sentido que terá mais relevância para o desenvolvimento do trabalho, é 
o uso da expressão equivalente a decisão, a julgamento. É o que se extrai de 'juízo de fato', ‘juízo de direito', 'pronúncia do juízo’ etc.

Embora distintos entre si, em artigo dedicado especificamente a esse tema, TARUFFO aponta que o uso do termo com significado bifronte não é casual, mas conseqüência da relação de instrumentalidade existente entre o método (processo) e a decisão (sentença), isto é, devido ao liame de meio e fim que une os dois significados. ${ }^{298}$

No que tange à equiparação semântica de juízo à decisão, alguns esclarecimentos ulteriores deverão ser feitos. É comum verificar no linguajar do foro um intercâmbio das expressões 'julgar' e 'decidir'. Ocorre, porém, conforme aponta a doutrina especializada, que juízo, se analisado mais profundamente, equivale a um dos métodos usados para se atingir uma decisão, e não à decisão verdadeira e própria. O juízo, pois, constitui o processo de construção da decisão. Em outros termos, juízo é um procedimento com o qual "viene posta in essere l'attività del decidere, mentre la decisione in senso stretto ne costituisce il risultato finale". ${ }^{299}$

A diferenciação ganha relevo se considerado o fato de que cada juízo (decisioneattività) implica escolhas dentre as várias alternativas de decisões existentes (decisionerisultato $)^{300}$. Escolher significa individualizar a opção mais apropriada segundo parâmetros definidos. Juízo de fato e de juízo direito dentro de um cenário processual, pois, são métodos de escolha por parte do juiz dos enunciados fáticos e das regras jurídicas dentro de um espaço amostral existente que estarão na base da decisão.

Se é verdade que toda decisão pressupõe uma escolha, não se pode dizer que toda decisão é fundada em um juízo. Há decisões que, não obstante seja a individualização de uma das possibilidades existentes (escolha), são tomadas por métodos que não envolvem um juízo na acepção aqui adotada. Jogar um dado para verificar qual dos jogadores será o que irá iniciar uma partida, por exemplo, não é um método que envolva qualquer tipo de juízo, mas há aí, como é fácil notar, uma escolha, uma decisão.

\footnotetext{
${ }^{298}$ Giudizio: processo, decisione, in Sui Confini, Bolonha, 2002, p. 157 e ss. Para aprofundamentos quanto a essa relação de instrumentalidade na doutrina nacional, ver, com maestria, DINAMARCO, Instrumentalidade do processo, cit, passim, e BEDAQUE, Direito e processo, cit., passim.

299 TARUFFO, Giudizio, cit. p. 167.

${ }^{300}$ A nomenclatura elucidativa e auto-explicativa entre parênteses é de TARUFFO, ibidem, que também usa decision-making para se referir ao juízo.
} 
É justamente enfrentar as vicissitudes desse método de valorações e escolhas que o presente tópico se destina.

E, para iniciar esse intento, retomar-se-ão alguns conceitos e elementos já referidos anteriormente. Como foi dito, as partes do processo, em suas manifestações iniciais, formulam enunciados sobre os fatos e acontecimentos que compõem a crise. Tais enunciados possuem inicialmente um estado epistemológico de incerteza, típico das hipóteses que ainda não foram verificadas ${ }^{301}$. Tais enunciados, como várias vezes se disse aqui, são construídos de maneira parcial e interessada, além de serem incompletos. ${ }^{302}$

As enunciações das partes vertem sobre fatos principais e fatos secundários, bem como sobre fatos irrelevantes, tudo estruturado segundo a estratégia e a tese jurídica definida por seus advogados.

No que tange à atividade desses sujeitos, algumas observações ulteriores devem ser traçadas. Tal qual fora dito no capítulo anterior, as partes formulam seus enunciados fáticos partindo de posições epistemológicas contrapostas. Contudo, tanto o autor como o réu descrevem a realidade de pontos de vistas envolvidos, 'recortando' os fenômenos por uma perspectiva que lhes interessam (partidarismo) e 'escondendo' eventos que não favorecem a tese de defesa de seus interesses (incompletude).

A versão inicial do autor induz um comportamento específico de defesa do réu. A manifestação do réu, por seu turno, provoca uma reação comportamental no autor ${ }^{303}$. Instaura-se com isso, pois, um jogo dialético entre as partes, sempre fundado em enunciações de fatos e teses jurídicas aptas a defender os interesses de cada qual e a contrastar com as de seu adversário. Esses conjuntos de enunciações contrapostas se desenvolvem dinamicamente com o evoluir procedimental e são movidos a cada manifestação apresentada. ${ }^{304}$

Além da atividade narrativa exercida pelas partes, o juiz também formula enunciados sobre os acontecimentos. É bem verdade que o sistema processual civil, por meio de alguns dispositivos, restringe a atividade enunciativa do julgador. Ele não pode

${ }^{301}$ TARUFFO, Elementi per un'analisi del giudizio di fatto, cit. p. 239.

${ }^{302}$ Maiores aprofundamentos sobre tais características, ver capítulo 2.

${ }^{303}$ Os termos autor e réu são usados no texto de maneira elíptica. Deve-se entender, pois, advogado do réu e advogado do autor. As implicações práticas desse esclarecimento podem ser vistas no capítulo precedente.

304 TARUFFO, Elementi, cit. pp. 242-243. Tal indução gera, muitas vezes, a necessidade de modificação da própria enunciação. Nesse sentido, ID., Giudizio, cit. pp. 164-165. 
livremente narrar acontecimentos que não foram objeto de descrição pelas partes (art. 128, CPC), salvo algumas poucas exceções ${ }^{305}$. Todavia, pode formular enunciados diversos daqueles confeccionados pelas partes referentes a fatos por elas aportados. Tal atividade ativa do julgador provoca, igualmente, reações e influi no comportamento dos demais envolvidos, colaborando para a dinamicidade da construção do conjunto representativo da crise.

Desse modo, vê-se que os três sujeitos protagonistas do processo ${ }^{306}$, como é facilmente perceptível, desenvolvem uma atividade consistente em enunciar acontecimentos do plano fenomênico possivelmente relevantes para a decisão final. ${ }^{307}$

Não bastassem as partes e o juiz, formulam enunciados, outrossim, os ditos agentes secundários do cenário processual. Testemunhas, peritos, eventuais terceiros envolvidos, membros do ministério público, dentre outros, também são responsáveis por narrar eventos e por formular enunciados sobre fatos da crise.

Todo esse conjunto de enunciados, com todas as características epistemológicas já apontadas, compõe o objeto do juízo fático. ${ }^{308}$

Para uma visualização do que aqui se expõe, buscar-se-á traçar uma estrutura representativa desse objeto.

O autor (rectius: seu advogado) traz em com a petição inicial uma tese jurídica destinada a defender seus interesses. Nela, há uma apresentação de fatos que, segundo a

\footnotetext{
${ }^{305} \mathrm{O}$ tema das matérias cognoscíveis de ofício é bastante controverso. Para uma análise geral, sem pretensão de exaurimento, ver ID., L'integrazione dell'art. 101 C.P.C., il contraddittorio sulle questioni rilevate d'ufficio e la 'scommessa aperta' dell'ordinamento processuale, in TARUFFO (diretto da), Il processo riformato, Bologna, 2010, pp. 65-179, em especial pp. 71-87; CHIARLONI, Questioni rilevabili d'ufficio, diritto di difesa e 'formalismo delle garanzie', in Riv. trim. dir. proc. civ., 1987, p. 569 e ss.; CIVININI, Poteri del giudice e delle parti, cit., pp. 1 e ss.; CORSINI, Rilevabilità di ufficio della nullità contrattuale, principio della domanda e poteri del giudice, in Riv. dir. civ., 2004, pp. 667 e ss.; DENTI, Questioni rilevabili d'ufficio e contraddittorio, in Riv. dir. proc., 1968, pp. 217 e ss.; GRASSO, La pronuncia d'ufficio, Milano, 1967, pp. 43 e ss.; LUISO, Questione rilevata di ufficio e contraddittorio: uma sentenza 'rivoluzionaria'?, in Giust. civ., 2002, pp. 1612-1615. Para algumas apreciações críticas sobre a rigidez do CPC brasileiro, CELSO AGRÍCOLA BARBI, Comentários ao Código de Processo Civil, Rio de Janeiro, 1975, em específico pp. 524-525.

306 Como nota TARUFFO, Elementi, cit., pp. 240-241, essa é uma estrutura simplificada da estrutura do processo. Pode-se tranquilamente pensar em uma situação que envolva vários autores, vários réus e, por que não, vários juízes, como no trier of facts, todos formulando seus enunciados e construindo suas representações das realidades fáticas, aumentando, pois, a área de abrangência do objeto do juízo de fato.

${ }^{307}$ Idem, Ibidem.

${ }^{308} \mathrm{O}$ direito positivo brasileiro é expresso em autorizar o juiz a considerar todos enunciados de fatos contidos no processo, mesmo que não oriundos das atividades das partes. O art. 131 do CPC dispõe que "o juiz apreciará livremente a prova, atendendo aos fatos e circunstâncias constantes dos autos, ainda que não alegados pelas partes". Logo, todos os enunciados comporão o conjunto objeto do juízo.
} 
estrutura jurídica escolhida, são principais (que aqui serão representados por FP) e outros que são secundários $(f s)^{309}$. Dentro dos enunciados relativos aos fatos principais, podem-se distinguir aqueles tidos por constitutivos da demanda (FD) - em regra, aportados pelo autor - e aqueles chamados extintivos, modificativos e impeditivos do direito pleiteado (FE) - geralmente aportados pelo réu. ${ }^{310}$

Esquematicamente, quanto aos fatos, o ato introdutório pode ser assim representado $^{311}$ :

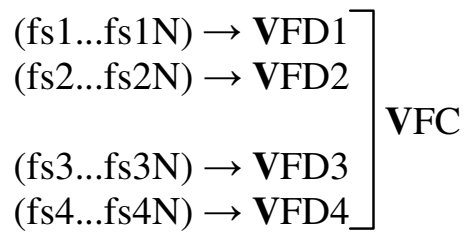

Após a citação, poderá o réu apresentar uma série de defesas, que podem ser diretas ou indiretas. Levando em consideração que houve contestação ao mérito - que é o que realmente interessa ao trabalho -, por meio da peça de defesa poderá ele negar os fatos constitutivos (FFD); negar um, alguns ou todos os fatos secundários (F(fs...fsN)) dos quais se poderia inferir a veracidade de um FD; aportar novos fatos secundários, que, por inferência, demonstram a falsidade de FD; ou, ainda, apresentar fatos principais (FE).

A representação do conjunto enunciativo pós-contestação seria, em síntese, $\operatorname{assim}^{312}$ :

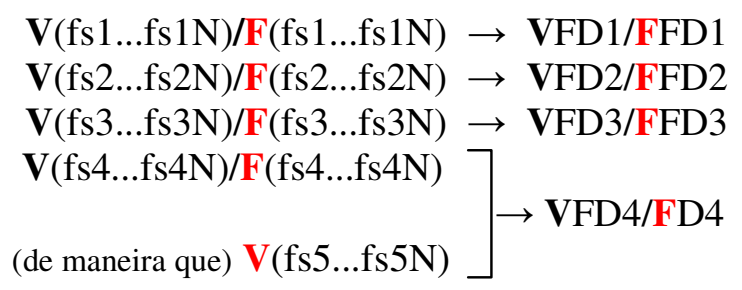

\footnotetext{
${ }^{309}$ Assim como os fatos principais podem ser inúmeros, os fatos secundários e sua relação com o respectivo principal podem variar de 1 a $\mathrm{N}$.

${ }^{310}$ Para aprofundamentos quanto ao momento de formação dos enunciados, suas classificações, bem como suas variabilidades de importância ao longo do processo, ver capítulo 2, especificamente o item 2.4.1.3. Os fatos e sua relevância.

${ }^{311}$ Toda a esquematização aqui reproduzida é proposta por TARUFFO, Elementi, cit. pp. 245 e ss.

312 Com intuito de facilitar a visualização, colocou-se em vermelho aquilo que fora enunciado pelo réu, mantendo-se em preto os enunciados do autor e, mais adiante, violeta para enunciações do juiz.
} 
No esquema acima, o réu, como é perceptível, impugnou, direta ou indiretamente, todas as alegações fáticas do autor. Entretanto, como é comum na prática forense, pode ser que, mesmo depois da apresentação da peça de defesa, enunciados autorais restem incólumes. Segundo o art. 334, inciso III, do CPC, tais enunciados, por conseqüência legal, deveriam ser tomados como verdadeiros independentemente de provas, não compondo, portanto, o conjunto objeto do juízo fático. Entretanto, cabe aqui ressaltar, sem pretensão de aprofundamento do debate - o que fugiria aos limites do presente trabalho-, que parte da doutrina defende que mesmo que não impugnados alguns fatos poderão ser objeto de prova $^{313}$. Nesses casos, o enunciado não impugnado comporia o objeto e seria passível de juízo.

Por meio da contestação, igualmente, podem ser inseridos no contexto do processo, como se disse, enunciados sobre fatos extintivos, modificativos ou impeditivos, genericamente tidos FE. Logo, se há o aporte de enunciados de fatos dessas naturezas, então se adiciona ao esquema acima a seguinte estrutura:

$$
\begin{aligned}
& \text { VFE1 } \\
& \text { V(fs6...fs6N) } \rightarrow \text { VFE2 } \\
& \text { V(fs7...fs7N) } \rightarrow \text { VFE3 }
\end{aligned}
$$

Além dos comportamentos defensivos acima descritos por parte do réu, pode ele ainda contra-atacar. Nesse sentido, também ele enuncia fatos constitutivos reconvencionais (FDR), reveste-os com roupagem jurídica a ponto de estruturar uma tese em defesa de seus interesses, além de formular pretensões. Nessa situação, além dos esquemas 2 e 3, soma-se ao conjunto enunciativo objeto de juízo a seguinte representação:

$$
\left(\text { fs8...fs8N) } \rightarrow \begin{array}{r}
\text { VFDR1 } \\
\text { VFDR2 }
\end{array}\right.
$$

Da mesma maneira que ocorre com a inicial, o autor-reconvindo, em resposta, pode negar os fatos constitutivos reconvencionais, negar um, alguns ou todos os fatos secundários, trazer fatos secundários dos quais se infere a falsidade de um fato constitutivo, além de poder aportar fatos impeditivos, extintivos ou modificativos do direito do reconvinte (FER). O esquema da reconvenção pós-resposta, pois, será:

${ }^{313}$ Com ampla referência à doutrina e à jurisprudência italianas, FABIO ROTA, I fatti non contestati e il nuovo art. 115, in TARUFFO (diretto da), Il processo civile riformato, Bolonha, 2014, pp. 183 e ss; TARUFFO, Elementi, cit. p. 258. 


\section{VFER1 \\ VFDR1/FFDR1 \\ $\mathrm{V}(\mathrm{fs} 8 \ldots \mathrm{fs} 8 \mathrm{~N}) / \mathrm{F}(\mathrm{fs} 8 \ldots \mathrm{fs} 8 \mathrm{~N}) \rightarrow$ VFRD2/FFDR2}

O conjunto de enunciados fáticos, somando-se a demanda e a reconvenção, ambas já submetidas ao contraditório, mais eventual réplica apresentada à contestação, poderia ser representado pelo seguinte esquema:

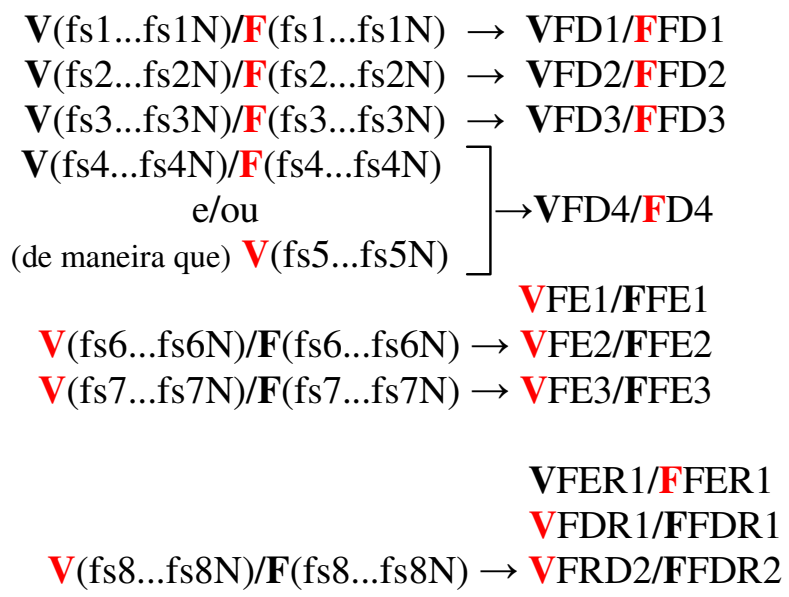

Como foi dito, o juiz também pode formular enunciados sobre fatos cognoscíveis de ofício (FCO). Independentemente do limite desse poder, fato é que o contraditório é também dirigido, conforme tem defendido grande parte da doutrina, ao juiz, que deve submeter tais questões à manifestação das partes ${ }^{314}$. Nesse caso, poder-se-ia adicionar ao até aqui proposto a seguinte estrutura representativa:

$$
\mathrm{V}(\mathrm{fs} 9 \ldots \mathrm{fs} 9 \mathrm{~N}) / \mathrm{F}(\mathrm{fs} 9 \ldots \mathrm{fs} 9 \mathrm{~N}) \rightarrow \mathrm{VFCO} 1 / \mathbf{F F C O} 1
$$

Todo o conjunto apresentado traz, tão logo esteja formado, um grau epistemológico de conhecimento igual a zero, ou, em outras palavras, encontra-se em um estado de ignorância cognitiva ${ }^{315}$. É nesse momento que as partes, bem como o juiz ${ }^{316}$, deduzem

\footnotetext{
${ }^{314}$ Para uma interessante análise sobre a bidirecionalidade do princípio, ver DINAMARCO, O Princípio do Contraditório e sua Dupla Destinação, in Fundamentos do Processo Civil Moderno, v. I, São Paulo, 2010, pp. 520 e ss.

315 TARUFFO, Elementi, cit., p. 252. Para aprofundamentos quanto aos modelos de estados epistêmicos, GÄRDENFORS, Knowledge in flux, cit., pp. 21 e ss.
} 
meios de provas para acertar a veracidade ou falsidade dos enunciados componentes do conjunto representado.

Quanto ao ponto, importante notar que também no momento em que as partes apontam os meios de prova, há a possibilidade de adição de novos enunciados ao conjunto já existente. Isso por que algumas provas dependem de uma exposição prévia quanto a sua credibilidade ou sua autenticidade. Assim, havendo uma testemunha, pode um dos sujeitos formular novas enunciações de fatos quanto, por exemplo, suas relações com a contra-parte ou o juiz. Um perito pode ser questionado quanto a sua capacidade técnica. A veracidade de um documento pode ser contestada. Surgem, assim, novos fatos secundários subsidiários $(f s s)$. Tais fatos também constituirão objeto de acertamento por parte do julgador. $^{317}$

Do que fora dito até aqui, alguns pontos parecem ganhar destaque. O primeiro deles é que todos os agentes processuais, protagonistas ou secundários, formulam enunciados sobre fatos. Cada enunciado tem um impacto no comportamento nos demais, inclusive - e principalmente - no do autor, do réu e do juiz, que reagem de acordo com suas posições epistêmicas diante da crise apresentada. Esse efeito de ação e reação implica em um sistema dinâmico do método de trabalho estatal de resolução de conflito, em específico no que tange ao objeto do juízo de fato.

Nesse sentido, sabendo que um novo enunciado fático pode ser aportado ao processo na fase postulatória, mas também em fases sucessivas como a instrutória e até mesmo a decisória, conclui-se que a todo o momento uma condição processual pode surgir e que anseie uma alteração/complementação do conjunto enunciativo que compõe o objeto do juízo de fato. A formação de seus limites, como se viu, não é algo estático e analiticamente definido pelas partes no ato introdutório e de defesa, mas vai se formando gradativamente, com avanços e retrocessos, até o momento final da decisão.

Outro ponto importante é que é comum que a doutrina estude a aquisição da prova dos enunciados de fato fazendo menção às suas modalidades procedimentais, ou até mesmo sobre os meios de prova em si. Como observa TARUFFO, essa perspectiva de

\footnotetext{
${ }^{316}$ Muito se debate sobre os poderes instrutórios do juiz. Não obstante a concordância do autor do texto com a vertente autorizativa do comportamento ativo do magistrado (por todos, BEDAQUE, Poderes Instrutórios do Juiz. São Paulo: Revista dos Tribunais, 2009, passim), fato é que, ao menos em relação aos enunciados fáticos relativos à matéria cognoscível de ofício, o juiz deverá apontar os meios de prova cabíveis.

${ }^{317}$ TARUFFO, Elementi, cit. p. 253.
} 
análise parte de uma premissa implícita na qual as provas são acumuladas progressivamente, formando um conjunto de informações que serão analisadas e valoradas pelo juiz tão somente no momento final de decisão do caso concreto. ${ }^{318}$

Todavia, tal percepção 'suspensiva' das informações oriundas dos meios de prova parece, aos olhos de quem escreve, equivocada. Mais próximo da realidade parece ser a estruturação teórica que se baseia na idéia de que durante a aquisição dos elementos de prova o juiz varia de um estado epistêmico a outro. Ao adquirir novos elementos de consciência, ele sai de um estado perceptivo em relação aos fatos e alcança outro patamar diferente.

Acontece, entretanto, que essa evolução não se dá de forma linear e crescente, mas segue um itinerário de integração e revisão, marchas e contramarchas, com uma série de modificações, para frente e para trás, dos convencimentos provisórios que possuía no estado epistêmico anterior ${ }^{319}$. Logo, qualquer representação que aponte para uma rigidez de premissas maiores e menores configura tão só uma grande simplificação, deixando de lado toda a complexidade da suas construções, gerando mais problemas que soluções.

Ao final de todo esse complexo processo, o juiz terá uma percepção com consciência dos verdadeiros e dos falsos enunciados sobre os fatos. Ali, poderá avaliar o que realmente aconteceu e formular a sua versão definitiva dos acontecimentos.

Definido o objeto do juízo de fato e feitas observações quanto ao seu resultado, cabe nesse momento, portanto, aprofundar as considerações sobre essa teoria dos estados epistêmicos e do fluxo do conhecimento, dando uma visão mais completa dessa evolução.

\subsubsection{Knowledge in flux e a formação da premissa de fato}

Mostrou-se no item anterior uma sintética representação do que seria o conjunto de enunciações objeto do juízo de fato. Nesse momento, entretanto, buscar-se-á fazer um pequeno estudo sobre como esse juízo, em teoria, se dá. Para tanto, usar-se-ão conceitos de

\footnotetext{
${ }^{318}$ TARUFFO, ibidem, p. 256. Mas uma vez se nota reflexos de um raciocínio silogístico no tema do juízo.

${ }^{319}$ Essa é a lógica evolucional do convencimento em todas as áreas da pesquisa. Não só no direito e no processo, mas em qualquer segmento do conhecimento, a substituição, a modificação, o retrocesso e o avanço nos estados de convencimento do pesquisador são algo fundamental para a conclusão.
} 
epistemologia geral, que demonstrarão como a teoria dos fluxos de conhecimento pode ajudar a compreender a dinâmica processual na formação das premissas fáticas do julgamento por parte do juiz.

Para iniciar, importante destacar que qualquer idéia que envolva fluxo pressupõe um ponto de partida. Na teoria dos fluxos do conhecimento, esse ponto assume o caráter de um estado de conhecimento inicial, que, no processo, levando-se em consideração que se trata do juiz, é zero.

Com a introdução da demanda, o autor formula suas narrações fáticas trazendo ao magistrado contornos parciais e incompletos da crise que deseja resolver. Esses enunciados são, outrossim, potencialmente falsos. Desse modo, se analisadas assim isoladamente, tais enunciações justamente por serem hipotéticas e aponfânticas, não possuem qualquer elemento de conhecimento, mantendo-se o estado inicial de na ignorância cognitiva. O julgador, após a leitura da inicial, embora se mantenha sem qualquer grau de cognição, terá somente uma percepção dos limites do conflito, percepção essa que possui o mesmo caráter provisório, hipotético e potencialmente falso das narrações autorais. ${ }^{320}$

Na seqüência, o réu apresenta sua contestação e, eventualmente, sua reconvenção. Segundo se pode notar no item precedente, várias são as maneiras de configuração da representação dos enunciados fáticos após a sua manifestação. Contudo, independentemente da estratégia de defesa e contra-ataque adotada, fato é que também ele, réu, formula suas enunciações de maneira parcial, incompleta e potencialmente falsas. Também aqui não há qualquer inserção de elementos de consciência, mas tão somente de percepção. $^{321}$

O conjunto de asserções e enunciações de fato formado pelo autor, pelo réu e, por vezes, pelo próprio juiz logo após a apresentação da inicial, contestação, eventual reconvenção e réplica, é formado por elementos que apresentam caráter meramente hipotético. Os enunciados, como dito anteriormente, são apofânticos, passíveis de

\footnotetext{
${ }^{320}$ É bem verdade que a inicial poderá vir instruída com documentos e meios de prova pré-constituídos. Nesse caso, mais do que mera percepção, o juiz, se tiver contato com eles, possuirá um grau de crença diferente de zero, ainda que mínimo. Para uma análise sobre os conceitos de perception, bilief e Knowledge, DRETSKE, Knowledge and the Flow of Information, Cambridge, Mass., 1981, pp. 54 e ss.

321 Observa TARUFFO que mesmo que não haja impugnação de um enunciado, ou seja, que uma das enunciações reste incontroversa, a hipótese não contém em si qualquer elemento de verdade, não oferecendo ao juiz, pois, qualquer ingrediente de conhecimento, ainda que a lei lhe atribua presunção de varacidade. Nesse sentido, Elementi, cit. p. 258.
} 
comprovação se verdadeiros ou falsos. Logo, há aí uma manutenção do estado de ignorância cognitiva total por parte do juiz até esse momento procedimental.

São os meios de prova que irão introduzir elementos de conhecimento no processo. Para a teoria do fluxo do conhecimento aplicada ao cenário jurídico, são elas os Epistemic Inputs responsáveis por desestabilizar o estado epistêmico inicial e levar o destinatário a um estado posterior diferente ${ }^{322}$. Da ignorância cognitiva plena, passa-se a um convencimento possivelmente não errôneo (error free beliefs) fundado na aquisição de uma prova sobre uma determinada enunciação de fato. O juiz sai de uma mera percepção e passa a um estado de crença.

Importante destacar que a teoria em questão não faz uma abrangência geral do conhecimento do julgador e sua evolução. Ao contrário, refere-se a cada enunciado fático individualizado $^{323}$. Desse modo, cada input epistêmico adicionado altera o estado inicial de conhecimento referente àquele fato (rectius: enunciado sobre o fato).

Os inputs, em regra, não se apresentam no cenário de pesquisa simultaneamente. No processo, os elementos de conhecimento são aportados em diversos momentos, nas mais variadas fases do procedimento. Nesse sentido, cada input causa uma modificação no estado anterior determinando um novo estado epistêmico. Esse novo estado pode ou não ser definitivo: basta imaginar, por exemplo, a apresentação de um contra input e a conseqüente revisão, substituição ou ampliação desse segundo estado. Nesse sentido, notase que a evolução dos estados epistêmicos não é algo linear, mas algo que pode ser contradito e alterado. ${ }^{324}$

Apenas com intuito de deixar mais claro o que até aqui se disse, toma-se como exemplo - dentre os infinitos possíveis - a alegação hipotética de um acidente em que o motorista do ônibus estava embriagado. A embriaguez é colocada na inicial do autor como fato principal (FD). O réu, em sua defesa, nega o fato invocado pelo autor afirmando que, no momento do acidente, não estava bêbado (FFD). Nesse ponto, o juiz possui em relação à enunciação de fato um estado epistêmico de ignorância cognitiva (EsE0), vez que o conjunto de enunciados VFD/FFD é composto por asserções potencialmente falsas

\footnotetext{
${ }^{322}$ GÄRDENFORS, Knowledge in flux, cit. pp. 13 e ss.

${ }^{323}$ TARUFFO, Elementi, cit. 260.

${ }^{324}$ Giovanni SARTOR, Studi di lógica giuridica, Firenze, 1993, (edição provisória), pp. 17 e ss., na qual o autor trata com aprofundamentos dessa estrutura não monotônica.
} 
passíveis de comprovação (isto é, apofânticas), havendo tão somente um grau de percepção quanto ao conflito. Ao vir uma testemunha (input 1) e alegar que o motorista saiu de um bar antes de entrar no ônibus $\left(f_{s} l\right)$ e que apresentava sinais de que estava embriagado $\left(f_{s} 2\right)$, eventos dos quais se infere a veracidade de $\mathrm{FD}$, o estado epistêmico do juiz se modifica: passa-se agora a um estado epistêmico diferente de zero (EsE1). Entretanto, o réu poderá aportar aos autos um documento (contra input 1) no qual há um laudo extraído de um exame de sangue feito logo após o ocorrido $\left(f_{s} 3\right)$, que comprovaria que ele, naquela noite, não possui qualquer índice alcoólico em seu corpo, fato este que nega FD. Nesse momento, seu estado epistêmico EsE1 é substituído por EsE2.

Por essa perspectiva, nota-se que a formação do juízo sobre os fatos é algo dinâmico. Importante, pois, analisar em separado cada uma das modalidades de variação dos estados epistêmicos.

Segundo a doutrina que se dedicou ao tema, a expansão é a modalidade mais comum e mais importante dessas alterações ${ }^{325}$. Ela se dá quando o input confirma a veracidade ou falsidade de um enunciado fático. Em outras palavras, há expansion do estado epistêmico se houver prova de que aquele enunciado é falso ou verdadeiro. Da ignorância passa-se ao convencimento, quer ele positivo ou negativo, quanto a uma enunciação.

O juiz deverá interpretar e valorar os dados aportados pelos meios probatórios e verificar a atendibilidade daquelas informações de conhecimento. Não cabe nesse momento adentrar no tema da valoração dos meios de prova, tampouco nas questões relativas aos standards de conhecimento. O que interessa ao presente estudo é que a expansão transforma uma hipótese incerta em um enunciado confirmado ou negado. ${ }^{326}$

Uma segunda modalidade das modificações é a denominada redução. Essa alteração do estado epistêmico se dá de forma simétrica, porém oposta, à expansão. Após a aquisição de um grau de convencimento sobre um determinado fato, vem um input posterior que retira ou anula os dados informativos anteriores. Há uma perda do conteúdo adquirido retornando-se a um estado de dúvida em relação àquele enunciado, que volta a

\footnotetext{
325 TARUFFO, Elementi, p. 261.

${ }^{326}$ Idem, ibidem. O autor aponta para uma bifurcação da modalidade. Cita a routine expansion, que é a tradicional apontada no texto, e as deliberate expansion, nas quais as modificações advêm de inferências lógicas formuladas dentro do próprio estado epistêmico.
} 
ser incerto ${ }^{327}$. Para essa situação, basta pensar em dois exames aportados em momentos distintos com resultados opostos. ${ }^{328}$

Uma terceira e última modalidade é aquela denominada pela doutrina de revisão ou substituição (revision ou replacement) ${ }^{329}$. É a situação na qual há uma contração seguida de uma expansão. Um conteúdo cognoscitivo inicialmente existente é anulado, tomando seu lugar outro conteúdo. No caso proposto dos exames contraditórios, pode-se pensar em um terceiro resultado diferente do primeiro e confirmando o segundo. Assim, o juiz, que inicialmente havia um estado epistêmico oriundo do primeiro input $(+)$, passou a ter um estado reduzido pelo contra input (-), que depois se expandiu por um terceiro ulterior (-).

Do que fora dito até o presente momento, dois pontos devem ser ressaltados: o primeiro é que as alterações dos estados epistêmicos, como já explanado, não se dão de maneira linear e lógica. Elas ocorrem de acordo com os inputs variáveis do processo, podendo haver expansão, substituição, nova expansão, uma segunda substituição etc. $\mathrm{O}$ segundo ponto é que, a despeito de referente a cada enunciado individualizado, compõe um processo extremamente complexo e ziguezagueante. Qualquer simplificação do juízo de cada enunciado e, conseqüentemente, do conjunto de enunciados é mera ilusão.

Até o presente momento analisou-se os estados epistêmicos referentes a enunciados como se eles tivessem dentro do cenário global de enunciações um mesmo grau de importância. Ocorre, todavia, que dependendo do contexto em que inseridos, alguns enunciados são mais importante que os demais, apresentando suscetibilidade de alteração relacional menor. Explica-se.

Em um cenário processual, o estado epistêmico relativo a um fato principal (FD) não depende obrigatoriamente do estado epistêmico de um fato secundário $(f s)$. A recíproca, por outro lado, não é verdadeira. Assim, por exemplo, se um $f_{s} 1$ for comprovadamente falso, não significa que o FD1 a qual ele se relaciona seja também falso. Entretanto, se FD1 for falso há uma direta exclusão do estado epistêmico referente a $f s 1$.

${ }^{327}$ GÄRDENFORS, Knowledge in flux, cit. p. 60.

${ }^{328}$ Quanto à redução, TARUFFO indica duas subespécies: a uncoerced contraction, que consiste na eliminação de dados de conhecimento por incoerência interna ao estado epistêmico. Ou ainda, no âmbito processual, no caso de provas inadmissíveis. Ibidem, p. 264.

${ }^{329}$ GÄRDENFORS, Knowledge in flux, cit. p. 52. 
Tal diferença de estabilidade quanto aos estados de um e de outro é denominada de epistemic entrenchment. ${ }^{330}$

O mesmo fenômeno ocorre com os fatos secundários $(f s)$ e os secundários subsidiários $(f s s)^{331}$. Se um fato referente a um meio de prova tem seu estado epistêmico reduzido ou apresenta uma expansão de falsidade, o fato secundário se manterá, em regra, incólume. Nota-se, pois, que há uma gradação entre a estabilidade dos estados de acordo com a importância dos fatos ante o cenário em que inseridos.

Todas essas relações também entram em jogo quando se trata de juízo de fato e, conseqüentemente, da fixação da premissa menor do julgamento.

A teoria do knowledge in flux é aplicável a todas as áreas científicas. A diferença entre o direito e os demais ramos do conhecimento é que no cenário jurídico o desenvolvimento dos estados epistêmicos se dá regulado pelas fases processuais. Logo, há um momento no qual o juiz deverá emitir uma decisão, não podendo buscar os limites factuais eternamente. O procedimento, após um determinado ponto, bloqueia a entrada de novos enunciados e novos inputs.

Justamente por isso, pode-se falar em um estado final sobre os enunciados de fato. Nesse momento, o juiz haverá, ou ao menos assim se espera, um estado de true bilief em relação aos fatos relevantes para a decisão. Alguns enunciados serão verdadeiros (V), outros falsos (F), ainda havendo aqueles não provados (NP), dos quais os estados epistêmicos serão iguais aos iniciais.

Assim, se tomado o conjunto de enunciados fáticos existentes pós-contestação, réplica e eventuais contra-ataques, poder-se-á verificar algumas situações. São elas: todos os FD como verdadeiros; alguns FD verdadeiros e os demais comprovadamente falsos; todos os FD falsos; alguns FD verdadeiros e outros não provados; alguns FD falsos e outros não provados; todos os FD não provados

Para fins de aplicação das regras aos fatos, cada situação descrita implicará um desfecho distinto. Sobre a escolha da norma e a construção da premissa de direito se destinará o próximo item. Para o momento, porém, é fundamental destacar que a premissa

\footnotetext{
${ }^{330}$ GÄRDENFORS, Ibidem, pp. 75 e ss., especificamente pp. 86 e ss.

331 TARUFFO, Elementi, p. 267-268.
} 
de fato é o resultado do complexo processo de evolução dos estados epistêmicos, modificados a cada valoração e análise dos inputs existentes.

A simplificação com a qual a doutrina trata o tema, como mais uma vez se repete, não se sustenta.

\subsection{O juízo de direito - a individuação da norma}

O item anterior buscou demonstrar como e se sobre o quê se dá o juízo de fato. Tentou-se demonstrar esquematicamente como o juiz, inserido em um contexto processual, constrói as premissas de fato que estarão à base da decisão. Cabe nesse momento evoluir o estudo da formação do juízo e tentar explanar, ainda que de forma sucinta, como o julgador individualiza a norma aplicável ao caso concreto.

Em geral, os estudiosos do tema da aplicação do direito, principalmente no ramo da ciência processual, não costumam enfrentar as questões relativas ao modo de construção das premissas maiores do juízo. Em regra, os estudos dedicados à aplicação da lei abordam temas como a vinculação do juiz às asserções jurídicas das partes, os limites sobre os quais o juiz pode alterar livremente os dispositivos legais apontados na peça introdutória sem alterar os contornos da demanda, ou mesmo buscam respostas para perguntas como: até que ponto o magistrado está autorizado a cambiar as vestimentas legais dadas aos fatos que compõe a crise entre os sujeitos?

Como é fácil perceber, tais problemas tomam como premissa dois pontos: o primeiro é que cabe ao autor impor os limites da demanda, vez que o princípio dispositivo reina na sistemática processual brasileira - de resto, na maioria dos países ocidentais. Considerando que a demanda é identificada pelos três elementos (e a qualificação jurídica é tida como a chamada causa de pedir próxima), o juiz, pelo princípio da correlação, deverá ter sua atividade de fixação da premissa maior limitada. O segundo ponto é que a visão silogística da decisão e a simplificação extremada da atividade decisória, na qual as premissas estão prontas esperando apenas a confirmação ou não da subsunção, faz com que se relegue o problema da formação dos juízos fáticos e de direito a um segundo plano de importância. Conforme se expôs alhures, tais pontos não se sustentam, salvo, evidentemente, se aceitar o reducionismo tradicional. 
Como foi visto no tópico anterior, a premissa fática é construída por meio de um procedimento cognitivo dinâmico, porém não linear. A construção da premissa de direito se dá em paralelo àquele, havendo muitos pontos de intersecção entre eles. Na verdade, ambos se influenciam mutuamente em vários momentos. São, em suma, interdependentes. ${ }^{332}$

Quando o juiz toma contato com o conjunto enunciativo trazido com a inicial, bem como com a sugestão normativa dada pelo advogado do autor, a estrutura jurídica atribuída aos acontecimentos e os pedidos, logo ele faz um recorte mental do ordenamento jurídico baseando-se no conhecimento prévio que possui, havendo-se desde já uma idéia de um conjunto mais ou menos amplo de regras que poderão ser aplicáveis àquela situação fática. Assim, por exemplo, se o autor traz elementos referentes aos direitos das obrigações, saberá o juiz onde encontrar o regramento positivo que regula a matéria.

O recorte, todavia, possui nesse momento caráter provisório e meramente indicativo, vez que o grau de conhecimento e o estado epistêmico do juiz ainda são nulos.

Ao contestar, o réu poderá negar a aplicabilidade das normas até então indicadas, negar os efeitos jurídicos dado pelo autor aos fatos, bem como desconstruir a roupagem de direito atribuída aos acontecimentos pelo patrono adverso. O juiz, então, poderá ampliar ou diminuir a área de abrangência do ordenamento por ele antes delimitada. Notam-se, ainda nesse estágio, as características acima apontadas de provisoriedade e indicatividade.

Quando o conjunto de enunciados fáticos entra em contato com os inputs probatórios, causando modificações nos estados epistêmicos do juiz, o cenário de individuação normativa pode ou não sofrer alterações. Ao atribuir certeza a alguns enunciados, os limites da área pré-determinada começam a afunilar.

Entretanto, como se viu acima, os estados epistêmicos podem tanto sofrer reduções quanto serem substituídos por outros. Em casos como estes em que o estado de conhecimento não aumenta, os influxos dos inputs e das conseqüentes alterações no juízo de fato refletem diretamente na escolha ampla do juízo jurídico.

Por outro lado, pode-se constatar que também a norma ajuda a selecionar e dar relevância a determinados enunciados sobre os fatos. São elas que estabelecem os critérios

${ }^{332}$ TARUFFO, Legalità e giustificazione della crezione giudiziaria del diritto, in (estratto) Riv. Trim. Dir. Proc. Civ., 2001, p. 13. 
que dão destaques e importância a pedaços dos eventos narrados. Tal qual escrito, é o suporte fático das normas que dirá quais são os fatos principais, quais serão tidos como secundários e ainda quais serão os irrelevantes.

A doutrina caracteriza esse procedimento como sendo um círculo. É o chamado círculo hermenêutico da aplicação do direito ${ }^{333}$. Há parte dos estudiosos que dizem que não se tratar de uma circunferência, mas de sim de um espiral, já que o procedimento avança independentemente das contramarchas existentes. Independentemente da forma geométrica que se adote, fato é que ambas as construções se influenciam reciprocamente, uma influindo diretamente nos limites da outra. ${ }^{334}$

Aliás, tal influxo dos fatos em relação à construção da premissa maior não se dá tão somente no âmbito da extensão, mas também de seu conteúdo. Assim, é diante do cenário fático e sua evolução confirmativa que os conteúdos das expressões das normas irão se formando. $^{335}$

É fácil pensar em uma hipótese em que o juiz altere as bases das premissas de direito conforme as mudanças de estado epistêmico relativo aos enunciados de fato. Pensese, por exemplo, em uma ação de cobrança proposta por hospital particular em face de paciente operada fundada em 'contrato particular de prestação de serviços médicos e hospitalares ${ }^{336}$. Em resposta, o réu afirma que assinou o citado instrumento tão só porque o hospital, por tratar-se de instituição privada, se negou a realizar as intervenções cirúrgicas cardíacas em sua mãe. Em reconvenção, alega que, como quem escolheu o hospital foi o órgão público responsável que resgatou sua genitora, o comportamento adotado pelo hospital configura o instituto da coação e, por isso, requer a anulação do negócio jurídico. Não houve, como se nota, nenhuma referência à gravidade do estado de

333 KAUFMANN, Sulla circolarità nell'individuazione del diritto, in Filosofia del diritto ed ermeneutica, Milano, 2003, pp. 115 e ss.

${ }^{334}$ Nas palavras de TARUFFO, "Come ha messo in luce con particolare chiarezza l'analisi ermeneutica della decisione giudiziaria, la scelta della norma applicabile e la determinazione del su significato avvengono in diretta connessione dialética con l'individiazione dei fatti giuridicamente rilevanti; d'altra parte, questa determinazione dei fatti avviene in funzione della norma che il giudice ritiene applicabilie e del significato ('guidato' dal riferimento ai fatti) che alla norma viene assegnato", Legalità e giustificazione, cit. p. 13. Nesse mesmo sentido, JOSEF ESSER, Precomprensione e scelta del método nel processo di individuazione del diritto, traduzione Salvatore Patti e Giuseppe Zaccaria, Napoli, 1983, p. 24 e ss.

${ }^{335}$ KAUFFMANN, Sulla circolarità, cit. p. 126. A relação entre a interpretação e o contexto foi desenvolvida acima.

${ }^{336} \mathrm{O}$ exemplo é retirado, com algumas adaptações ao objeto do estudo, do seguinte acórdão: TJSP, Apl. $\mathrm{n}^{\circ}$

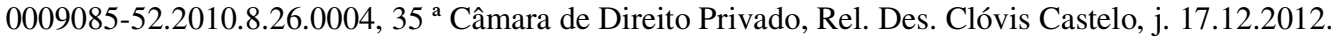


saúde da paciente, da urgência da intervenção, etc. As alegações se limitam ao conjunto apontado.

Com o evoluir procedimental, vem aos autos um prontuário da paciente indicando que o caso era de extrema urgência e que a genitora do réu fora levada diretamente ao centro cirúrgico. Em relação às exigências coercitivas hospitalares narradas, de início não negadas pela instituição reconvinda, são confirmadas por uma testemunha. Dois inputs, pois, vêm a alterar o estado cognitivo do juiz: o primeiro relativo a enunciados que sequer compunham o conjunto inicial, mas que adquiriram status de fato secundários com os documentos juntados. O segundo é relativo à afirmação da testemunha; há aqui uma expansão do estado inicial zero. Nesse momento, o instituto da coação e seu regramento pelo Código Civil ganha relevo para o juiz.

Entretanto, em momento ulterior, apresenta-se um vídeo em que consta toda a gravação da entrada da paciente e da assinatura do instrumento de negócio jurídico pelo seu filho. Nele, não se nota qualquer exigência por parte do hospital, somente a aflição dos envolvidos. Nesse momento, há uma redução do estado epistêmico do juiz quanto à alegação do réu-reconvinte. O cenário jurídico pensado e fundado nos arts. 151 e ss. do CC também se retrai. Contudo, os enunciados fáticos relativos à situação da paciente ganham relevo. O juiz, nesse momento, troca o foco de sua lente jurídica para a seção subseqüente do diploma civil. Os fatos, agora, passam a indicar uma roupagem jurídica de estado de perigo, que também autoriza a procedência da reconvenção.

Aliás, os próprios fatos é que condicionarão a interpretação se houve ou não necessidade de salvamento da própria pessoa ou alguém de sua família, se havia ou não grave dano aos envolvidos e se a obrigação assumida era ou não excessiva, parte estas dos enunciados que devem ser valoradas.

Com o cenário fático definido e um estado epistêmico definitivo quanto a ele, uma idéia permanente quanto ao direito estará formada.

A teoria hermenêutica dos círculos probatórios, combinada com a do knowlegde in flux, reproduz a contento o processo de construção pelo juiz das premissas maiores e menores. Demonstram que tal construção não é algo simplista, mas complexo, dinâmico e variável. 
O esquema demonstrado pode causar perplexidade, muitas vezes, pelas aberturas que oferece a uma eventual discricionariedade por parte do intérprete: o juiz. Contudo, quanto ao ponto, dois pontos devem ser ressaltados. O primeiro é que uma interpretação mecânica que tenha resultados iguais e homogêneos, ainda que tenham como objeto casos parecidos, é uma idéia bastante etérea e descolada da realidade ${ }^{337}$, embora fosse algo bastante interessante pela perspectiva da segurança jurídica. ${ }^{338}$

Ademais, a dinamicidade da função interpretativa do juiz, quer no que concerne ao cenário fático quer na compreensão dos termos da lei, não implica obrigatoriamente em algo arbitrário. Há nesse caminho por ele perseguido critérios de racionalidade que não podem ser esquecidos. São eles: coerência interna e universalidade. ${ }^{339}$

A coerência da decisão é justamente o que, geralmente, vem denominado de subsunção. Com os fatos corretamente acertados, deve haver uma correspondência entre a premissa de fato e o suporte fático normativo. A universalidade, por seu turno, é a possibilidade de 'expandir' a decisão do caso concreto às decisões segundo as regras abstratas. $^{340}$

Logo, embora composto por elementos subjetivos, o processo de individualização da norma ao caso concreto pode ser submetido a critérios de controle.

Para finalizar o tópico, resta ainda responder: quais os limites do princípio da iura novit curia?

O juiz, ao formular suas premissas de direito conforme o avançar de seu grau epistêmico de conhecimento, deverá sempre ter em mente o pedido do autor e a estrutura jurídica criada por seu advogado em busca do bem da vida. Em outros termos, o juiz

\footnotetext{
337 JOHN MERRYMAN, em estudo sobre a interpretação no direito italiano, chama a idéia homogênea e padronizada da construção da premissa jurídica ou a escolha da norma de folclore. Críticas e aprofundamentos, Lo 'stile italiano',,: l'interpretazione, in Riv. trim. dir. proc. civ., 1968, pp. 373 e ss. No mesmo sentido, GIUSEPPE ZACCARIA, 'Precomprensione' e controlli di razionalità nella prassi del giudice, in Riv. dir. civ. 1984, parte II, p. 315

${ }^{338}$ Embora seja importante a uniformização da jurisprudência, seu engessamento por uma decisão mecânica é algo problemático. Sobre o fato, ZACCARIA assim se manifesta: “(...) molte intrepretazioni giurisprudenziali si ispirano a criteri di valutazione extralegislativi, per la cui determinazione il giudice deve, di volta in volta, operare un rinvio alle valutazioni presenti nel contesto sociale. Attraverso le 'finestre di comunicazione' con la dinamica sociale, rappresentate dalle clausole generali e dai principi giurisprudenziali, si vanno integrando nel sistema del diritto privato i nuovi valori e orientamenti che la società pluralistica incessantemente produce”, 'Precomprensione' e controlli di razionalità nella prassi del giudice, cit. p. 314.

${ }^{339}$ TARUFFO, Legalità e giustificazione, cit. p. 21.

340 TARUFFO, idem, p. 22.
} 
deverá respeitar os limites daquilo que foi requisitado, não podendo ultrapassar o limite da dispositividade dos direitos pertencentes à esfera privada dos cidadãos. Os limites, pois, são os princípios dispositivos e da correlação, que serão tratados no tópico a seguir. ${ }^{341}$

\section{5 - O princípio dispositivo, o princípio da correlação e suas dimensões}

A maioria dos sistemas processuais ocidentais tem em suas bases dois princípios norteadores. São eles: o princípio dispositivo e o princípio da demanda/ação, ambos relacionados entre si.

O chamado princípio da demanda, expressamente previsto no art. $2^{\circ}$ do CPC brasileiro, institui como sendo atividade privativa dos cidadãos, ressalvadas algumas poucas exceções legais, dar início ao processo. É o interessado quem deve, por sua livre iniciativa, propor a demanda em busca de seus direitos. Calcado na inércia jurisdicional, estabelece-se um sistema processual também chamado de adversarial ${ }^{342}$, que se contrapõe ao denominado processo inquisitório, no qual o juiz pode iniciar o procedimento de ofício.

A expressão adversarial muitas vezes é substituída pelo termo dispositivo ${ }^{343}$. Doutrina e jurisprudência, então, costumam contrapor a estrutura processual inquisitorial a uma dita dispositiva. Esse intercâmbio de expressões sem qualquer ressalva gera confusões, fazendo com que muitos tratem o princípio da demanda como sendo equivalente ao princípio dispositivo. Entretanto, a permuta de termos não vem dada aleatoriamente, mas possui suas raízes na estreita ligação existente entre os dois.

Se princípio da demanda aqui equivale à inércia da jurisdição e se consubstancia no óbice legal posto ao juiz para iniciar um processo de ofício, o princípio dispositivo, por seu

\footnotetext{
${ }^{341}$ Para considerações sobre o princípio e as funções da jurisdição, ORMAZABAL SÁNCHEZ, Iuria novit curia, Barcelona-Madrid, 2007, pp. 82 e ss.

$342 \mathrm{Ou}$, mais usado no âmbito penal, processo acusatório.

${ }^{343} \mathrm{Ou}$, usando um conceito de princípio dispositivo processual, diverso daquele que se entende como correto, afirma-se que "no modelo adversarial, prepondera o princípio dispositivo, e, no modelo inquisitorial, o princípio inquisitivo”, FREDIE DIDIER JR., Os três modelos de direito processual: inquisitivo, dispositivo e cooperativo, in Repro, 2005, n. 127, p. 75.
} 
turno, tem seus contornos mais nebulosos ${ }^{344}$. Para enfrentá-lo, todavia, buscar-se-ão alguns conceitos já expostos anteriormente.

Em termos bastante resumidos - traçados tão somente para estruturar as premissas do raciocínio que se desenvolverá -, invoca-se a já mencionada relação existente entre os indivíduos e os bens da vida. Sabe-se que aqueles necessitam destes para suas sobrevivências e para suprir suas necessidades, sendo essas necessidades os elementos fundamentais definidores do conteúdo técnico de interesse. Ter interesse é, em linhas gerais, ter necessidade de um bem da vida. ${ }^{345}$

O Direito, por meio de sua atividade organizativa, buscou tutelar todos esses interesses e relações, tão diferentes entre si, de forma também variante. Aquelas necessidades fundamentais, que podem ser as básicas para a sobrevivência do indivíduo (educação, saúde etc.), ou aquelas que o próprio Estado titula como fundamentais para a estruturação do bem estar social, possuem um olhar mais atento pelo ente estatal. Em relação a eles, vedou-se a qualquer um, independentemente de quem seja, a prática de atos de disposição por meio da vontade. São estes interesses os chamados indisponíveis. Em contraposição a eles, o direito material e o sistema jurídico posto prevêem uma gama de direitos relativos a interesses que podem ser alvo de disposição por meio da iniciativa voluntarista dos sujeitos de direito capazes.

Nesse sentido, conforme tem se posicionado parte da doutrina, o princípio dispositivo versa tão somente sobre o direito material, e não sobre o processo ${ }^{346}$. Os sujeitos de direito podem dispor de uma relação jurídica pertencente a eles e existente no

\footnotetext{
${ }^{344}$ Apontando para a dificuldade de definição do princípio dispositivo em termos gerais, questionando o uso como sinônimo do princípio da demanda, BARBOSA MOREIRA, diz: "Conheço poucos expressões tão equívocas em ciência jurídica como esta: princípio dispositivo. Ela é usada em diversíssimos contextos, ora para aludir à iniciativa da instauração do processo (diz-se que a parte é que deve tomar a iniciativa em razão do princípio dispositivo, porque, se ela não quer postular o seu direito, o problema é seu, e a atitude deve ser respeitada), ora para aludir à delimitação do objeto do processo e, portanto, do objeto do julgamento", Correlação entre pedido e a sentença, in, Repro, 1996, n. 83, p. 208.

${ }^{345}$ Ver notas da introdução ao capitulo II. Ademais, nesse sentido, José CARLos BAPTISTA PuOLI, Poderes do Juiz e as Reformas do Processo Civil, São Paulo, 2002, p. 23.

${ }^{346}$ No sentido do texto, JOSÉ ROBERTO DOS SANTOS BEDAQUE afirma que é "preferível que a denominação 'princípio dispositivo' seja reservada tão-somente aos reflexos que a relação de direito material disponível possa produzir no processo. E tais reflexos referem-se apenas à própria relação jurídico-substancial", concluindo que "Essa sim corresponde à verdadeira e adequada manifestação do princípio dispositivo. Tratase de um princípio relativo à relação material, não processual”, Poderes Instrutórios do Juiz, São Paulo, 2009, p. 91.
} 
plano substancial. Falar de disposição de direitos, pois, remete o interlocutor aos regramentos e institutos, em geral, do direito privado.

É bem verdade que essa característica de alguns direitos causa reflexos no plano processual $^{347}$, principalmente no que se refere ao seu objeto. O indivíduo, devendo, em regra, utilizar-se do processo para resolver suas insatisfações, deve delimitar até que ponto o juiz poderá intervir na esfera privada dos seus direitos. Dessa maneira, cabe à parte definir a exata demarcação autorizativa de atuação do Estado. ${ }^{348}$

Apenas com o fim de aclarar o que aqui se tenta explicar, invoca-se um caso hipotético, dentre tantos outros possíveis, de restituição de valores fundada em nulidade do contrato. $\mathrm{O}$ autor, ao apenas fundamentar sua demanda no vício - e deixando de lado o debate sobre se a nulidade é ou não matéria cognoscível de ofício -, não deseja que o Estado anule o dito negócio jurídico, pertencente à sua esfera de direitos subjetivos disponíveis. Quer, isso sim, que o juiz manifeste-se tão só quanto ao objeto de uma das obrigações ali previstas.

Logo, se pudesse o juiz iniciar o processo por iniciativa própria, via de regra, invadiria com sua decisão final o leque de direitos dos cidadãos, sendo tal conduta, muitas vezes, contra a própria vontade dos indivíduos envolvidos, ferindo, com isso, a dispositividade prevista pelo próprio Estado àquela determinada relação ${ }^{349}$. Diante disso, pode-se facilmente notar o liame existente entre princípio da demanda e princípio dispositivo. O primeiro é um dos meios pelos quais se assegura o segundo. Tal ligação é, como se disse, responsável pelo intercâmbio e pelo uso indiscriminado entre os conceitos.

\footnotetext{
347 BEDAQUE, op.ult.loc.cit, por exemplo, cita disposições do direito substancial por meio de atos processuais. Nesse sentido: “Assim, tratando-se de direito disponível, as partes têm ampla liberdade para dele dispor, através de atos processuais (renúncia, desistência, reconhecimento do pedido). E não pode o juiz opor-se à prática de tais atos, exatamente em virtude da natureza do direito material em questão".

348 JOAN PICÓ JUNOY, Iudex iudicare debet secundum allegata et probata, non secundum conscientiam: storia della erronea citazione di un brocardo nella dottrina tedesca e italiana, in Riv. dir. proc., 2007, p. 1516.

${ }^{349}$ BARBOSA MOREIRA, com a sensibilidade que lhe é peculiar, aponta que há no sistema previsões legais que autorizam o juiz a iniciar um processo mesmo se tratando de direito disponível. É o caso do art. 979 do CPC, que trata do inventário. Segundo o autor, essa seria a prova de que princípio dispositivo e princípio da ação não são confundíveis entre si, conforme comumente se vê. Cita, outrossim, que casos envolvendo direitos indisponíveis não têm alvará para terem início oficial só porque indisponíveis. Nesse sentido, Correlação entre o pedido e a sentença, cit. p. 208.
} 
No que tange ao objeto do trabalho, importante notar que o princípio dispositivo, entendido de maneira equivocada por parte da doutrina, muitas vezes é usado com uma abrangência maior do que realmente possui.

Como fora dito em alguns poucos parágrafos acima, cabe aos sujeitos de direito que vêm a juízo delimitar qual é a área de ingerência estatal possível na suas esferas de direitos. A doutrina e a jurisprudência, conforme já exposto, ao identificar o objeto do processo por meio dos ditos três elementos da demanda, quais sejam: partes, causa de pedir e pedidos, acabam incluindo as alegações de fato e de direito nas áreas restritivas da atuação estatal.

Desse modo, partindo-se da premissa correta de que é ônus da parte definir os limites de intervenção do Estado, sendo vedado, pois, ao juiz interferir no âmbito privado sem que tenha sido provocado, tudo exatamente pela característica de dispositividade dos direitos, e sendo, segundo a doutrina clássica, os fatos, a qualificação jurídica e os pedidos responsáveis por identificarem o tal objeto da demanda, então, por uma ilação equivocada, estaria também o Estado proibido de interferir na formulação dos enunciados fáticos e jurídicos trazidos pelo autor e réu em suas manifestações iniciais por conta do mesmo princípio.

Observando-se o dispositivo legal do Código de Processo que regula os requisitos do ato introdutório, o qual exige que o autor exponha os fatos e seus fundamentos jurídicos, poder-se-ia ter a impressão, por meio de mais uma ilação sem fundamento, de que o sistema positivo contemplou a lógica ali exposta. Nada mais equivocado.

Primeiro pela simples razão de que ninguém dispõe de fatos e acontecimentos da $\operatorname{vida}^{350}$. Segundo, pelo motivo de que as ilações feitas somente fazem sentido se a premissa adotada for de que uma demanda deve ser obrigatoriamente identificada pelos elementos apontados, tomando-se a causa de pedir e o pedido como conceitos absolutos e já delimitados analiticamente no ato introdutório e de defesa, o que, como se viu, não é a estrutura mais condizente com a realidade.

Para se demonstrar que os limites do princípio dispositivo não alcança os fatos - e, portanto, a lógica apresentada acima não se sustenta-, basta imaginar situação na qual o

\footnotetext{
${ }^{350}$ Por outra perspectiva, demonstrando que alegações de fato sem qualquer vinculação jurídica - uma simples narração de acontecimento, nada têm de relação com o princípio dispositivo, CARRATTA, Il principio della non contestazione nel processo civile, Milano, 1995, pp. 247 e ss.
} 
juiz formula enunciados fáticos de ofício referentes, por exemplo, a um acidente. Nenhuma das partes havia alegado que ônibus causador do desastre não passava por revisões já há algum tempo, evento esse, portanto, pertencente ao universo de seu conhecimento privado. Caso o magistrado profira uma decisão fundada nesse enunciado atribuindo ao autor os exatos termos do que ele havia pedido a título de ressarcimento pelos danos, estará o juiz cometendo uma série de infrações e equívocos, mas nenhum deles referentes à dispositividade do direito obrigacional em disputa. O Estado não interferiu nem mais nem menos na esfera privada dos sujeitos. Ao contrário disso, o fez nos exatos termos substantivos do que lhe fora requisitado.

Para sair da patologia, basta pensar nas matérias autorizadamente cognoscíveis de ofício. Caso o juiz fundamente sua decisão em fatos dessa natureza, não há como sustentar que houve infração ao princípio dispositivo pelo simples aporte de eventos não alegado pelas partes. O mesmo se dá, como já fora dito, quando a decisão se funda em fatos trazidos por sujeitos terceiros participantes do processo, tais como testemunhas, peritos, oficiais de justiça etc. ${ }^{351}$

A questão que surge, pois, é: por qual razão, então, o juiz não pode formular enunciados sobre fatos não constantes nos autos? A razão é simples e já foi mencionada nesse estudo: mera vedação legal por parte do art. 128 do $\mathrm{CPC}^{352}$. O Código processual veda o uso do conhecimento privado do juiz ${ }^{353}$. Uma autorização desse gênero, certamente, colocaria grandes empecilhos a uma maior efetividade dos princípios do contraditório e da ampla defesa.

351 Como já referido em nota nesse capítulo, o art. 131 do CPC brasileiro autoriza o juiz a apreciar "livremente a prova, atendendo aos fatos e circunstâncias constantes dos autos, ainda que não alegados pelas partes; mas deverá indicar, na sentença, os motivos que lhe formaram o convencimento".

${ }^{352}$ Para uma introdução sobre ciência privada, FRIEDRICH STEIN, El conocimiento privado del juez, tradução ANDRÉS DE LA Oliva SANTOS, Madrid, 1990, pp. 71 e ss.. Para diferenciações entre o princípio dispositivo e a impossibilidade do uso do conhecimento privado por parte do juiz, além de análise da legislação italiana e no sentido do texto aqui escrito, TARUFFO, Commentario breve al codice di procedura civile, Padova, 2012.

${ }^{353}$ Para uma distinção entre conhecimento privado, senso comum e máximas da experiência, sem intenção de exaurimento, TARUFFO, Senso comune, esperienza e scienza nel ragionamento del giudice, in (estratto) Riv. trim. dir. proc. civ., 2001, pp. 665 e ss. 
É com parâmetros nessas observações, acredita o autor do presente trabalho, que o brocardo romano do judex secundum allegata et probata partium judicare debet deve ser interpretado, sendo a expressão "secundum allegata" relativa à vedação legal exposta. ${ }^{354}$

Feitas essas rápidas observações quanto ao princípio dispositivo, acredita-se que a base teórica e as premissas necessárias já estejam postas para o enfrentamento do princípio da correlação entre pedido e sentença.

Parte significativa tanto da doutrina quanto da jurisprudência, pautada pela extensão equivocada do conceito de dispositividade, bem como partindo de premissas silogísticas da aplicação do direito - conforme foi visto nos itens precedentes-, interpreta o dever de a sentença possuir a mesma extensão que o objeto do processo como sendo uma vinculação do juiz ao cenário descrito na inicial. A metodologia de identificação da demanda pela causa de pedir e pedido, mais uma vez, induz a ilações e extensões principiológicas equivocadas.

Diferentemente do se afirma, a correlação não obriga o juiz a julgar com base nas exatas enunciações fáticas formuladas pelos advogados das partes. Tampouco o magistrado está vinculado à estrutura e à roupagem jurídica construídas por eles. O juiz deve, de acordo com o princípio dispositivo, interferir na esfera privada dos direitos dos cidadãos apenas nos limites para os quais foi provocado. Logo, o impacto de sua de sua decisão deve atingir tão somente aquele pedaço do "leque" de direitos que foi posto em debate. Julgar o pedido e só o pedido é o conteúdo correto do princípio da correlação. ${ }^{355}$

Feitos esses esclarecimentos, pode-se agora entrar no tema verdadeiro e próprio do trabalho: a modificação da demanda, que será desenvolvido no capítulo subseqüente.

\footnotetext{
${ }^{354}$ Mostrando as variações do brocardo e concluindo que seu correto conteúdo é o de limitar o juiz a resolver o caso em função do que fora alegado e provado no processo, sem utilizar sua ciência privada, PICÓ JUNOY, Iudex iudicare debet secundum allegata et probata, cit., p. 1518.

${ }^{355}$ BARbosa MoReIRA, Correlação, cit. p. 211. Vale lembrar que o pedido, conforme dito no item 2.6, não deve ser entendido como a expressão formal externalizada na inicial, pois essa pode ser defeituosa por uma série de razões subjetivas ali apontadas. O pedido a que se refere, portanto, é o de tutela apta a resolver a crise posta.
} 


\section{A MODIFICAÇÃO DA DEMANDA - PROPOSTA DE NOVOS CONTORNOS PARA UM INSTITUTO}

Os capítulos precedentes buscaram demonstrar como se dá a formação do ato introdutório do autor - lógica construtiva, de resto, que permeia a contestação do réu e todas as demais manifestações de ambas as partes ao longo do processo - e os juízos de fato e de direito que culminam na decisão pelo órgão julgador.

Como se pôde perceber, as enunciações feitas na inicial e na contestação, por inúmeros motivos elencados, não são nem de longe uma representação exauriente do conflito existente no plano fenomênico. Dentre as diversas razões estão: a) a incapacidade da atividade narratológica de enunciação, por sua própria natureza, em trazer toda a complexidade dos eventos concretos, ainda que se tratem se fatos simples; b) as posições epistemológicas dos sujeitos envolvidos que, em busca de seus próprios interesses, recortam a realidade conforme seus objetivos ante o processo e o bem em disputa, trazendo aos autos tão somente a parte que lhes convêm dos acontecimentos, via de regra, selecionados de acordo com uma tese jurídica subjetivamente construída; e c) pela possível falsidade dos seus conteúdos.

Nesse sentido, ressaltando algo que já fora dito, a formação do ato introdutório referente ao mesmo caso é naturalmente variável. Os enunciados fáticos e as teses jurídicas serão estruturados de maneiras diversas se feitos por patronos diferentes. Aliás, como exercício de raciocínio, é tranquilamente possível afirmar que o mesmo advogado, se submetido a uma atividade construtiva mais de uma vez, trará representações do conflito distintas entre si. A inicial e a contestação, portanto, nunca serão as mesmas, ainda que a contenda objeto de descrição for mantida.

Justamente por isso, acredita-se que o conceito de causa de pedir, longe da simplificação comumente feita pela doutrina tradicional, é apenas um elemento informativo descritivo trazido pelo autor em relação ao conflito. Distante de ser analiticamente definido e com contornos rígidos, é um instituto que se desenvolve e se aperfeiçoa com o caminhar do processo. Logo, é um elemento incapaz de identificar a demanda com seus limites iniciais propostos e interessadamente construídos pelos patronos dos envolvidos. 
As mesmas observações cabem quanto aos elementos de direito. Fundamentalmente dependentes da interpretação feita pelos advogados em relação ao conflito, não é correto tomá-lo como elemento rígido, definitivo e perene durante todo o processo ${ }^{356}$. Tampouco é capaz de identificar a crise originada no âmago da sociedade por meio de sua configuração original proposta.

A análise epistemológica de ambos os requisitos da inicial mostra que as tentativas da doutrina tradicional em definir causa de pedir e pedido são insatisfatórias e geralmente infrutíferas, tudo devido ao fato de abarcarem sobre um mesmo conceito abstrato e simplista situações tão diversas e variáveis da realidade. Em outros termos, tentar colocar todas as possibilidades existentes na prática de narrar os fatos e estruturá-los juridicamente sob um mesmo conceito uniforme de causa petendi, por exemplo, é o mesmo que forçar a realidade a adaptar-se às simplificações de um modelo teórico, o que certamente não será possível salvo um descolamento e abandono do plano concreto. ${ }^{357}$

Não bastasse isso, usar os dois elementos descritos acima como identificadores de uma demanda, jogando sobre a técnica identificativa um sistema preclusivo rígido, o que faz desaguar, como se vê, em um enclausuramento dos conjuntos enunciativos e jurídicos nas manifestações iniciais das partes, causa uma deformação na representação da crise sobre a qual o juiz deverá se manifestar. ${ }^{358}$

O modelo tradicional, então, mantém estável a formatação parcial, interessada e incompleta do conflito traçada pelos sujeitos envolvidos, gerando impactos diretos no processo formativo das premissas maiores e menores por parte do julgador, momento no qual somente terá sido afastada a característica de potencial falsidade do conjunto enunciativo ou de alguns enunciados.

Dessa maneira, levando em consideração os conceitos e requisitos de uma decisão justa, bem como a dinamicidade processual, uma nova estrutura para os limites

\footnotetext{
${ }^{356} \mathrm{Na}$ já citada obra de MONTESANO, assim consta: "Se la domanda si inquadra, dunque, nel procedimento, appare súbito chiaro che essa è sì 'proposta' con l'atto introduttivo del giudizio (v. ad es. l'art. 99 c.p.c.), ma durante il giudizio si svolge (o - per usare le parole del nostro c.p.c. sai nel testo originario sai in quelli della 'novella' del 1950 e dell'ultima riforma del 1990, destinata, salvi imprevisti, ad entrare in vigore dal gennaio 1993 - so 'precisa' e 'modifica') con una serie ulteriore di atti, che sono di parte, ma non di rado sono originati da impulsi giudiziari, più o meno intensi a seconda dalle varie normative procedimentali e delle vincende concrete di ogni lite", Diritto sostanziale e processo civile, cit. p. 66.

${ }^{357}$ Nesse mesmo sentido, GAMBA, Domande, cit. p. 223.

${ }^{358}$ Com observações muito semelhantes, GAMBA, ibidem, p. 225.
} 
modificativos deverá ser pensada, tomando-se como premissa o afastamento da técnica identificativa e de seus reflexos nos atos iniciais. É o que se buscará fazer.

\subsection{Modificação da demanda - proposta de um novo conceito}

Conforme foi dito inúmeras vezes ao longo do trabalho, a petição inicial do autor, tal qual a contestação do réu, não tem à sua base fatos, entendidos como acontecimentos naturalísticos, mas enunciados sobre os fatos. Longe de ser apenas uma questão terminológica, a primeira expressão representa uma simplificação da realidade, ao passo que a segunda carrega em si todas as premissas epistemológicas apontadas no capítulo 2, retro.

Desse modo, o primeiro ato do processo tem como elemento formador frutos de uma atividade lingüística, que traz em si informações direcionadas pelos seus criadores relativas aos acontecimentos sobre os quais repousa a insatisfação trazida a juízo ${ }^{359}$. A tese jurídica, no mesmo sentido, representa uma roupagem dada pelo advogado de maneira subjetiva, nada mais sendo que sua interpretação parcial dos relatos e documentos trazidos por seu cliente. Nesse sentido, diferentemente do que propõe a doutrina clássica, a causa de pedir e o pedido são meros veiculadores de informação com os quais o defensor do autor insere no âmbito do processo elementos hipotéticos do conflito real até então desconhecidos pelo juiz. ${ }^{360}$

O conteúdo informativo desses atos, como referido, não é completo no momento da propositura da demanda. Ao contrário, se desenvolve da maneira explicada pelas teorias acima expostas do knowledge in flux e da circularidade hermenêutica da aplicação do direito.

Destarte, o primeiro passo para uma construção de um novo modelo de modificação da demanda é atribuir um conteúdo meramente informativo aos ditos elementos objetivos da inicial, abandonando-se por completo a idéia simplificativa normalmente propalada de caráter rígido e definido dado pela teoria identificativa clássica. Essa mudança de

\footnotetext{
${ }^{359}$ SEARLE, actos de habla, cit., pp. 58 e ss.

${ }^{360}$ Sobre o conceito de leitor não informado e seu impacto prático, ver retro 2.3. Das narrativas em geral.
} 
perspectiva e conteúdo, por si só, já confere ao sistema um perfil mais flexível à modificação, conforme se verá melhor adiante.

Ademais, a expressão 'modificação da demanda' não deverá ser encarada em sua acepção literal, isto é, não serão seus termos tomados ao pé da letra. Isso porque a idéia de 'modificação', em geral, requer que se faça, primeiramente, uma identificação do objeto de análise. Não se pode, logicamente, afirmar que algo foi modificado sem que se saiba, antes disso, quais eram os reais contornos originários daquele determinado objeto.

Dizer que algo sofreu modificações envolve, nesse sentido, um juízo comparatístico do observador, pressupondo, em outros termos, que havia por parte dele uma correta compreensão da definição da coisa sob análise e, posteriormente, a identificação de um acréscimo, substituição ou de um decréscimo de dados àquela significação fundamental originária.

Assim, em específico, o estudo da modificação da demanda - quer pela perspectiva de seus aspectos objetivos, quer no que tange ao aspecto subjetivo - não fugiria, se assim interpretada, à regra lógica apontada acima, cabendo àquele que se debruçasse sobre esse instituto jurídico apontar, em momento anterior ao enfrentamento do tema da alteração, as formas de identificação das demandas, método justamente abandonado pelo trabalho.

Logo, 'modificação da demanda' será tida como sinônimo de alteração ou inserção, durante o curso do procedimento, de enunciados fáticos e jurídicos - individualmente considerados ou levando-se em conta o conjunto enunciativo como um todo - e/ou a alteração, subtração ou inserção de pedidos formulados nas manifestações das partes após a fase postulatória. ${ }^{361}$

A manutenção da expressão em seus termos tradicionais se dá por duas razões principais. A primeira é pelo fato de que se trata, em termos práticos, da mesma problemática enfrentada pela doutrina clássica identificativa, alterando tão somente a perspectiva de análise. A segunda é que configura uma expressão já consagrada no meio jurídico, o que dificultaria uma construção lingüística que desencadeasse uma ligação direta entre a nova terminologia e seu objeto.

${ }^{361}$ Uma leitura atenta pode notar que não foi colocada a subtração de enunciados de fatos e jurídicos como sendo parte do instituto modificativo. O tópico seguinte trará a razão de ser dessa exclusão. 
Encarado desse modo o tema do trabalho, percebe-se que o instituto modificativo não está vinculado a qualquer teoria em específico, mas terá seus limites ditados tão somente pela estrutura preclusiva adotada pela lei processual. Tal alteração do foco não resolve o problema. Ao contrário disso, traz problemas ulteriores que podem ser representados pelas seguintes - mas não só - perguntas: qual o momento ideal para que haja o bloqueio das atividades modificativas das partes? Sobre qual conteúdo deverá incidir o instituto preclusivo? Sobre quem se abate? Quais seus limites impeditivos? Dentre tantas outras.

Antes de se aprofundar sobre a problemática apontada acima, cabem, para o momento, algumas considerações iniciais sobre o conceito de preclusão, que, segundo a doutrina, não é nada pacífico ${ }^{362}$, porém deve ser encarado, pois servirá de premissas para o desenvolvimento de todo o raciocínio que se traçará adiante.

E, para entender corretamente a preclusão, fundamental analisar o processo sob a perspectiva das inúmeras posições jurídicas concatenadas que são assumidas pelas partes e pelo juiz ao longo de todo o procedimento, isto é, do ato introdutório ao ato afinal. ${ }^{363}$

Foi dito anteriormente que cada manifestação de um sujeito dentro de um processo gerava no plano comportamental do outro uma reação, que por sua vez, após agir, causava o mesmo efeito ativo no adversário e/ou no juiz. Naquela oportunidade se estava tratando do plano relacionado aos interesses das partes e suas atuações no cenário processual. Entretanto, pode-se observar pela ótica formal um fenômeno bastante parecido: adotada uma posição por um dos sujeitos processuais, nasce aí uma nova posição dirigida a outro sujeito, que, superada, gera uma terceira posição e assim sucessivamente. Segundo a doutrina, essa força motriz que faz o processo avançar chama-se preclusão. ${ }^{364}$

\footnotetext{
${ }^{362}$ TARUfFO, Preclusioni (diritto processuale civile) (voce), in (stratto) Enc. dir., Agg. I, Milão, 1997, p. 974.

${ }^{363}$ Nesse sentido, SICA, Preclusão, cit. p. 96. Não se está aqui, por certo, entrando na polêmica temática do conceito de processo como relação jurídica, que sofreu por parte da doutrina intensas críticas. Assim, ELIO FAZZAlari, Istituzioni di Diritto Processuale, Padova, 1989, pp. 73 e ss.; CRISANTO MANDRIOLI. Corso di Diritto Processuale Civile, Torino, 1989, pp. 40-41, para quem tal idéia é insuficiente, não obstante o reconhecimento da importância do conceito para a autonomia do processo como ciência. Tampouco se está teorizando qual a correta interpretação para a expressão 'relação jurídica processual'; por todos, pela clareza e profundidade, MARINONI, Da teoria da relação jurídica processual ao processo civil do estado constitucional, $\quad$ in $\quad$ http://www.abdpc.org.br/abdpc/artigos/Luiz\%20G\%20Marinoni(8)\%20\%20formatado.pdf, acessado em 10/12/2013. O que se faz, ao contrário disso, é tão somente menção às posições jurídicas adotadas pelos indivíduos, em especial os sujeitos principais do processo, ao longo do procedimento.

${ }^{364}$ Por todos, SICA, Preclusão, cit. 96.
} 
As citadas posições podem ser de dois tipos, a saber: as ditas passivas, responsáveis por colocar o indivíduo em uma situação de sujeição, e as chamadas ativas, que atribuem ao agente uma condição de atuar na esfera jurídica de outrem com a produção de um determinado ato. São, em outros termos, situações que deixam os sujeitos processuais em posições de vantagens e desvantagens. ${ }^{365}$

Em relação às posições ativas assumidas, em específico, pelas partes - e adotando as observações bem como a estruturação teórica de HEITOR SICA -, destaca-se um ponto fundamental para o desenvolvimento do raciocínio: o exercício de posições dessa natureza visa ao atendimento da satisfação dos interesses próprios do agente; o sujeito que as exerce tem a si assegurada uma vantagem, que pode ser maior ou menor a depender do caso, em busca da tutela jurisdicional favorável e, por conseqüência, do bem jurídico pleiteado. ${ }^{366}$

Norteando-se por esse raciocínio, o citado autor define o ônus, representante dessa categoria de posição jurídica, como sendo o imperativo do próprio interesse, conceituação, de resto, que aponta como sendo assente tanto na doutrina material como também na processual $^{367}$. Contudo, destaca que por essa perspectiva, simplesmente, não se poderia fazer diferenciações entre as faculdades, também representante das posições jurídicas ativas, e os ônus. Observa que se o núcleo do conceito deste é o atendimento do próprio interesse, se diferenciando, assim, das obrigações, não haveria qualquer sentido colocá-lo em contraposição à faculdade, pois nela o agente também age visando interesses seus. ${ }^{368}$

Trazendo o problema para a órbita do processo, o doutrinador vincula o conceito de ônus ao de preclusão. O inadimplemento dos ônus, mais do que uma simples ausência de obtenção de uma posição de vantagem (caráter ativo dessa posição), acarreta a "perda da possibilidade de realizar a atividade processual" (preclusão) ${ }^{369}$. Desse modo, a faculdade

${ }^{365}$ SICA, ibidem, p. 97; DINAMARCO, Instituições, cit., p. 201.

${ }^{366}$ SiCA, em seu trabalho, além do ponto destacado, toma como premissa outras duas asserções para enfrentar o tema da preclusão. São elas: que o poder de exigir um determinado comportamento de alguém não é ilimitado, mas restritos aos exatos termos normativos e que o sistema processual dá a escolha aos sujeitos parciais do processo de exercerem, caso assim desejem, suas posições de maneira diversa daquela prevista em lei, mas sendo-lhes imposta uma conseqüência negativa. Nesse sentido, Preclusão, cit., p. 98. Para o trabalho, destacou-se a primeira premissa pela relação desenvolvida com o posicionamento epistêmico até aqui adotado.

${ }^{367}$ SICA, ibidem, p. 99.

${ }^{368}$ Idem, ibidem. Para o autor, a posição epistêmica dos litigantes é elemento fundamental para o tema da preclusão.

${ }^{369}$ SICA, ibidem, p. 100. O autor, com muita clareza, assim se manifesta: "O adimplemento do ônus se dá não só porque a parte almeja a obtenção de vantagem, em atendimento ao interesse próprio, mas também porque 
se diferencia do ônus não pelo exercício do próprio interesse ou pela vantagem adquirida após o seu adimplemento - características, de resto, perceptível em ambas as posições-, mas pela ausência de preclusão a ela vinculada em caso de não cumprimento do ato.

Em relação às posições passivas assumidas pelas partes, cita o referido processualista como representante dessa espécie os chamados deveres, que representam aos agentes do processo uma sujeição. Quer para atender a um interesse público, quer para atender um interesse alheio, não cabe à parte escolher se irá ou não adimpli-la: a cada omissão lhe será cominada uma sanção.

Os deveres, desse modo, diferenciar-se-iam dos ônus na medida em que: a) da ausência de prática do ato adviria uma sujeição a uma obrigação, não apenas uma perda de uma posição favorável; b) a posição desfavorável do sujeito que se encontra nessa posição, no caso do ônus, somente adviria se ele não cumprisse com o estipulado, ao passo que a desvantagem, ao se tratar dos deveres, existe antes do próprio ato a ser produzido (no caso de cumprimento, apenas não lhe será imposta a sanção); c) os deveres visam a efetivar interesses públicos ou de terceiros, tal como afirmado, e os ônus, diferentemente disso, aos interesses do próprio sujeito; e d) os deveres, caso não adimplidos, continuam existindo e a parte obrigada continua sujeita ao seu cumprimento, ainda que fora do tempo e da forma originalmente previstos pela lei, ao passo que sobre o inadimplemento do ônus sobrevém uma preclusão impedindo a produção do ato previsto. ${ }^{370}$

No que tange aos posicionamentos jurídicos do juiz, ressalta-se que esse sujeito processual somente assume uma única posição: o poder-dever, por meio da qual sujeita as partes aos seus poderes, tudo conforme o direito positivo, em busca do resultado final: a decisão. $^{371}$

No que tange ao objeto desse estudo - depois de fixadas, ainda que de forma superficial, algumas premissas conceituais-, cabe perquirir qual seria, diante de todas as características epistemológicas das manifestações das partes e da formação do juízo, a melhor disposição pela lei das posições jurídicas estipuladas aos sujeitos processuais, em

quer ela evitar a desvantagem decorrente da preclusão, isto é, a perda da possibilidade de praticar determinado ato processual”, e conclui: “Assim, só existe ônus se houver preclusão”, p. 101.

${ }^{370}$ SICA, ibidem, p. 105.

${ }^{371}$ Idem, ibidem. 
específico autor e réu, em relação à atividade enunciativa (de fato e de direito) e à formulação de pedidos.

Quanto ao tema, nota-se que o legislador, dentro de todo o arco procedimental, poderia dispor de incontáveis maneiras das distribuições de ônus, faculdades e até mesmo deveres processuais entre as partes, constituindo um sistema mais ou menos rígido a depender da estrutura adotada.

Considerando o caráter meramente informativo do conteúdo da inicial, abandonando-se o método identificativo e observando os conceitos de preclusão e de modificação da demanda acima expostos, buscar-se-á traçar uma proposta estrutural que atribua ao instituto modificativo caráter de potencialidade funcional em busca de uma tutela justa. É o que se passa a fazer

\subsection{Proposta de releitura do instituto modificativo - uma nova função}

Por tudo o que foi dito até aqui, necessário se faz repensar o instituto modificativo, dando a ele uma potencialidade até então ignorada (ou mesmo esquecida). Como elemento norteador dessa proposta de raciocínio, tomar-se-á como elemento o fenômeno identificado pela doutrina como "demanda sem resposta" "372 - expressão essa já utilizada em momentos precedentes dessa dissertação.

No âmbito do raciocínio lógico geral, é possível afirmar que uma resposta correta pressupõe uma pergunta também correta. Em outros termos, o emissor de um questionamento, para que possa obter a resposta justa de seu interlocutor, deverá formular seu enunciado interrogativo da maneira mais precisa possível, sob pena de ter como retorno um conteúdo informativo não condizente com sua intenção questionadora.

As afirmações feitas acima encontram seu suporte teórico em estudos desenvolvidos sobre o tema em campos extrajurídicos, mais precisamente no da semântica,

\footnotetext{
${ }^{372}$ A expressão é de EnRIQUES, Do Corporate Law Judges Matter?, cit. pp. 765 e ss; ID., Il nuovo diritto societario nelle mani dei giudici: una ricognizione empirica, in Stato e mercato, 2001, I, pp. 79 e ss.. Enfrenta o tema da modificação considerando o fenômeno GAMBA, Diritto societario, cit. pp. 157 e ss.
} 
do pragmatismo lingüístico e da epistemologia, que buscam estipular as relações existentes entre perguntas e respostas. ${ }^{373}$

Do ponto de vista semântico, uma pergunta configura uma requisição de informação quanto a uma determinada situação. Especificar corretamente qual é essa informação é fundamental para que o conteúdo da resposta seja satisfatório aos fins desejados. Em uma pergunta como “quem é Brás Cubas?”, espera-se uma enunciação de consciência do interlocutor que corresponda à demanda, isto é, há um desejo por parte de quem formula a questão de que a resposta tenha como conteúdo algo como "eu sei quem é Brás Cubas". Esse elemento da indagação que delimita a expectativa da resposta é chamado desideratum. ${ }^{374}$

Ocorre, porém, que esse não é o único componente de uma interrogação. Há, outrossim, aquilo que a doutrina chama de pressuposição da questão ${ }^{375}$. Em outra pergunta exemplificativa, tal como "por que Capitu traiu Bentinho?", pressupõe-se que Capitu tenha mesmo traído Bentinho, querendo o demandante saber as razões para a conduta de infidelidade. Referente a este elemento, deve-se ressaltar que, para que a pergunta possa ser satisfatória, a pressuposição deverá obrigatoriamente ser verdadeira. Uma indagação do tipo “por que você não para de fumar?” dirigida a um não fumante, como é óbvio, não terá uma resposta confluente ao objeto esperado pelo indagador.

No que tange ao processo, fazendo-se uma translação daquelas idéias, a mesma lógica formal deve ser aplicada: para que um juiz possa emitir uma sentença correta ao caso, deveria ele receber uma demanda formulada da forma mais correta possível.

A afirmação acima, como é facilmente perceptível, parte de uma visão interpretativa do conceito de processo como instrumento de pacificação social com justiça. Se assumido o ponto de vista para o qual o processo tem como escopo atribuir àquele que tem razão uma tutela efetiva de seus direitos (isto é, uma decisão justa), simetricamente é

${ }^{373}$ Exemplo interessante desses estudos é: JAAKKO HINTIKKA e MERRIL B. HinTIKKA, Sherlock Holmes e la lógica moderna: verso una teorizzazione della ricerca di formazione attraverso domende, Giampaolo Proni (trad.), in Eco, Sabeok (a cura di), Milão, 2000, pp. 185 e ss., especifica e esquematicamente pp. 187-189.

374 GAMBA, Domande, p. 151.

${ }^{375}$ HINTIKKA, Sherlock Holmes e la lógica moderna, cit. p. 188. 
possível afirmar que os pressupostos ideológico-funcionais devem, outrossim, orientar a articulação da demanda no cenário processual. ${ }^{376}$

Alguém que aceita uma resposta aleatória e sem qualquer elemento de justiça material por parte do juiz sequer se propõe a enfrentar o problema da relação de conteúdo entre demanda e decisão.

Diante disso, conforme fora analisado no item 3.1. retro, tomou-se como conteúdo para decisão justa aquela tida como a melhor escolha dentre todas as possíveis, escolha essa que deve ter como baliza três critérios, quais sejam: a) que a decisão seja fruto de um procedimento desenvolvido de maneira justa e válida; b) que ela venha fundada em enunciados sobre fatos relevantes legitimamente comprovados como verdadeiros, isto é, sobre asserções fáticas importantes que tiveram um reconhecimento de veracidade de seus conteúdos, os quais poderão apontar com segurança e maior clareza os limites complexos do conflito; e c) que seja uma decisão fundada sobre a escolha e a interpretação corretas das normas aplicáveis ao caso concreto.

Como fora ali afirmado, esses critérios são parâmetros gerais, e não conceitos rígidos e pré-definidos. São, outrossim, contextuais. Afirmar que uma interpretação está correta, que o procedimento foi justo ou que os enunciados sobre os fatos foram legitimamente comprovados como verídicos, por exemplo, só é possível ao se relacionar as escolhas feitas ao contexto em que foram feitas. ${ }^{377}$

Uma demanda judicial que visa a obter uma resposta justa dentro dos critérios acima apontados, em tese, deveria ser fundada sobre os mesmos requisitos de justiça da decisão, ou seja, deveria tendencialmente ser fundada sobre afirmações verdadeiras e completas dos fatos sobre os quais sustenta a insatisfação, além de ser formulada baseada em uma roupagem estrutural jurídica na qual haveria um apontamento de uma correta aplicação do direito ao caso concreto. Em teoria e em abstrato, uma demanda que integrasse perfeitamente os requisitos apontados teria as condições ideais para uma pronúncia de uma decisão informada pelos três parâmetros de justiça ${ }^{378}$. Uma demanda

\footnotetext{
376 Nesse mesmo sentido, GAMBA afirma que: "la risposta del processo come strumento di tutela giurisdizionale è tanto più correta quanto più tende ad integrare completamente i requisiti della decisione giusta: simmetricamente, la domanda è tanto meglio articolata quanto più pone le condizioni per ottenere una risposta che rivesta le caratterische di giustizia", ibidem, cit. p. 149.

${ }^{377}$ Para maiores aprofundamentos, com várias referências bibliográficas, vide item 3.1. Critérios para uma decisão justa, retro.

${ }^{378}$ Em sentido idêntico, GAMBA, Domande, cit. pp. 150-151.
} 
corretamente formulada teria muito mais chances de obter uma resposta justa que aquela mal estruturada.

Entretanto, como incansavelmente se descreveu no capítulo II, retro, a demanda proposta pelo autor por meio do seu ato introdutório se funda em enunciados de fato e de direito subjetivamente construídos, direcionados à vitória, potencialmente falsos e que representam apenas a parte que lhe favorece da realidade, sendo, pois, parciais e incompletos.

As características da peça introdutória, porém, não obstante divirjam dos requisitos exigidos para uma resposta correta e justa, não anulam a lógica formal semântica aplicada ao processo da pergunta correta/decisão correta. A articulação de novos enunciados fáticos e jurídicos ao longo do procedimento, além de formulação de novos pedidos, configuraria justamente o 'ajustamento do tiro', possibilitando uma formação representativa da crise mais completa e dando ao julgador maiores chances de uma correta escolha normativa, tendo como conseqüência uma maior probabilidade de que sentença seja mais justa possível. $^{379}$

Poder-se-ia objetar o que se disse alegando que os novos enunciados de fato e de direito, bem como os pedidos, seriam igualmente estruturados de maneira subjetiva, além de os primeiros apresentarem as mesmas características de incompletude, parcialidade e potencial falsidade dos elementos trazidos com a inicial, indo de encontro, pois, com as premissas de toda a construção.

Tal objeção não é privada de razão. Ocorre, porém, que o uso do instituto modificativo pelas partes deverá ser exercido sob o controle do juiz. Será ele - o responsável por formular a resposta- que irá controlar quais serão os limites das atividades dos sujeitos parciais. É em um cenário controlado por alguém destacado que o instituto da modificação da demanda será posto em ação.

Traçadas algumas linhas gerais da proposta, na qual a atividade modificativa tem a função instrumental de atribuição de qualidade à demanda e, ulteriormente, à sentença, sempre se pautando pelos requisitos de justiça da decisão, resta agora analisar em apartado como isso se daria individualmente com cada um dos "cânones de justiça".

${ }^{379}$ GAMBA, ibidem, pp. 155-156. 
4.2.1. A modificação da demanda, a verdade e a completude dos enunciados representativos.

A proposta de dar um potencial funcional ao instituto da modificação da demanda, conforme fora proposto, toma as condições de justiça da decisão com ponto de partida. A modificação passa a ser o elo entre a pergunta e resposta, isto é, entre a demanda e a sentença.

Tal como foi dito anteriormente, o advogado do autor propõe na peça inicial alguns enunciados fáticos que possuem como objeto acontecimentos relevantes para a tese jurídica por ele sustentada. A relevância desses fatos é dada tomando-se como base normas com as quais o patrono do autor envolveu a insatisfação de seu cliente para entrada da crise em juízo. Esses fatos, segundo toda construção teórica jurídica, são denominados fatos constitutivos do direito do demandante. Outros enunciados referentes a fatos secundários e até mesmo irrelevantes também compõem o conjunto enunciativo do ato introdutório.

O réu, por seu turno, ou nega a veracidade dos enunciados trazidos pelo autor, e/ou traz consigo enunciados que têm como objeto fatos também principais, mas de cunho extintivo, modificativo ou impeditivo do direito alegado. Pode, ademais, formular narrações sobre fatos constitutivos aptos a embasar uma pretensão reconvencional.

Todos esses enunciados possuem natureza hipotética e caráter incerto sob uma perspectiva epistemológica: são, em regra, apofânticos e o estado de incerteza quanto a eles só virá eliminado com a decisão, mais precisamente com juízo fático. ${ }^{380}$

A relevância dada dentro da inicial aos fatos narrados também é meramente hipotética. As partes constroem os enunciados colocando como hipótese uma qualificação jurídica dos acontecimentos e afirmando a aplicabilidade ao caso concreto de uma ou mais normas jurídicas. Cada parte, em outros termos, propõe ao juiz uma própria conjectura de thema probandum da controvérsia, indicando aquele que, segundo eles, deveria ser o

\footnotetext{
${ }^{380}$ Da mesma forma, apenas a título exemplificativo, sem pretensão de exaurimento e com ampla indicação bibliográfica: TARUFFO, Prova (in generale), cit., pp. 3 e ss, especificamente pp. 8, 9 e 10; ID., Prova giuridica, cit., pp. 1019 e ss; ID., Considerazioni su prova e verità, cit., pp. 277 e ss.
} 
conteúdo da decisão ${ }^{381}$. Contudo, tais estruturações jurídicas são somente sugestivas e não possuem o condão de vincular o juiz.

Não bastasse tais características dos elementos da inicial, cada enunciação feita pelas partes carrega em si uma pretensão de veracidade: eles são formulados na inicial e contestação (de resto, na reconvenção, réplica e outras manifestações) como se verdadeiras fossem. Como fora dito, não se pode imaginar, sem que isso cause qualquer incômodo, a existência de enunciados sem qualquer intenção de serem verdadeiros formulados no bojo de um processo. Um cenário jurídico exige, pelo menos se as partes buscam agir coerentemente em busca de seus escopos, que se construam enunciados verossímeis afirmados verdadeiros ou propriamente verdadeiros. ${ }^{382}$

Disse-se, igualmente, que pela perspectiva epistemológica os fatos não são entidades simples, homogêneas e analiticamente definidas. Ao contrário disso, há em suas bases uma variedade de circunstâncias, tais como tempo, espaço, temperaturas, pressão, som, cores, comportamentos dos envolvidos, dentre tantas outras, que formam o fato em si como entidade complexa.

Desse modo, não existe uma única narração apropriada daquele fato, mas sim um sem número de enunciações verdadeiras sobre ele, bem como infinitas asserções falsas ${ }^{383}$. O mesmo evento, ademais, pode ser narrado e analisado por diversos níveis: do micro (genes, partículas, moléculas, átomos) ao macro (acidente). Entre tais extremos, há um espectro infinito - ou quase infinito - de níveis intermediários, muitas vezes interligados entre si (uma análise química, por exemplo, referente a um desastre ecológico, avaliandose, em seguida, os danos econômicos daí advindos). ${ }^{384}$

Destarte, o fato é algo bastante complexo, muito distinto daquela representação reduzida e simplificada que, em geral, se utiliza a doutrina processual, que o menciona como se o evento real possuísse caráter nítido e analiticamente definido.

\footnotetext{
${ }^{381}$ Nesse sentido, GAMBA, Diritto societario, cit. pp. 405-406, 411 e ss.; ID., Domande, cit., pp. 176 e ss.; TARUFFO, Elementi per um'analisi, cit., pp. 242 e ss.

${ }^{382}$ Para aprofundamentos, vide item 2.3. Das narrativas em geral. Na doutrina, ver: TARUFFO, Narrativas judiciales, cit., pp. 238 e ss.

${ }^{383}$ Conforme já citada, SUSAN HAACK, Manifesto of a passionate moderate, cit. pp. 157 e ss. Igualmente, TARUFFO, La semplice verità, cit. p. 197.

${ }^{384}$ Todo o processo de decomposição qualitativa e quantitativa de um fato, bem como os vários tipos de construção de enunciados (seletivo, semântico, institucional etc.), vide item 2.4.1. Da construção dos enunciados fáticos. No mesmo sentido do texto, GAMBA, Domande, pp. 163-164.
} 
Tais observações demonstram que as hipóteses fáticas (enunciados propostos pelas partes quanto aos fatos) são parciais, subjetivas, incompletas e direcionadas à obtenção de um interesse em específico, qual seja, o desejo de vitória que guia as condutas de quem os formulou (rectius: dos clientes de quem os construiu). Logo, as hipóteses fáticas trazidas pelos sujeitos, por sua própria natureza, não são idôneas a conduzir a uma individuação dos acontecimentos que compõem a controvérsia conforme os requisitos de justiça. A realidade do conflito vem mutilada, quer em seu perfil qualitativo, quer em sua face quantitativa, pelo interesse e pela estratégia das partes no processo.

Se a verdade dos fatos é uma condição para a decisão justa, então o instituto da modificação - ponte, como se disse, entre a demanda e a correta resposta - deveria se pautar por uma variação potencialmente idônea a conduzir a uma maior veracidade do conjunto enunciativo em si.

Levando-se em conta a incerteza epistemológica das narrações trazidas pelas partes, dever-se-ia abrir para elas momentos para que pudessem fazer intervenções ulteriores sobre os mesmos enunciados. A mesma possibilidade intervencionista modificativa deveria ser possível quanto às qualificações jurídicas inicialmente estruturadas, bem como para alterar a relevância fática tida com a configuração normativa inicial, tudo visando a adaptar o conjunto narrativo à realidade da crise.

Nesse sentido, considerando também a questão da parcialidade e incompletude dos enunciados, a modificação serviria para dar a oportunidade aos indivíduos envolvidos para formularem novas narrações, que seriam capazes de recuperar um grau de atendibilidade da representatividade dos enunciados, aumentando-se o grau de compatibilidade entre as asserções e a realidade e, com isso, melhorando o material sobre o qual recairá o juízo do magistrado.

Tais possíveis alterações teriam, potencialmente, o escopo de aportar ao cenário das manifestações introdutórias um melhoramento sob um prisma qualitativo. Entretanto, como é notório, não seriam suficientes, em regra, para garantir uma demanda 'mais correta'. Como fora dito, deverá haver um controle para que se evite o efeito degeneratório dos atos modificativos.

Um segundo elemento que compõe o requisito de justiça relacionado à verdade é o da completude ou 'determinação idônea dos fatos a representar a complexidade do conflito 
como um todo ${ }^{385}$. Como se pode ver, a chamada completude da representação processual, relacionada com o critério da veracidade necessária, apresenta algumas conotações extras importantes.

Ela configura uma 'verdade alargada' referente à unidade dos fatos objetos da reconstrução processual. Quanto maior for o grau de completude (lembrando, sempre, que a completa representação é algo impossível devido a todas as características epistemológicas já apontadas do ato narrativo), maior será a capacidade de atribuir ao juiz uma representação satisfatória dos reais limites do conflito.

É de fácil ilação, portanto, concluir que não é suficiente que os enunciados fáticos destinados compor a base da decisão sejam verdadeiros: verdadeira deve ser a reconstrução, em sentido de completude, das circunstâncias reais que originaram o conflito entre os sujeitos. ${ }^{386}$

Essa visão se aproxima bastante do conceito sociológico de lide que formulou FRANCESCO CARNELUTTI, apresentando consigo três dimensões importantes: a) um aspecto empírico do conflito, no qual há uma prevalência da dimensão do comportamento, tomamse em consideração circunstâncias reais dispostas no tempo e no espaço, as quais determinam a causa ou motivação; b) a dimensão das percepções, o que possibilita considerar, outrossim, o ponto de vista subjetivo de cada qual quanto ao conflito; e c) a contradição de fundo em si, aproximando-se, pois, da própria configuração da problemática real. ${ }^{387}$

Conforme se crê, observando-se, sempre, os limites legais, para que se possa haver a sentença mais justa possível, necessário olhar a controvérsia entendendo-a como 'uma contraposição entre sujeitos entorno a posições de interesse com relevância jurídica, inserida no mais amplo contexto conflitual pertencente ao plano fenomenológico envolvendo indivíduos ${ }^{388}$. A melhor demanda, no sentido sociológico, é aquela que visa a obter uma resposta jurisdicional capaz de resolver a situação conflitual em sua completude, isto é, em sua inteireza.

${ }^{385}$ GAMBA, ibidem, p. 166.

${ }^{386}$ EnRIQUes, Do Corporate Law Judges Matter?, cit. pp. 771 e ss.; GAMBA, Diritto societario, pp. 301 e ss.

${ }^{387}$ Nessa mesma linha de raciocínio, GAMBA, Domande, cit. p. 169, em específico na nota 34, na qual traz traços da discussão teórica entre Calamandrei e Carnelutti sobre lide parcial e lide total, já referida anteriormente nas linhas do presente trabalho.

${ }^{388}$ GAMBA, ibidem, pp. 172-173. 
Quanto a esse perfil, frise-se que um processo capaz de resolver grande parte do conflito é coerente com o princípio da economia processual externa, evitando-se, com ele, a multiplicação de demandas sobre o mesmo problema social.

O instituto modificativo, portanto, serviria, se analisado pelo requisito da verdade, para: a) dar abertura a novas formulações de enunciados que tragam mais fatos importantes, ante-fatos ocultados e novas perspectivas fáticas antes não destacadas pelo narrador, tudo a fim de atribuir à representação processual uma maior amplitude do conflito, tornando-a mais coerente com os reais limites da crise; e b) ampliação da requisição de resolução (novos pedidos) para uma tutela jurisdicional capaz de abranger a maior área das insatisfações do plano concreto.

Além dos perfis acima destacados, é fundamental que a representação do conflito feita pelos advogados das partes seja completa para evitar o fenômeno da 'demanda sem resposta'. Em muitos casos é possível perceber que os limites da base enunciativa trazida aos autos pelas partes é muito aquém dos reais contornos da crise. Podendo se manifestar somente dentro dos confins estipulados pelos sujeitos parciais do processo, sendo vedado a ele o uso do conhecimento privado, o juiz emitirá uma decisão completamente descolada da realidade. A manutenção da coesão entre a resposta e a reprodução formal do conflito faz com que a sentença dada pelo Estado não satisfaça o real anseio da pergunta feita pelo jurisdicionado.

As causas para o fenômeno apontado podem ser de várias naturezas, tais como estratégia mal calculada pelo advogado, incapacidade técnica, limitações narrativas, dentre tantas outras que causam uma deformação redutiva do conjunto enunciativo representativo. Todavia, em regra, a demanda com limites inferiores e com grau de representação da crise insatisfatório pode ser notada quando à base da insatisfação encontram-se fatos complexos. Por apresentar inúmeros micro-fatos unitários que se protraem no tempo, há limitações narratológicas extras que fazem com o cenário representativo processual deixe de lado grande parte da face do conflito. Em outros termos, uma enorme porção da crise resta fora dos limites jurisdicionais do processo pela incapacidade reprodutiva exauriente da atividade narrativa inicial, parte essa que pode ser decisiva para que a insatisfação dos 
indivíduos seja entendida em sua inteireza e a resposta do órgão julgador seja satisfatória à sua resolução. $^{389}$

Também por essa perspectiva as modificações dos enunciados de fato e de direito poderão contribuir com o requisito da completude e inteireza do conjunto enunciativo, atribuindo maiores possibilidades de um julgamento com qualidade.

É de se ressaltar, mais uma vez, que toda essa atividade modificativa deve ser exercida com o controle daquele que deverá realizar o juízo de fato e de direito, isto é, o juiz.

\subsubsection{A modificação da demanda, a dialética entre as partes e o justo} procedimento

Disse-se no item anterior que a correspondência entre a realidade do conflito e a configuração representativa da crise no processo é um dos pressupostos indispensáveis para uma sentença justa. $\mathrm{O}$ correto acertamento dos acontecimentos, tanto em veracidade como em extensão, é pressuposto para que se possa chegar à decisão mais correta possível. Se assim o é, levando-se em consideração a dinâmica processual, então a manutenção de uma 'estrada aberta' em direção a um possível 'aperfeiçoamento do tiro' é um meio bastante útil para corrigir as distorções redutivas dos enunciados inicialmente formulados. Abrindo-se caminho para uma possível modificação, afasta-se (ou diminui-se) o risco de cristalização da demanda imperfeita em relação à base de fato e de direito, evitando-se com isso a possível indiferença da decisão.

\footnotetext{
${ }^{389}$ Para maiores aprofundamentos quanto aos fatos complexos e os impactos que sofre a decisão pela porção do conflito que não entra no processo, com citações de casos reais apreciados pelo judiciário brasileiro, ver itens 2.4.1.1., Da incompletude e parcialidade dos fatos trazidos com o ato introdutório, e 2.4.1.2., $O$ fato e sua complexidade. GAMBA, Diritto societario, cit., pp. 157 e ss, traz interessantíssimas observações sobre a indiferença da decisão em relação a inteireza do conflito existente à base de crises societárias. A autora faz comparações entre a Corte de Milão, que muitas vezes, por ignorar a perspectiva epistemológica do ato narrativo, limitava sua decisão à estrutura formal de causa de pedir-pedido construída na inicial, gerando respostas, muitas vezes, completamente insatisfatórias, pois descoladas da realidade do conflito. Por outro lado, a doutrinadora traz casos julgados pela Court of Chancery do Estado de Delaware em que juízes levavam em consideração toda a porção do conflito que não entrara no cenário processual, dando às insatisfações uma resposta mais que satisfatória, dava-se uma resposta correta segundo os critérios de justiça da decisão por evitar a indiferença quanto à controvérsia. Apontando para o mesmo fenômeno, também com ampla análise de julgados na Itália, ENRIQUES, Do Corporate Law Judges Matter?, cit. pp. 800 e ss.; ID., Il nuovo diritto societario nelle mani dei giudici, cit., pp. 81 e ss.
} 
Não obstante as vantagens apontadas acima, importante notar, segundo a classificação de posições jurídicas feita anteriormente, que, em geral, a modificação da demanda é tida, pelo menos no sistema positivo atual, como um ônus: caso não exercitada no momento justo, abate-se sobre a atividade enunciativa das partes uma preclusão que as impedem de exercer alterações ulteriores em suas representações. Algumas considerações mais profundas sobre os sistemas postos serão traçadas no capítulo subseqüente. Para o momento, porém, parece ser importante destacar que em uma estrutura aberta e controlada pelo juiz atribui aos litigantes uma faculdade modificativa, jamais um dever. Primeiro pelo simples fato de que autor e réu somente modificarão suas asserções em interesse próprio; o interesse público de completude e veracidade, não obstante seja uma nova perspectiva de encarar o tema, é apenas um reflexo importante daquela conduta privada. Ademais, cobrar que as partes adimpliam essa obrigação de alteração dos enunciados parece algo de difícil aplicação e controle práticos.

Disso, surgem alguns problemas: a) sendo uma faculdade, não haverá qualquer garantia de que os sujeitos parciais do processo irão, ao modificar seus enunciados fáticos e jurídicos, trabalhar para configurar uma melhor representatividade do cenário por eles construído, dando ao conjunto assertivo inicial maior completude e veracidade (os novéis enunciados terão as mesmas características epistemológicas de parcialidade, incompletude e potencialidade falsa); b) a atividade modificativa poderá, por essa ótica subjetiva, levar a uma modificação que 'piore' a qualidade da representação, tudo a depender das estratégias direcionadas e interessadas das partes.

O contraditório é uma importante ferramenta de controle. Submeter as enunciações novas à análise da contra parte, mais do que um mero cumprimento de um dispositivo procedimental, parece ser uma prática de controle e avaliação sobre a qualidade e funcionalidade da atividade exercida em concreto. Entretanto, somente o contraditório em si não é suficiente para garantir que as alterações no conjunto narrativo sejam destinadas à completude e à veracidade: as partes, como é próprio da natureza de suas posições epistemológicas, agem em seus próprios benefícios e em busca da vitória e não da verdade - salvo, evidentemente, se essa lhes beneficiar. Tampouco buscam a tutela justa, mas sim aquela que lhes seja favorável.

O contraditório é importante para ampliar o conhecimento relativo ao conflito, mas versões parciais e incompletas deixam lacunas. Logo, a atividade modificativa não pode 
ser exercida em um cenário de total liberdade, mas, ao contrário disso, deve desenvolver-se em um âmbito controlado.

Sem comprimir a atuação expressiva dos participantes e garantindo o exercício do contraditório, o juiz, nessa estrutura, faria o papel de guia, que, ao colaborar com o seu poder-dever de direção material do processo, ajudaria a conduzir o melhoramento do objeto do juízo de fato que estará à base da decisão.

As hipóteses fáticas construídas pelo juiz, por seu turno, apresentam características diferentes daquelas construídas pelas partes. O juiz tem o trabalho de dizer se há ou não uma posição jurídica favorável - se subsistem ou não os pressupostos de acolhimento da demanda-, dando ou não os provimentos de tutela requeridos.

O juiz age, pois, sem interesse em relação ao êxito da demanda. Age, ao contrário, interessado na descoberta da verdade e na correta aplicação das normas ao caso concreto. Assim, as hipóteses formuladas pelo magistrado se revestem de imparcialidade, forte caráter de objetividade, completude e inteireza da representação do conflito. ${ }^{390}$

Por essas suas características epistemológicas, o julgador deve adotar uma postura ativa a fim de recuperar a completude e buscar uma veracidade das representações parciais, tudo com o intuito de cumprir com seu papel institucional.

A chamada terzietá e imparcialidade ganham, diante dessa visão, uma nova roupagem. Sobre o ponto, importante destacar algumas pontos de interesse. Parte da doutrina afirma que uma postura ativa do juiz poderia levar a eqüidistância do magistrado em relação às partes ao fracasso. As movimentações do juiz acabariam por comprometer a isenção frente aos interesses dos litigantes. ${ }^{391}$

Ademais, a combinação dessa postura não estática com o aumento dos poderes do magistrado poderia aumentar as chances de um eventual favorecimento a um dos contendores. Por essas razões, um comportamento ativo seria extremamente temerário para a imparcialidade do julgador frente às questões e partes que se encontram diante dele.

\footnotetext{
${ }^{390}$ TARUFFO, Elementi, cit. pp. 240 e ss.

391 Como exemplo, MonTero Aroca, El proceso civil llamado 'social' como instrumento de 'justicia' autoritaria, cit., pp. 141 e ss.; CIPRIANI, L’autoritarismo processuale e le prove documentali, cit. pp. 289 e ss.; CORREIA DE MENDONÇA, Virus autoritario e processo civil, cit., pp. 115 e ss.; GIANFRANCO RICCI, Questioni controverse in tema di onere della prova, cit., pp. 321 e ss.
} 
As afirmações de que essa postura ativa desequilibraria as posições das partes e de que o juiz poderia se utilizar das alterações enunciativas para extrapolar os limites desejáveis de imparcialidade parece se consubstanciar em argumento arenoso. Um juiz interessado na causa, buscando favorecer uma ou outra parte, não necessitaria desse poder para alcançar seu desiderato. Independentemente dos limites do conjunto representativo apresentado, até mesmo nos sistemas mais rígidos quanto à modificação da demanda, estando o magistrado mal intencionado, poderá ele proferir julgamento tendencioso quer com poderes quer sem poderes amplos de iniciativa. É inaceitável que um ente estatal designado para a solução da controvérsia aja dessa maneira. Mas certamente não será tolhendo poderes de gerência sobre o conteúdo representativo que se evitará decisão parcial.

Aliás, foi justamente pensando nisso que o ordenamento ofereceu mecanismos aos jurisdicionados a fim de corrigir essas mazelas. A título de exemplo, citam-se os recursos, a ação rescisória, órgãos de controles internos (corregedorias) e, principalmente, a previsão dos institutos do impedimento e da suspeição trazidos pelos arts. 134 e ss do CPC.

Reconhece-se, claro, a possibilidade da existência no plano concreto de eventuais distorções desse poder. Negá-los em sua integralidade é pura ingenuidade. Entretanto, desmandos, abusos e julgamentos injustos devem ser encarados como exceção à regra, e não como algo constante no sistema, devendo ser combatido pelos instrumentos postos e direcionados a esse objetivo.

Portanto, o argumento e o medo que apontam para eventuais abusos estatais não mais se coadunam com a visão moderna de processo, que tem em si a idéia inerente de pacificação social por meio de uma tutela justa. ${ }^{392}$

No que se refere ao princípio da imparcialidade do juiz, entendido como a eqüidistância entre ele e as partes, não se pode alegar que o eventual aumento do poder do magistrado e sua postura ativa interfeririam na sua 'neutralidade'. Cabe aqui apontar

\footnotetext{
392 Notórios são os ensinamentos da professora ADA PELLEGRINI GRINOVER sobre como deve ser a consciência e a formação dos juízes. Em resposta à pergunta que ela mesma propõe de como reverter o quadro de magistrados burocratas e "encastelados em posições de gabinete que pouco ou nada têm a ver com a realidade social", alega "tem-se salientado que o acesso à ordem jurídica justa pressupõe um corpo adequado de juízes, com sensibilidade para captar a realidade social e suas vertiginosas transformações. E que isso postula a exigência da mudança da mentalidade do juiz, inserido que há de ser no corpo social e comprometido com o objetivo de realização da justiça material”, O Processo em Evolução, Rio de Janeiro, 1996, p. 25.
} 
algumas distinções de relevo. A primeira delas é que juiz 'neutro' não é sinônimo de juiz passivo $^{393}$. Tampouco o é de juiz desinteressado.

É justamente por misturar os três termos que parte da doutrina conclui que juiz ativo é equivalente a juiz parcial. Entretanto, pode-se afirmar que a parcialidade está relacionada com o interesse do juiz psicologicamente envolvido com uma das partes. Em outras palavras, magistrado maculado com a parcialidade é aquele que tem suas intenções voltadas a beneficiar um indivíduo litigante no mérito da demanda. Há uma congruência entre o interesse do julgador e o interesse de uma das partes, isto é, do litigante preferido.

Contudo, já se demonstrou que o magistrado tem sim interesses de caráter público, ou seja, deseja que o instrumento processual seja o mais efetivo possível; que dele se possam extrair os melhores resultados, atingindo com isso a concretização da norma material e a pacificação social.

Assim, as ações do juiz devem ser direcionadas à busca da tutela jurisdicional justa, e não no sentido de beneficiar alguém. O que aqui se afirma é que o ativismo do juiz é em busca da consecução de um interesse público, que nada tem a ver com o interesse privado das partes. Dessa forma, sua movimentação não beneficiará um ou outro, mas sim favorecerá o encontro da verdade dos fatos e das intenções estatais processuais.

Partindo dessa linha de pensamento, tendo sido demonstrado que juiz ativo não significa necessariamente juiz favorecedor de um ou de outro litigante, não há como concluir que o aumento dos poderes do juiz ferirá obrigatoriamente a igualdade entre as partes. $^{394}$

Ao contrário. Um juiz que esteja diante de um cenário incompleto dos acontecimentos e refute uma alteração que apresente relevo à definição e veracidade da cries, ignorando a possibilidade de uma justa decisão, nada mais é que um magistrado anuente com um resultado tendencioso e descolado da realidade. Portanto, ao contrário do

\footnotetext{
393 "Certamente, questa <neutralità> non sarebbe sostenible, ove determinasse l'aspirazione ad un'<apolicità> dell'organo di giurisdizione costituzionale. Se la decisione delle controversie costituzionali impone una <scelta giudiziale $>$ fra interessi sociali in contrato, ad essa è razionalmente collegata una <social preferece>, la quale deve come tale emergere con chiarezza dal contesto della decisione. Con altrettanta evidenza deve trasparire dalla motivazione l'eventuale incindenza Che la previsione delle ripercussioni sociali o politiche del risultato da raggiungere abbia avuto sul contenuto della decisione medesima" Cf. LUIGI Paolo Comoglio, La Garanzia Constituzionale della Azione ed il Processo Civile, Padova, 1970, p. 27.

${ }^{394}$ Em sentido contrário, AROCA, El proceso civil llamado 'social', cit. pp. 150 e ss.
} 
argumento da imparcialidade, são exatamente nessas situações que se tem um juiz parcial e favorável à desigualdade entre os litigantes.

Ademais, em casos em que haja um juiz que vise ao favorecimento privado de um dos litigantes, o interessante é que o conjunto representativo seja nebuloso, subjetivo e com limites distorcidos. Julgar com parcialidade um conflito objetivamente representado, completo, comprovadamente verídico e que teve seus resultados advindos de um procedimento legítimo exporia com grande facilidade as máculas de sua decisão. Logo, também por esse perfil, não se sustenta o argumento que equipara um juiz ativo a juiz imparcial.

Feitas essas ressalvas, voltando ao núcleo do tema, é de se destacar que a atividade do juiz destinada a reconstruir a verdade e completude dos fatos não é ilimitada. $\mathrm{O}$ ordenamento positivo, conforme já dito alhures, impõe ao magistrado a vedação do uso do conhecimento privado (art. 128, CPC). Ele somente poderá fazer juízo sobre os enunciados fáticos e jurídicos aportados ao processo, quer pelas partes, quer por terceiros.

Entretanto, se analisado o conjunto representativo por uma ótica gnosiológica e lingüístico-psicológica, vê-se que a atividade de construção de enunciados de fato e de direito são elementos lingüísticos. Como se disse anteriormente, várias são as formas de narração de um evento, todas elas condizentes com a realidade e aptas a representar parcialmente o fenômeno concreto. Assim, o juiz estaria autorizado a formular novos enunciados sobre os fatos aportados aos autos. Em outras palavras, não obstante a vedação de aporte ex offcio, poderá o juiz redefinir a perspectiva e construir semântica, seletiva, categorial e culturalmente narrações sobre objetos já contidos no âmbito do processo.

Assim, juiz e partes, ao atuar a possibilidade de modificações dentro do cenário traçado, contribuem para a formação de um conjunto enunciativo mais real e completo, aumentando a possibilidade de uma decisão mais justa.

\subsubsection{A modificação da demanda e a correta aplicação da lei}

O presente tópico do trabalho se destina a analisar a relação entre o instituto modificativo e a formação da premissa maior por parte do julgador, buscando demonstrar como ele pode favorecer a correta aplicação da lei ao caso concreto. 
Conforme foi dito várias vezes ao longo do trabalho, infinitas são as possibilidades de formulação de enunciados fáticos sobre um mesmo evento. Os enunciados colocados à base do ato introdutório são frutos de vários processos construtivos, podendo-se citar, por exemplo, o seletivo, o semântico, o categorial e o cultural. ${ }^{395}$

Os próprios fatos a serem narrados também são meticulosamente selecionados pelos defensores das partes, sendo estruturados dentro do ato com graus de importância variados. O critério usado para 'peneirar' os acontecimentos reais é justamente a lei por eles escolhidas. É ela que irá definir o que é relevante e o que é secundário, e até mesmo o que é irrelevante dentro da estrutura das manifestações. ${ }^{396}$

Desse modo, o fato não é dado autonomamente; as normas formam uma grelha de filtro. É o direito que define e determina a porção do conflito real que será destinado a construir a controvérsia jurídica sobre a qual verterá a demanda. ${ }^{397}$

Ocorre, porém, que se é verdade que as proposições normativas, além de uma parte que exprime o conteúdo preceptivo, contêm uma fração que descreve e individua o 'tipo' dos fatos relevantes (prótase factual), aos quais coliga uma consequiência jurídica, não é tão verdade assim que os modos com os quais as normas se ocupam desses fatos sejam únicos e incontroversos, tampouco se podendo dizer que a maneira como elas atribuem relevância aos eventos concretos da vida seja algo pacífico e inconteste.

Ao contrário, a escolha de quais fatos jurídicos serão objeto da decisão constitui um processo complexo de interpretação por parte de quem julga. O juiz é chamado a afrontar uma complexa operação de construção da premissa maior, processo interpretativo esse que consiste na individuação do significado da parte da norma relativa aos fatos e na conseqüente seleção dos acontecimentos que estarão à base da decisão. ${ }^{398}$

A norma, portanto, configura uma estrutura semântica aberta, apresentando antes do juízo um estágio incompleto e provisório. Os fatos, hipotética e provisoriamente, guiam

\footnotetext{
${ }^{395}$ Para aprofundamentos, vide item 2.4 , retro.

${ }^{396}$ WRÓBLEWSKI, Legal language and legal interpretation, cit. pp. 131 e ss.; CSABA VARGAS, The mental transformation of facts into a case, in ARSP, 1991, pp. 58 e ss.

${ }^{397}$ CSABA VARGAS, The mental transformation, cit. pp. 61 e ss.; GAMBA, Domande, cit. p. 189.

${ }^{398}$ ESSER, Precomprensione e scelta del método nel processo, cit., p. 112; TARUFFO, Sulla complessità della decisione giudiziaria, in Psicologia culturale, 2013, n. 3, p. 33 e ss; WRÓBLEWSKI, Ideologia de la aplicación judicial del derecho, Géssie Fontus (trad.), Instituto de investigaciones jurídicas de la Unam, 1992, pp. 19 e ss.
} 
o juiz na individuação do preceito normativo dentre todos aqueles possivelmente aplicáveis ao caso concreto, tudo conforme foi explanado no capítulo precedente quando se tratou da teoria dos círculos hermenêuticos de interpretação.

As propostas normativas feitas pelas partes, porém, são meramente sugestivas e portadoras de informações quanto à crise. Servem, em última análise, para que o juiz possa analisar em que sentido o bem da vida é buscado pelo autor em termos legais.

Contudo, tal formulação, como já dito, não vincula o magistrado, que pelo principio do iura novit curia poderá alterar os fundamentos de direito sem que como isso desnature as pretensões do autor. ${ }^{399}$

A modificação de enunciados de direito, tal como ocorre com as alterações fáticas e aqui aceitas de forma menos resistente pela doutrina ${ }^{400}{ }_{-}$, serviriam como novos elementos informativos aptos a melhorar a demanda ao longo da dinâmica processual, dando apontamentos auxiliares no momento da formação do juízo de direito. ${ }^{401}$

Feita uma breve análise de como a modificação poderia colaborar com cada um dos requisitos de atribuição de justiça à decisão, cabe nesse momento demonstrar quais seriam os limites do ius variandi. É o que se passa a fazer.

\subsection{Instituto modificativo e seus limites na visão proposta}

Pensar em limites para o instituto modificativo implica, necessariamente, analisar o problema por duas perspectivas: a de seu conteúdo e a de seu momento.

A modificação da demanda, conforme se estruturou acima, é o instituto processual pelo qual se pode atribuir melhorias à formatação da demanda, suprindo falhas e corrigindo distorções, para dar um grau superior de qualidade à sentença. No que tange às partes, tais podem trazer aos autos os fatos que bem entenderem, mas a entrada do enunciado novo no

\footnotetext{
${ }^{399}$ Nesse sentido: STJ, AgRg no REsp 1455713, Segunda Turma Julgadora, Rel. Min. Mauro Campbell Marques, j. 18.11.2014; STJ, REsp 1197476, Terceira Turma Julgadora, Rel. Min. Ricardo Villas Bôas Cueva, j. 10.10.2014.

${ }^{400}$ Dentro da visão clássica, ver: ORMAZABAL SÁNCHEZ, Iura novit curia, Barcelona-Madrid, 2007, pp. 58 e ss.; Micheli, Jura novit curia, Riv. dir. proc., 1961, pp. 575 e ss.; SENTís MELENDO, El juez y el derecho (Iura novit curia), Buenos Aires, 1957, pp. 9 e ss.

${ }^{401}$ Para a jurisprudência, o princípio aludido não fere os limites impostos pela lei: STF, AI 794759 AgR/SC, Primeira Turma Julgadora, Rel. Min. Luiz Fux, j. 13.04.2011;
} 
conjunto de asserções objeto do juízo de fato somente será permitida com a autorização do juiz. As modificações de direito seguem a mesma regra, devendo-se, por óbvio, observar a estrutura jurídica que dá suporte ao pedido de tutela jurisdicional. Em outros termos, caso se altere a roupagem dos fatos a ponto de alterar a natureza da crise (de certeza passa-se a inadimplemento; de inadimplemento passa-se a efetivação de um direito potestativo, dentre outras), o pedido deverá ser também alterado, uma vez que "da narração dos fatos" deve “decorrer logicamente a conclusão" (art. 295, CPC).

Os pedidos, igualmente, deverão ser alterados passando-se pelo crivo do juiz. Em regra, é possível pensar em um sistema que autorize qualquer tipo de modificação, relacionadas ou não com os limites iniciais propostos. Contudo, é de se imaginar que ao menos os novos pedidos tenham que ter vínculos com a estrutura inicialmente exposta. Caso contrário, haveria adição de elementos externos e alheios à crise que somente viriam a trazer aos autos contra produtividade. O magistrado, ao autorizar a ampliação de requisições, deve ter em mente os requisitos de veracidade e completude da crise que balizam a decisão justa.

A subtração de pedidos, todavia, é algo bastante interessante e curioso. Se o instituto modificativo serve para buscar uma aproximação dos limites representativos aos reais contornos da crise, uma eventual desistência de tutela parece andar na contra-mão do que fora proposto. Não obstante isso, parece, pelo menos para quem escreve, que vedar essa atividade de redução vai de encontro com a dispositividade dos direitos no plano material. Desse modo, encara-se como bastante satisfatória a sistemática adotada pelo atual Código de Processo Civil, que dispõe que "o autor não poderá, sem o consentimento do

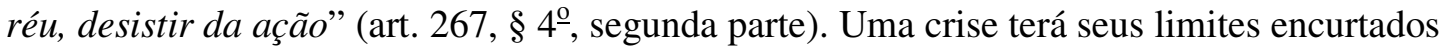
somente - e tão somente - se as partes, pautando-se pela dispositividade do direito, estiverem de acordo.

Os limites para se reduzir a crise exposta, pois, é a aquiescência da contra parte.

No que tange aos fatos, porém, a subtração enunciativa parece algo incompatível. Conforme já dito, ninguém dispõe dos acontecimentos da vida. Eles simplesmente acontecem, não sendo lógico pensar que a parte pode dele dispor (pelo menos se encarado o problema pela acepção técnica do termo ‘disposição'). O que pode acontecer é a omissão narrativa por parte de um dos envolvidos quanto a um determinado evento, o que, como já 
referido, faria o juiz não poder se manifestar sobre ele de ofício, salvo se referente às exceções previstas em lei. ${ }^{402}$

Porém, uma vez enunciado no processo, o fato passa a fazer parte do conjunto informativo destinado ao julgador. Retirar o conteúdo de dados já inseridos na consciência do juiz, ainda que os enunciados possuam inicialmente caráter hipotético e apofântico, além de apresentarem grau cognitivo zero, parece ser algo logicamente impossível. Uma vez no cenário processual, poderá o juiz livremente se manifestar sobre ele como bem entender.

No que se refere ao julgador, inclusive, considerando a função aqui proposta para o instituto e as vedações legais ao uso do conhecimento privado, os limites para a atividade modificativa toma os seguintes contornos: 1) sabendo que a modificação dos enunciados pode consistir na variação e no complemento das hipóteses de fato inicialmente postas à base da decisão, os acontecimentos poderão ser reconstruídos em uma versão diferente daquelas propostas inicialmente pelas partes, fazendo vir a lume perfis deixados de lado estrategicamente pelo narrador originário; 2) demandas fundadas em fatos complexos devem ser abertas a ponto de a modificação poder trazer circunstâncias simples que inicialmente não foram objeto de expressa descrição operada pelos envolvidos, mas narradas de um modo ou de outro pelos demais agentes do processo (testemunha, peritos, membros do ministério público, terceiros etc.). No momento no qual as partes colocam situações complexas como foco de suas hipóteses fáticas, toda categoria dos eventos submetidos àquela situação devem ser considerados objeto de alegações implícitas ${ }^{403}$; e 3) o juiz estará livre para reenquadrar juridicamente os fatos, bem como para alterar seus graus de relevância dentro do processo, mantendo-se, porém, os efeitos requeridos pelo autor na inicial (condenação, declaração e constituição).

Em relação ao momento em que se deve bloquear a atividade modificativa, é possível pensar que a atividade enunciativa novatória pudesse ser livre de preclusões até o trânsito em julgado, abrangendo, em última análise, uma liberdade, inclusive, na fase de recursos e Tribunais Superiores.

402 Sobre as questões releváveis de ofício em grau de recursos, além da literatura já apontada, ver: CAVALlini, L'eccezione 'nuova' rilevabile d'ufficio nel giudizio d'appello riformativo, in Riv. dri. proc., 2014, n. 3, pp. 588 e ss.

${ }^{403}$ GAMBA, Domande, cit. p. 237. As mesmas considerações servem para o background fático das narrativas das partes, quer sobre fatos simples, quer fatos complexos. Sobre o substrato dos acontecimentos, TARUFFO, La prueba de los hechos, pp. 126-127. 
Ocorre, porém, que tais situações não são compatíveis com o sistema positivo brasileiro material. Os tribunais de sobreposição, independentemente do debate quanto aos limites de poder na avaliação de fatos e direitos ${ }^{404}$, não possuem, salvo em alguns poucos casos previstos em lei, cognição exauriente. Nesse sentido, qualquer proposta de alteração dos limites do instituto modificativo nesse sentido requereria, antes de tudo, mudanças constitucionais das funções desses tribunais. Ademais, tais quais os tribunais de segunda instância, por suas próprias estruturas, possuem condições limitadas de produção de provas, fato que dificulta o aporte de inputs para a alteração do estado cognitivo zero relativo a novos enunciados formulados em sede de recursos. Justamente por essa limitação, acredita-se que a estrutura dada pelo art. 517 do CPC atual é mais do que suficiente para tratar a contento das questões residuais das formulações de novas questões de fato e de direito em sede de apelação (ou qualquer outra via recursal).

A ampliação dos pedidos nessas sedes, por seu turno, esbarraria em regras relativas ao duplo grau jurisdição. ${ }^{405}$

Por essas singelas observações, acredita-se que os limites temporais ideiais para o exercício da modificação dos enunciados e dos pedidos, levando-se em consideração tudo o que fora dito até aqui, seja a sentença de primeiro grau, momento no qual o procedimento construtivo das premissas de fato e de direito serão finalizadas e a decisão do caso será evidenciada pelo julgador.

Dito isso, e para finalizar, importante rebater, ainda que de forma superficial, alguns dos argumentos contrários à sistemática de livre alteração dos enunciados e dos pedidos ao longo do procedimento cognitivo em primeiro grau, de resto, contrários à própria proposição ora exposta.

\subsection{Insubsistência das críticas ao modelo de liberdade modificativa}

\footnotetext{
${ }^{404}$ Para aprofundamentos sobre o tema, na doutrina nacional KINIJNIK, O recurso especial e a revisão de fato pelo superior tribunal de justiça, Rio de Janeiro, 2005, pp. 83 e ss.; em âmbito acadêmico, RECENA COSTA, Superior Tribunal de Justiça e recurso especial: análise da função e reconstrução dogmática, 2011, em dissertação de mestrado em direito, Faculdade de Direito da Universidade de São Paulo, pp. 98 e ss; na doutrina internacional, por todos, TARUFFO, Il vertice ambíguo. Saggi sulla cassazione civile, Bologna, 1991, pp. 117 e ss.

${ }^{405}$ Para o tema do jus novorum pela perspectiva clássica em grau de apelação, STEFANIA MAGNONE, Sui limiti temporali della proponibilità di eccezioni nuove in appello, in Riv. dir. proc., 1978, pp. 119 e ss.; pela perspectiva dinâmica, MONTESANO, Invocazione per la prima volta in appello dell'usucapione, cit., pp. $112 \mathrm{e}$ ss.
} 
Em geral, duas são as críticas dirigidas ao modelo de liberdade modificativa. A primeira delas é relativa aos possíveis retrocessos que uma alteração de fato e de direito poderia causar na marcha do processo ${ }^{406}$. O litigante que sabe não ter razão, em tese, seria particularmente beneficiado, pois, direcionado por uma má-fé, usaria seus direitos para procrastinar ao máximo o feito e impedir que uma decisão fosse emitida com celeridade, retardando-se assim a solução da crise.

Tais observações e preocupações da doutrina não são privadas de razão. As partes, como tantas vezes se disse aqui, são movidas dentro do processo pelos seus interesses privados. Qualquer possibilidade de previsão de perda seria, sem sombra de dúvida, um estímulo para o retardamento do feito por meio da modificação.

Entretanto, tal problema pode ser resolvido com a imposição de um limite específico à entrada da modificação no âmbito processual, qual seja: a autorização do juiz. Sendo ele quem deve realizar o juízo de fato e de direito, somente ele poderá avaliar se as alterações narrativas serão ou não serão úteis; se são ou não compatíveis com os objetivos de completude e realidade da representação. Nos casos em que constatar uma má-fé da parte no uso de sua faculdade, poderá condená-la por litigância nos termos dos dispositivos do CPC.

Outro ponto bastante citado é que a modificação livre e irrestrita das matérias de ataque e de defesa proporcionaria aos litigantes uma estratégia de surpresa: eles guardariam para o fim, em busca de surpreender seu adversário, os fatos e consequiências jurídicas mais importantes, transformando o processo em um meio permeado pela chicana, pela surpresa, pelo favorecimento dos mais fortes e espertos etc.

Não obstante a freqüência com que esse argumento é levantado, acredita-se que ele é mais figurativo que realmente efetivo. Em um cenário regulado pelo juiz, no qual todas as modificações devem passar pela aprovação do magistrado, é muito improvável que os advogados colocassem todo o êxito processual em risco apenas e tão somente para

\footnotetext{
${ }^{406}$ Ambas podem ser vistas nas emendas feitas ao anteprojeto do senado para o novo CPC. Não obstante o fato de o tema ter sede própria nesse trabalho, cita-se, a título de adiantamento, o parecer do Instituto dos Advogados Brasileiros, IAB, que sugeria a supressão do então art. 314, que estipulava um sistema modificativo aberto, sob o pretexto de que "tal dispositivo vai de encontro ao ideal de celeridade que norteia todo o Projeto, ao permitir que, após a estabilização da lide, o autor altere seu pedido e a causa de pedir, ainda que não venha a causar prejuízo ao réu”., acessado em 01.12.2014, em http://www.iabnacional.org.br/IMG/pdf/doc-3241.pdf.
} 
surpreender a parte contrária. Em outras palavras, esconder um fato importante para a tese estruturada pode ser fatal caso o juiz não autorize que suas enunciações ulteriores sejam aportadas ao processo. Não há qualquer razão racional para pensar que, mesmo correndo esse risco, os patronos das partes utilizariam um estratagema inovatório desse tipo.

Colocar à disposição da sorte um fator importante como esse somente por acreditar que a surpresa o irá fazer ganhar o caso, em realidade, parece mais um contra-senso lógico que realmente um argumento que consiga obstar uma busca por sistematizações melhores do instituto modificativo.

Que as facetas patológicas do instituto devem ser levadas em conta, isso não há dúvida. Contudo, colocá-las como ponto principal e apoiar-se nelas para refutar uma construção de contornos novos parece um equívoco inaceitável.

A função de atribuição de qualidade à decisão, considerando todas as faces de parcialidade, incompletude, de subjetivismo e potencialidade em serem falsas, características epistemológicas das asserções de fato e de direito normalmente deixadas de lado pela doutrina tradicional, parece ser o caminho para diminuir as distorções do conjunto representativo inicial.

Os benefícios do sistema proposto, ao menos aos olhos de quem escreve, parecem ser muito maiores que as pequenas distorções geralmente apontadas e tidas como questões centrais para o desenvolvimento do tema.

Aproximar o conjunto representativo da realidade, evitando-se o fenômeno da indiferença da decisão e fazendo com que a resposta seja a mais correta possível para a pergunta dos jurisdicionados, parece ser argumento suficiente para se flexibilizar o sistema de preclusões. Isso, evidentemente, se o que se busca é a efetividade do processo e a pacificação social com justiça. 


\section{A MODIFICAÇÃO DA DEMANDA NO ORDENAMENTO POSTO}

O presente capítulo da dissertação tem como objetivo analisar como o sistema positivo dispôs, dispõe e disporá - quer no procedimento comum, quer nas ações coletivassobre o instituto modificativo. Buscar-se-á por meio de uma visão crítica apontar vantagens e desvantagens das variadas sistemáticas dos códigos e leis em comparação com a estrutura proposta, sempre levando em consideração a visão epistemológica das narrações das partes e o escopo instrumentalista da modificação da demanda (tomada, como é óbvio, na acepção trazida no capítulo anterior) em busca de uma decisão justa, efetiva e condizente com os limites reais da crise.

\section{1 - O procedimento comum}

\subsubsection{O procedimento comum no Código de 1939}

Para começar o estudo do direito positivo, tomam-se como ponto de partida as disposições legais contidas no Código de Processo Civil de $1939 .{ }^{407}$

O citado diploma legal tratava em seu art. 158 que a ação teria início "por petição escrita, na qual, delimitados os termos do seu objeto" deveriam ser indicados: "III - o fato e os fundamentos jurídicos do pedido, expostos com clareza e precisão, de maneira que o réu possa preparar a defesa" e "IV-o pedido, com as suas especificações".

A matéria legal, anteriormente ao citado artigo, previa que, em caso de omissão na inicial por parte do autor de pedidos que lhe eram lícitos fazer, somente poderia formulálos em uma nova ação (art. 157). Em outros termos, não requerida uma determinada tutela no ato introdutório, o interessado poderia tão só requerê-la em demanda autônoma.

Combinando-se aquela redação com a do art. 181, que dispunha que depois da citação estava vedado qualquer tipo de aditamento ao pedido e à causa de pedir, pode-se

${ }^{407}$ Para análise perfunctória do direito Hispano-Lusitano, com reflexos no ordenamento pátrio anterior, ver a já citada obra de TUCCI, A causa de pedir, pp. 63-73, especificamente sobre os Códigos estaduais, p. 143. 
perceber que a preclusão quanto aos ditos elementos objetivos era imposta ao autor já nas suas primeiras manifestações no processo. ${ }^{408}$

Em relação ao réu, o Código nada dispunha quanto a exigências de apresentação de toda a matéria de defesa já com a contestação. Tampouco, como aponta a doutrina, fazia menção ao ônus de impugnação específica ${ }^{409}$. Entretanto, conforme se posicionaram alguns estudiosos, o princípio da eventualidade poderia ser extraído do conjunto de artigos que regulamentava a matéria. ${ }^{410}$

Os processualistas, permeados pela visão clássica da identificação da demanda, pareciam ter como algo assente que o CPC de 39 havia adotado a teoria da substanciação ao exigir do autor uma exposição clara e precisa dos fatos e dos fundamentos jurídicos ${ }^{411}$. Chegou-se a afirmar que até mesmo as ações que versassem sobre direitos reais deveriam trazer com a exposição fática o título aquisitivo da propriedade. ${ }^{412}$

No que tange ao objeto do trabalho, buscavam os pensadores em seus estudos verificar, dentro dos padrões tradicionais, quais os limites de alteração dos fatos e dos fundamentos jurídicos que não implicariam em mutatio libelli.

Por essa ótica, tendo em vista uma pretensa adoção da teoria da substanciação em grau bastante intenso, a margem para modificações dos enunciados era muito limitada. Adicionar ou substituir o pedido era expressamente vedado, como se viu acima. Os fatos, no mesmo sentido, eram gradativamente cristalizados em seus moldes iniciais com a contestação e, subseqüente e definitivamente, com o despacho saneador.

Desse modo, as deficiências representativas das narrações das partes se mantinham ao longo de todo o arco procedimental. Eventuais necessidades de 'ajustamentos do tiro'

\footnotetext{
${ }^{408}$ Galeno LaCERDA, Despacho saneador, Porto Alegre, 1953, p. 178.

${ }^{409}$ SiCA, Preclusão, cit. p. 48.

${ }^{410}$ Celso AgRícola BARBi, Da preclusão no processo civil, in Revista Forense, n. 158, 1955, pp. 61 e ss.

${ }^{411}$ Nesse sentido, apenas como referências exemplificativas, PONTES DE MIRANDA, Comentários ao Código de Processo Civil, tomo II, Rio de Janeiro, 1947, pp. 28 e ss; CALMON DE PASsos, Causa de pedir, in Enciclopédia Saraiva do Direito, v. XIV, São Paulo, 1983, pp. 50 e ss.. Destoando da maioria, alegando que o código adotou teoria intermediária, BOTELHO DE MESQUITA, A causa petendi nas ações reivindicatórias, cit. 179. Com ampla bibliografia sobre o período e as várias opiniões, TUCCI, A causa de pedir, cit. pp. 144 e ss.

412 TUCCI, ibidem, p. 146. Quanto às críticas que se podem fazer referente a essa perspectiva de análise, em específico à bifurcação conceitual da heterodeterminação e autoderterminação, vide supra, item 1.4. Demandas heterodeterminadas $x$ autodeterminadas e a modificação.
} 
eram duramente rechaçadas. A demanda, nos moldes em que proposta, permanecia independentemente da qualidade que fora formulada.

O sistema pré CPC de 1973 era, como se nota, bastante rígido, com preclusões bastante intensas, o que dificultava em certos casos a modificação dos enunciados a título de atribuição de correção da demanda e, como conseqüência, de qualidade à decisão.

O plano de fundo era preterido em favor das formas.

\subsubsection{O procedimento do Código de 1973}

A matéria da modificação da demanda, em relação ao Código de 1939, sofreu poucas alterações com a entrada em vigor do diploma de 1973. Tal legislação previu de maneira muito semelhante o conteúdo do ato introdutório. Em seu artigo 282, incisos III e IV, dispôs que a petição inicial deverá indicar 'o fato e os fundamentos jurídicos do pedido', além, é claro, do próprio pedido ‘com as suas especificações'. Houve, conforme juízo comparativo, a supressão da expressão "expostos com clareza e precisão" relativa aos fatos postos à base da demanda.

A retirada dos termos acima fez com que alguns doutrinadores, referindo-se ao Código atual, se posicionassem no sentido de que o legislador processual teria mitigado a teoria da substanciação ao exigir que o autor expusesse em sua demanda os fundamentos jurídicos, que nada mais seria que a individuação do direito feito valer. Desse modo, teria o CPC de 1973 adotado uma teoria intermediária de identificação da causa petendi. ${ }^{413}$

Pela perspectiva da identificação da ação, a teoria da substanciação mitigada pela supressão frasal - ou, como preferem alguns, a adoção de uma teoria intermediária entre substanciação e individuação - poderia soar como uma pequena abertura para a modificação dos fatos no desenvolvimento do processo.

\footnotetext{
413 Milton Paulo de Carvalho, Do pedido no processo civil, Porto Alegre, 1992, pp. 92-93, assim se manifesta: "Temos para nós que o conteúdo da causa de pedir, derivado da aplicação dos preceitos legais inicialmente transcritos, foi-se definindo, no direito brasileiro, com os contributos das teorias da substanciação e da individuação, à margem da própria letra da lei (haja vista a conclusão de Mesquita com apoio no art. 158, III, do Código de 39), no sentido de ser apurada a chamada causa próxima, ou fundamento jurídico, da conjugação da descrição do fato (causa remota) com a pretensão formulada".
} 
As ações autodeterminadas, por exemplo, não mais dependeriam da apresentação do título aquisitivo da propriedade, tal como defendiam no âmbito do Código anterior. Os fatos constitutivos do direito real poderiam, assim, serem alterados livremente. No caso das heterodeterminadas, bastava que a relação jurídica fosse individualizada com clareza.

Todavia, conforme mostrado no item 1.4 e 1.5, as tais bifurcações teóricas não possuem a menor razão de ser, interpretando o problema, segundo a visão aqui adotada, de maneira equivocada.

Ao considerar as características reais dos atos narrativos introdutórios e interpretar os limites da modificação da demanda como algo relativo às preclusões, conclui-se que ambos os sistemas são muito parecidos.

É de se destacar que o art. 264 do CPC, uma das principais referências legais responsáveis por regular a matéria, dispõe que, "feita a citação, é defeso ao autor modificar o pedido ou a causa de pedir, sem o consentimento do réu, mantendo-se as mesmas partes, salvo as substituições permitidas por lei", fechando a sistemática preclusiva, em seu parágrafo único, nos seguintes termos: "a alteração do pedido ou da causa de pedir em nenhuma hipótese será permitida após o saneamento do processo".

Como se nota, o legislador processual, naquilo que concerne à alteração dos enunciados de fato e de direito, bem como aos pedidos, impôs ao autor dois momentos preclusivos ${ }^{414}$, qual seja: a citação do réu e o saneamento do processo. Antes do primeiro, poderá o demandante alterar seus enunciados como bem lhe aprouver; depois da citação até o despacho saneador, somente com a concordância do seu adversário; ultrapassado esse momento, perde por completo possibilidade de realizar a atividade processual modificativa.

Em suma, a mesma estrutura do Código anterior.

Os limites temporais, desse modo, são bastante claros. Poder-se-ia alegar, porém, que a diferença entre um diploma e outro estaria a cargo do conteúdo das vedações.

Como se viu, os conceitos de causa de pedir e pedido, entendidos em ambos os momentos como grandes simplificações, interpretados como elementos definidos já no momento em que são trazidos aos autos pelas partes, possuem um caráter absoluto e rígido, independentemente do regramento em que inseridos (o problema, pois, é de perspectiva)

${ }^{414}$ Momento preclusivo é usado no texto de forma elíptica. 
Para os adeptos da metodologia identificativa, seria necessário individualizar o que comporia a causa de pedir e o pedido do autor para, só depois, verificar se algo pode ou não entrar no processo depois dos limites procedimentais da lei.

Ocorre, todavia, que como causa de pedir e pedidos não são instituições abstratas capazes de englobar todas as situações narratológicas da vida, identificá-los precisamente na prática, conforme se tentou demonstrar até então, é uma tarefa difícil, senão impossível. Assim, as aproximações forçadas feitas entre o plano teórico e o plano prático acabam por gerar uma imensa insegurança jurídica quanto aos limites permitidos para as alterações, tanto no diploma processual atual quanto no anterior (de resto, como se pôde ver no capítulo primeiro do presente trabalho, em toda a doutrina que assim encara o tema). ${ }^{415}$

Nesse regimento, a demanda, até o despacho saneador, pode ter seus limites reajustados em busca de um melhor cenário representativo, mas tal aperfeiçoamento está condicionado ao consenso entre as $\operatorname{partes}^{416}$, o que, segundo a experiência prática, quase nunca acontece.

Entretanto, tentando extrair do sistema posto uma capacidade maior de atribuição de qualidade à demanda, busca-se outra maneira de encarar o sistema preclusivo positivo. Tal forma é tomando os conceitos de causa de pedir e pedidos pela perspectiva epistemológica proposta, na qual não são mais que enunciados meramente portadores de informações (parciais e incompletas) quanto aos limites da crise. Assim encarado o problema, a abertura para modificações se ampliaria para fora dos limites processuais, abarcando elementos da crise e dos fenômenos que não entraram no processo, aproximando-se, com isso, ainda que em termos restritos, os reais limites da crise ao cenário representativo das manifestações.

A preclusão, pois, faria com que as partes perdessem a possibilidade de portar aos autos enunciados referentes a eventos inéditos, mas não bloquearia a possibilidade de

\footnotetext{
${ }^{415}$ A simplificação que tanto se combate, por exemplo, não leva em consideração as construções parciais das partes. Nesse sentido, ignora o fato de que um mesmo fato poderá ser narrado de infinitas maneiras verdadeiras. Ignora, outrossim, a questão da decomposição qualitativa e quantitativa do evento. Logo, a teorização entre em crise quando se traz ao processo elementos do mesmo acontecimento, mas narrado de uma outra perspectiva. Poderá ou não o juiz aceitar a modificação do enunciado? Essa é uma questão fundamental para a resolução prática dos problemas vinculados ao tema, mas que a doutrina tradicional não consegue responder satisfatoriamente.

${ }^{416}$ Moniz de Aragão, Comentários ao Código de Processo Civil, v. II, Rio de Janeiro, 1983, p. 456
} 
alterarem as perspectivas narratológicas sobre os fatos já contidos no conjunto narrativo ${ }^{417}$. O mesmo evento da vida poderia ser objeto de análise por vários outros pontos de vista (rototranslação narratológica), assim como poderia ser recomposto tanto quantitativa como qualitativamente. O juiz, por seu turno, também poderia reformular enunciados, bem como considerar eventos que estão à base dos fatos narrados (o chamado background fático). ${ }^{418}$

Ocorre, porém, que tal sistemática, pelo menos aos fins pretendidos pelo trabalho, não satisfaz por completo. Embora a visão epistemológica tenha traços de evolução em comparação à doutrina clássica, a perda da possibilidade de aporte de eventos inéditos, muitas vezes desconhecidos pelas partes, pode gerar um descolamento entre a base representativa da demanda e os reais limites da insatisfação, comprometendo a justiça da decisão. A vedação ao aporte de novos conteúdos de informação - ou a substituição daqueles já existentes por outros - pode ser fundamental para a configuração do que se chamou de "indiferença da decisão" resposta, inaceitável para uma visão processual moderna pautada pelo instrumentalismo.

Logo, conforme visto no capítulo precedente, o bloqueio do conteúdo informativo nos limites das manifestações iniciais das partes não é, tal qual faz o CPC de 1973, o momento ideal para que a preclusão incida.

\subsubsection{O procedimento comum do Anteprojeto}

Falar de projeto de novo Código de Processo Civil, como se homogêneo fosse o conteúdo da expressão, é algo inviável. Muitas foram as emendas propostas ao texto original do Senado, sendo uma tarefa hercúlea (e pouco produtiva, frise-se) compilar e reproduzir todas elas nessa seara. Por essa razão, crendo ser suficiente o cotejo entre a redação originária do PLS n. 166/2010 e a redação final da Câmara dos Deputados para

\footnotetext{
417 Uma das conseqüências práticas desse enclausuramento é o que a doutrina chama de princípio da eventualidade, pelo qual autor e réu devem oferecer toda matéria de ataque e de defesa em suas manifestações iniciais, inclusive se contraditórias entre si. Para uma análise do perfil histórico e comparativo desse princípio, Everaldo DE SouZA, Do princípio da eventualidade no sistema do Código de Processo Civil, in Revista Forense, n. 251, 1975, pp. 101 e ss.

${ }^{418}$ Para maiores aprofundamentos, vide item 2.4.1.2. O fato e sua complexidade, retro.

${ }^{419}$ ENRIQUes, Do Corporate Law Judges Matter?, cit., pp. 765 e ss; Id., Il nuovo diritto societario nelle mani dei giudici: una ricognizione empirica, in Stato e mercato, 2001, I, pp. 79 e ss.
} 
aferir o que permeou todo o debate entre legisladores e entre doutrinadores, tomar-se-ão como objeto de estudo dois artigos em específico: o 314 do anteprojeto original e o 330 da redação final.

$\mathrm{O}$ art. 314 do anteprojeto do Senado previa que o autor poderia, enquanto não proferida a sentença, aditar ou alterar o pedido e a causa de pedir, desde que o fizesse de boa-fé e que não importasse em prejuízo ao réu, sendo assegurado o contraditório mediante a possibilidade de manifestação deste no prazo mínimo de quinze dias, sendo facultada a produção de prova suplementar, previsões esses extensíveis, segundo o parágrafo único, ao pedido contraposto do réu e a sua respectiva causa de pedir.

Como se nota, os legisladores processuais haviam previsto um sistema preclusivo aberto, pelo menos no que concernia ao primeiro grau de jurisdição. $\mathrm{O}$ autor, bem como o réu, poderiam livremente modificar suas enunciações de fato, de direito, bem como os seus pedidos até o momento anterior à prolação da sentença. Os únicos requisitos para a atividade modificativa ficavam a cargo de elementos externos ao processo, isto é, a boa-fé do agente e o não prejuízo à parte contrária.

Ao que se dessume da leitura do dispositivo legal apontado, as alterações feitas pelas partes em suas narrações não dependeriam de qualquer autorização feita pelo magistrado, destinatário final dos enunciados hipotéticos. Não havendo má-fé e nem danos, a modificação deveria ser incorporada ao conjunto representativo inicialmente construído pelos indivíduos.

Tal artigo foi intensamente combatido pelos operadores do direito. Em parecer formulado pelos membros do Instituto dos Advogados Brasileiros - o IAB, confeccionado no ano de 2010, mesmo ano de formulação do anteprojeto, sugeriu-se a supressão de tal dispositivo da redação original, tudo por entender que ele iria de encontro ao ideal de celeridade que permeava todo o diploma.

Em certa medida, os críticos poderiam ter razão. Conforme exposto acima, o cenário modificativo deve estar sujeito a um controle por parte do juiz. Se o instituto modificativo visa ao aperfeiçoamento da demanda, trazendo seus limites representativos o mais próximo possível dos contornos da realidade da crise, e as novas enunciações possuem as mesmas características de parcialidade, potencial falsidade, incompletude e subjetividade das asserções iniciais, então para que se possível atingir o escopo é necessário um controle externo. 
A redação, da maneira como foi feita, dá a entender que o aditamento ou modificação dos pedidos e da causa de pedir devem, obrigatoriamente, entrarem no processo. Se isso for de fato verdade, a possibilidade de atrasos e contramarchas do procedimento é enorme, dando azo àquele que não tem razão para usar de suas faculdades modificativas com má-fé.

Contudo, segundo a visão adotada pelo presente trabalho, o dispositivo em comento apresentava evoluções estruturais significativas. Impunha como limite à atividade modificativa a decisão em primeiro grau. O correto, segundo a estrutura aqui sugerida, seria tão só acrescentar o controle judicial a essa construção legislativa, evitando-se todas as críticas tecidas ao artigo e dando ao instituto da modificação sua potencialidade máxima, e não jogar os avanços fora e retroceder à sistemática atualmente em vigor.

Já no senado, acolhendo as observações restritivas, a matéria da modificação da demanda passou a ser regida nos seguintes termos: "art. 304. O autor poderá: I - até a citação, modificar o pedido ou a causa de pedir, independentemente do consentimento do réu; I - até o saneamento do processo, com o consentimento do réu, aditar ou alterar o pedido e a causa de pedir, assegurado o contraditório mediante a possibilidade de manifestação deste no prazo mínimo de quinze dias, facultado o requerimento de prova suplementar". Redação, de resto, mantida na íntegra pelo substitutivo da Câmara dos Deputados, havendo tão somente uma alteração tipológica: do posto 304 passou a ocupar agora o posto 330.

Mantendo-se a estrutura intacta, a maneira mais adequada de se interpretar o sistema é dando aos termos causa de pedir e pedido o sentido epistemológico informativo proposto, reconhecendo-se as limitações do ato narrativo e favorecendo, dentro do possível, a aquisição de contornos menos distantes por parte do conjunto enunciativo.

Essas são, em suma, as observações que se tinham para o procedimento comum. Passa-se agora para a análise das ações coletivas.

\section{2 - O processo Coletivo}

\subsubsection{A ação civil pública}


A Lei da Ação Civil Pública previu como objetos mediatos a serem tutelados por essa via os interesses difusos, os coletivos e os individuais homogêneos. Como objeto imediato, o ordenamento jurídico disponibiliza aos co-legitimados todas as espécies de tutelas jurisdicionais existentes. ${ }^{420}$

Conforme se nota, os casos acima descritos envolvem situações de alta complexidade, os quais serão representados no ato introdutório apenas em pequena parte. Ademais, muitos dos legitimados ativos, ao proporem a demanda, não tiveram contato direto com os eventos que compõem a lide.

Pela natureza dos bens envolvidos, bem como pelos escopos do instituto modificativo, as alterações e adições de enunciados fáticos e jurídicos, bem como a possibilidade de formulação de novos pedidos, parece ser medida essencial para a justiça da decisão.

Bloquear a causa de pedir e o pedido no ato introdutório, por tudo que foi exposto, parece ser inconcebível nesse tipo de ação.

\subsubsection{A ação popular}

A ação popular é tida pela Constituição da República como um direito fundamental do indivíduo. Ela se destina, segundo o art. 5 inciso LXXIII, da Carta Magna, "a anular ato lesivo ao patrimônio público ou de entidade de que o Estado participe, à moralidade administrativa, ao meio ambiente e ao patrimônio histórico e cultural" e dispõe que qualquer cidadão é parte legítima para propô-la. Como se nota, seu objeto mediato é bastante abrangente, tendo crescido, como aponta a doutrina, a cada nova regulamentação. ${ }^{421}$

No que toca aos tipos de tutelas que podem ser pleiteadas (objeto imediato), nota-se que o art. 11 da Lei 4.717/65 prevê que a sentença de procedência da ação, além de declarar a invalidade do ato impugnado, condenará o réu ao ressarcimento por perdas e

\footnotetext{
${ }^{420}$ SUSANA HENRIQUES DA COSTA, O processo coletivo na tutela do patrimônio público e da moralidade administrativa. Ação de improbidade administrativa, Ação Civil Pública e Ação Popular, São Paulo, 2009, pp. 162 e ss.

${ }^{421}$ SusAna HENRIQUeS Da Costa, ibidem, pp. 143 e ss.
} 
$\operatorname{danos}^{422}$. Interpretando restritivamente a redação desse dispositivo, parte da doutrina afirmou que "a demanda popular é constitutiva negativa e condenatória" ${ }^{23}$. Saindo dessa estrutura rígida, a visão mais moderna sobre o tema admite a atipicidade dos provimentos. $^{424}$

Ora, a simples leitura das breves linhas acima é suficiente para concluir que: a) os fatos postos à base da demanda serão, na esmagadora maioria das vezes, de natureza complexa; b) o autor, cidadão comum, muitas vezes não teve contato direto com os eventos da demanda, figurando como 'leitor não informado' e possuindo um grau cognitivo bastante escasso; e c) a representação da realidade, embora tenha um grau de subjetividade reduzido pelos próprios escopos da ação, possui um nível de incompletude muito elevado devido a todas as dificuldades narrativas presentes.

Os reais limites da crise e dos acontecimentos, mais do que em qualquer ação individual, vão se delineando com maior precisão ao longo do processo, ressaltando a característica de dinamicidade da causa de pedir.

A norma, tal qual dito anteriormente, é individualizada por meio dos fatos. Logo, também a definição do direito está longe de ser algo estático, mas tem a dinâmica ressaltada, como de resto todas as ações coletivas.

Desse modo, o instituto modificativo deve ser amplamente aceito, sob pena de se relegar aos limites restritivos do ato introdutório a resolução da crise de direito material referente a um direito indisponível.

\subsubsection{A ação de improbidade administrativa}

A ação de improbidade administrativa prevista pela Lei $\mathrm{n}^{\circ} 8.429 / 92$, que buscou regulamentar o dispositivo constitucional do art. $37, \S 4^{\circ}$, tem como objeto mediato a defesa do patrimônio pecuniário do Estado e a probidade administrativa ${ }^{425}$. O primeiro, para fins da citada lei, é constituído pelo patrimônio pertencente à Administração direta,

\footnotetext{
${ }^{422}$ SUSANA, ibidem, p. 151.

423 JosÉ AFONSO DA SILVA, Ação popular constitucional, São Paulo, 1968, p. 108.

${ }^{424}$ SUSANA, O processo coletivo, cit., p. 151-152.

${ }^{425}$ HENRIQUES DA COSTA, ibidem, p. 168.
} 
indireta, fundacional, bem como aquele para o qual o Estado tenha concorrido (art. $1^{\circ}$ ). $\mathrm{O}$ segundo, por seu turno, é uma espécie de moralidade e vem representada, a contrário senso, pelas previsões abstratas contidas nos tipos descritos nos artigos $9^{\circ}, 10^{\circ}$ ou $11^{\circ}$ da LIA.

No que tange ao objeto imediato, porém, tal ação apresenta algumas peculiaridades em relação às demais demandas coletivas. Por ter como objeto a apuração de um ato administrativo e a reposição dos danos ao erário, a estrutura das tutelas é fixa. Tal como faz afirma SUSANA HENRIQUeS DA COSTA, "a sentença de mérito no processo de conhecimento de improbidade administrativa possui uma estrutura fixa. Isto porque, ao julgar tal demanda, o magistrado fará sempre a mesma ordem de raciocínio. De fato, primeiramente o juiz deverá analisar as provas dos autos e decidir se a conduta do agente público é ou não ímproba (tutela cognitiva declaratória). Caso reconheça a improbidade, deverão ser anulados os atos administrativos viciados (tutela cognitiva desconstitutiva) $e$ condenado o agente público ao ressarcimento de eventual dano causado e às demais sanções previstas no art. 12 da Lei no8429/92 (tutela cognitiva condenatória)" ${ }^{206}$

Desse modo, a estrutura das tutelas, em regra, não pode ser alterada pela própria natureza do direito material envolvido. Contudo, isso não significa que o membro do Ministério Público ou a própria administração não possa alterar seus pedidos.

Como a LIA traz tipos cíveis, fundamental que o autor da demanda especifique qual a roupagem que deseja dar aos fatos e apontar quais as penas desejadas. Todavia, por não ter tido contato com os acontecimentos da crise, sua percepção sobre o que realmente aconteceu pode ser distorcida, fazendo, pois, a tipificação equivocada.

Ademais, por se tratarem de fatos que normalmente se protraem no tempo, um enorme background restará do lado de fora dos autos.

Por todas as características dos atos e das posições epistemológicas de seus legitimados diante do conflito, a modificação da demanda, também aqui, parece ser fundamental para a aproximação da representação enunciativa à realidade, dando qualidade à decisão.

${ }^{426}$ Idem, ibidem, p. 170. 


\section{CONCLUSÕES}

Para encerrar o presente trabalho, em apertadíssima síntese, algumas conclusões deverão ser expostas.

1. Buscou-se demonstrar, de início, passando em revista as principais linhas doutrinárias sobre o tema, que as diversas abordagens quanto ao instituto modificativo, por mais variadas que elas sejam, não apresentam soluções satisfatórias para os problemas referentes aos fatos e aos direitos no processo.

Ao que tudo indica, a falta de êxito por parte da doutrina tida aqui por clássica se dá por uma questão de erro de perspectiva. Em linhas gerais, os estudiosos buscam antes de enfrentar o instituto modificativo em si - de resto, antes de encarar diversos outros temas do processo - identificar a demanda, quer pela tradicional formulação dos tria eadem, quer pela ótica do objeto litigioso, ou Streitgegenstand.

2. Independentemente da linhagem alemã ou italiana, os elementos identificadores são utilizados fazendo-se uma simplificação incoerente com a realidade. Os fatos são tratados como elementos naturalísticos e analiticamente definidos, ao passo que o direito é visto como algo homogêneo e facilmente individualizável.

Por esse ângulo, os processualistas afirmam que a causa de pedir consiste no fato e/ou na relação jurídica afirmada, dando a tais institutos um caráter rígido e definitivo já nas primeiras intervenções dos indivíduos.

3. Contudo, se o problema for encarado pela perspectiva epistemológica, vê-se que as manifestações das partes não são fundadas em fatos, mas em enunciados fáticos e jurídicos. Autor, réu e juiz, além dos demais participantes do processo, formulam enunciados relativos aos acontecimentos que estão à base do conflito. Mais do que uma mera questão terminológica, a análise partindo-se desse ponto de vista coloca luz em alguns elementos fundamentais. São eles: 
a) a atividade enunciativa nada mais é que uma narração; b) sendo uma narração, inúmeras são as limitações representativas dos enunciados em relação aos fatos, seus objetos; c) vários são os possíveis enunciados fáticos verdadeiros sobre um mesmo evento, da mesma maneira que vários poderão ser os enunciados falsos; d) os enunciados são frutos de uma interpretação subjetiva do indivíduo os narra; e) as asserções feitas no âmbito do processo são formuladas por sujeitos envolvidos, que recortam a realidade conforme seus interesses na demanda, escondendo acontecimentos que os prejudicam e destacando os que lhes favorecem; f) além de incompletos, eles, os fatos, são selecionados de acordo com uma norma subjetivamente eleita em estruturação de tese jurídica direcionada à proteção dos interesses privados de uma das partes; e g) todos esses enunciados são meramente hipotéticos.

4. Conforme facilmente se nota, a atividade de construção de uma petição inicial é algo extremamente variável, podendo ser alterada, inclusive, se feita pelo mesmo advogado em dois momentos distintos.

5. Por essas características, em regra, esquecidas pela simplificação da doutrina clássica, é que tamanhas variedades da realidade não são enquadráveis com facilidade em conceitos abstratos e rígidos como o de causa de pedir e pedido. Dessa maneira, a metodologia identificativa fica comprometida, devendo-se, pois, abandoná-la.

6. Ademais, há no raciocino identificativo premissas silogísticas inaceitáveis, responsáveis pelo enclausuramento dos limites da demanda no ato introdutório. Contudo, como visto, a decisão é fruto de um processo complexo denominado juízo de fato e de direito, sendo a subsunção da premissa menor na premissa maior apenas e tão somente um iter daquele procedimento.

7. O juízo de fato se dá por meio de um fluxo de conhecimento não contínuo, porém extremamente dinâmico, que se desenvolve ao longo de todo o processo. De um estado epistêmico cognitivo ao outro, o juiz vai formando sua concepção sobre o litígio conforme vão sendo aportados inputs probatórios. Logo, os limites da crise não são estipulados na 
inicial, por meio dos ditos elementos objetivos da demanda, mas sim vão ganhando forma durante $\mathrm{o}$ arco procedimental.

8. O juízo de direito, ou individualização e interpretação da norma aplicável ao caso concreto, também não se dá de forma estática. Paralelo ao processo do juízo de fato, a escolha da roupagem jurídica que irá recobrir os fatos da causa acontece conforme explica a teoria circular hermenêutica, a qual aponta para vários pontos de intersecção entre a construção das premissas maiores e menores.

9. Tomando como requisito de justiça da decisão a verdade e a correta aplicação da lei, chega-se à correlação entre demanda correta/resposta correta. Em outros termos, para que se tenha uma sentença justa, fundamental que o desideratum da demanda esteja bastante delimitado. Ocorre, porém, que, segundo se viu inicialmente, os atos das partes são parciais, subjetivos, incompletos e potencialmente falsos, características divergentes dos cânones de justiça.

10. Desse modo, podem-se encarar as modificações dos enunciados fáticos e de direito, bem como as alterações de pedidos, por um ângulo diferente, dando a elas um novo escopo dentro do processo: atribuir ao conjunto representativo formulado pelas partes maior coesão com a realidade, possibilitando assim uma sentença com melhor qualidade.

11. Diante de uma visão instrumental do processo, método pelo qual se busca uma pacificação social com justiça, dar potencialidade ao instituto da modificação parece ser algo de fundamental importância. 


\section{BILIOGRAFIA}

Alvaro de Oliveira, Do Formalismo no Processo Civil - proposta de um formalismovalorativo, São Paulo, 2010.

Auletta, Ancora sul mutamento della domanda di esecuzione in domanda di risoluzione, in Giur. It., 1950, I, 2, pp. 661-664.

BARbosa Moreira, Considerações sobre a causa de pedir na ação rescisória, in Temas de Direito Processual, 4ª Série, São Paulo, 1989.

Barbosa Moreira, Questões Velhas e Novas em Matéria de Classificação das Sentenças in Temas de Direito Processual - $8^{\mathrm{a}}$ série, São Paulo, 2004.

BARbosa Moreira, Correlação entre pedido e a sentença, in, Repro, 1996, n. 83, pp. 207 e ss..

BeDaque, Direito e Processo, cit., p. 11

BEDAQUe, Poderes Instrutórios do Juiz, São Paulo, 2009.

Bellavitis, L’identificazione delle azioni, Padova, 1924.

Berzosa Francos, Demanda, 'causa petendi' y objeto del proceso, Salamanca, 1984.

BETTI, Ragione e azione, in Riv. dir. proc. civ., 1932, I, pp. 203 e ss.

Botelho De Mesquita, A causa petendi nas ações reivindicatórias, in Ajuris, 1980, pp. 166 e ss.

BüLOw, La teoría de las excepciones y los presupuestos procesales, Miguel Angel Rosas Lichtschein (trad.), Buenos Aires, 1964.

CAlamandrei, Il concetto di 'lite' nel pensiero di Francesco Carnelutti, in Rev. dir. proc. civ., 1928, pp. 3-22 (versão em espanhol El concepto di 'litis' em el pensamiento di F. Carnelutti, in Estudios sobre el proceso civil, Sentís Melendo (trad.), Buenos Aires, 1945, p. 265-294), 
Calmon de Passos, Causa de pedir, in Enciclopédia Saraiva do Direito, v. XIV, São Paulo, 1983.

CANOVA, La domanda giudiziale e il suo contenuto, in Commentario al c.p.c. diretto da E. Allorio, livro II, tomo I, Torino, 1980, pp. 3-234.

CARnElutTI, Diritto e processo, Napoli, 1958.

CARnelutTI, Instituciones del proceso civil, Sentís Melendo (trad.), Buenos Aires, 1950, vol. I, p. 28.

Carnelutti, Lezioni di Diritto Processuale Civile, Padova, 1931, v. I, p. 3.

CARNELUTTI, Lite e funzione processuale, in Riv. dir. proc. civ. 1928, p. 29

CARRATA, Il principio della non contestazione nel processo civile, Milano, 1995.

CARrilho Lopes, Limites Objetivos e Eficácia Preclusiva da Coisa Julgada, São Paulo, 2012.

Cataudella, Fattispecie e fatto. I. Fattispecie (voce), Enc. dir., vol. XIV, Milão, 1967, pp. 926-941;

CAVAllini, L'eccezione 'nuova' rilevabile d'ufficio nel giudizio d'appello riformativo, in Riv. dri. proc., 2014, n. 3, pp. 588 e ss..

Celso Agrícola Barbi, Comentários ao Código de Processo Civil, Rio de Janeiro, 1975.

Celso AgRícola BARBI, Da preclusão no processo civil, in Revista Forense, n. 158, 1955, pp. 59 e ss.

CENTONZE, Scienza 'spazzatura' e scienza 'corrotta' nella attestazioni e valutazioni dei consulenti tecnici nel processo penale, in Riv. it. dir. proc. pen., 2001, pp. 1232 e ss.

ChIARLONI, Questioni rilevabili d'ufficio, diritto di difesa e 'formalismo delle garanzie', in Riv. trim. dir. proc. civ., 1987, p. 569 e ss.; CivinInI, Poteri del giudice e delle parti, cit., pp. 1 e ss.; 
CHIOVENDA, Identificazione delle azioni. Sulla regola 'ne eat iudex ultra petita partium', in Saggi di diritto processuale civile, v. I, Milão, 1993, pp. 157-177.

Chiovenda, Principios de derecho procesal civil, Jose Casáis y Santaló (trad.), tomo II, Madri, 1925.

Cintra, Dinamarco e Grinover, Teoria Geral do Processo, São Paulo, 2000. pp. 260261.

CIPRIANI, L'autoritarismo processuale e le prove documentali, in Il Giusto Processo, I, Jan-Mar, 2007, pp. 289 e ss

CIPRIANI, L'avvocato e la verità, in Yarshell e Moraes (coord.), Estudos em homenagem à professora Ada Pellegrini Grinover, São Paulo, 2005, pp. 821-826.

Civinini, Poteri del giudice e delle parti nel processo ordinario di cognizione. Rilevo ufficioso delle questioni e contraddittorio, in Foro it., parte V, p. 7.

Claudia CAFFI, Illocuzione, metacomunicazione, coinvolgimento. Problemi teorici di pragmatica linguistica, Pavia, 1990, p. 12.

COlOMA CORREA, Vamos a contar mentiras tralará..., $O$ de límite a los dichos de los abogados, in Rev. de Derecho, Universidad Austral de Chile, XIX, n. 2, 2006, pp. 27-52.

Comoglio, Ferri, TARUfFo, Lezioni sul processo civile, Bologna, 2011, v. I, p. 297 e ss.

Comoglio, La Garanzia Constituzionale della Azione ed il Processo Civile, Padova, 1970.

Consolo, Mutatio libelli: l'accettazione tácita o presunta e l'eccezione di domanda nuova, ovvero di un costruto giurisprudenziale incoerente, in Rev. dir. proc., 1990, pp. 620 e ss.

CorReia de MendonçA, Virus autoritario e processo civil, in Il Giusto Processo Civile, I, Jan-Mar, 2008, pp. 115 e ss.

CORSINI, Rilevabilità di ufficio della nullità contrattuale, principio della domanda e poteri del giudice, in Riv. dir. civ., 2004, pp. 667 e ss.; 
Costanzo M. CEa, Le nuove prove in appello, in Giusto Processo Civile, n. 3, 2006, pp. 103 e ss.

CRUZ E TUCCI, A causa petendi no processo civil brasileiro, São Paulo, 2001.

CRUZ E TUCCI, A causa petendi na ação reivindicatória, in Ajuris, 1997, pp. 184 e ss.

CRUZ E TUCCI, A denominada 'situação substancial' como objeto do processo na obra de Fazzalari, in Repro, 1992, n. 68, pp. 271 e ss.

CSABA VARGAS, The mental transformation of facts into a case, in ARSP, 1991, pp. $58 \mathrm{e}$ ss.

Csaba VARga, The Non-cognitive Character of the Judicial Establishment of Facts, in Legal System and Practical Reason, n. 15. Stutgart, 1991, ed. Hans-Joachim Koch \& Ulfrid Neumann (Stuttgart: Franz Steiner Verlag Stuttgart 1994), pp. 230-239.

D'ANGELO, In tema di 'mutatio libelli' nel giudizio di primo grado, in Foro It., 1972, I, pp. 3470-3471.

DegensZAJ, Alteração dos fatos no curso do processo, 2010, em dissertação de mestrado em direito, Faculdade de Direito da Universidade de São Paulo.

DENTI, Questioni rilevabili d'ufficio e contraddittorio, in Riv. dir. proc., 1968, pp. 217 e ss.; GRASSO, La pronuncia d'ufficio, Milano, 1967, pp. 43 e ss.;

DERRIDA, Of Grammatology, Gayatri Chakravorty Spivak (trad.), Baltimore, 1997.

Dinamarco, Instituições de Direito Processual Civil, v. II, São Paulo, 2009.

Dinamarco, Instituições de Direito Processual Civil, v. III, São Paulo, 2009.

DinAMARCO, Instrumentalidade do processo, São Paulo, 2009.

DINAMARCO, Ônus de afirmar e causa petendi - Os documentos indispensáveis à propositura da demanda - Ônus de afirmar e ônus de impugnação específica (CPC, art. 302) - Pedido determinado e sentença líquida - Confissões de dívida como declarações de vontade constitutivas - Honorários advocatícios, in Revista Forense, Rio de Janeiro, jan/mar 1998, p. 234. 
Dinamarco, O Princípio do Contraditório e sua Dupla Destinação, in Fundamentos do Processo Civil Moderno, v. I, São Paulo, 2010.

DRETSKE, Knowledge and the Flow of Information, Cambridge, Mass., 1981.

EDUARDO GRASSO, La regola della corrispondenza tra il chiesto e il pronunciato e la nullità da ultra e da extrapetizione, in Riv. dir. proc., 1965, pp. 387 e ss.

ELIAS, Coinvolgimento e distacco. Saggi di sociologia della conoscenza, Bologna, 1988, pp. 89-143.

ENRIQUES, Do Corporate Law Judges Matter? Some Evidence from Milan, in European Business Organization Law Review, 2002, pp. 765 e ss..

ENRIQUES, Il nuovo diritto societario nelle mani dei giudici: una ricognizione empirica, in Stato e mercato, 2001, I, pp. 79 e ss..

ESSER, Precomprensione e scelta del método nel processo di individuazione del diritto, traduzione Salvatore Patti e Giuseppe Zaccaria, Napoli, 1983.

Everaldo De Souza, Do princípio da eventualidade no sistema do Código de Processo Civil, in Revista Forense, n. 251, 1975, pp. 101 e ss.

FAiren Guillén, La transformación de la demanda en el proceso civil, Santiago de Compostela, 1949.

FALZEA, Accertamento in Enc. dir., vol. I, Milano, 1968, pp. 206 e ss.

FALZEA, Fattispecie e fatto. II. Fatto giuridico (voce), Enc. dir., vol. XVI, 1967, pp. 941950.

FARber e SHERry, Telling Stories Out of School. An Essay on Legal Narratives, in 45 Stanford Law Review, 1993, pp. 807 e ss.

FAZZALARI, Istituzioni di Diritto Processuale, Padova, 1989.

FAZZALARI, La giurisdizione volontari - Profilo sistemático, Padua, 1953. 
FERRARA, Mutamento di domanda giudiziale e conversione di negozio processuale, in For. It., LXVI, 1941, pp. 624 e ss.

FLACH, Alteração da demanda, 2013, em dissertação de mestrado em direito, Faculdade de Direito da Universidade Federal do Rio Grande do Sul.

FRANÇA e ADAMEK, Affectio societatis: um conceito jurídico superado no moderno direito societário pelo conceito de fim social, in Revista de Direito Mercantil Industrial, Econômico e Financeiro, 2008, v. 149-150, pp. 108 e ss..

FREDIE DIDIER JR., Os três modelos de direito processual: inquisitivo, dispositivo e cooperativo, in Repro, 2005, n. 127, p. 75 e ss.

Galeno Lacerda, Despacho saneador, Porto Alegre, 1953.

GamBA, Diritto societario e ruolo del giudice, Padova, 2008.

Gamba, Domande senza risposta. Studi sulla modificazione della domanda nel processo civile, Padova, 2008.

GäRDENFORS, Knowledge in flux: modeling the dynamics of epistemic states, Cambridge, 1988

GIANFRANCO RICCI, Questioni controverse in tema di onere della prova, in Riv. dir. proc., 2014, n.2, pp.321 e ss..

GIANFRANCO RICCI, 'Individuazione' o 'sostanziazione’ nella riforma del processo civile, in Riv. trim. dir. proc. civ., 1995, pp. 1227 e ss.

GIANNOZZI, La modificazione della domanda nel processo civile, Milão, 1958, pp. 35 e ss.

GiannOZZI., Sul mutamento di 'causa petendi', in Gir. It., parte I, Sez. II, 1964, pp. 719 e ss.

GIORGETTI, Il principio di variabilità nell'oggetto del giudizio, Turim, 2008.

Goffredo Telles Junior, Iniciação na Ciência do Direito, São Paulo, 2006, p. 31. 
HabscheId, L'oggetto del Processo nel Diritto Processuale Civile Tedesco, Angela Loaldi (trad.), in Riv. dir. proc., 1980, pp. 454 e ss.

HeInItIZ, Considerazioni attuali sui limiti oggettivi del giudicato, in Giur. It., 1955, parte I, pp. 755 e ss.

HeINITZ, I limiti oggettivi della cosa giudicata, Padova, 1937.

IRTI, Rilevanza giuridica (voce), in Noviss. Dig. It., vol. XV, Torino, 1957, pp. 1094-1112;

IRTI, La crisi della fattispecie, in Rev. dir. proc., 2014, II, pp. 36 e ss..

JaAKKo HintiKKa e Merril B. HintiKKA, Sherlock Holmes e la lógica moderna: verso una teorizzazione della ricerca di formazione attraverso domende, Giampaolo Proni (trad.), in Eco, Sabeok (a cura di), Milão, 2000, pp. 185 e ss..

JEROME FrAnK, Law and the Modern Mind, Nova York., 1930.

Jerome Frank, What Courts Do in Fact, in Illinois Law Review 26, I, 1932, pp. 645 e ss;

JoLOwICZ, The parties, the judge and the facts of the case, in Studi in Onore di Vottorio Denti, v. II, Padova, 1994, pp. 233 e ss.

José AfONSO DA Silva, Ação popular constitucional, São Paulo, 1968.

JuAn Montero Aroca, El proceso civil llamado 'social' como instrumento de 'justicia' autoritaria, in ID (coord), Proceso civil e ideologia. Un prefacio, una sentencia, dos cartas y quince ensayos, Valencia, 2006, pp. 141-144.

Junior AleXandre Moreira Pinto, A causa petendi e o contraditório, São Paulo, 2007, pp. 17 e ss.

JunQUEIRA DE AZEVEDo, Negócio jurídico - existência, validade e eficácia, São Paulo, 2002, pp. 1-22.

KAMINKER, Reflexiones sobre hechos, pruebas, abogados y jueces, in Rev. Peruana de Derecho Procesal, jun/2002, pp. 130-133. 
KARIM TRINDADE e STRECK (coord.), Direito e literatura: da realidade da ficção à ficção da realidade, São Paulo, 2013, passim.

Kaufmann, Diritto e linguaggio, in Filosofia del diritto ed ermeneutica, a cura di Marino, Milano, 2003, pp. 175 e ss.

KAUFMAnN, Sulla circolarità nell'individuazione del diritto, in Filosofia del diritto ed ermeneutica, Milano, 2003, pp. 115 e ss.

KELSEN, Teoria pura do direito, João Baptista Machado (trad.), São Paulo, 1999.

KINIJNIK, O recurso especial e a revisão de fato pelo superior tribunal de justiça, Rio de Janeiro, 2005.

LAZZARO, Diritto e linguaggio comune, in Riv. trim. proc. civ., 1981, p. 140.

Lent. Diritto Processuale Civile Tedesco. Il Procedimento di Cognizione, Edoardo Ricci (trad.), Nápoles, 1962.

LeOnel, Causa de Pedir e Pedido - O Direito Superveniente, São Paulo, 2006.

Liebman, Eficácia e Autoridade da Sentença, Alfredo Buzaid e Benvindo Aires (trad.), Rio de Janeiro, 1984.

LuHMANN, Legitimação pelo procedimento, Maria da Conceição Côrte-Real (trad.), Brasília, 1980.

LUISO, La nuova fase introduttiva del processo di separazione e diverzio, in Il giusto processo civile, ano 1, n. 3, 2006, pp. 41 e ss, especificamente sobre o ponto, p. 47.

LUISO, Questione rilevata di ufficio e contraddittorio: uma sentenza 'rivoluzionaria'?, in Giust. civ., 2002, pp. 1612-1615.

MAGnONE, Sui limiti temporali della proponibilità di eccezioni nuove in appello, in Riv. dir. proc., 1978, pp. 119 e ss..

MAIORCA, Fatto giuridico - fattispecie (voce), in Noviss. Dig. It., vol. VII, Torino, 1957, pp. 111-133; 
Mandrioli. Corso di Diritto Processuale Civile, Torino, 1989.

MANDRIOLI, Riflessioni in tema di 'petitum' e di 'causa petendi', in Rev. dir. proc., 1984, 3, pp. 465 e ss

MARINONI, Da teoria da relação jurídica processual ao processo civil do estado constitucional, acessado in http://www.abdpc.org.br/abdpc/artigos/Luiz\%20G\%20Marinoni(8)\%20-\%20formatado.pdf

MARINONI. Teoria Geral do Processo, v. I. São Paulo, 2011.

MARTíneZ MARTíneZ, Literatura y derecho, Ciudad de Mexico, 2010, passim.

MERRYMAn, Lo 'stile italiano',,: l'interpretazione, in Riv. trim. dir. proc. civ., 1968, pp. 373 e ss.

Milton Paulo de Carvalho, Do pedido no processo civil, Porto Alegre, 1992.

Milton Paulo de Carvalho, Pedido novo e aditamento do pedido. O art. 294 do Código de Processo Civil na sua nova redação, in Cruz e Tucci (coord.), Processo Civil Evolução - Vinte anos de vigência, São Paulo, 1995, p. 174 e ss.

MicheLI, Jura novit curia, Riv. dir. proc., 1961, pp. 575 e ss.

MindA, Postmodern Legal Movements. Law and Jurisprudence at the Century's End, New York-London, 1995, p. 161.

Moniz de Aragão, Comentários ao Código de Processo Civil, v. II, Rio de Janeiro, 1983.

Montesano, Dirito sostanziale e processo, in Riv. Trim. Dir. Proc. Civ., 1993, pp. 63 e Ss.;

MONTESANO, Invocazione per la prima volta in appello dell'usucapione a fondamento di um'azione di revindica. Osservazioni in tema di "jus novorum" e di mutamento di "causa petendi” in appello, in Giur. Compl. Cass. Civ., 1948, I, pp. 112 e ss..

MonteSAnO, Limiti oggettivi di giudicato su negozi invalidi, in Riv. Dir. Proc., 1991, p. 60 e ss.; 
MoReira SANTOS, A estabilização objetiva da demanda no direito brasileiro, 2014, dissertação de mestrado em direito, Faculdade de Direito da Universidade de São Paulo.

Mosco, Azione per adempimento e azione di risoluzione per inadempimento, in Foro It., I, 1951, pp. 1280-1282.

NALINI, Ética Geral e Profissional. São Paulo, 2009

Oliva Santos, Disponibilidad del objeto, conformidad del imputado y vinculación del Tribunal a las pretenciones em el proceso penal, in (estrato) Revista General de Derecho, Out-Nov, 1992, pp. 9854-9903

ORLANDo Gomes, Obrigações, Rio de Janeiro: Forense, 2008.

ORMAZABAL SÁNCHEZ, Iura novit curia, Barcelona-Madrid, 2007.

Pellegrini Grinover, O Processo em Evolução, Rio de Janeiro, 1996.

PICó JUNOY, Iudex iudicare debet secundum allegata et probata, non secundum conscientiam: storia della erronea citazione di un brocardo nella dottrina tedesca $e$ italiana, in Riv. dir. proc., 2007, pp. 1497 e ss.

PiCo I JunOY, Modificación de la demanda, Valencia, 2006.

Pontes De Miranda, Comentários ao Código de Processo Civil, tomo II, Rio de Janeiro, 1947.

Proto PisAni, I Diritti e le Tutele, Napoli, 2008.

Puoli, Poderes do Juiz e as Reformas do Processo Civil, São Paulo, 2002.

PutnaM, Razón, verdad y historia, Jose Miguel Esteban (trad.), Madrid, 1988, pp. 132.

Recena Costa, Superior Tribunal de Justiça e recurso especial: análise da função e reconstrução dogmática, 2011, em dissertação de mestrado em direito, Faculdade de Direito da Universidade de São Paulo.

RenZo CAVAnI, 'Decisão Justa': mero slogan?, in RePro, v. 236, 2014, p. 119 e ss 
Rosemberg, Tratado de Derecho Procesal Civil, v. II, Angela Romera Vera (trad.), Buenos Aires, 1955.

ROTA, I fatti non contestati e il nuovo art. 115, in TARUFFO (diretto da), Il processo civile riformato, Bolonha, 2014, pp. 181 e ss.

RotA, Dalla domanda di adempimento alla domanda di risoluzione, in Riv. dir. proc., 1990, pp. 876 e ss.

Salvatore SatTA, Spunti per una teoria della domanda, in Soliloqui e Colloqui di un Giurista, Padova, 1968, pp. 327 e ss.

SANCHIS CRESPO, Aproximación a la prueba en el nuevo proceso civil español, in Rev. Peruana de Derecho Procesal, jun/2002, p. 271.

SARTOR, Studi di lógica giuridica, Firenze, 1993, (edição provisória).

SCHERMI, In tema di mutatio ed emendatio e di notifica delle domande nuove al contumace, in Giust. civ., parte I, 1960, pp. 2124 e ss.

SCHWAB, Objeto Litigioso, cit., p. 251;

SEARle, Speech Acts: An Essay in the Philosophy of Language, Cambridge, 1969, tradi esp.: Actos de habla, Ensayos de filosofia del linguaje, Luis M. Valdés Villanueva (trad.), Barcelona, 1994, pp. 22 e ss..

SEnTís MeLENDO, El juez y el derecho (Iura novit curia), Buenos Aires, 1957.

SICA, Preclusão processual civil, São Paulo, 2008.

Silva Pereira, Instituições de Direito Civil, I, Rio de Janeiro, 2008.

STEIN, El conocimiento privado del juez, tradução ANDRÉS DE LA Oliva SANTOS, Madrid, 1990.

SUSANA HENRIQUES DA COSTA, O processo coletivo na tutela do patrimônio público e da moralidade administrativa. Ação de improbidade administrativa, Ação Civil Pública e Ação Popular, São Paulo, 2009. 
TARUFFo, Considerazioni su prova e verità, in Sui Confini, Bolonha, 2002, p. 277 e ss.

TARUFFo, Elementi per un'analisi del giudizio di fatto, in Sui Confini, Bologna, 2002, p. 240 e ss..

TARUFFo, Idee per una teoria della decisione giusta, in Sui Confini, Bolonha, 2002, pp. 226 e ss..

TARUFFO, Il vertice ambíguo. Saggi sulla cassazione civile, Bologna, 1991.

TARUFFO, La motivación de la sentencia civil, Madrid, 2011, pp. 151-168.

TARUFFO, La prova scientifica nel processo civile, in (estratto) Riv. trim. dir. proc. civ., 2005, pp. 1079 e ss.

TARUfFO, La prueba de los hechos, Ferrer Beltrán (trad.), Madrid, 2005, pp. 96-105 e 119128 ;

TARUFFO, La semplice verità. Il giudice e la costruzione dei fatti, Bari, 2009, pp. 36 e ss.,

TARUFFO, La trattazione della causa, in TARUFFO (a cura di), Le riforme della giustizia civile, Torino, 2000, sec. ed., p 301.

TARUFFO, Legalità e giustificazione della crezione giudiziaria del diritto, in (estratto) Riv. Trim. Dir. Proc. Civ., 2001, pp. 11 e ss.

TARUFFO, L'integrazione dell'art. 101 C.P.C., il contraddittorio sulle questioni rilevate d'ufficio e la 'scommessa aperta' dell'ordinamento processuale, in TARUFFO (diretto da), Il processo riformato, Bologna, 2010, pp. 65-179;

TARUfFo, Poteri probatori delle parti e del giudice in Europa, in (stratto) Riv. trim. dir. proc. civ., 2006, pp. 451 e ss.

TARufFo, Preclusioni (diritto processuale civile) (voce), in (stratto) Enc. dir., Agg. I, Milão, 1997, pp. 974 e ss.

TARufFo, Processo civil e litigiosità, in (estratto) Scritti in Onore di Mario Vellani, tomo II, pp. 803 e ss. 
TARUFF, Prova (in generale), in (estratto) Digesto, vol. XVI civile, 1997, p. 4.

TARuffo, Prova giuridica, in (estratto) Enc. dir., Annali, vol. I, Milano, 2007, pp. 1016 e SS.

TARUFFo, Prova scientifica (diritto processuale civile), in (estratto) Enc. Dir., annali II, I, pp. 965 e ss.;

TARUFFO, Senso comune, esperienza e scienza nel ragionamento del giudice, in (estratto) Riv. trim. dir. proc. civ., 2001, pp. 665 e ss.

TARUFFO, Sulla complessità della decisione giudiziaria, in Psicologia culturale, 2013, n. 3, pp. 29 e ss.

TesheINER, Elementos da ação, in Revista Ajuris, Porto Alegre, nov. 1994, pp. 108 -135, visto em http://www.abdpc.org.br/abdpc/artigos/Jos\%C3\%A9\%20M\%20Tesheiner(5)\%20formatado.pdf

TheOdORO Junior, Curso de direito processual civil, III, Rio de Janeiro, 2000

TORALDO DI FRANCIA, Le cose e i loro nomi, Bari, 1986, pp. 27 e ss.

TwINING, Rethinking Evidence, Exploratory Essays, Cambridge, 2006, p. 336.

Vullo, Le sezioni unite si pronunciano in tema di inammissibilità della domanda nuova, rilevabilità d'ufficio del vizio e accettazione del conttraditorio, in Giur. It., 1996, I, 1, pp. 1440-1452.

WRÓBLEWSKI, Ideologia de la aplicación judicial del derecho, Géssie Fontus (trad.), Instituto de investigaciones jurídicas de la Unam, 1992, pp. 19 e ss.

WRÓBLEWSKI, Legal language and legal interpretation, in Law and Philosophy, n. 4, 1985, pp. 240-241.

YARSHELL, Antecipação da prova sem o requisito da urgência e direito autônomo à prova, São Paulo, 2009, p. 65 e ss.

YARSHELl, Tutela jurisdicional, São Paulo, 2006. 
ZACCARIA, 'Precomprensione' e controlli di razionalità nella prassi del giudice, in Riv. dir. civ. 1984, parte II, pp. 313 e ss.

ZANZUCCHI, Nuove domande, nuove eccezioni e nuove prove in appello, Milão, 1916. 